Plant Spores and Other

Microfossils From Upper

Devonian and Lower

Mississippian Rocks of Ohio

GEOLOGIGAL SURVEY PROFESIONAL PAPER 364 


\section{Plant Spores and Other}

Microfossils From Upper

Devonian and Lower

Mississippian Rocks of Ohio

By MARCIA R. WINSLOW

GEOLOGICAL SURVEY PROFESSIONAL PAPER 364

Stratigraphic occurrence, systematic classification, and illustration of plant microfossils

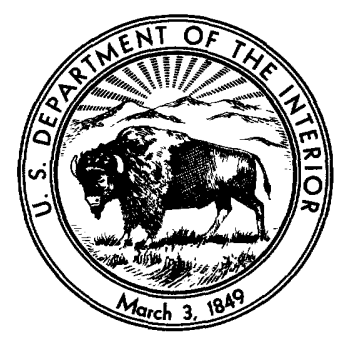




\section{UNITED STATES DEPARTMENT OF THE INTERIOR}

STEWART L. UDALL, Secretary

GEOLOGICAL SURVEY

Thomas B. Nolan, Director

For sale by the Superintendent of Documents, U.S. Government Printing Office

Washington 25, D.C. 


\section{CONTENTS}

Abstract

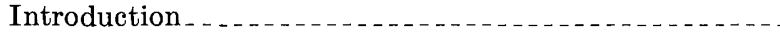

Microfossil assemblages and their geological and botanical significance..........................

Nature of present problem

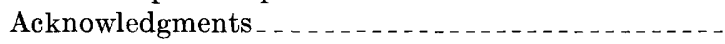

Review of previous studies.......

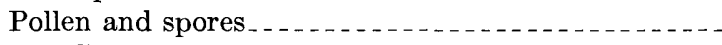

General history

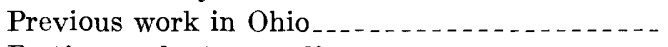

Pertinent plant-spore literature

Foerstians and larger.plant fossils......

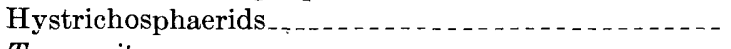

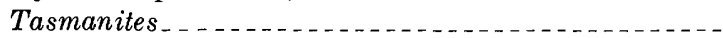

Plant spore morphology and classification.............

Morphology, symmetry, orientation, and form

Haptotypic and emphytic characters.............

Nomenclatural and taxonomic treatment........

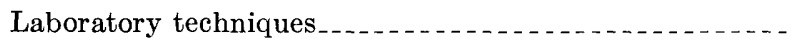

Sample examination

Maceration procedures . . .

Preparation of residues for mounting ............

Microscopic examination and illustration .........

Stratigraphic relations and sample localities...........

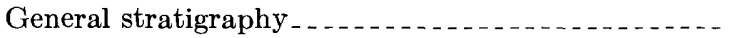

Middle Devonian strata...................

Upper Devonian strata. ......................

Mississippian strata........................

Sampling localities.........

Locality 1 . . . . . .

Locality $2 \ldots \ldots$

Locality $3 \ldots \ldots$

Locality 4

Locality $5 \ldots$

Locality 6

Locality 7 .

Locality 8.

Locality 9

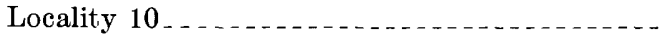

Miscellaneous samples.

Microfossil occurrence and distribution

Stratigraphic occurrence

Middle Devonian strata

Upper Devonian strata........

Lower Mississippian strata

General nature of floras . . . . . . . . .

Review of megafossil evidence............

Interpretation based on microfossils . . . . . . . . .

Summary

Page
1
2
2
3
5
5
5
5
6
6
7
8
8
8
8
9
10
10
10
11
11
11
12
12
12
12
13
13
13
15
15
15
16
16
17
19
20
21
21
21
21
21
22
24
25
25
26
27

Systematic descriptions

Genus Triletes (Bennie and Kidston, 1886)

ex Zerndt, 1930

Triletes auritulus n. $\mathrm{sp} \ldots \ldots$

Triletes catenulatus n. $\mathrm{sp} \ldots \ldots . . . . . . . . . . . .31$

Triletes catenulatus var. marginatus $\mathrm{n}$. var $-{ }_{-}$

Triletes catenulatus var. mixtus n. var.... 33

Triletes cervicornis n. sp................ 34

Triletes variabilis $\mathrm{n}$. $\mathrm{sp}_{\text {................. }} 34$

Triletes triquetrus $\mathrm{n} . \mathrm{sp} \ldots \ldots \ldots$

Triletes globulus n. sp................ 36

Triletes aries $\mathrm{n} . \mathrm{sp} \ldots \ldots$

Triletes sp. A._._._._._. 38

Triletes? sp. B..................... 38

Triletes spp.

Genus Lycospora Schopf, Wilson, and Bentall,

$1944 \ldots \ldots$

Lycospora? sp. A

Genus Cirratriradites Wilson and Coe, 1940_... 41

Cirratriradites hystricosus n. sp......... 41

Cirratriradites sp. A._............ 42

Cirratriradites sp. B................. 42

Genus Endosporites Wilson and Coe, 1940_.... 42

Endosporites chagrinensis n. sp......... 43

Endosporites lacunosus n. sp_._._._..... 44

Endosporites sp. A

Endosporites sp. B $\ldots$

Endosporites? pseudoradiatus n. sp..._._. $\quad 45$

Endosporites? crassaspinosus n. sp........ 47

Endosporites? sp

Genus Densosporites (Berry) Schopf, Wilson, and

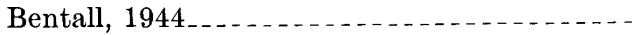

Densosporites sp. A

Densosporites? sp. B

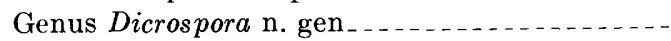

Dicrospora porcata n. sp..............

Dicrospora amherstensis n. sp...........

Dicrospora bedfordi $\mathrm{n} . \mathrm{sp}$

Dicrospora multifurcata $\mathrm{n} . \mathrm{sp} \ldots$

Dicrospora multifurcata var. impensa n. var-

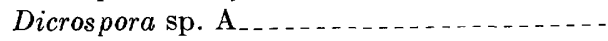

Dicrospora sp. B.......................

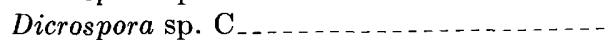

Dicrospora spp. .........................

Genus Calamospora Schopf, Wilson, and Ben-

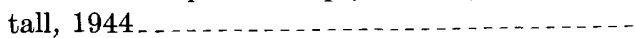

Calamospora obtecta n. sp............

Calamospora obtecta?

Calamospora sp. A. .......................

III 
Systematic descriptions-Continued

Plant kingdom-Continued

Genus Reticulatisporites (Ibrahim) Schopf, Wil-

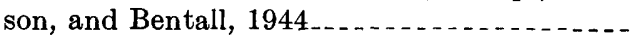

Reticulatisporites crassus n. sp...........

Reticulatisporites? fimbriatus n. sp.........

Reticulatisporites? fimbriatus var. spathu-

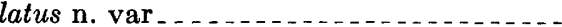

Reticulatisporites? spp................

Genus Punctatisporites (Ibrahim) Schopf, Wil-

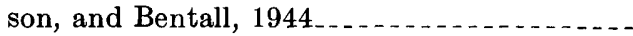

Punctatisporites ef. $P$. nitidus Hoffmeister, Staplin, and Malloy, 1955_........

Punctatisporites sp. A...............

Punctatisporites sp. B................

Punctatisporites? logani n. sp...........

Punctatisporites? sp. C

Genus Granulatisporites (Ibrahim) Schopf, Wil-

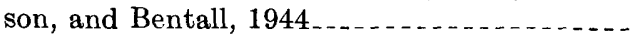

Granulatisporites logani $\mathrm{n} . \mathrm{sp} \ldots . . . . . . . .$.

Genus Verrucosisporites (Ibrahim) Potonié and

Kremp, 1954...............................

Verrucosisporites depressus n. sp. ........

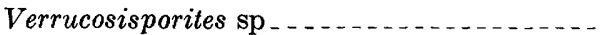

Verrucosisporites? sp. A...............

Genus Anapiculatisporites Potonié and Kremp, 1954

Anapiculatisporites? retusus $\mathrm{n} . \mathrm{sp}$

Genus Callixylon Zalessky, 1911............ Callixylon sp.

Genus Spermatites Miner, 1935 Spermatites $\mathrm{sp}$

Unidentified vascular fragments .

Genus Laevigatosporites (Ibrahim) Schopf, Wilson, and Bentall, 1944

Laevigatosporites $\mathrm{spp}$

Genus Grandispora Hoffmeister, Staplin, and Malloy, 1955

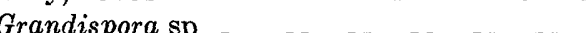

Genus Cyrtospora n. gen.

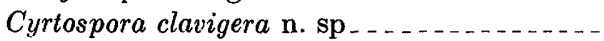

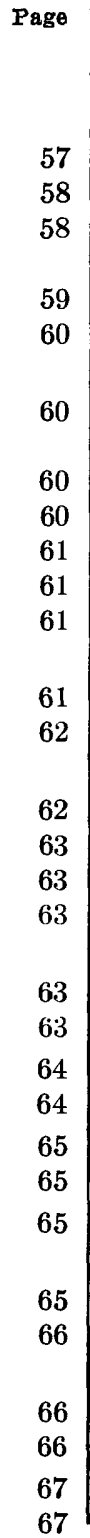

Systematic descriptions-Continued

Plant kingdom-Continued

Genus Canthospora n. gen

Canthospora patula n. sp.......... 68

Canthospora cracens n. sp _........... 69

Canthospora spp.................. 70

Canthospora? sp..................... 70

Genus Convolutispora Hoffmeister, Staplin, and Malloy, 1955

Convolutispora tuberosa $\mathrm{n} . \mathrm{sp}$

Convolutispora sp. A...................

Convolutispora sp.......................

Genus Radforthia n. gen ..................... Radforthia radiata n. sp...................

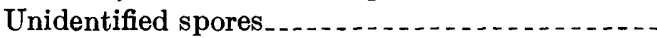
Spore type $A_{1}$

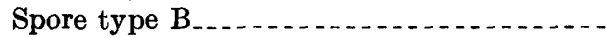

Spore type $\mathrm{C}_{\ldots} \ldots \ldots \ldots$

Spore type D $D$

Unidentified dermal and subdermal structures . -

Sclerenchymatous "nests" ...............

Kingdom uncertain . . . . . .

Hystrichosphaerids....... . . . . . . . . . . . . . . 74

Genus Hystrichosphaeridium Deflandre, 1937_. $\quad 75$

Hystrichosphaeridium trispinosum Eisenack, 1938...... 75

Hystrichosphaeridium of. H. longispinosum (Eisenack) Eisenack, 1938_........... Hystrichosphaeridium ohioensis $\mathrm{n} . \mathrm{sp}_{\text {....... }}$

Genus Micrhystridium Deflandre, 1937........ Micrhystridium sp. A._._.

Disseminules of unknown relationship ............

Genus Tasmanites (Newton) Schopf, Wilson, and Bentall, 1944.

Tasmanites huronensis (Dawson) Schopf, Wilson, and Bentall, 1944, emend. Winslow.

Tasmanites sinuosus n. sp...............

Tasmanites sommeri $\mathrm{n} . \mathrm{sp}$

Tasmanites sp. A.

Tasmanites sp.......

Literature cited

85

\section{ILLUSTRATIONS}

[Plates 1-22 follow index; plates 23-27 in pocket]
Plate 1. Chagrin, Ohio, and Bedford shales.

2. Hand specimens of Berea sandstone and Bedford shale.

3. Triletes auritulus n. sp.

4. Triletes auritulus $\mathrm{n}$. sp. and T. cervicornis $\mathrm{n}$. $\mathrm{sp}$.

5. Triletes cervicornis n. sp., T. spp., and T. catenulatus n. sp.

6. Triletes catenulatus $\mathrm{n} . \mathrm{sp}$.

7. Triletes? sp. B, T. catenulatus n. sp., T. variabilis $\mathrm{n}$. sp., T. aries $\mathrm{n} . \mathrm{sp}$., and T. triquetrus $\mathrm{n}$. sp.

8. Triletes globulus $\mathrm{n}$. sp.

9. Triletes globulus n. sp. and T. aries n. sp.
Plate 10. Dicrospora sp., D. bedfordi n. sp., and D. amherstensis n. sp.

11. Dicrospora sp., D. sp. A, and D. porcata n. sp.

12. Dicrospora n. gen.

13. Dicrospora multifurcata $\mathrm{n}$. sp.

14. Reticulatispōrites.

15. Laevigatosporites and Canthospora $\mathrm{n}$. gen.

16. Endosporites, Grandispora, and Radforthia n. gen.

17. Calamospora, Triletes, Punctatisporites, Densosporites?, Convolutispora, and Verrucosisporites?

18. Cirratriradites, Lycospora?, Endosporites?, Verrucosisporites, Anapiculatisporites?, and Punctatisporites? 
Plate 19. Hystrichosphaeridium, Canthospora?, Endosporites?, Verrucosisporites, Triletes, and Callixylon.

20. Tasmanites.

21. Tasmanites, Spermatites, and Sclerenchymatous "nests."

22. Hystrichosphaeridium, Micrhystridium, Granulatisporites, Anapiculatisporites?, Densosporites, Punctatisporites, Dicrospora, Radforthia, Cyrtospora, and Reticulatisporites.

23. Diagrammatic compilation showing stratigraphic occurrence and relative abundance of microfossils from Upper Devonian and Lower Mississippian rocks at 10 localities in Ohio.

24. Stratigraphic occurrence and relative abundance of microfossils from the Barberton core at locality 6 .

25. Stratigraphic occurrence and relative abundance of microfossils in cuttings from the Newcastle well at locality 7 .

26. Stratigraphic occurrence and relative abundance of microfossils in cuttings from the Logan well at locality 8.

27. Generalized correlation chart showing DevonianMississippian stratigraphic sequence of Ohio and other areas in which plant microfossils have been studied.

Frgure 1. Stratigraphic occurrence and relative abundance of microfossils from the Chillicothe core at locality 10.

2. Index map of Ohio showing general location of collecting localities
FIgURe 3. Diagrammatic columnar sections at four localities in Ohio, showing the stratigraphic position of foerstian remains...............

4. Diagrammatic columnar sections from seven localities showing the stratigraphic occurrence and relative abundance of spores of Endosporites lacunosus n. sp. and E. cha-

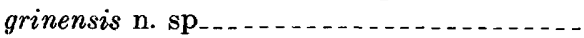

5. Histogram showing the size variation of megaspores of Triletes globulus $\mathrm{n}$. sp.........

6. A, Diagrammatic proximal view of a spore of Endosporites? pseudoradiatus n. sp. B, Diagrammatic axial section of same spore....

7. $A$, Diagrammatic proximal view of a spore of Endosporites? crassaspinosus n. sp. B, Diagrammatic axial section of same spore....

8. $A$, Diagrammatic proximal view of a spore of Canthospora patula n. sp. B, Diagrammatic axial section of same spore.............

9. $A$, Diagrammatic proximal view of a spore of Canthospora cracens $\mathrm{n}$. sp. B, Diagrammatic axial section of same spore

10. Diagram of diameter and wall dimensions of Tasmanites disseminules...............

11. Reproduction of original illustration (Dawson 1886, fig. 4) of lectotype specimen of Tasmanites huronensis (Dawson) S. W. \& B. emend. Winslow ......................

12. Tasmanites sommeri $\mathrm{n}$. sp. Line tracing from photograph showing the concentric wall layering ............................
Page 



\title{
PLANT SPORES AND OTHER MICROFOSSILS FROM UPPER DEVONIAN AND LOWER MISSISSIPPIAN ROGKS OF OHIO
}

\author{
By Marcia R. Winslow
}

\begin{abstract}
Upper Devonian and Lower Mississippian rocks of Ohio contain plant spores which are the microscopic disseminules of cryptogamic plants (or their equivalents among plants of more advanced organization), woody fragments, and foerstian remains. Microfossils of unknown affinity, such as the cysts of hystrichosphaerids and disseminules of Tasmanites, are also present and in places abundant. The main purpose of this report is to provide a systematic description and to record stratigraphic occurrences of the different types of spores and sporelike microfossils.

Maceration residues prepared from outcrop, well cutting, and core samples, at 10 localities in Ohio east of the Cincinnati arch, represent about 130 stratigraphic horizons; nearly all the residues contain recognizable microfossils. The stratigraphic section, which spans the controversial Devonian-Mississippian contact, contains the Olentangy shale, Ohio shale (Huron and Cleveland members where differentiated), and Chagrin shale of Late Devonian age and the Bedford shale, Berea sandstone, Sunbury shale, Cuyahoga formation, Black Hand formation, and Logan formation of Early Mississippian age. Additional samples from Middle Devonian límestones and from Pleistocene beds in which Upper Devonian and Lower Mississippian microfossils had been redeposited yielded microfossils useful for comparative purposes.

The land-plant microfossils of Upper Devonian and Lower Mississippian rocks of Ohio, only briefly mentioned in previous literature, include a multitude of types having great botanical disparity and represent varied plant associations. Within the section studied, diversified assemblages of land-plant spores first appear in the Upper Devonian Chagrin shale (or its equivalent) and persist, with changes in composition and relative abundance of different types, throughout the younger strata. Many of the smaller types of land-plant spores are widely dis. tributed, but megaspores are more restricted in lateral distribution, apparently in areas near shoreline and closer to their place of origin. Microfossil assemblages in the basal part of the Bedford shale of Early Mississippian age in northern Ohio appear very distinct from those of older beds because of the abundance and variety of megaspores. The greater frequency of megaspores is probably due to increased stream velocity and proximity of shoreline during deposition of the Bedford shale, rather than to a sudden proliferation of land plants. Nevertheless, some of the small spores of the Bedford shale also differ greatly from those occurring in underlying beds. A gradual invasion of the borderlands of the Ohio embayment by communities of rapidly evolving plants may account, in part, for the changed aspect of the assemblages early in Mississippian time. Spores of the overlying Berea sandstone are very
\end{abstract}

similar to those of the Bedford shale. More distinctive assemblages seem to characterize the Cuyahoga, Black Hand, and Logan formations.

Hystrichosphaerids, previously unrecorded in Upper Devonian and lowermost Mississippian rocks of Ohio, occur in the Olentangy shale, but are found most abundantly in the Chagrin shale or in the upper part of the Ohio shale. Within the area studied, they are not known to occur in rocks younger than the Berea sandstone. The forms referred to Hystrichosphaeridium and Micrhystridium are probably representative of planktonic marine or brackish-water organisms.

Tasmanites disseminules, globular to disk-shaped propagative bodies of enigmatic affinity and function, are abundant and widely distributed in the otherwise poorly fossiliferous ohio shale. These microfossils have been noted many times previously as "macrospores" or "sporangites." Four species are distinguished, three of which appear to be restricted stratigraphically. However, the lack of many distinctive morphologic features may limit the value of these disseminules for stratigraphic purposes. Tasmanites apparently is indicative of a marine or brackish-water environment.

Foerstian remains, represented by small black ovate or elongate, sometimes bifurcating, thalli that may be allied with the brown algae, are restricted to a zone 60-150 feet thick within the lower part of the Ohio shale. The foerstian zone is persistent through the area covered in this study and evidently extends over a wide area in the Eastern United States. The stratigraphic occurrence suggests that these plant fossils may represent members of a pelagic or sargassoid plant community.

Many of the spore types described in this report are similar to those reported in the few published studies on rocks of comparable age from other parts of the world. In spite of general similarities. very few appear conspecific with forms previously described. Some species from the Logan formation seem very closely related to those described from the Upper Mississippian rocks in Illinois and Kentucky. Although 2 species of $\mathrm{Hy}$ strichosphaeridium and 1 species of Tasmanites reported here have been previously described, the other forms from the Upper Deronian and Lower Mississippian rocks of Ohio seem relatively distinct.

Genera identified on the basis of plant and other microfossils in the Upyer Devonian and Lower Mississippian rocks of Ohio include: Triletes, Lycospora?, Cirratriradites, Endosporites, Densosporites, Dicrospora, Calamospora, Reticulatisporites, Punctatisporites, Granulatisporites, Verrucosisporites, Laevigatosporites, Grandispora, Cyrtospora, Canthospora, Convolutispora, Radforthia, Anapiculatisporites?, Callixylon, Spermatites, Hystrichosphaeridium, Micrhystridium, Tasmanites, and 
Foerstia. Of these genera, Dicrospora, Cyrtospora, Canthospora, and Radforthia are named as new. More than 80 species and unnamed forms are referred to the various genera; 31 new species are described.

\section{INTRODUCTION}

\section{MICROFOSSIL ASSEMBLAGES AND THEIR GEOLOGICAL AND BOTANICAL SIGNIFICANCE}

The main emphasis of this paper is on land plant spores, the microscopic disseminules of cryptogamic plants or their equivalents among plants of more advanced organization, found in maceration residues of rocks from Ohio, principally rocks of Late Devonian and Early Mississippian age. Some other resistant plant parts are also described. Secondary emphasis is placed on the study of Tasmanites, distinctive globular to disk-shaped centrically symmetrical propagative bodies of enigmatic alliance which occur most abundantly in this country in Devonian and Mississippian black shales. Their occurrence has generally been recorded in the literature as "sporangites" or "macrospores." The study of the hystrichosphaerids, probably representative of several different kinds of unicellular planktonic marine to brackish-water organisms, is not extensive. They are described mainly to emphasize their presence in the Ohio shale, an occurrence not noted in previous literature. The somewhat restricted stratigraphic occurrence of the foerstians, but not their morphological characteristics, is also presented. The foerstians are represented by black ovate or elongate, sometimes bifurcating, sporogenous thalli; they may be allied with the Phaeophyceae or brown algae and are possibly planktonic marine or brackish-water plants. All the above microfossils were isolated from their host rock by use of disaggregation and maceration techniques employing hydrofluoric acid and (or) Schulze's solution followed by humic dispersal in potassium hydroxide.

Plant microfossils may include spores and pollen, fragments of waxy, oily, or otherwise resistant plant parts such as cuticles, seed coats, sporangia, and fragments of fusinized vascular tissue. Microscopic remains of larger plants, for example, identifiable splinters of woody tissue and foerstian remains are also considered part of the plant microfossil assemblage. Microfossils of unknown or uncertain affinity, such as Tasmanites and hystrichosphaerids, sometimes occur with the transported spores of land plants. All these microfossils, as well as chitinozoans and scolecodonts, are resistant to physical and chemical degradation. Other types of microfossils, for example Foraminifera, radiolarians, holothurian sclerites, conodonts, sponge spicules, ostracodes, and fish fragments, may occur with the chemically resistant microfossils, but generally do not withstand the hydrofluoric and nitric acids used in maceration treatment and are therefore not present in the maceration residues.

Any of the above microfossils may be present, dispersed as minute fragments, in sedimentary rocks. The types of microfossils and the species represented depend on the age of the rocks, the sedimentary environment, distance from shoreline, prevailing water current or wind direction, and conditions for preservation that exist in the environments traversed since the time of dispersal.

Most micropaleontologic studies of maceration residues are concerned with problems of stratigraphic correlation or ecological interpretation. Of the plant material available in maceration residues, isolated spores and pollen have been the most thoroughly studied. Spores and pollen are generally produced in great numbers, are usually resistant to physical and chemical attack, and differ sufficiently so that many taxonomic groups can be recognized.

Spores and pollen have the greatest chance for abundant representation near their site of production, as in coal beds, for example, but their distribution is only incidentally controlled through bioselective agencies. Because spores and pollen are characteristically adapted for dispersal, they may be widely scattered in near-shore marine detrital deposits. Thus, they will occur in sedimentary association with marine nektonic and planktonic organisms. Spores and pollen may also be present in near-shore deposits from which marine types of fossils are excluded or in marine beds in which calcareous fossils are poorly preserved or have been destroyed by scavengers. Therefore, spore and pollen distribution is not as restricted as that of benthonic invertebrates. Thus, the results of plant microfossil studies serve to supplement other types of paleontologic information and extend the range of fossil interpretation for purposes of stratigraphic research. Kuyl, Muller, and Waterbolk (1955, figs. 6, 8) give two diagrammatic sections showing the divergence between palynological correlation, thought to represent timestratigraphic correlation, and correlation based on lithology and benthonic foraminiferal assemblages.

Disparity between the actual plant frequency in an ancient flora and the record of the flora as shown by preserved microfossils is to be expected. Spores and pollen are not all similar in their resistance to chemical attack nor equally adapted for dispersal. Nevertheless, although no fossil records are perfect, it is normal to find a far greater representation of plant kinds among the microfossils than is known from megascopic remains. This is particularly true of the Lower Mississippian flora in this country where the leaf and stem fossil representation is rather scant. 
The plant microfossil assemblage being deposited at any given time is a record, although incomplete, of the terrestrial and aquatic flora then existing. Any sudden change in a plant community or gradual changes over a long period of time will be shown by the changed aspect of the microfossil assemblage in the surrounding or bordering sediments. Once this pattern of change is established for a sedimentary basin, stratigraphic correlations may be made with greater accuracy. Kuyl, Muller, and Waterbolk (1955, p. 49) point out that although evolution forms the backbone of palynological zonation, climatic and edaphic conditions may cause additional variations in the flora that may be of more importance for local correlation work. Kosanke (1955) and Norem (1955) emphasize the importance of understanding the ecological relationships of the parent plants and the causal factors of plant distribution in time and space.

Oil company paleontologists (Armstrong, 1953; Hoffmeister, Staplin, and Malloy, 1955a, 1955b; Kuyl, Muller, and Waterbolk, 1955; Norem, 1955; Wilson and Hoffmeister, 1955; Woods, 1955) are taking practical advantage of the relative abundance of spores and pollen to hystrichosphaerids and other fossils in well samples. Armstrong (1953) reports that fossil spores and pollen occur in about 45 percent of well cuttings examined, whereas Foraminifera and larger fossils are normally present in less than 1 percent. Pollen and spores are most abundant near ancient shorelines, the smallest or lightest forms being carried seaward the farthest. Microforaminifera and hystrichosphaerids occur with the spores and pollen, but, in contrast, occur more abundantly as the distance from shoreline increases. Technologists (Armstrong, 1953), on the basis of information derived from spore assemblages from only three sets of well cuttings, say they are able to reconstruct the position of an ancient shoreline.

The possibility of contamination of microfossil assemblages in clastic sediments by secondarily deposited microfossils must always be considered. Hough (1934), Dijkstra (1950), and Kuyl, Muller, and Waterbolk (1955, p. 55) have noted occurrences of microfossils that have been eroded from older beds and redeposited in younger beds. The recognition of such occurrences is important in that it may correct a false age attribution or shed light on possible sediment source areas.

A study of microfossils found in maceration residues not only aids in the correlation of rock units, but may also yield information, when compiled from many sources, on the phyletic and ecologic patterns of the past.

\section{NATURE OF PRESENT PROBLEM}

The Upper Devonian and Lower Mississippian rocks of Ohio have long been noted for their general paucity, with the exception of the conodonts, of well-preserved stratigraphically significant fossils. The Upper Devonian Ohio shale, in particular, has posed both problems of subdivision and environmental interpretation. The stratigraphic position of the Devonian-Mississippian boundary has been the subject of continued controversy. Although plant microfossils, Tasmanites disseminules (which have been referred to commonly as "plant spores" or "sporangites"), foerstian remains, and isolated large plant remains are known to occur in this sequence of rocks, very little paleontologic emphasis has been placed upon them.

The rather extensive research done on plant and other microfossils contained in maceration residues of all types of rocks has proved of great value in the correlation of rock units, in ecological or environmental interpretation, and in the elucidation of the distribution, both areal and with time, of faunas and floras. However, there has been little extensive previously published work on plant microfossils of Late Devonian and Early Mississippian age. Therefore, this investigation was intended to yield results that might lead to a more precise knowledge of the types of microfossils contained in these beds and their environmental and stratigraphic significance. The first step towards this knowledge is the systematic, detailed investigation and description of the forms encountered and the recording of their areal and stratigraphic distribution.

One of two primary objectives of this report is the presentation of the generalized stratigraphic distribution chart (pl. 23) of the microfossils studied, as well as the more detailed distribution charts (pls. 24-26 and fig. 1) based on well core and cuttings samples. Plate 23 represents a collation of all recorded occurrences from all localities and presents a necessarily generalized picture of the relationships of microfossil occurrences, one type to another and through the sequence of Upper Devonian and Lower Mississippian rocks. Therefore, relative thicknesses of formations, rather than thickness at a given locality, are represented on this chart. The distribution and relative abundance of Tasmanites, Dicrospora, foerstian remains, and Triletes, given in the first four columns, are based upon all observations of the total core or well cuttings sets involved; that of the individual species are based mainly on maceration residues.

Because stratigraphic relations of the Huron and Cleveland members of the Ohio shale to the undiffer- 


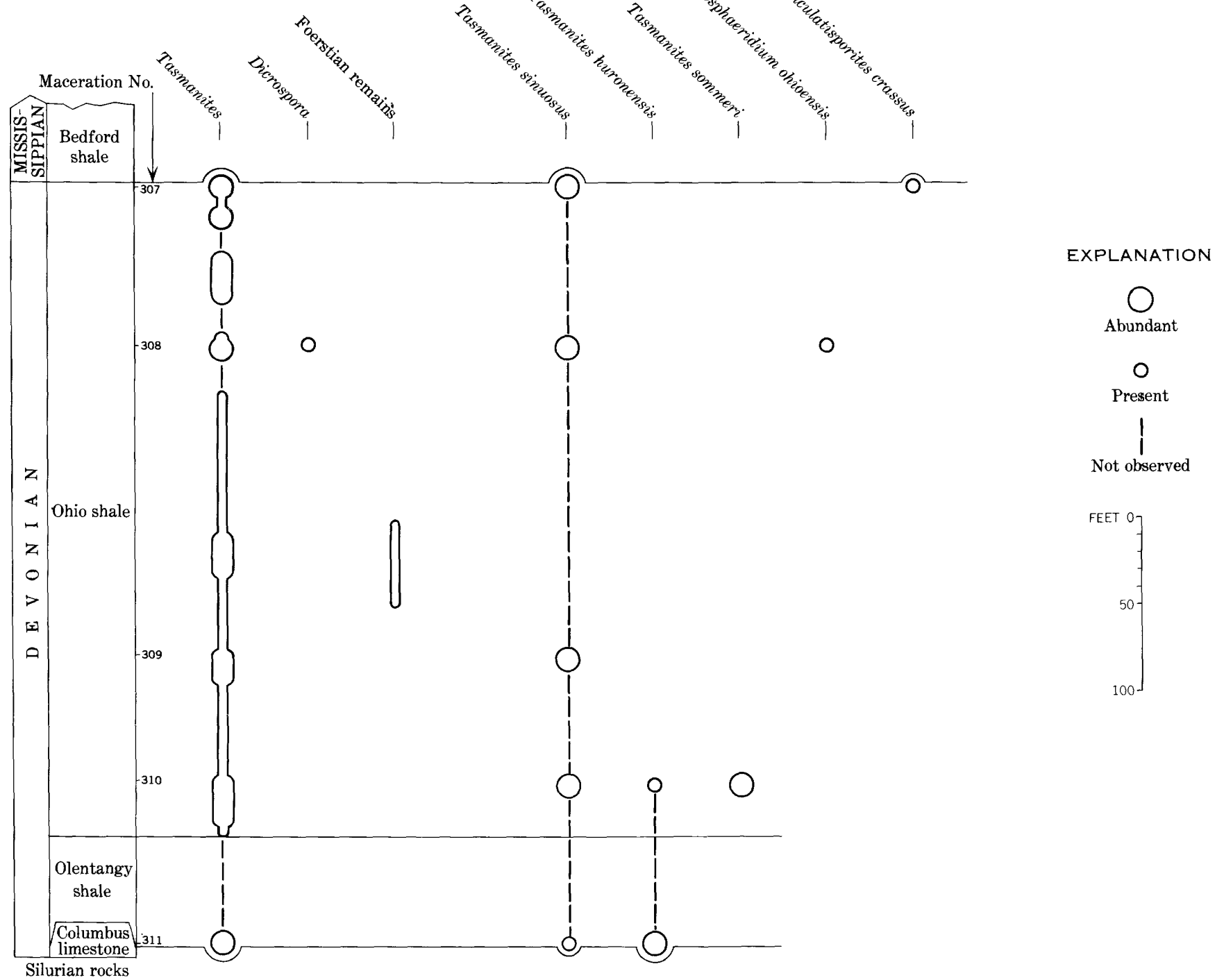

Figure 1.-Stratigraphic occurrence and relative abundance of microfossils from the Chillicothe core at locality 10 (fig. 2). Genera and species are listed in the same order as on plate 23 .

entiated Ohio shale of southern Ohio and to the Chagrin shale of eastern Ohio are partly still in question and because the lithologic boundaries probably transgress "time lines" from locality to locality, the microfossil occurrences at core and well-cutting localities are presented in detail on plates $24-26$ and on figure 1. The genera and species on plates $24-26$ and figure 1 are, however, listed in the same order as on plate 23 where the taxa are arranged in the stratigraphic order of their appearance.

The other primary objective is the detailed description of the microfossils studied so that the report may be of maximum comparative value in future work. It is generally held that the study of plant microfossils less than $200 \mu$ (microns) in diameter is the most pro- ductive of results needed for stratigraphic correlation. However, larger microfossils may be equally valuable and should not be disregarded. The presence of algal(?) foerstians $(2-5 \mathrm{~mm})$ and Tasmanites $(25 \mu$ to more than $800 \mu$ ) in the Upper Devonian dark shales may aid in subdividing this thick sequence of beds. Fragments of megaspores are commonly found in small spore assemblages and, unless some study has been given to these larger spores, the ornamentation fragments found with the smaller fossils in fine-sized residues may mean little to the investigator. For these reasons, and because no similar studies on Uppon Devonian and Lower Mississippian rocks of Ohio or of any other state have ever been published, attention is given to the total maceration residue assemblage including small 
and large spores, vegetative fragments, remains of foerstians, hystrichosphaerids, and Tasmanites. Occurrences of fish plates, scolecodonts, conodonts, ostracodes, brachiopods, and other fossils were noted during the examination of outcrop, core, and cuttings samples prior to maceration.

The plant microfossils in the Ohio Upper Devonian and Lower Mississippian rocks include a multitude of types having great botanical disparity. The main emphasis is placed on those microfossils occurring in beds immediately above and below the Devonian-Mississippian boundary, beds generally correlative with those from which Cross and Hoskins (1952) describe the Devonian-Mississippian transition flora. Numerous spores, present in the Chagrin shale, Cuyahoga formations, Black Hand formation, and Logan formation, remain undescribed. Only the more morphologically distinctive or more abundantly occurring types from these units are described in the present report. More detailed work on the microfossils of the Chagrin shale and older beds will be necessary before adequate comparisons can be made with the plant spore types described by Naumova (1953) from the Upper Devonian of the Russian platform.

The present investigation is mainly concerned with samples from the Upper Devonian Olentangy shale, Ohio shale (Huron and Cleveland members where differentiated), and Chagrin shale, and from the Lower Mississippian Bedford shale, Berea sandstone, Sunbury shale, Cuyahoga and Black Hand formations (undifferentiated), and Logan formation from 10 localities in Ohio east of the Cincinnati arch (fig. 2). Additional samples of Devonian black shale from other States and samples of Middle Devonian Columbus limestone were studied for comparative purposes. Reworked Upper Devonian microfossils, found in the Pleistocene glacial deposits in the Great Lakes region, were also studied with regard to their relative resistance to erosion and secondary deposition. The strata investigated contain the contrasting spore assemblages mentioned by Dawson (1888; also p. 6 of this report), as well as the controversial Devonian-Mississippian boundary. In view of the recent study by Pepper, de Witt, and Demarest (1954) on the Bedford shale and Berea sandstone and studies by many others on the geology of Ohio, as noted in the present writer's section on "Stratigraphic relations and sample localities," there is no occasion for detailed discussion of the stratigraphic relations.

The present investigation was begun in 1952 as part of a program of graduate study at The Ohio State University. Part of the material derived from this study was submitted in the spring of 1954 as a master's thesis. The study was continued and mainly completed prior to
September 1955. Literature citations include very little published after that date.

\section{ACKNOWLEDGMENTS}

The writer is grateful for the interest and advice of many associates, members of the staff at the Geological Survey laboratory, at Columbus, Ohio, The Ohio State University Department of Geology, and the Ohio Division of Geological Survey. Dr. J. E. Carman, of The Ohio State University, provided some of his manuscript material regarding the Chillicothe test core. Sets of well cuttings and cores were made available for this study by the Ohio Division of Geological Survey, and an important study collection (loc. 4) was supplied by Dr. C. S. Bacon, Jr., of Case Institute of Technology. J. D. Winslow, U.S. Geological Survey, assisted the author in the field and in some of the photographic work. J. F. Pepper, Wallace de Witt, Jr., and W. H. Hass, of the U.S. Geological Survey, aided in the interpretation of stratigraphic data and Mr. Hass generously provided the author with his manuscript log of the Barberton test core. The work was done under the supervision of J. M. Schopf.

\section{REVIEW OF PREVIOUS STUDIES \\ POLLEN AND SPORES GENERAL HISTORY}

Spores were certainly recognized as plant associates long before the foundation of modern botany and the recognition of their true function in the life cycle of plants. Wilhelm Hofmeister (1851) gave botanists an appreciation of heterospory and the function of spores in the life cycle of plants in the 1860 's, nearly a hundred years ago. The general picture was not completed until the work of Strasburger ${ }^{1}$ and others 30 years later which established the relation of reduction division and fertilization in the life cycle of plants.

Bennie and Kidston (1886) credit Morris (1840) as being the first to illustrate isolated fossil megaspores. Bennie and Kidston (1886) published an excellent paper on the occurrence of spores in the Carboniferous of Scotland but did not fully realize the application which such a study might have. Reinsch in 1884 published a monographic work on plant remains from the Moscow coal basin and other localities. Although his drawings are meticulously done, he had no appreciation of the function of spores and, therefore, a satisfactory interpretation of their structure was not possible. Geological interest in plant microfossils has been stimulated by Quaternary pollen studies on peat, starting with Lagerheim, Von Post, and Erdtman in the early part of the 20 th century. ${ }^{1}$

${ }^{1}$ See Wodehouse $(1985$, p. 15-100) for a comprehensive historical review and discussion of the early investigators. 
Most of the investigations of pre-Quaternary spores, if not purely paleobotanical, were undertaken principally for aid in the correlation of coal beds, such as was Raistrick's (1934) work on the microspores of the British coal measures and Zerndt's $(1934,1937)$ work on the megaspores in the coals of the Polish coal basin. It had been realized in the early 1930 's that sediments other than coals also may contain spores and pollen. Wilson (1946) emphasizes the possibility of correlating sedimentary rocks by plant microfossil investigations.

In the last 15 years stratigraphic studies based on fossil spore and pollen (and on hystrichosphaerid) occurrences in sedimentary deposits have been emphasized more and more. Much of this work is being undertaken in petroleum company laboratories (Armstrong, 1953; Hoffmeister, Staplin, and Malloy, 1955a; Kuyl, Muller, and Waterbolk, 1955) ; active investigation of coals has continued (Dijkstra, 1946; Cross, 1947; Kosanke, 1950; Arnold, 1950). I Literature on the more general aspects, as well as detailed studies of the various facets of spore and pollen studies, is becoming voluminous. Erdtman (1955) gives bibliographic references to some of the older as well as newer literature on palynology.

As for the paleobotanical studies of pollen and spores, more emphasis is being placed on the natural association of types of spores and pollen in fructifications, as can be seen, for example, in the work of Chaloner (1951; 1953a, b, c; 1954a) and Felix (1954).

\section{PREVIOUS WORK IN OHIO}

In 1888 Sir William Dawson in "The Geological History of Plants" remarks about the great variety of spores and "sporangia" in the Carboniferous, as shown, for example, in the Bedford shale. In a specimen of this shale which Dr. Orton sent to him, he notes (p. 56-57) the presence of Triletes and spinous and hooked spores or "sporangia" which he compares with the still problematic genera Sporocarpon, Zygosporites, and Traquairia, forms discussed and illustrated by Williamson in 1880. Dawson contrasted the great variety of plant microfossils in the Bedford shale with the almost exclusive predominance of the abundant and widely disseminated Tasmanites sporelike microfossils in the shales underlying the Bedford shale.

Bartoo (1948, 1950) notes the presence of lycopod stems and cones and a Calamites stem in a Sunbury (?) shale collection from the Berea Quarry at Berea, Ohio. She mentions the presence of trilete spores in the cone compressions. Bowen ${ }^{2}$ briefly notes and illustrates a spinose lageniculate spore from the Sharpsville sand-

Bowen, A. S., 1951, The stratigraphy and micropaleontology of the Mississippian strata above the Berea formation in northern Geauga and southern Lake Counties, Ohio: Unpublished master's thesis, The Ohio State University, 1951. stone and lycopod spores from the Orangeville shale of the Cuyahoga group of northeastern Ohio. Although many reports have mentioned "macrospores" or "sporangites" since 1888, virtually nothing has been added to the knowledge of these forms.

\section{PERTINENT PLANT-SPORE LITERATURE}

Literature dealing with pre-Devonian occurrences will not be discussed here, but reviews of the existing literature may be found in papers by Høeg (1942, p. 147) and Hoffmeister, Staplin, and Malloy (1955a, pp. 9,10). With the exception of Naumova's paper (1953), very little work has been done on Devonian spores, in comparison with that done on Pennsylvanian spores. Potonié and Kremp $(1954$, p. 185) note the lack of spore investigations of Upper Devonian beds. Most of the literature on Mississippian spores is not concerned with spores of earliest Mississippian age. Hoffmeister, Staplin, and Malloy (1955a) note the lack of information about spores of this age.

Plate 27 shows the stratigraphic sequence in Ohio as well as that in several other localities where plant microfossils of either Devonian or Mississippian age have been studied. The approximate stratigraphic intervals are marked to emphasize the comparative age of many previously studied assemblages. The correlations are generalized but are based on previously published paleontologic evidence and the correlation charts given by Cooper and others (1942) and Weller and others (1948).

Devonian.-Potonié and Kremp (1954, p. 185) note those authors who have contributed to the study of Lower, Middle, and Upper Devonian spores. Lang (1925) describes several spore types from the Cromarty fish beds of Middle Old Red Sandstone age in Scotland. Some of his types are comparable to some specimens found in the Upper Deronian rocks of Ohio. Kräusel and Weyland (1929) describe several bifurcatespined spores from the Middle Devonian of Elberfeld, Germany. Nikitin (1934) describes the genus Kryshtofovichia, comparable in several respects with Dicrospora described in this paper, from the Devonian of the Kursk and Voronezh region in central Russia. Arnold (1936) illustrates spores, apparently identical with Lang's type G spores (cf. Dicrospora), from the Devonian of Quebec. He notes their occurrence in the Pocono (?) formation (Arnold, 1933) and in the Devonian of the Appalachian region (Arnold, 1937). Thomson (1940) describes 17 types from the Middle Devonian rocks of Estonia. He later (1952) incorporates this material with some additional material into a short general paper on spore forms of Early and Middle Devonian age. Not one of the spores described from Ohio appears to be conspecific with any 
that Thomson illustrates. Høeg (1942, p. 146-147) describes isolated spores, probably of latest Middle Devonian age, found in Mimer Valley, central Spitzbergen. He classifies these spores according to the system set forth by Thomson (1940). Eisenack (1944) also describes spores, probably of Late Devonian age (Isborsker Stufe), comparable to several illustrated by both Lang and Thomson. Hsü has evidently done considerable work on the spore assemblages of Devonian beds in China (Sahni, 1948, p. 244, 245; Sitholey, 1950, p. 12). Unfortunately only these abstracts were available to the author. Radforth and McGregor (195t) have recently investigated the composition of spore assemblages from rocks of Silurian and Devonian age from several localities in Canada (pl.27). At least one of the spore types they describe from Middle Devonian beds near Hudson Bay apparently ranges through Upper Devonian and Lower Mississippian rocks of Ohio. Hoffmeister, Staplin, and Malloy (1955a) discuss briefly and illustrate a varied spore assemblage from the Upper Devonian of Alberta.

The only comprehensive report on Upper Devonian small spores is that of Naumova (1953), who studied Upper Devonian (and Middle Devonian) spores and "pollen" of the Russian platform (pl. 27). Rather general comparisons, noted in the section on "Systematic descriptions," can be made with some microfossils of Late Devonian age in Ohio. Nothing comparable to her Archaeoperisaccus spores was found. Because most of the material described in the present paper is of earliest Mississippian age, only a few forms similar to Naumova's would be expected.

Mississippian.-In $188+$ Reinsch published his monumental work on plant microfossils, many of which were derived from Lower Carboniferous beds of the Moscow coal basin. Some of the spores described from Ohio seem comparable to some of those Reinsch illustrated. Several of the lageniculate megaspores described in this paper (pl. 27) can be compared with those illustrated by Bennie and Kidston in 1886.

The most important comparative material for megaspore studies is on spores of Carboniferous age investigated by Nowak and Zerndt. (1936) and by Zerndt $(1934,1937)$ from the eastern part of the Polish coal basin (pl. 27). Schopf, Wilson, and Bentall (1944) and Dijkstra (1946) have brought the views expressed in these three papers and others up to date and revised them according to recent views on plant spore relationships.

Naumova (1938) describes small spores of Early Carboniferous age from the Moscow coal basin. Luber and Waltz (1938) also describe occurrences of small spores of Tournaisian and Visean age in coals at this locality and others in Russia (pl, 27). In addition Raistrick
(1938) and Knox (1948) describe some small spores in Lower Carboniferous coals and coals of the Limestone Coal Group (pl. 27).

Berry (1937) describes small spores from a coal of Mississippian (?) age in Tennessee (pl. 27). Schemel (1950) describes small spores and some megaspores from a coal of Springer or Chester age in Utah (pl. 27). Hoffmeister, Staplin, and Malloy (1955b) give a detailed account of the assemblages of small spores in the Hardinsburg sandstone and a summary account of that in the Waltersburg sandstone (pl. 27), both of Late Mississippian age from Kentucky and Illinois. A recently published account of megaspores of Mississippian age from this country is Chaloner's (1954b) study of samples from localities in Michigan, Indiana, and Pennsylvania (pl. 27). The oldest megaspores he studied are probably equivalent in age to the youngest ones described here from the Logan formation. Comparisons of Chaloner's material and conclusions with the results of this study are given later.

\section{FOERSTIANS AND LARGER PLANT FOSSILS}

A laterally persistent zone of foerstian remains, small $(2-5 \mathrm{~mm})$ ovate or elongate, sometimes bilobed, plant remains of algal(?) origin, has already been noted in the Ohio shale or its equivalent by Cross and Hoskins (1951), Arnold (1954), Hass (1956), and by J. M. Schopf (oral communication, 1955). Cross and Hoskins $(1951$, p. 722 ) note that the fossils are confined to a zone between $1 / 7$ and $1 / 5$ of the way up in the black shales, regardless of the total thickness of the sequence. They report the occurrence of this zone from numerous outcrop localities in Ohio, Kentucky, and Tennessee. Hass $(1956$, p. 21) notes the association of foerstians only with conodonts like those occurring in the lower fauna of the Gassaway member of the Chattanooga shale. He notes foerstian occurrences in southwestern Virginia, in northeastern Oklahoma, and in areas already mentioned by Cross and Hoskins. No attempt is made in the present paper to describe these plants nor to discuss the problems of affinity and nomenclature. Generally two genera, Foerstia and Protosalvinia, have been recognized in the Foerstiales. Foerstian affinities, regarded as more or less problematic, and morphology are treated more fully by White and Stadnichenko (1923), Kidston and Lang (1924), Kräusel (1941), Schopf, Wilson, and Bentall (1944), Lang (1945), Arnold (1954), and reviewed by Schopf (1957).

Read and Campbell (1939), Amold (1937, 1939, 1948a), Cross and Hoskins (1951, 1952), Hoskins and Cross (1951, 1952), and Read (1955) have published results of investigations concerned with plant mega- 
fossils of Late Devonian and (or) Early Mississippian age in the Eastern United States. The information in these papers may be considered as a tentative guide to the possible affinity of some of the plant microfossils described by the present writer.

\section{HYSTRICHOSPHAERIDS}

According to Glaessner (1945, p. 20) and others, microfossils of this type are first described from Cretaceous flints as Tanthidium, a genus of modern freshwater algae, by C. G. Ehrenberg as early as 1836. Wetzel (1933) originally created the family Hystrichosphaeridae for microfossils from Cretaceous flints. In 1937, Deflandre, describing new genera and species of hystrichosphaerids from Cretaceous flints, examined the evidence on the nature and relationship of these microfossils. In 1938, Eisenack describes new genera and species of hystrichosphaerids and other microfossils from the Silurian rocks of the Baltic; he revises his previous classification to follow that started by Wetzel and revised by Deflandre. Deflandre (1945) also describes Silurian hystrichosphaerids, discusses much of the earlier literature, and compares his Silurian assemblage to that described by Eisenack. Deflandre (1952) reviews the hystrichosphaerids, indicates some of the more basic literature, and notes those papers that include extensive bibliographies. Erdtman (1945) observed living hystrichosphaeroid organisms and dinoflagellates in an investigation of the settling of pollen and spores in the sedimentogenous zone at the sea bottom off the southwestern coast of Sweden. He also notes recent compilations of literature on the subject of hystrichosphaeroid organisms. Eisenack (1954) describes very well preserved material from the upper Oligocene "Bhue earth" associated with the Baltic amber.

In this country, as early as 1862, M. C. White describes hystrichosphaerids and other microfossils from chert nodules of central and western New York. Laird (1935, p. 255-256) illustrates hystrichosphaerid-type microfossils from chert beds in the Lockport formation of Middle Silurian age near Ontario, Canada. Bashnagel (1942) describes similar Middle Devonian microfossils from the Onondaga limestone in central New York. He refers these fossils to living algae, basing his comparisons on the similarity of external characters. Fisher (1953) also reports and illustrates similar microfossils from the Middle Silurian Maplewood shale of Chadwick (1918) and Neahga shale of Sanford $(1933,1935)$ of New York. Whereas Bashnagel considers the Middle Devonian microfossils as of fresh-water origin, Fisher believes that those he describes might well be marine.

\section{TASMANITES}

Schopf, Wilson, and Bentall (1944) state that Dawson proposed the term "Sporangites" as early as 1863 , but point out that Dawson, in his original description and in some of his later papers, confused spores, sporangia, probable seeds, and probably unrelated thalloid plants in his conception of Sporangites. For this reason and others, they accept the generic designation, Tasmanites, given by Newton (1875) to the microfossils he described from the Tasmanite marine "coal" of Tasmania, and they regard Sporangites as a confused name.

Johnson and Thomas (1884) describe the occurrence of these microfossils (redeposited) in the glacial deposits and water supply in the Chicago area. In the same year Reinsch (1884) describes these microfossils, under his group Discieae, from the Ohio shale, from samples found in the Chicago area and from Tasmanite "coal" samples. Wethered (1886) describes some specimens from the Ohio shale as well as those found in the basal beds of the Lower Limestone Shales, Drybrook, Forest of Dean, to the east of the South of Wales coal field.

Except for Eisenack's (1931, 1938) work (Leiosphaera in part?) and Hough's (1934) paper on the occurrence of Tasmanites as secondary or tertiary deposition, little had been written on these enigmatic microfossils for 50 years, until the papers by Kräusel (1941) and Schopf, Wilson, and Bentall (1944). Sommer (1953) describes eight species of Tasmanites, found in dark shales from Barreirinha in Brazil that are presumed to correspond with the Hamilton group in age. Hoffmeister, Staplin, and Malloy (1955a) mention the occurrence of Tasmanites in rocks of Early Devonian to Early Mississippian age and state that the several species will perhaps become good index markers when they are better understood.

\section{PLANT SPORE MORPHOLOGY AND CLASSIFICATION}

Because the main emphasis of this paper is on fossil plant spores, their general morphology and classification is summarized below. The norphology and classification of other microfossils is given in the appropriate sections in the systematic descriptions.

\section{MORPHOLOGY, SYMMETRY, ORIENTATION, AND FORM}

In the botanical sense, a spore is the unicellular initial stage of the gametophytic or haploid (reduced chromosome number) generation. Each spore mother cell (diploid), produced in a sporangium, divides by meiosis and mitosis into four haploid unicellular bodies which are the spores. 
Mature spores are commonly enclosed in a resistant membrane or protective coat. The usual type of membrane substance is a waxy material allied with cutin and called sporonine by Erdtman (1943) and sporopollenine by Zetzsche (1932, p. 205). Dilute mineral acids generally do not affect it; concentrated acids attack it slowly. Alkalies react with sporopollenine only on melting. Acetyl bromide, which is capable of converting both cellulose and lignin into soluble substances, apparently has no effect on these spore membranes. The excellent preservation of spores in coal, peat, sandstone, and shale, and the commonly good, but often imperfect, preservation in black shales, indicates the effective resistance of sporopollenine against chemical, physical, and biological agencies operative in sedimentary deposits.

Spores are characteristically either radially (pl. 17, fig. 17 ; pl. 18, fig. 5) or bilaterally (pl. 15, figs. 1, 8) symmetrical. The type of symmetry is controlled by division of the spore mother cell and by orientation of the gametophyte that develops from them. If spore wall formation takes place following the two free nuclear divisions of the spore mother cell nucleus, the spores will be arranged tetrahedrally and each will possess fundamentally a radial symmetry. On the other hand, if the spore walls form after each of the two nuclear divisions, the spores will be arranged in either a tetragonal or a sectorial pattern, and each spore will show bilateral symmetry. Notable papers dealing with the developmental morphology of spores are by Siler (1934) and Selling (19tt).

Spores are described with reference to their relations in the original tetrad. The axis of a radially symmetrical spore passes through the center of the original tetrad. Contact faces are the two or three surfaces of mutual contact of spores within the tetrad. The lines between the contact faces usually are specialized dehiscence lines for the spores of vascular cryptogamic plants. In spores derived from tetrahedral.tetrads, the trilete suture forms along the three triradiate lines. In sectorial tetrads the monolete suture forms along the single central line. Tetragonal tetrads are principally known in angiospermous plants that have a different germinal adaptation. The distal surfaces of spores correspond to those exposed on the outside of the tetrad; the proximal surfaces correspond to the spore surfaces in mutual contact inside the tetrad. All parts of the spore coat beyond the margin of contact faces are regarded as distal. Bilaterally symmetrical spores possess 2 principal planes of reference; 1 taken proximodistally through the longest dimension and the second passing through the flat or proximal side to the center of the distal side. Diagrammatic illustrations of tetradic arrangement are given by Wodehouse (1935, p. 159, 160), Erdtman (1943, p. 52), Dijkstra (1946, p. 14), and others.

The original spore shape is often distorted by compression. It is important to note the compressional form, howerer, because this form is influenced by the original shape of the spore and, therefore, the preferred position of rest in a sedimentary deposit often leads to a manner of folding and orientation characteristic for spores of a particular species. Chaloner (1953a) gives an interesting account of how Triletes mamillarius-type spores, originally saucer shaped, react to compaction. Schopf (1941) had previously illustrated the same spore form in petrified material where the original spore shape was not distorted by compression. In some sedimentary deposits, open spores may be filled by mineral matter prior to compaction and preserved in virtually their original form. Many of the spores found in the coarse-grained Berea sandstone at locality 5 (pl. 4 , fig. 5 ) were filled with quartz grains and thereby maintained their original shape.

\section{HAPTOTYPIC AND EMPHYTIC CHARACTERS}

Wodehouse (1935) initiated the term "haptotypic" to refer to those features, often conspicuous on the proximal surface, that are mainly controlled or influenced by the contact relationships of each spore to the other three in the original tetrad. These features, the trilete rays (ray=one extension of the trilete suture or its expression as lips or folds), contact faces, arcuate ridges, and the flange (probably a hyperdeveloped structure equivalent to the arcuate ridge), are characters of tetrad configuration of radially symmetrical spores. The present writer has used the term "zonarium," in connection with spores of Dicrospora, to designate a type of arcuate ridge which may be highly developed and flangelike in proportions in spores of some species and from which the most proximal furcate-tipped spines radiate.

The emphytic characters are those which are inherited and bear no relationship to spore groupings in the tetrad but are more uniformly applied by the tapetal fluid or plasmodium after the spore tetrads separate inside the sporangium. Distal ornamentation such as spines or tubercles are deposited only under the influence of the tapetal fluid which surrounds and nourishes the spores. The type, shape, and size of these features are frequently relatively constant for spores of a given species.

The size of spores is highly variable as is shown by Schopf, Wilson, and Bentall (1944, pl. 3). Bocheński $(1939$, pl. 7, fig. 44$)$ has shown how great a variation in megaspore size may be found within a single cone of sigillariostrobus. Each species has its own characteristic mode of spore size variation and for this 
reason it is hazardous to regard absolute size as a specific criterion. Wilson (1934) and Reeve (1935) in studies of the modern genera Lycopodium and Selaginella show that each species is characterized by a larger or smaller normal range of variation. Irregularities of spore development can cause the size distribution curve to be asymmetric and variously skewed. The potentially functional spores generally are the most abundant class and usually prevalent among those recovered as fossils. For this reason the theoretical extremes of spore size within a species are never abundant in assemblages of isolated spores. Butterworth and Williams (1954) point out that the different maceration methods used to release spores from their sedimentary matrix affect the size of the spores differentially. The differential effect seems to be minor, however, when compared to the possible natural size variation.

\section{NOMENCLATURAL AND TAXONOMIC TREATMENT}

Terminology and detailed morphologic considerations are presented by recent authors so that plant microfossil descriptions can now be presented in adequate detail. Cross $(1950$, p. 52-63) gives an excellent review of the problems of morphology and classification. Schopf, Wilson, and Bentall (1944) discuss the classification of Paleozoic spores, large and small. Dijkstra (1946) presents a classification of megaspores. Potonié and Kremp (1954) describe a morphographic classification, a mixture of binomial nomenclature and an identification key, a classification accepted only in part by Hoffmeister, Staplin, and Malloy (1955 a and b). Naumova (1953) has recently expanded the Russian (see Naumova, 1939) classification to include new "genera." This classification, in general, seems to be a strictly morphographic one. Also pertinent are texts by Faegri and Iverson (1950), Erdtman (1943, 1947, $1952 \mathrm{a}, \mathrm{b})$, and Wodehouse (1935), all of whom present this material, principally on angiosperm pollen, in considerable detail. Kuyl, Muller, and Waterbolk (1955) and Traverse (1955) give excellent reviews and discussions of fossil pollen classification.

Most of the named and described Paleozoic genera have been discussed by Schopf, Wilson, and Bentall (1944), by Dijkstra (1946), and by Potonié and Kremp (1954). Potonié (1954) discusses the affinities of spores of these genera. Several new genera have been recently proposed by Hoffmeister, Staplin, and Malloy (1955b): These and numerous other papers were consulted as an aid to procedure and classification and for comparison of forms.

Many classification schemes have been proposed for spores, although most of these systems are based on rather arbitrary characters. Very few of these classifications are botanically significant because they do not attempt to express even broad natural relationships. Schopf (1938, p. 16) defined genera on the basis of larger taxonomic categories and in this sense the genera represent a natural classification. He pointed out that spore genera are artificial in that they correspond not to normal genera (usually based on features of the sporophyte), but to categories that often approximate the family or suborder in the standard taxonomic scheme. Schopf, Wilson, and Bentall (1944, p. 9) do not consider spores or any other morphological part of a plant in any stage of its life cycle to be a species. They regard a species of plant as a group of organisms (that is, a taxon) and point out that spores are probably just as definitive of species as any other fragmental part of the life cycle of a particular plant.

Some difficulty was expected and encountered in identifying older Paleozoic spores described here with those of published genera which are based mainly on material of Pennsylvanian, or equivalent, age. Many of the Upper Devonian and Lower Mississippian small spores seem to have affinities with previously described taxa. Other spores are so unusual that the author regards them as the basis of new taxa of generic rank. Most of the megaspores described here are allied with Triletes, a valid and correct name in spite of recent arguments (Potonié and Kremp, 1954) against its validity. Triletes antedates and displaces Laevigatisporites (Ibr.) Potonié and Kremp, 1954. The circumscription of the various other taxa of generic rank based on megaspores and applied by Potonié and Kremp is a taxonomic decision that each author must make.

The suprageneric classification of plants is patterned after that given by Tippo (1942).

\section{LABORATORY TECHNIQUES}

\section{SAMPLE EXAMINATION}

All samples collected in the field were first thoroughly washed and examined wet, immersed in water or xylol, with a Greenough-type microscope at magnifications of $\times 10$ to $\times 60$. The occurrence of organic material, carbonaceous and noncarbonaceous, and the lithology of the hand specimens were noted. Samples containing notable amounts of carbonaceous material or those representing critical horizons were set aside for maceration. Well cuttings (cable tool) were examined wet and studied in the same manner. Logs were prepared of the sets of cuttings on which lithology, occurrence of Tasmanites, foerstian remains, and other fossils, such as conodonts and brachiopods, were indicated. Core samples were split into halves, if necessary, and examined and logged in the same manner as the outcrop samples.

During laboratory examination and maceration, care 
was taken to keep the samples free from contamination. The possibility of contamination in the cable-tool cuttings was minimized by the selection, for maceration, of individual rock chips of cuttings considered characteristic of the depth interval. However, the possibility of syndepositional contamination by fossils eroded from older beds always exists.

As this microfossil study was not intended to be a quantitative one, no attempt was made to standardize sample size or weight. The samples varied in weight from 0.25 to 66 grams for outcrop samples which contained an obvious abundance of megaspores. Samples from cuttings and cores were smaller and usually weighed from 0.5 to 4 grams. A reserve of each sample macerated was usually saved.

\section{MACERATION PROCEDURES}

Most of the samples collected were noncoaly and, therefore, hydrofluoric acid was used to dissolve and disaggregate the mineral matrix in order to free the organic remains. Norem (1953, 1956) has recently presented preparation schedules similar in some respects to those used during this investigation.

Three variations in technique were used, all performed under a fume hood. Sandy or shaly samples with well-disseminated organic matter were macerated with dilute hydrofluoric acid. Samples of clastic rocks containing thick carbonaceous streaks, such as the Berea sandstone from locality 5 , were first treated with dilute hydrofluoric acid until the mineral matter was dissolved or disaggregated; the washed sample residues were then treated with Schulze's solution and then later with potassium hydroxide. Schopf (1938) and Kosanke (1950) discuss the Schulze method of maceration in considerable detail. Samples of thinly laminated or dense black shales were first soaked in ethylene diamine for 24 hours to a week in order to swell the samples and thus allow acids to attack the contained mineral matter more readily. These samples were then washed and treated in the same manner as clastic samples which contained thick carbonaceous streaks. The black shales of the Sunbury shale and the Cleveland member and the lower part of the Ohio shale contain a large amount of highly comminuted organic matter in addition to the microfossils. This remained in the residue and tended to obscure the plant microfossil assemblage. Some of the black shales were merely soaked in hydrofluoric acid until microfossils visible on the surface were separated from the matrix. No completely satisfactory technique was developed for macerating these black shales.

The above outline is generalized. Methods were varied, especially as to the length of maceration and concentration of the acids, depending on the lithology and response of the various samples.

\section{PREPARATION OF RESIDUES FOR MOUNTING}

After maceration each residue was washed thoroughly and either centrifuged or allowed to stand until settled. Residues were subsequently transferred to 95-percent alcohol. A few of the residues were then stained with a fow drops of a saturated solution of safranin in 95-percent alcohol. Residues were next transferred to 100 -percent alcohol and then to 100-percent xylol.

All residues were examined in a petri dish with a Greenough-type microscope by both reflected and transmitted light. Larger spores, greater than about $100 \mu$, were individually transferred from xylol to balsam mounts. Smaller spores were transferred en masse with a pipette, mixed with a drop of balsam on a slide, and covered with a cover glass. Slides were placed on a hot plate for a few seconds in order to remove air bubbles and then placed upside down on a rack while the balsam hardened. Balsam, rather than other mounting media, was used because of its greater permanence. Some of the larger spores were mounted dry in cardboard microfossil slides.

More than 800 slides ${ }^{2 a}$ were made containing microfossils representing about 130 samples from about 2,000 feet of Upper Devonian and Lower Mississippian rocks.

\section{MICROSCOPIC EXAMINATION AND ILLUSTRATION}

The morphological interpretation of compressed plant spores and other microfossils and the mental reconstruction of their original form requires critical lighting and fine focusing. All mounts were studied with transmitted light and some with reflected and polarized light on a Universal microscope at magnifications from $\times 35$ to $\times 1,800$. Most of the specimens required magnifications from $\times 300$ to $\times 800$.

Measurements of individual spores and other microfossils were made with a filar micrometer. All drawings on plate 22 were made at original magnifications of $\times 350$ or $\times 1,000$.

Most of the photographs were taken on 35-mm film at original magnifications of $\times 10$ to $\times 284$. Excellent enlargements as much as $\times 1,000$ could be made without visible grain. The lighting for photography was arranged to emphasize a specific feature or a group of features possessed by the specimen. The nearly opaque and uncompressed specimen shown on plate 4 , figure 5, was centered over a very intense beam of light to show both the ornamentation at the margins and the outline of some features within the margins. Other

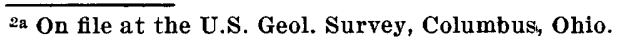


specimens (pl. 7, fig. 1; pl. 8, fig. 4; pl. 20, fig. 8) were also photographed in this manner. The specimen shown on plate 4, figure 1 , was photographed in a completely bright field with the substage condenser racked down. This optical arrangement emphasizes the reiief of the specimen so that surface details are more apparent. Polarized light was used occasionally with specimens of Tasmanites (pl. 20, fig. 4a; pl. 21, fig. 2). If the specimens illustrated on the plates were stained or photographed with filters, such information is noted in the accompanying descriptions.

\section{STRATIGRAPHIC RELATIONS AND SAMPLE LOCALITIES}

\section{GENERAL STRATIGRAPHY}

Upper Devonian and Lower Mississippian rocks crop out in a wide belt extending westward from New York and northern Pennsylvania across northeastern Ohio to Sandusky, Ohio, where the belt swings almost due southward along the eastern flank of the Cincinnati arch and enters northern Kentucky in the vicinity of Vanceburg, Ky. This dominantly marine clastic sequence is generally composed of black to gray and some red shales, siltstones, sandstones, and minor amounts of conglomerate, calcareous shale, and limestone. These beds overlie Middle Devonian limestone and shale and dip gently southward and eastward beneath rocks of younger Mississippian age where these are present and elsewhere beneath rocks of Early Pennsylvanian age.

Upper Devonian and Lower Mississippian rocks are also present, mostly under cover of Pleistocene deposits, in extreme northwestern Ohio on the northwestern flank of the Cincinnati arch, dipping gently southwestward along the Lucas County monocline, and northwestward into the Michigan Basin (Ehlers, Stumm, and Kesling, 1951).

Between the two main outcrop belts mentioned above, but east of the crest of the Cincinnati arch in Logan County, Ohio, is an outlier of Devonian rocks (Bellefontaine outlier) surrounded by rocks of Silurian age.

A brief description of the stratigraphic units sampled during this investigation is given below. The base of the Mississippian is placed at the base of the Bedford shale in accordance with de Witt (1951), Winslow, White, and Weber (1953), Hyde (1953), and Pepper, de Witt, and Demarest (1954).

\section{MIDDLE DEVONIAN STRATA}

The stratigraphy and age relations of the Middle Devonian marine limestones in Ohio, only a few samples of which have been studied during this investigation, have been discussed by Stewart (1955). The Columbus limestone is usually a massive dolomitic brown limestone in the lower part and a very pure light-gray fossiliferous limestone in the upper part. The overlying Delaware limestone is typically a blue limestone interbedded with brown shale and chert layers (Stewart, 1955). Wells (1947) gives a detailed biostratigraphic analysis of these and overlying formations of central Ohio.

\section{UPPER DEVONIAN STRATA}

Overlying the Delaware limestone is the Olentangy shale that is probably of early Late Devonian age. The genetic relation between the Olentangy shale and the overlying Ohio shale is not certain, although Carman (1947) and Wells (1947) suggest that the Olentangy shale of central and southern Ohio is a noncarbonaceous basal phase of the Ohio shale. Typically the Olentangy shale is a slightly calcareous gray-green to blue shale interbedded with layers of black shale and some thin limestones. The shale is sparsely fossiliferous, containing ostracodes, conodonts, plant remains, Tasmanites, corals, bryozoans, brachiopods, and some cephalopods (Wells, 1947).

The overlying Ohio shale is a dominantly black or brownish-black carbonaceous shale interbedded with blue-gray shale, calcareous shale, thin limestones, and some siltstones. The shale thins southward from more than 500 feet in southern Huron County, Ohio, to about 95 feet in Estill County, Ky. (Pepper, de Witt, and Demarest, 1954). In east-central Ohio, the Ohio shale is more than 950 feet thick at locality 7 (fig. 2 and pl. 25) and, including the Chagrin shale, more than 1,500 feet thick at locality 6 (fig. 2 and pl. 24).

The stratigraphic relations of the Huron and Cleveland members of the Ohio shale to the undifferentiated Ohio shale of southem Ohio and to the Chagrin shale of northeastern and east-central Ohio are not completely known. The shales of the Huron and Cleveland members interfinger with, and are correlative in age, in part, to the Chagrin shale.

The lower member of the Ohio shale, the Huron member, where characteristically developed in the bluffs of the Huron River, north of Norwalk, Ohio, is a grayish-black shale fissile shale containing many large concretions. Here the immediately overlying upper member of the Ohio shale, the Cleveland member, is lithologically similar, but differs in that it contains thin beds of gray shale, siltstone, and siliceous limestone in the lower part. Eastward the tough grayishblack shale of the Cleveland interfingers with the Chagrin shale, thinning to a feather edge in eastern Ashtabula County (Pepper, de Witt, and Demarest, 1954). In central and northern Ohio the black shales of the Huron and Cleveland members are roughly equivalent in age to the lithologically undifferentiated Ohio shale of southern Ohio and are separated in some areas by 
the gray Chagrin shale. The Chagrin shale of eastern Ohio may include as much as 1,200 feet of interbedded massive gray siltstone and shale; westward the Chagrin shale has a lower silt content; it thins and interfingers with the Ohio shale. Fossils in the Ohio shale, generally scarce, include fish remain, conodonts, scolecodonts, brackish-water brachiopods, Tasmanites, foerstian algal(?) remains, and fragments of other plants. The massive siltstones of the Chagrin shale in northeastern Ohio are generally very fossiliferous.

\section{MISSISSIPPIAN STRATA}

The contact of the Upper Devonian black shale with the overlying Lower Mississippian Bedford shale is usually distinct except in a few areas, such as the Cleveland area where a dark-gray to black fossiliferous zone occurs at the base of the Bedford shale. The Bedford shale is usually a red argillaceous shale, gray in the basal part, interbedded with thin partings of ripplemarked siltstone in some areas. Near Cleveland, Ohio, two massive beds, the Euclid and Sagamore siltstone members, occur in the Bedford shale. The thickness of the Bedford shale in northern Ohio is irregular because of post-Bedford channel scouring. Southward through Ohio the Bedford shale thins and becomes more silty, and in addition decreases in red shale content. The Bedford shale contains few invertebrate marine fossils other than those in the basal transitional zone in northern Ohio; fragmental plant remains are common in the shale in northern Ohio (pl. 2, figs. $2,2 \mathrm{a}, 3)$.

In central and northern Ohio the Bedford shale is generally overlain disconformably by the Berea sandstone. In southern Ohio the siltstones of the Bedford shale cannot be distinguished from those of the Berea sandstone. The Berea sandstone is a medium- to finegrained quartzose sandstone that in northern Ohio may occur as a massive channel sandstone, as a crossbedded sandstone, or as a thin-bedded marine sandstone. In many places the basal part of the Berea sandstone occurs in channels cut into, or through, the Bedford shale. One such channel sandstone, in the vicinity of South Amherst, Ohio (loc. 5), is as much as 235 feet thick. Pepper, de Witt, and Demarest (1954) observed rery few invertebrate fossils in the Berea sandstone, these occurred in the sandstone near the Ohio-Pennsylvania State line. Carbonaceous material is very common, especially in the channel sandstone phases in northern Ohio (pl. 2, fig. 1). In east-central Kentucky the Bedford shale and Berea sandstone feather out, and there younger beds of the black Sunbury shale rest directly on the black Ohio shale.

The Sunbury shale is a black fissile shale, contains highly comminuted organic matter, is somewhat quartz- ose, pyritic, and fossiliferous in the basal part, and is generally similar in appearance to the Cleveland member of the Ohio shale. The shale is generally thickest in eastern Kentucky, western West Virginia, and southern Ohio; it is a sharply distinguishable unit throughout Ohio except in much of northern Ohio, east of Cleveland, where it is considered the basal member of the Orangeville shale. The Sunbury member is not recognized in extreme northeastern Ohio.

The overlying Cuyahoga formation consists of about 150-300 feet of marine shales and fine-grained sandstones displaying a complex pattern of facies changes. In northern Ohio the Cuyahoga has a group status and is recognized as including three formations, the Orangeville shale, the Sharpsville sandstone, and the Meadville shale in ascending order. The Cuyahoga group is overlain disconformably by Pennsylvanian rocks in northern Ohio, but in central and southern Ohio the Cuyahoga formation is overlain by the Black Hand formation.

The Black Hand formation consists of massive coarsegrained sandstone and some conglomerate in the lower 50-210 feet and of fine- to coarse-grained sandstone in the upper 60-130 feet. Hyde (1953) contrasts the complex facies changes evident in the lower part of the Black Hand formation to the widespread areal uniformity of the upper part (the Byer and Allensville members of the Logan formation of Hyde, 1912, 1915, 1953 ) of the Black Hand formation.

The Logan formation (Vinton member of the Logan formation of Hyde, 1912, 1915, 1953) is finer grained than, and usually easily distinguishable from, the underlying beds of the Black Hand formation. The Logan formation usually consists of a series of finegrained gray to yellow sandstones and shales with a maximum thickness of 200-240 feet.

An erosion surface separates the Logan formation from the overlying Maxville limestone of Mississippian age. The Mississippian rocks as a whole were deeply eroded prior to the deposition of sediments during Pennsylvanian time.

\section{SAMPLING LOCALITIES}

Localities where samples were collected are indicated by number on the index map of Ohio (fig. 2). Measured sections are given for the outcrops at localities 1 , 2, and 9. Distinction of the lithologic units and sample descriptions for localities $6,7,8$, and 10 are based on observation of core and cutting chips under a binocular microscope.

\section{LOCALITY 1}

Chippewa Creek section (pl. 1) was measured 0.6 mile east of Brecksville on the north side of Chippewa Creek in the Brecksville Reservation, a part of the 


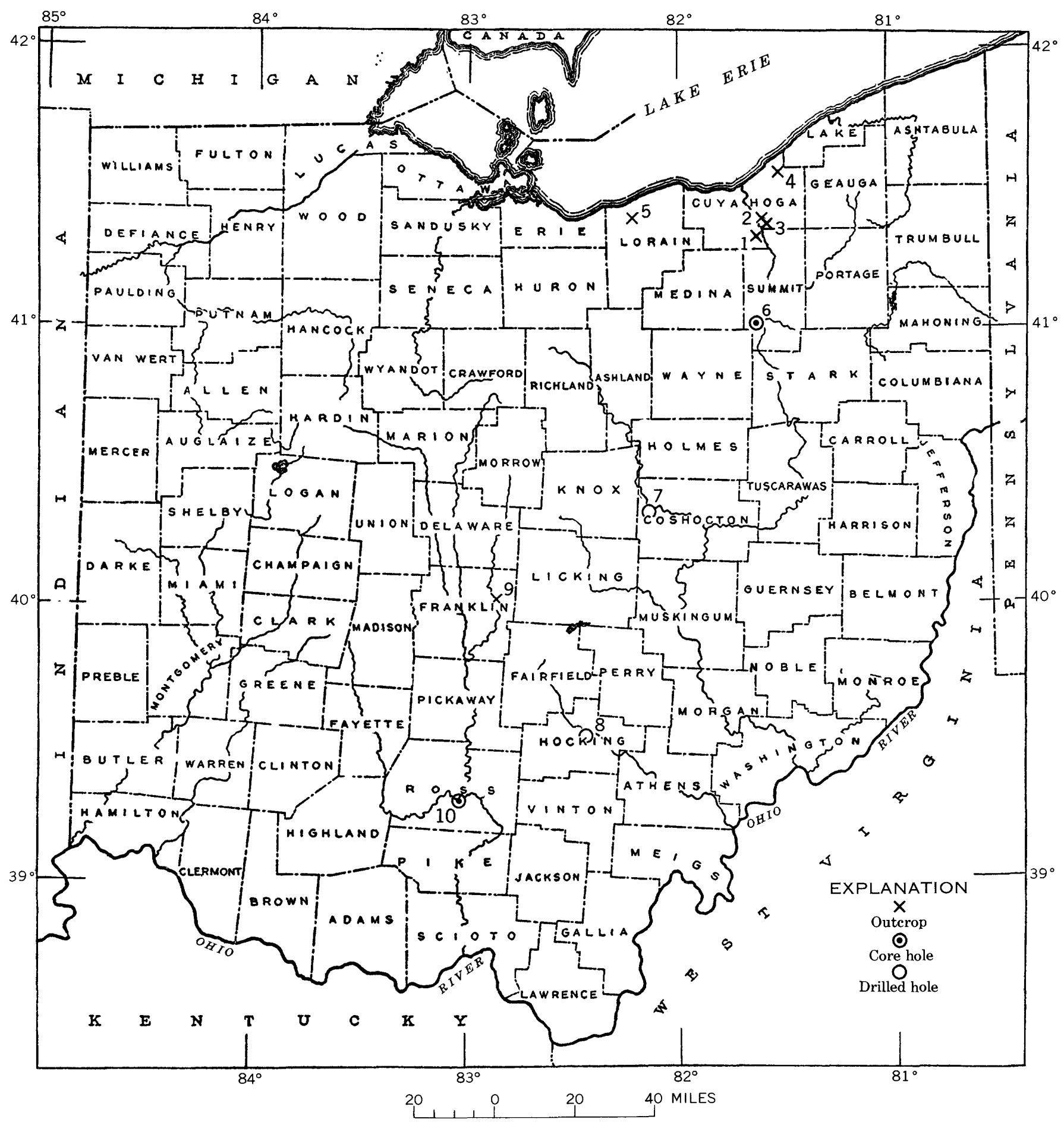

Figure 2.-Index map of ohio showing general location of collecting localities.

Cleveland Municipal Park System, Brecksville Township, Cleveland quadrangle, Cuyahoga County, Ohio (SW1/4NE1/4 T. 5 N., R. 12 W.). A description of the stratigraphic sequence near this section is given by Prosser (1912, p. 441). De Witt (1951, p. 1353) mentions that the base of the Bedford shale is black or very dark gray in the Cleveland area and can be separated from the Cleveland member of the Ohio shale only by means of fossils. This basal fossiliferous zone was not noted at locality 1 . It is possible that the sample (maceration $158^{3}$ ) supposedly taken from the upper 2 inches of the Cleveland is actually basal Bedford shale. Section begins at creek bottom 100 feet south of State Route 82.

Samples macerated for study for this report are indicated by maceration numbers. Letters following maceration numbers in the following stratigraphic section correspond to those used on pl. 1 . 
Level of State Route 82.

Lower Mississippian :

Berea sandstone:

6. Sandstone, gray, coarse-grained, massive, Feet cliff-former, based covered. Maceration 304

$20 \pm$

Total exposed thickness of Berea sandstone

Disconformity.

Bedford shale :

Unnamed unit:

5. Shale, red and gray to blue, argillaceous, and fine-grained siltstones, thinly laminated, partly covered. Maceration 305 from red shale $18 \mathrm{ft}$ below base of Berea sandstone

Euclid siltstone member :

4. Siltstone, gray, medium- to thin-bedded, some shale layers near base. Designated "Euclid sandstone" by Prosser (1912, p. 442). Maceration 162 (pl. 1, $A$ ) from basal shale and two 2-in. siltstone layers beneath this shale at base of Euclid siltstone member.

Unnamed unit:

3. Shale, gray, thin-bedded, some siltstone layers. Macerations: $40 \mathrm{~A}, \mathrm{~B}$, and $\mathrm{C}$ (pl. 1, B) from top 2 in. of shale below base of Euclid; 160 (pl. 1, $C$ ) from shale $3 \mathrm{ft}$ below base of Euchid; 38 ( $\mathrm{pl}$. $1, D$ ) from shale 1-5 (?) ft below base of Euclid; 320 (pl. 1, E) from basal 4-6. in. of Bedford shale; 61-1, 61-2 (pl. 1, $E$ ) from basal 2 in. of Bedford shale_-

Total thickness of Bedford shale

$\begin{array}{r}8 \\ \hline 59\end{array}$

Upper Devonian :

Ohio shale :

Cleveland member :

2. Shale, uniformly black, massive, fissile when weathered. Two thin soft gray shales near base at position marked by $I$ on pl. 1. Macerations : 158 (pl. $1, F$ ) from top 2 in. of Cleveland; 39 and 150 (pl. 1, $G$ ) from shale $15 \mathrm{ft}$ above base of Cleveland; 157B (pl. 1, I) from two soft gray layers above and below sample $157 \mathrm{~A} ; 157 \mathrm{~A} \mathrm{(pl.} 1, H$ ) from black shale $2 \frac{1}{2}$ ft above base, between two soft gray shale layers; 152 (pl. $1, J$ ) from shale 3 in. above base of Cleveland; 156 (pl. 1, $K$ ) from basal $2 \frac{1}{2}$ in. of shale

Total thickness of Cleveland member---- 25

Chagrin shale :

1. Shale, gray, poorly bedded, some thin silty layers, pyritic, fossiliferous (brachiopods). Maceration 154 (pl. 1, $L$ ) from top 8 in. of Chagrin shale

Total exposed thickness of Chagrin shale_-_-- 7

Bed of Chippewa Creek:

Total exposed thickness of section...- 111士

\section{LOCALITY 2}

Section is along north side of Tinkers Creek, along Button Road, 1.5 miles southwest of Bedford, Bedford Township, Cleveland quadrangle, Cuyahoga County, Ohio (NE1/4 NW1/4SW1/4 T. 6 N., R. 11 W.). Approximately the same section is described by Prosser (1912, p. 406-407).

Covered.

Lower Mississippian :

Bedford shale:

Sagamore siltstone member :

3. Siltstone gray, thin- to medium-bedded, some shale layers near base of unit. Twelve-in. shale layer above basal 4-in. siltstone layer of Sagamore included in maceration 163

Unnamed unit:

2. Shale and siltstone, blue-gray, evenly bedded, some crossbedding (pl. 2, fig. 3 ). Interval 3.5-4 ft below base of Sagamore siltstone member included in maceration 161. Sample taken $11.5 \mathrm{ft}$ below base of Sagamore included in maceration 159 (hand specimens shown on pl. 2, figs. 2, 2a, 3)

Total exposed thickness of Bedford shale $50 \pm$

Upper Devonian:

Ohio shale :

Cleveland member :

1. Shale, black, massive, band of vitrain 5 ft long and a few inches thick near base. Contact of Cleveland with Bedford shale covered. Basal 6 in. of black shale in-

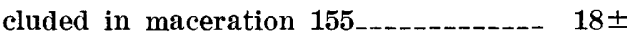
Total thickness of Cleveland member_--- $18 \pm$

Chagrin shale:

Total thickness of section sampled _..- $68 \pm$

\section{LOCALITY 3}

Sample was taken along west bank of sewer outlet, north side of Tinkers Creek, Bedford Glens, 0.5 mile south of Bedford, Bedford Township, Cleveland quadrangle, Cuyahoga County, Ohio (NE1/4NE $1 / 4 \mathrm{SW}^{1} / 4 \mathrm{~T}$. 6 N., R. 11 W.). The stratigraphic sequence at this locality is described by Prosser (1912, p. 408, 409). Silty layers of Bedford shale, $6 \mathrm{ft}$ below the base of the Berea sandstone were included in macerations 278 and 306. The total thickness of the Bedford shale in this section is about 88 feet. Therefore, the sample macerated would represent uppermost Bedford shale.

\section{LOCALITY 4}

Sample is from the bed of Euclid Creek at base of a hill known as Old Baldy about 0.5 mile south of U.S. Highways 6 and 20, Euclid Township, Euclid quadrangle, Cuyahoga County, Ohio (center of R. 11 W., 
T. 8 N.). Sample is from a fossiliferous bed (sponges) in the gray Chagrin shate about 130 feet below the base of the Cleveland member of the Ohio shale. The shale matrix is light gray, poorly bedded, fossiliferous, and pyritic, and appears devoid of plant remains. This sample was included in maceration 169.

\section{LOCALITY 5}

Samples are from the Berea sandstone in the Cleveland Quarries Co.'s Quarry 6, north of U.S. Highway 113, South Amherst, Amherst Township, Vermillion quadrangle, Lorain County, Ohio (Center of SW1/4 SW1 14 T. 6 N., R. 18 W.). In this area the Berea sandstone is in the form of channel sandstone and may be as much as 235 feet thick (Pepper, de Witt, and Demarest, 1954, p. 28). These authors emphasize that much of the carbonaceous material included in the Berea sandstone occurs in the channel sandstone depositional phases of the Berea. The macerated sample is a very carbonaceous sandstone (pl. 2, fig. 1) and is included in macerations 153 and 302 .

\section{LOCALITY 6}

Barberton test core 3 was drilled for mine-shaft exploration for the Pittsburgh Plate Glass Co. (Columbia Chemical Division) about 2 miles west of the center of Barberton, Norton Township, Akron quadrangle, Summit County, Ohio (center of NE1/4 SW1/4 T. 1 N., R. 12 W.). The stratigraphic succession to a depth of about 2,800 feet is as follows: Deposits of Pleistocene age; Sharon conglomerate of Pennsylvania age; Cuya- hoga formation, Sunbury shale, Berea sandstone, and Bedford shale of Mississippian age; Cleveland member of Ohio shale, Chagrin shale, Huron member of Ohio shale, and Olentangy shale of Late Devonian age; Delaware and Columbus limestones, Lucas dolomite, and Sylvania sandstone of Middle Devonian age; Bass Island dolomite and Salina formation of Silurian age.

Stauffer (1944) compiled a $\log$ of this succession based on a study of the section exposed in the mine shafts and on a study of the cores of wells 3 and 4 . In general his interpretation of formational boundaries has been followed in this study. W. H. Hass made his unpublished $\log$ of core 3 available for this study.

Parts of the original core as well as a split, deposited at the Geological Survey laboratory at Columbus for trace elements analysis and paleobotanical research, were examined and sampled by the author as follows: 468-1,497 feet (including rocks from the lower part of the Cuyahoga formation down nearly to the base of the foerstian zone in the Huron member of the Ohio shale) ; 1,700-2,067 feet (lower part of Huron member and upper part of Olentangy shale); 2,181-2,209 feet (basal part of Olentangy shale, Delaware limestone, and upper part of Columbus limestone). Two hundred feet of the Huron member below the foerstian zone and about a hundred feet of the lower part of the Olentangy shale were not examined for microfossils.

As a whole the Upper Devonian shales are not conspicuously demarcated lithologically as typical Cleveland nember, Chagrin shale, and Huron member. The thickness of the rock units is, therefore, for the most part, that given by Stauffer (1944).

Lower Mississippian:

Cuyahoga formation (lower $17 \mathrm{ft}$ ):

Depth $468-485$

11. Shale, medium-gray

Description

Depth
$($ feet $)$

$468-484$

Sunbury shale:

10. Shale, gray to black, silty. Lingula in basal 6 in

Description

Depth

$($ feet $)$

436

Maceration No.

Black silty shale

Berea sandstone (not reported by Stauffer [1944]):

9. Sandstone, light-buff to gray, petroliferous

$\begin{array}{ccc}\text { Mfaceration No. } & \text { Description } & \begin{array}{c}\text { Depth } \\ \text { (feet) }\end{array} \\ 508.25\end{array}$

Bedford shale:

8. Siltstone, light- to medium-gray. Marine fossils in lower $10 \mathrm{ft}$ of coarser grained siltstone. Carbonaceous bands and spores conspicuous.

Description

Light-gray siltstone and medium-gray shale containing spores

438

Maceration No.

Interbedded medium-gray siltstone and shale containing spores
$507.75-509.16$

$485-507.75$

509. 16-562. 75
Depth
$($ feet $)$
510

527 
Upper Devonian:

Ohio shale:

Cleveland member:

7. Siltstone, dark- to light-gray, sandy, with dark-gray shale in lower $20 \mathrm{ft}$. Lingula at $585 \mathrm{ft}$.

Carbonaceous layers present

\section{Description}

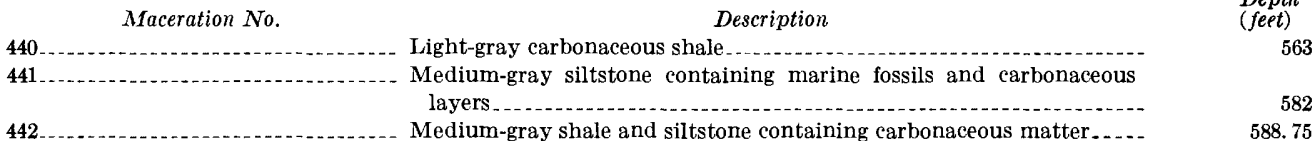

Chagrin shale:

6. Shale and siltstone, medium- to dark-gray with a few sandy beds and carbonaceous layers. Scolecodonts abundant. Marine fossils at 640,720 , and $740 \mathrm{ft}$

\begin{tabular}{|c|c|c|}
\hline Maceration No. & Description & $\begin{array}{l}\text { Depth } \\
\text { (feet) }\end{array}$ \\
\hline & Medium- and light-gray siltstone, carbonaceous & 639.75 \\
\hline & Medium-gray siltstone, carbonaceous & 664.5 \\
\hline 5.. & Medium- to dark-gray siltstone, carbonaceous............. & 708.6 \\
\hline & Gray siltstone, containing megaspores...................... & 708. 75-713. 5 \\
\hline $44-1-B_{2}$ & Medium-gray siltstone containing megaspores_....... & $792-797$ \\
\hline & Gray carbonaceous siltstone & 796. 6 \\
\hline . & Mottled red and gray siltstone & 832-836. 1 \\
\hline
\end{tabular}

622. $75-836.16$

5. Shale, black in upper $25 \mathrm{ft}$, and siltstone, medium- to reddish-gray with carbonaceous layers. Calcareous in lower part . .

\begin{tabular}{|c|c|c|}
\hline Maceration No. & Description & $\begin{array}{l}\text { Depth } \\
\text { (feet) }\end{array}$ \\
\hline $119 \ldots \ldots \ldots$ & Light-gray shale & $919-924$ \\
\hline 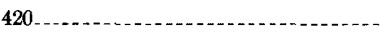 & Gray carbonaceous siltstone containi & $973-978$ \\
\hline $421 \ldots$ & Gray silty shale containing Tasmanites....... & 987. 6-993 \\
\hline & Gray siltstone and shale containing Dicrospor & $1,027-1,032$ \\
\hline & Gray siltstone and shale, carbonaceous, containing megaspores... & $059.5-1,062.3$ \\
\hline
\end{tabular}

836. $16-1,082.75$

Ohio shale:

Huron member:

4. Siltstone, medium- to dark-gray and black, interbedded with calcareous layers, gray shale, and blue-gray siltstone. Marine fossils at 1,300,1,540,1,900, and 1,975 ft. Tasmanites especially abundant from 1,753-1,875 ft. Foerstians present from 1,436.5-1,519 ft

1, 082. 75-2, 071. 75

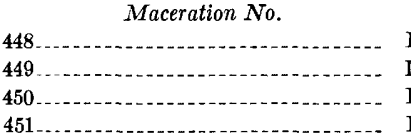

Description

ight-gray shale containing Themenites....

Interbedded gray shale and siltstone containing foerstians

Dark-gray siltstone containing abundant Tasmanites

Dark-gray shale containing Tasmanites

Olentangy shale:

3. Siltstone and shale, medium-gray to black, interbedded with thin brown limestone layers.

Tentaculites, brachiopods, conodonts, ostracodes, and Tasmanites common.

$\begin{array}{ccrc}\text { Maceration No. } & \text { Description } & \begin{array}{r}\text { Depet }) \\ (\text { jeet }\end{array} \\ 452 & \text { Black shale }\end{array}$

Middle Devonian:

Delaware limestone:

2. Limestone, dark-gray

Columbus limestone:

1. Limestone, light-gray, with black shale partings in upper $30 \mathrm{ft}$

Description

453

Maceration No.

Black shale partings

Lucas dolomite:

Total thickness of section sampled, $1,738.8 \mathrm{ft}$.

\section{LOCALITY 7}

R. J. Dalier No. 3 well was drilled (cable tool) by the Pure Oil Co. on the R. J. Dalier farm about 1.4 miles southeast of Newcastle, Newcastle Township, Brinkhaven quadrangle, Coshocton County, Ohio (E1/2NE1/4 SE1/4 SW1/4 R. 9 W., T. 6 N.). Drilling began at an elevation of 1,160 feet, cuttings being re- covered by bailer at intervals of 4 to 20 feet below a depth of 220 feet, and terminated in rocks of Silurian age (the Clinton sand of drillers) at a depth of more than 3,200 feet. The $\log$ of the Mississippian rocks cut by this well is given and discussed by Lamborn (1954, p. 226-227). The Cuyahoga and Black Hand formations (undifferentiated) are reported as a single 
unit because the lower part of the Black Hand formation is not characteristically developed at this locality. The upper limit of the Black Hand formation is placed at the upper limit of the Allensville(?) member of the Logan formation of Hyde $(1912,1915,1953)$ as reported by Lamborn (1954, p. 226).

Cuttings from the following formations were examined for microfossils: Logan formation, Black Hand and Cuyahoga formations (undifferentiated), Sunbury shale, Berea sandstone, and Bedford shale of Mississippian age; Ohio and Chagrin shales (undiffereniated) and Olentangy shale of Late Devonian age; Middle Devonian "Big Lime" (Delaware limestone, Columbus limestone, and Detroit River group) and "Oriskany sand" (Sylvania sandstone).

Loss of interval.

Lower Mississippian:

Logan formation:

12. Sandstone, siltstone, and shale, gray to dark-gray and buff. Marine fossils present in finer grained calcareous beds; carbonaceous matter and megaspores conspicuous in coarse-grained beds.

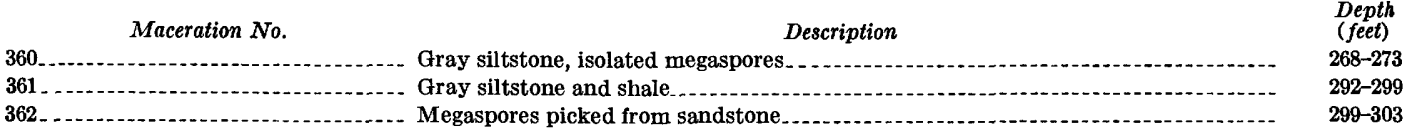

Black Hand and Cuyahoga formations, undifferentiated:

11. Sandstone and siltstone, buff to gray, shale, usually gray. Sandy beds predominating from 370-470 ft and from 650-700 ft. Marine fossils present at about $400 \mathrm{ft}, 600 \mathrm{ft}, 680 \mathrm{ft}$ and common in lower 150 ft of gray shale.....

\begin{tabular}{|c|c|c|}
\hline Maceration No. & Description & $\begin{array}{l}\text { Depth } \\
(\text { feet })\end{array}$ \\
\hline cos & Isolated megaspores & $452-460$ \\
\hline - & Gray and buff coarse siltstone & $452-460$ \\
\hline .... & Sandstone, disaggregated, isolated megaspores.............. & $460-468$ \\
\hline & Siltstone, carbonaceous, megaspores...-............. & $650-665$ \\
\hline & Gray silty shale containing megaspores......... & $722-730$ \\
\hline
\end{tabular}

Sunbury shale:

10. Shale, black to dark-gray, dense, containing quartz grains in basal layers

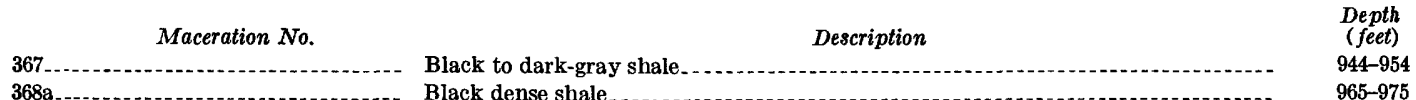

Berea sandstone:

9. Sandstone, coarse-grained, pyritized

\begin{tabular}{|c|}
\hline Maceration No. \\
\hline
\end{tabular}

Bedford shale:

8. Siltstone, gray, and shale, gray to black. Marine fossils at $990 \mathrm{ft}$. Black shale containing Tasmanites prevalent in lower $52 \mathrm{ft}$

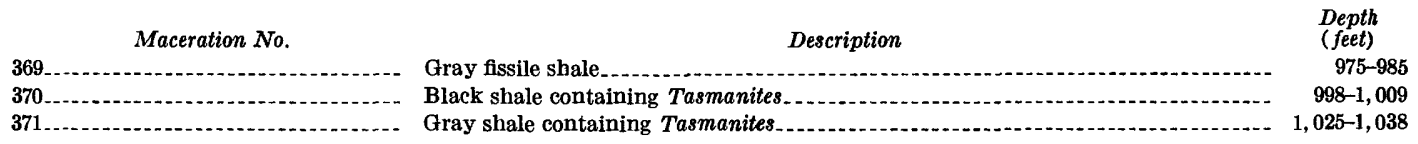

Upper Devonian:

Ohio and Chagrin shales, undifferentiated:

7. Shale, black and dark-gray, containing abundant Tasmanites. Marine fossils at 1,060 ft _.

6. Siltstone and shale, gray, containing Tasmanites

$\begin{array}{cccc}\text { Maceration No. } & \text { Description } & \text { Depth } \\ (\text { feet })\end{array}$

5. Shale, light- to dark-gray, containing Dicrospora spores.

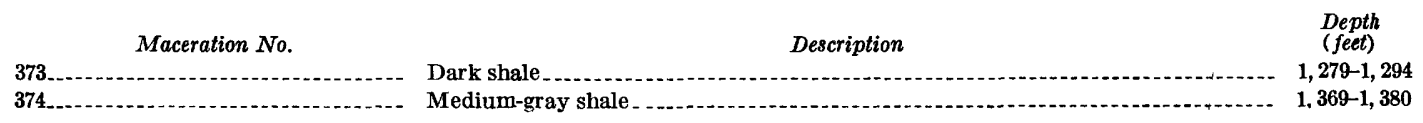

4. Shale, buff to dark-gray, with interbedded light-gray siltstone 
Upper Devonian-Continued

Ohio and Chagrin shales, undifferentiated-Continued

3. Shale, black, interbedded with gray and blue-gray shale. Three thin limestone layers between 1,670

Depth and 1,700 ft. Foerstians present at 1,640-1,740 ft. Tasmanites abundant in lower $65 \mathrm{ft}$

Maceration No.
375 ...
376
378

\begin{tabular}{|c|c|c|}
\hline & Description & $\begin{array}{l}\text { Depth } \\
\text { (feet) }\end{array}$ \\
\hline ark-gray to black shale & & $1,571-1,582$ \\
\hline hale containing foerstians & & $1,729-1,740$ \\
\hline shale containing Tasmanites & & $1,849-1,859$ \\
\hline k shale containing abundan & Ta & $1,979-1,994$ \\
\hline
\end{tabular}

Olentangy shale:

2. Shale, blue-gray, interbedded with black and calcareous brown shale and gray siltstone. Marine fossils at 2,100 ft. Tasmanites abundant near base

$$
389
$$

Maceration No.

Gray shale containing Tasmanites

Description

Brown calcareous shale containing Tasmanites

Depth

$2,017-2,030$

$2,183-2,193$

Middle Devonian:

"Big Lime" (Delaware limestone, Columbus limestone and Detroit River group):

1. Limestone, brown, and dolomite, interbedded with gray to black shale (cavings?) containing Tasmanites.

Marine fossils and fish remains present.

Maceration No.

Description

Depth

381

Maceration $N$

Dark shale containing Tasmanites

"Oriskany sand" (Sylvania sandstone).

Total thickness of section sampled, $2,080 \mathrm{ft}$.

\section{LOCALITY 8}

The Mounts No. 1 well was drilled by W. C. Adair and Co. (cable tool) about 3.2 miles south of Logan and 0.5 mile east of Scott Creek, Falls township, Zaleski quadrangle, Hocking County, Ohio (NW1/4 SE1/4 SE1/4, sec. 35, R. 17 W., T. 14 N.). Drilling began at an elevation of 920 feet in rocks of Pennsylvanian age, cuttings being recovered by bailer at intervals of 5 to
15 feet, and terminated at a depth of 2,826 feet in Silurian rocks. The stratigraphic sequence with which this report is concerned is: Cuyahoga formation (lower $27 \mathrm{ft}$ ), Sunbury shale, Berea sandstone, and Bedford shale of Mississippian age; Cleveland member of Ohio shale, Chagrin shale, Huron member of Ohio shale, and Olentangy shale of Late Devonian age.

Lower Mississippian:

Cuyahoga formation (lower $27 \mathrm{ft}$ ):

8. Shale, light- to medium-gray, containing spores, conodonts, scolecodonts, and crinoid stems

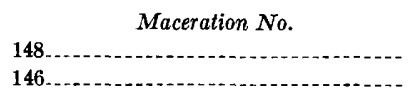

Sunbury shale:

7. Shale, black to dark-gray, containing a few beds of light siltstone and quartz grains at base

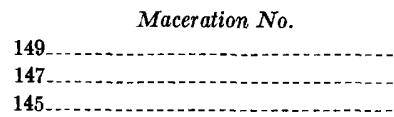

$$
\begin{aligned}
& \text { Black to dark-gray shale } \\
& \text { Black shale }
\end{aligned}
$$

Description

Black to dark-gray shale.

Berea sandstone:

6. Sandstone, quartzose, very coarse to very fine grained

5. Shale and siltstone,red, interbedded with gray shale, often in very thin laminae, containing carbonaceous matter and spores. Carbonaceous matter in red beds often surrounded by gray reduction aureoles. Few shell fragments at base
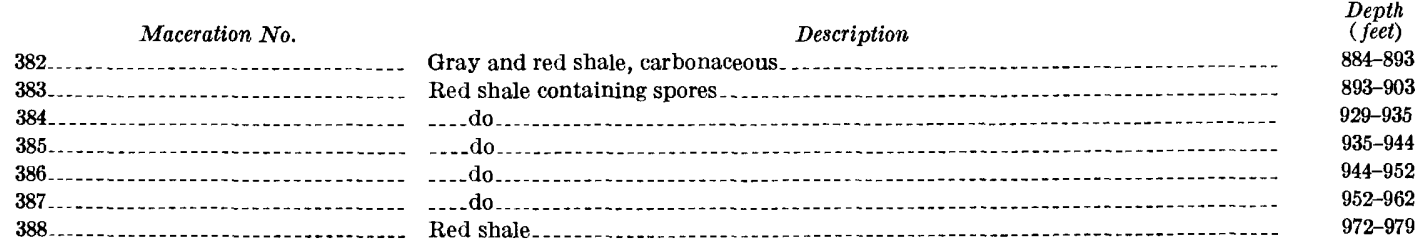
Upper Devonian:

Ohio shale:

Cleveland member:

4. Shale, black to brown, containing abundant Tasmanites and a few conodonts

Maceration No.

Description

Depth
$($ feet $)$

$1,007-1,015$

Chagrin shale:

3. Shale, light- to medium-gray, interbedded with some dark-gray shale, especially near base and with lightgray siltstone in upper $30 \mathrm{ft}$. Contains spores, carbonaceous matter, some conodonts and Tasmanites_- 1,044-1, 290

$\begin{array}{ccc}\begin{array}{c}\text { Maceration No. } \\ \text { Unmacerated sample }\end{array} & \begin{array}{c}\text { Depth } \\ (\text { feet })\end{array} \\ 390 & \text { Triletes }\end{array}$

Ohio shale:

Huron member:

2. Shale, black, dark-gray and light-gray. Black shale most prominent in upper $15 \mathrm{ft}$ and in lower 255 ft. Conodonts present at top and fish fragments scattered throughout. Tasmanites especially abundant in basal $200 \mathrm{ft}$. Foerstians and thin calcareous shales from 1,430-1,571 $\mathrm{ft} \ldots \ldots$

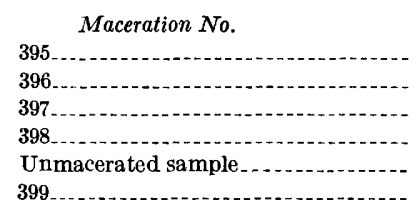

\begin{tabular}{|c|c|}
\hline Description & (feet) \\
\hline Dark-gray shale containing Tasmanites -- & $1,290-1,296$ \\
\hline Medium-gray shale containing foerstians....... & $1,430-1,443$ \\
\hline Black shale containing foerstians & $1,504-1,514$ \\
\hline Black shale containing foerstians and Tasmanites....... & $1,543-1,558$ \\
\hline Tasmanites & $1,628-1,642$ \\
\hline
\end{tabular}

Olentangy shale:

1. Shale, light- to medium-gray and blue-gray interbedded with calcareous shale and buff limestone. Black to brown shale in basal $30 \mathrm{ft}$. Tasmanites abundant, ostracodes and crinoids present

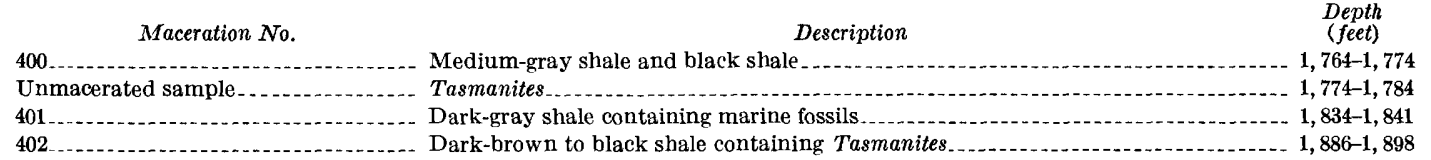

Middle Devonian rocks.

Total thickness of section examined for samples, $1,122 \mathrm{ft}$.

\section{LOCALITY 9}

Samples were taken of the Bedford shale exposed in the Claycraft Co. clay products pit 1.25 miles east of the juncture of Morrison Road and State Route 317, east of Big Walnut Creek, Jefferson Township, East Columbus quadrangle, Franklin County, Ohio (SE1/4 NW1/4 SW $1 / 4$ T. 1 N., R. 16 W.). Additional samples were taken of the Bedford shale, Berea sandstone, and Sunbury shale along Rocky Fork, 1.25 miles east of Gahana, Jefferson Township, Westerville quadrangle, Franklin County, Olio $\left(\mathrm{S}_{1} / 2 \mathrm{SW}^{1} / 4 \mathrm{NW}^{1} / 4\right.$, T. $1 \mathrm{~N}$., R. 16 W.).

Stauffer, Hubbard, and Bownocker (1911, p. 220-221) give a composite section of the stratigraphic units in this locality along Rocky Fork from its juncture with Big Walnut Creek to the upper part of the tributary which flows through New Albany. Their section is adopted, in part, as no attempt was made to measure the section when the collections were made.
Lower Mississippian :

Cuyahoga formation:

Sunbury shale :

Feet 12. Covered unit_-___-_-_- 10.0

11. Shale, black, fissile, iron-stained. Brachiopods, conodonts, and fish plates abundant in basal few inches. Basal 8 in. included in maceration 151

Total thickness of Sunbury shale. 35.6

Berea sandstone :

10. Sandstone, massive, ripple marked. Laminated siltstone and sandstone $12.3 \mathrm{ft}$ below top included in maceration $\mathbf{3 1 7}$

9. Sandstone, fine-grained, interbedded with shales, ripple marked._._..............

8. Shale, gray, arenaceous, interbedded with sandstone.

7. Zone of convolute bedding. Light sandy siltstone, crossbedded, from basal 6 in., included in maceration 315._- 1.0

Total thickness of Berea sandstone.--- 39.0 
Lower Mississippian-Continued

Bedford shale:

6. Shale, blue, argillaceous, arenaceous toward top, soft. Dark-gray shale from upper 6 in. included in maceration 318; arenaceous ripple marked shale $10 \mathrm{ft}$ below base of Berea sandstone included in macerations 316 and 319 ; gray shale $20 \mathrm{ft}$ below base of Berea sandstone included in maceration 314

5. Shale, mottled-gray, argillaceous, soft

4. Shale, red to reddish-brown, fissile. Red shale at base of unit included in maceration 312

3. Shale, blue, argillaceous, fissile, soft. Blue shale at top of unit included in maceration 313

2. Shale, blue, argillaceous, very fossiliferous near base

1. Shale, dark-bluish-brown, soft, sparsely fossiliferous

Total thickness of Bedford shale
Upper Devonian :

Ohio shale.

\section{LOCALITY 10}

The Chillicothe test core was drilled 2.5 miles southwest of Chillicothe, northeast corner Huntington Township, Roxabell quadrangle, Ross County, Ohio (lat $39^{\circ}$ $17^{\prime} 57^{\prime \prime} \mathrm{N}$., long $83^{\circ} 01^{\prime} 05^{\prime \prime} \mathrm{W}$.). Test coring began at an elevation of 880 feet south of Paint Creek, penetrating Sunbury shale, Berea sandstone, and Bedford shale of Mississippian age; Ohio shale and Olentangy shale of Late Devonian age; and Columbus limestone of Middle Devonian age. Coring terminated in rocks of Silurian age at 577 feet. Descriptions and interpretations of the beds cut by the core are given by Car$\operatorname{man}(1947,1955)$.

Of the available core, only parts of the Ohio and Olentangy shales, 440 feet in total thickness, were examined.

Lower Mississippian:

Bedford shale.

Upper Devonian:

Ohio shale:

2. Shale, black to brown, interbedded with light-gray shale. Darker shale and calcareous beds prominent near top. Lingula present near top and at several lower horizons. Foerstians present from 320-376.75

ft. Tasmanites abundant

Maceration No.

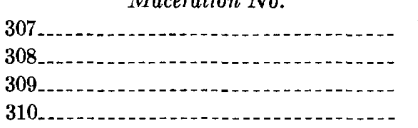

\begin{tabular}{|c|c|}
\hline \multirow{2}{*}{$\begin{array}{r}\text { Description } \\
\text { Pate }\end{array}$} & $\begin{array}{l}\text { Depen } \\
(\text { feet })\end{array}$ \\
\hline & 125.25 \\
\hline Blue-gray shale containing Tasmanites _.... & 218 \\
\hline 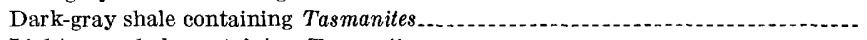 & 399.25 \\
\hline Light-gray shale containing Tasmanites & 466.3 \\
\hline
\end{tabular}

Olentangy shale:

1. Shale, blue-gray, interbedded with brown to black shale, especially in basal $5 \mathrm{ft}$. Lingula present at

base. Tasmanites abundant.

500. $5-564.5$

311

Maceration No.

Description

Depth
(feet)

Black shale containing Tasmanites

Middle Devonian:

Columbus limestone.

\section{MISCELLANEOUS SAMPLES}

A number of samples of Pleistocene till from the Great Lakes region were examined for their content of secondarily deposited Devonian and Mississippian age plant spores and Tasmanites microfossils.

Samples of black shale of Late Devonian age from States adjacent to Ohio were examined for Tasmanites.

The following additional samples of Columbus limestone of Middle Devonian age were macerated and examined: Core chips of black shale partings from Marblehead Peninsula on Lake Erie; limestone from the upper part of the formation from Bellevue quarry, south of Sandusky, Ohio, and Marblehead peninsula.

\section{MICROFOSSIL OCCURRENCE AND DISTRIBUTION}

\section{STRATIGRAPHIC OCCURRENCE}

\section{MIDDLE DEVONIAN STRATA}

Only a few microfossils have been recovered from marine Middle Devonian beds (miscellaneous samples and loc. 7): Tasmanites sinuosus and Cirratriradites sp. A. The latter was noted only in well cuttings. Tasmanites or Tasmanites-like microfossils were previously known to occur in the Middle Devonian limestones (oral communication, C. H. Summerson, 1955). 
Although the present writer did not find Dicrospora represented, one spore, possibly referable to this genus, was found by J.W. Wells (written communication, $1955)$ in the Columbus limestone.

\section{UPPER DEVONIAN STRATA}

The Olentangy shale is almost devoid of land-plant spores. Dicrospora multifurcata and Cirratriradites sp. A are sparsely represented only in well cuttings from locality 8. Tasmanites, however, is represented abundantly, especially by some of the thick-walled disseminules of T. huronensis, T. sp. A, and T'. sommeri. Only a few hystrichosphaerids are present. Thus, in a depositional environment that Wells (1947) considers as normally saline and below wave base, Tasmanites is dominant.

Microfossil assemblages in the lower part of the Ohio shale, or lower part of the Huron member where differentiated, usually contain many thick-walled disseminules of Tasmanites sommeri. T. sinuosus is commonly dominant. Several dicrosporoid spores are present below the foerstian zone.

Foerstian remains occur within the lower part of the Ohio shale, or Huron member, throughout a zone ranging from 60 to 150 feet in thickness (fig. 3), a zone remarkably persistent in lateral extent and possibly representing a correlative time zone. The shales in this zone are characterized by thin interbedded calcareous shale or silty limestone. Foerstian thalli generally appear as ovate or lobate black carbonaceous flakes marked by prominent cellular reticulation. They occur, singly or in masses, along bedding planes in light- to dark-gray shale or silty shale interbedded with black shale. Tetrads of trilete foerstian spores are commonly present in contact with or enclosed by the thalli, but isolated foerstian spores were not found in any of the macerated samples taken from the foerstian zone. Associated microfossils include hystrichosphaerids, a few dicrosporoid spores, and Tasmanites. Tasmanites, howerer, is generally not as abundantly represented as in the beds below and above this zone, nor is it intimately associated with the foerstian thalli.

Hystrichosphaerids are commonly found in the Huron member above the foerstian zone. Hystrichosphaeridium ohioensis and $H$. trispinosum become abundant in the uppermost beds of the Huron member or its equivalent. Dicrospora porcata and Cirratriradites sp. A are also represented in the uppermost part of the Huron member.

Discrosporoid spores and other land-plant spores first occur abundantly in the Chagrin shale, especially at localities 6 and 8. Dicrospora multifurcata, D. por$c a t a$, and $D$. amherstensis? are present throughout the shale, but are more abundantly represented, occurring

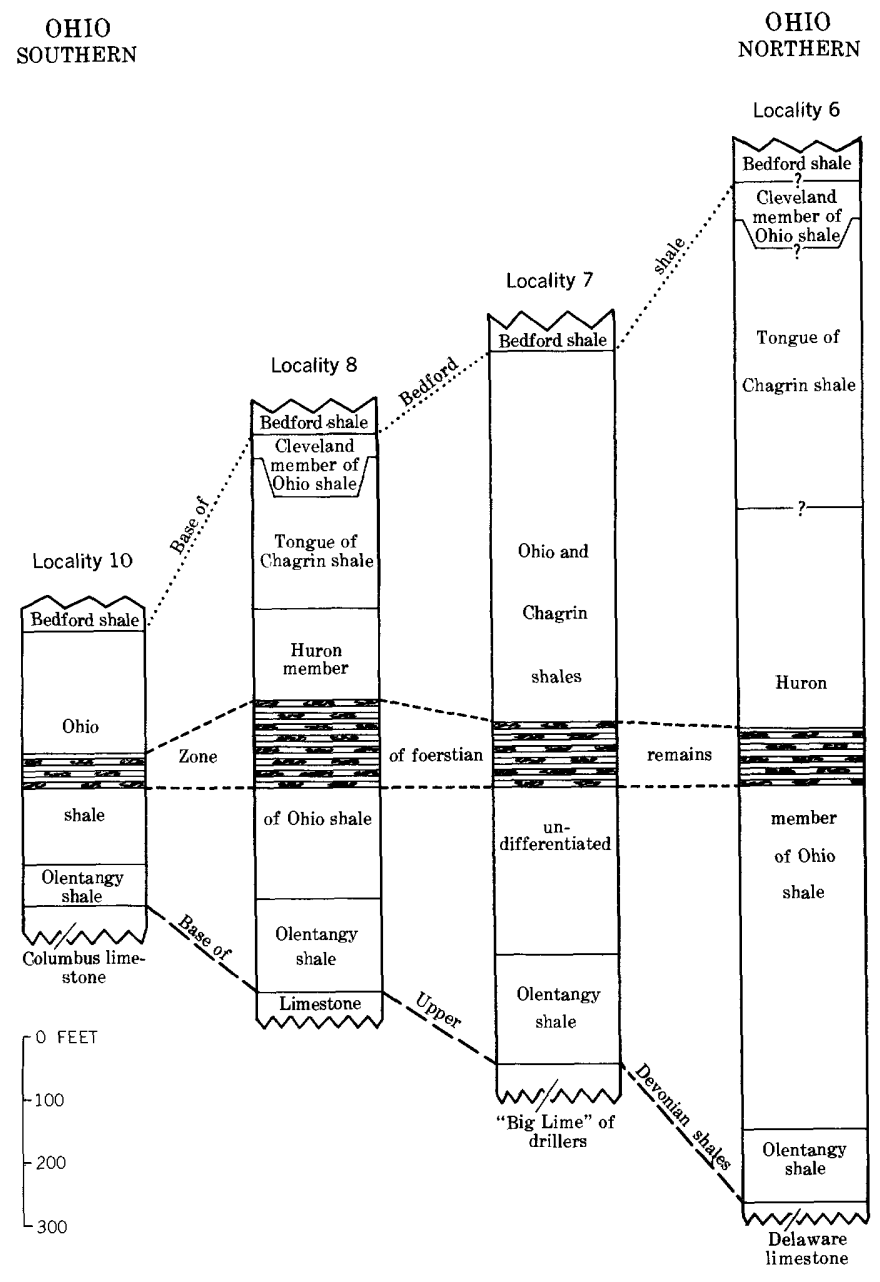

FigURE 3.-Diagrammatic columnar sections at four localities in ohio, showing the stratigraphic position of foerstian remains. Note thickening of Upper Devonian rocks toward northern ohio.

with $D$. multifurcata var. impensa, in the upper beds of the Chagrin shale. Spores of Endosporites chagrinensis are the most conspicuous and persistent of the smaller spores in lateral distribution (fig. 4). Cirratriradites sp. A is also present and spores of Radforthic radiate occur sporadically. Small spores that first occur infrequently in the upper beds of the Chagrin shale are those of: Calamospora, Grandispora, Reticulcutisporites crassus, and Canthospora cracens. A few rather poorly preserved megaspores and vascular fragments, sometimes abundant, were found in some of the samples of Chagrin shale. Disseminules of Tasmanites sinuosus are abundant in some beds of the Chagrin shale, but they do not occur in abundance in association with large numbers of land-plant spores. Hystrichosphaerids are present in samples containing abundant Tasmanites. At some places, they are abundant in samples containing land-plant spores, but generally they are scarce wherever land-plant spores are abundant. Hystrichosphaeridium trispinosum and Micrhy- 
stridium sp. A occur most abundantly in the lower beds of the Chagrin shale, but are present throughout the shale. Hystrichosphaeridium ohioensis and $H$. cf. $H$. longispinosum are also present throughout the shale.

Where the shale of the Cleveland member, the upper member of the Ohio shale, is dense and black (locs. 1,2 , and 8 ), it contains very poorly preserved spores but abundant well-preserved Tasmanites. In contrast, the Cleveland member at locality 6 contains abundant land-plant spores, hystrichosphaerids, and some Tasmanites. Endosporites chagrinensis occurs abundantly in the Cleveland member at locality 6 , whereas $E$. lacunosus occurs in the Cleveland member at locality 1. Although spores of E. lacunosus are very abundant in the upper 2 inches of the shale, which may actually represent the lowermost part of the Bedford shale (see comment under discussion of loc. 1), only one spore of this species was found in lower beds of the Cleveland member. The spores of these two species of Endosporites have not been observed to occur together. The known occurrences and intervals of greatest abundance of the two species are indicated on figure 4 . The upper limit of E. lacunosus is not indicated because of the lack of control samples in overlying beds at localities $1,2,3,8$, and 9 .

The following are present in the Cleveland member: Cirrutriradites sp. A, Reticulatisporites crassus, Canthospora cracens, Reticulatisporites? fimbriatus var. spathulatus, Radforthia radiata. Megaspores of Triletes catenulatus and spores of Dicrospora porcata, D. multifurcata, and D. multifurcata var. impensa are also present. Hystrichosphaeridium trispinosum and $H$. ohioensis are sometimes abundant and $H$. cf. $H$. longispinosum and Micrhystridium sp. A are some-

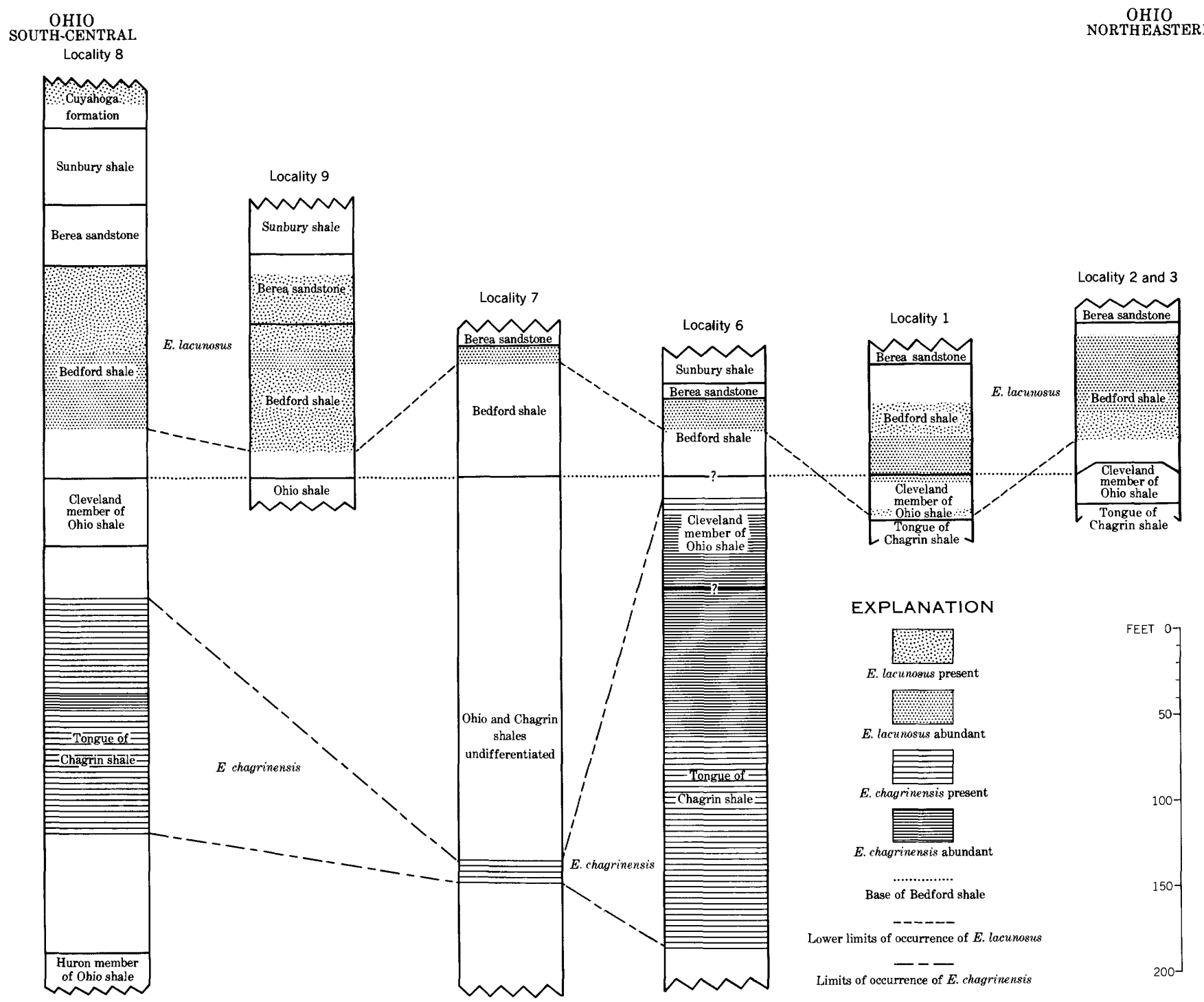

FIGURE 4.-Diagrammatic columnar section from seven localities showing the stratigraphic occurrence and relative abundance of spores of Endosporites lacunosus n. sp. and E. chagrinensis n. sp. 
times present in the Cleveland member. Tasmanites sinuosus disseminules are often abundant and well preserved in comparison to the land-plant spores in the dense black shale of the Cleveland member. A few very poorly preserved larger and thicker walled disseminules of Tasmanites are present in the upper 2 inches of the Cleveland member at locality 1.

Wells (1947) postulates that the Ohio shale was deposited below wave base in muddy brackish water, poorly aerated at depth, and that the plant and fish remains were drifted in by the streams of Cincinnatia. The types and distribution of land-plant microfossils found at the localities sampled during this investigation do not reveal any indication of a western or southwestern source area.

\section{LOWER MISSISSIPPIAN STRATA}

The microfossil assemblages of the lower part of the Bedford shale are strikingly different in aspect from older assemblages in that larger plant microfossils, such as megaspores, the larger spores of Dicrospora, and tracheid fragments, are very abundant, especially at localities 1,2 , and 3 , closest to the source area of the delta phases of the Bedford shale. At other localities only isolated specimens or fragments of the larger microfossils have been observed. The Bedford shale in northern Ohio also contains a greater abundance of plant microfossils than the underlying Cleveland member. Southward this contrast disappears. In general, however, the upper beds of the Bedford shale at all localities sampled contain abundant small spores.

Commonly the following are represented in the Bedford shale in northern Ohio: Triletes aries, T. auritulus, T. catenulatus, T. catenulatus var. marginatus, $T$. cervicornis, T. globulus, vascular fragments and fragments interpreted as sclerenchymatous "nests." The megaspores of $T$. catenulatus and T. globulus are usually very common. The sclerenchymatous "nests" are especially abundant in the upper part of the Bedford shale. Spores of Dicrospora, particularly the larger ones, are also present in the Bedford shale. The following species based on small spores are usually abundantly represented in the Bedford shale: Cirratriradites hystricosus, Endosporites lacunosus, E.? crassaspinosus, and Reticulatisporites? fimbriatus. Cirratriradites hystricosus is represented in the Bedford shale at every locality. Small spores of Endosporites lacunosus are the most abundant and consistently occurring spores in the Bedford shale (fig. 4). Very abundant isolated spores and sporangial masses of this species are present at localities 1, 2, and 3. This is further evidence that the Bedford shale in the Cleveland area was closer to land and the site of plant growth than the Bedford shale at any of the other localities. E.? pseudoradiatus is commonly represented in the Bedford shale at most localities and apparently restricted to this shale. Spores of the following species are present in the Bedford shale: Lycospora? sp. A, Cirratriradites sp. A, C. sp. B, Densosporites sp. A, $D$ ? sp. B, Reticulatisporites? fimbriatus var. spathulatus, $R$. crassus, Punctatisporites cf. P. nitidus, Cyrtospora clavigera, Canthospora patula, C. cracens, Convolutispora tuberosa, $C$. sp. A, Anapiculatisporites? retusus, and Radforthia radiata. Spores of Laevigatosporites and Calamospora are rare. Rare abraded large and rather thick walled Tasmanites disseminules are present in the Bedford shale in northern Ohio. Tasmanites sinuosus, Hystrichosphaeridium trispinosum, $H$. cf. $H$. longispinosum, and $H$. ohioensis are present in the Bedford shale at some localities south of the Cleveland area.

Plant fragments are generally not as abundant in the red as in the gray Bedford shale, but where spores or other plant materials occur in the red shale, the fragments are surrounded by gray reduction aureoles. This conforms with observations of Pepper, de Witt, Demarest (1954) that suggest sediments which made up the Bedford shale were originally derived from upland red soils which were reduced to gray muds only where deposited in a reducing environment (that is, deposited with an abundance of decaying plant material).

The content of the microfossil assemblages in the Berea sandstone is not as uniform from one locality to another as is that of the assemblages of the Bedford shale. Microfossils were found only at localities 5 and 9. The sandstone at locality 5 contains carbonaceous layers (pl. 2, fig. 1) and megaspores of Triletes auritulus, T. catenulatus, T. cervicornis, T. globulus (rare), T. aries (rare), T.? sp. B. and Dicrospora amherstensis. Many fragments of vascular tissue and sclerenchymatous "nests" occur with megaspores. Many isolated small spores and sporangial masses of Endosporites lacunosus characterize the sandstone at locality 5. Other small spores present are those of Lycospora? sp. A, Endosporites? crassaspinosus, Calamospora obtecta, Reticulatisporites crassus, Laevigatosporites, Cyrtospora clavigera, Canthospora cracens, and Anapiculatisporites? retusus. Species present in the Berea sandstone at locality 9 are: Endosporites lacunosus, $E$.? crassaspinosus, Dicrospora porcata, Reticulatisporites? fimbriatus, R. crassus, Verrucosisporites depressus, and Canthospora patula. A few disseminules of Tasmanites sinuosus, Hystrichosphaeridium ohioensis, and Micrhystridium sp. A are present in the sandstone at locality 9. Very few species are present in the Berea sandstone that are not also present in the Bedford shale. 
The distributional pattern and the similarity of the microfossil content of the Bedford shale and Berea sandstone agree well with Pepper, de Witt, and Demarest's (1954) interpretation of these sediments as a genetically related wedge of sediments representing a cycle of deposition during an oscillation of the land and sea between two periods of quiesence. The deltaic phases, at least, originated mainly from a northern source area.

The distribution of microfossils in the Sunbury shale, as shown on plate 23, may be somewhat misleading. It is likely that more species are present than have been noted during this study. Well-preserved and identifiable microfossils are rather rare, and finely divided organic matter tends to obscure the forms that are present in the maceration residues. Only the following have been identified from the Sunbury shale: Cirratriradites sp. A, Endosporites? crassaspinosus, Radforthia radiata, Densosporites? sp. B, Verrucosisporites depressus, Cyrtospora clavigera, Convolutispora tuberosa, $C$. sp. A, Anapiculatisporites? retusus. Neither Dicrospora nor hystrichosphaerids were noted in this formation. The black shale of the Sunbury probably represents the slow deposition of an organic mud in a shallow somewhat stagnant sea which had inundated the Bedford-Berea delta and the stream channels which had carried these sediments (Pepper, de Witt, and Demarest, 1954). Such a depositional environment accounts for the scarcity of all but the smallest of plant microfossils. Tasmanites, so abundant in Upper Devonian beds and supposedly having a similar depositional environment, is notably absent.

Microfossils of the lowermost shales of the Cuyahoga formation (locs. 6 and 8) are similar to those of the Sunbury shale, except for the absence of Verrucosisporites depressus and the recurrence of spores found in the Bedford shale and Berea sandstone, such as those of Endosporites lacunosus, Reticulatisporites crassus, and Canthospora cracens. Triletes catenulatus var. mixtus is also present. One specimen of Tasmanites sinuosus was found at locality 6 . Very few plant microfossils occur in the beds of the lower part of the Cuyahoga formation that contain marine fossils.

The assemblages in the upper part of the lower half of the Cuyahoga and Black Hand formations (undifferentiated) are characterized by abundant megaspores of Triletes catenulatus var. mixtus and $T$. variabilis. $T$. aries is sparsely represented. Small spores of Cyrtospora clavigera are very abundant. Also represented are Reticulatisporites crassus, R.? fimbriatus, Anapiculatisporites? retusus, and Densosporites sp. A.

The upper half of the Cuyahoga and Black Hand formations (undifferentiated), as well as the Logan formation, contains an abundance of plant microfossils.
The assemblages of the few samples taken from the upper part of the Cuyahoga and Black Hand formations (undifferentiated) are characterized by abundant small spores of Endosporites? crassaspinosus and $\mathbf{C} \mathbf{i r}$ ratriradites hystricosus, and by Granulatisporites logani. The occurrence of Granulatisporites logani is the oldest record of spores definitely referable to the genus Granulatisporites (in the sense of, Schopf, Wilson, and Bentall, 1944), although these spores are larger and bear stouter ornamentation than most spores previously referred to the genus. Also represented are Reticulatisporites? fimbriatus and Densosporites sp. A. Large spores of Triletes catenulatus var. marginatus?, $T$. catenulatus var. mixtus, and T. variabilis, particularly those of the latter two, dominate the megaspore assemblage.

Although the Cuyahoga and Black Hand formations (undifferentiated) were deposited in a marine environment, deltaic in part, Hyde (1953) inferred that some of the beds were deposited very close to shoreline. The presence of abundant megaspores in some of these beds would seem to support this inference.

The Logan formation was deposited under more uniform conditions than the Cuyahoga formation and the lower part of the Black Hand formation. Hyde (1953) notes that his Allensville member of the Logan formation (part of the Black Hand formation, this report) represents deposition from an eastern source after general shoaling of the region, and that, in contrast, his Vinton member (the Logan formation, this report) was deposited in much quieter deeper water. However, the samples investigated, probably from the Logan formation contain abundant megaspores which again indicates closeness to shoreline. The Logan formation is characterized by abundant spores of Punctatisporites? logani and by the rather robust megaspores of Triletes triquetrus. Also abundantly represented are Cirratriradites hystricosus, Endosporites? crassaspinosus, and Granulatisporites logani. Less abundantly represented are Triletes variabilis, Densosporites sp. A, Punctatisporites cf. P. nitidus Hoffmeister, Staplin, and Malloy, and some spores similar to others of Punctatisporites described by these authors from Upper Mississippian strata of Illinois and Kentucky. The assemblages from the Logan at locality 7 contain spores similar both to those of earliest Mississippian age and to those of Late Mississippian age, but they nevertheless appear to be distinguishable.

\section{GENERAL NATURE OF FLORAS}

REVIEW OF MEGAFOSSIL EVIDFNCE

The information as to the composition of Upper Devonian and Lower Mississippian floras in North 
America has been based largely on evidence from megascopic fossils; that is, fronds, stems, and larger plant parts. White (1909) believed that the Upper Devonian flora, characterized by Archaeopteris, showed little evidence of climatic contrast with that of the Middle Devonian and developed or evolved mainly in eastern North America or in the Arctic region. According to Arnold (1939) the Devonian lycopods are too poorly preserved to permit exact comparison with the Mississippian forms from the Pocono formation, although these appear to bear greater resemblance to one another than the corresponding ferns or pteridosperms(?). Kräusel and Weyland (1941) have more recently reviewed the composition of Upper Devonian floras in North America.

The transitional Devonian-Mississippian petrifaction flora, described by Cross and Hoskins (1952) and Hoskins and Cross (1952), from the upper part of the New Albany shale in central Kentucky and southern Indiana, includes an unique and diverse assemblage of plants of fairly restricted stratigraphic range. Prominent constituents of this flora (Cross and Hoskins, 1951) are the Calamopityeae, Pityeae, and some genera of uncertain affiliation. Cordaitaleans, filicaleans, calamiteans, and lycopsids are present. Possibly other types are sparsely represented. This flora is similar to neither Devonian nor Mississippian floras as generally recognized. The exact age relation of the Falling Run member of the Sanderson formation of Campbell (1946), in which these petrifactions are found, to the Bedford shale and basal part of the Pocono formation is not known with certainty.

The Lower Mississippian flora contrasts sharply with that of the Upper Devonian in most regions. The flora of the Catskill formation of Middle and Late Devonian age is characterized by Archaeopteris, whereas the lower part of the Pocono formation of Mississippian age is characterized by a flora dominated by Adiantites and the upper part of the Pocono formation and the Price sandstone are characterized by an abundance of Triphyllopteris (Read, 1955). Amold (1948a) notes the absence of sigillarians and cordaites and rare fragmentary occurrences of calamiteans. It is possible that this contrast between Upper Devonian and Lower Mississippian floras may be due, in part, to changes in climate and sedimentation that attended the postDevonian orogeny which produced the eastern uplands and bordering coastal plains (White, 1934).

Read (1955) states that the meager available evidence suggests that the post-Pocono Mississippian floras may be distinct from those of the Pocono and Price formation.

\section{INTERPRETATION BASED ON MICROFOSSILS}

The present study confirms Dawson's (1888) early obeservations regarding the variety of species represented by microfossils in the Bedford shale. However, a great variety of species represented by microfossils, in contrast to Dawson's observations, is also present in the Ohio and Chagrin shales. The results of the present study seem to support Dawson's opinion, based on evidence shown by plant megafossils, that there exists in strata in Ohio a transitional DevonianCarboniferous flora.

The variety and abundance of plant microfossils, especially spores, in rocks of Late Devonian and Early Mississippian age indicate the diversity of the then existing floras. In the sequence examined in Ohio, no great variety appears below the Chagrin shale or its age equivalents (pl. 23). However, studies in other areas (for example, in the Russian platform [Naumova, 1953]) have revealed an extensive variety of spore types occurring throughout rocks of Late Devonian age.

Unfortunately, the affinities of only a few of the spores of Late Devonian age from Ohio can be suggested. The presence of herbaceous and arborescent lycopods is indicated by spores of Cirratriradites, Triletes, and possibly Endosporites; sphenopsids are represented by spores of Calamospora and possibly Reticulatisporites. The alliance of Dicrospora, Punctatisporites, Canthospora, and other types not described in the present study, is unknown. However, Punctatisporites, in part, may be allied with the Filicales. Occasionally vascular tissue and minute stems are the only microfossils, except for Tasmanites, found in maceration residues of Upper Devonian dark shales. However, the vascular fragments of Callixylon, known from Upper Devonian megafossils, were not recognized in Upper Devonian maceration residues.

An extremely varied plant microfossil assemblage appears in the Bedford shale of Early Mississippian age (pl. 23). The present writer believes that this assemblage does not necessarily signify an evolutionary spurt among plants, but rather is indicative of nearness to shoreline and of stronger stream velocities involved in deposition of the sediments that formed the Bedford shale. Indeed, Pepper, de Witt, and Demarest $(1954$, p. 99) postulate heavy precipitation (with consequent abundance of vegetation) in the highlands of northeastern Canada, the source area of most of the Lower Mississippian sediments of the Bedford and the Berea. Some of the variation between Upper Devonian and Lower Mississippian plant microfossil assemblages may be the result of the shift from a dominantly 
eastern source area, possibly maintaining a slightly different plant population, to a dominantly northern source area. However, some of the small spores of the Bedford shale are very different from any observed in underlying beds. It seems as though gradual diversification of plant communities must account for some of the distinctive spore types first occurring in the Bedford shale. The large spores or megaspores are not as uniformly distributed as are the small spores. Although no megaspores of Triletes are present in beds older than those of the Cuyahoga and Black Hand formations (undiffereniated) at locality 7, megaspores are known from older beds at other localities. Megaspores, because of their large size, are more restricted to sites of deposition close to shoreline than are the smaller spores. The absence of Triletes megaspores in older beds at locality 7 cannot be due to the nonexistence of heterosporous plants, but rather due to sedimentary processes unfavorable to their deposition or, a remote possibility, conditions unfavorable to their preservation.

The Lower Mississippian flora consists of many types of lycopods (represented by spores of Triletes, Lycospora?, Cirratriradites, and possibly Endosporites), sphenopsids (represented by spores of Calamospora and possibly Reticulatisporites), and ferns (represented by spores of Punctatisporites, in part, and possibly by Granulatisporites, Verrucosisporites, and Anapiculatisporites?). A number of other types of spores are present, unknown as to affinity, that merely suggest a varied flora. Vascular and cuticular fragments are usually abundant in the Bedford shale, Berea sandstone, and younger beds. In general the spore assemblages found in the Bedford shale and Berea sandstone are different from those found in the Cuyahoga and Black Hand formations (undifferentiated), which in turn are different from those found in the Logan formation. Whether or not these differences are caused by evolutionary changes, ecologic changes in plant communities, or by a combination of these factors, which seems most probable, cannot be stated. Some of the variation may be caused by the change from a dominantly northern source area during deposition of the Bedford and Berea formations to a dominantly eastern or southeastern source area, for at least southern and central Ohio, during deposition of the Cuyahoga, Black Hand, and Logan formations.

A comparison of the spore assemblages described from the Upper Devonian by the present writer with those of comparable age described from other parts of the world reveals many similarities in spore types. For example, dicrosporoid spores are reported from Middle and Upper Devonian rocks in many areas and Calamo- spora spores are reported from Devonian rocks of other areas (Naumova, 1953; Hoffmeister, Staplin, and Malloy, 1955a). In spite of general similarities, comparison of the few described forms found in the Upper Devonian of Ohio with, for instance, those from the Upper Devonian of Russia reveals none that appear to be conspecific. Thus, uniformity, in the strictest sense, of Upper Devonian floras is not indicated. Because of the lack of published information, comparison of the Lower Mississippian spore forms found in Ohio rocks with those from other areas is not yet possible.

\section{SUMMARY}

Abundant plant or sporelike microfossils are present in Upper Devonian rocks in Ohio. Those derived from land plants are associated with the silty gray Chagrin shale which was derived mainly by sedimentation from an eastern source area. Spores of land plants are notably abundant at locality 6 in northeastern Ohio and at locality 8 in south-central Ohio. They are present at locality 7 even though the Chagrin shale at this locality is not lithologically definable. However, at locality 10 , Upper Devonian rocks contain very few microfossils of land-plant derivation (fig. 1).

Tasmanites is evidently not related to the terrestrial vegetation but its affinity is still a question. It is characteristic of the black thin-bedded euxinic marine facies of the Ohio shale, but it seems to be absent from the Sunbury shale of similar lithology. Disseminules of Tasmanites also are lacking or sparsely represented in at least a part of the Chagrin shale, even though the gray silty facies is not characteristically differentiated, as at locality 10. They are not present in deposits of direct continental derivation, such as the channel sandstones of the Berea. Tasmanites seems always to be associated with marine or brackish facies within the Chagrin shale, Bedford shale, or Berea sandstone. Spores of land plants are lacking or poorly represented in these occurrences. Probably Tasmanites represents a group of planktonic or nektonic organisms that flourished in the epilimnion in marine or brackish water.

Common occurrences of the hystrichosphaerids were first noted in the foerstian zone, although rare specimens were found below this zone. They may occur with an abundance of Tasmanites but are most commonly associated with land-plant remains, although not with the most abundant occurrences of land-plant remains. Possibly the hystrichs represent brackishwater planktonic organisms.

The foerstians evidently are characteristic of marine deposits and are unusual in being restricted within a zone in the black euxinic facies of the Ohio shale. The significance of their narrowly restricted stratigraphic 
distribution, in a zone in constant relative position to established conodont zones, is at present unknown. The great lateral extent of foerstian remains and their rare association with land-plant spores or abundant hystrichosphaerids suggest that the foerstians floated sargassumlike in a pelagic, rather than littoral, environment. Overturn of poorly aerated bottom water, possibly during storm periods, could account for the introduction of extensive masses of well-preserved plant material into the bottom environment.

The greatest concentration of land-plant remains in lowermost Mississippian rocks in northern Ohio indicates a northern source area for these sediments. Moreover, a northern source area has already been postulated on the basis of geologic evidence (Pepper, de Witt, and Demarest, 1954). Near-shore conditions are also indicated by abundant plant remains in some beds of the Cuyahoga, Black Hand, and Logan formations. In contrast to the Upper Devonian occurrences, hystrichosphaerids and Tasmanites, with few exceptions, seem to be absent or much less common in beds of Early Mississippian age.

Although many problems, especially those relating to environmental or ecological interpretation, remain unsolved, a wealth of potentially valuable paleontologic data can be found in these rocks.

\section{SYSTEMATIC DESCRIPTIONS}

Plant Kingdom
Subkingdom EMBRYOPHYTA
Division TRACHEOPHYTA
Subdivision LYCOPSIDA
Class LYCOPODINEAE
Order and Family UNCERTAIN

Genus TRILETES (Bennie and Kidston, 1886) ex Zerndt, $1930^{4}$

Plates $3,4,5,6$; plate 7 , figures $1($ ?), $1 \mathrm{a}($ ?), $1 \mathrm{~b}($ ?), 2-7; plates 8 , 9; plate 17 , figures $10-12$; plate 19 , figures 9 , 9a, 10, 11; and figure 5

Type species.-Triletes glabratus Zerndt, 1930 (=Triletes I Bennie and Kidston, 1886).

Description.-Megaspores radially symmetrical, proximal sides marked by a prominent triradiate suture, often with arcuate ridges or a flange connecting the ends of the rays. Spore coat smooth or variously ornamented; ornamentation generally more developed distally. Spores generally large, some exceeding $3 \mathrm{~mm}$. Megaspore coats adapted to protection and dissemination of megagametophytes and other aspects of reproduction that characterize ancient free-sporing lycopsids.

Discussion.-The author prefers to use the preceding interpretation of Triletes that is adhered to by most

\footnotetext{
4 This citation was suggested to the author by J. M. Schopf, who now believes that it accurately reflects the true nomenclatural status of Triletes when that name is applied to a taxon of generic rank.
}

of those who have studied fossil megaspores, rather than the interpretation recently given by Potonié and Kremp (1954). They use the name Triletes to designate a division of their sporomorphic system and include in it all trilete-type isospores, microspores, and megaspores that lack auricles, equatorial rims, flanges, or bladders. This does not conform with any natural grouping of plants and does not seem as suitable as the usage followed by Seward, Bartlett, Zerndt, Harris, Schopf, Cross, Arnold, Dijkstra, Kalibova, Chaloner, Surange, Srivastava, Singh, and others since Bennie and Kidston (1886).

Sections of Triletes.--Schopf (1938) proposed that certain groups of species be allocated within four sections based on comparative spore morphology and other evidence that suggested lines of intrageneric alliance or affinity. Kidston's informal groups Apiculati and Zonales were discontinued because they are expressive of arbitrary distinctions that transgress natural relationships. They are based on characters that have developed independently on several occasions in groups of diverse relationship. Schopf, Wilson, and Bentall (1944) did not make a sectional assignment of all species of Triletes, though they did note the sectional affiliation for a few additional species.

Dijkstra (1946) included the species of Schopf's section Auriculati under the section Aphanozonati and reinstated the Zonales of Bennie and Kidston as a section. He continued the use of the sections Lagenicula and Triangulati.

Chaloner (1953a) discussed the section Aphanozonati and described a group of originally saucer-shaped spores (Triletes mamillarius and T. glabratus) originating from a Mazocarpon type of sporangium, hence of Sigillarian affinity. He split the section Aphanozonati into the Aphanozonati, in the strict sense, and Mazospora, new section. Although his approach to the problem of determining original spore shape is indeed a contribution, his new section Mazospora does not seem to be taxonomically valid. Chaloner based the new section on the two species for which the section Aphanozonati was originally constructed. Therefore, A phanozonati, in the strict sense, is equivalent to Mazospora and holds priority over the latter. It would be plausible to describe another section for those spores which are not concavoconvex or planoconvex and which are now included in the Aphanozonati in its more general usage.

The following paragraphs give a résumé of the four sections of Triletes as given by Schopf (1938, p. 24) who describes the section Aphanozonati as:

*** spores large ; round or oval. Zonal appendages lacking; arcuate ridges usually present. Trilete structures moderately proportioned, lacking strong apical prominence, and usually 
occupying about half of the area of the proximal "hemisphere" (planimetric measurement). Spore coat generally thick. Surface ornamentation variable, sometimes extremely apiculate.

Spores of the section Auriculati are of medium size, axially shortened, with a generally subtriangular or trilobate form due to the expansion of the spore coat opposite the trilete radii. Flange may be moderately developed in the interradial areas. The rays are long, extending from apex to equator. Generally the spore coat is nearly opaque and relatively thick.

Schopf $(1938$, p. 31,32$)$ describes spores of the section Triangulati as:

\footnotetext{
*** of medium size or somewhat smalker. Spore body usu. ally round to oval; zonal appendages, when present, sometimes radially extended lending a triangular appearance. Such zonal appendages usually are somewhat membranous, thinner than the spore coat proper. Arcuate marking or equivalent zonal structures commonly present near the true equator of the spore body. Trilete rays generally long in proportion to body size. Surface smooth or variously ornamented by reticulation.
}

Selaginellites is known to have similar megaspores, and it was suggested that the Triangulati are allied with some of the herbaceous heterosporous lycopods. Chaloner (1954a) confirmed the general equivalence of the Triangulati and the herbaceous lycopods (Selaginellites). More recently Hoskins and Abbott (1956) described a bisporangiate lycopsid strobilus containing megaspores of Triletes triangulatus-type and microspores similar to Cirratriradites annulatus. Guenne] (1954) describes the morphology of spores of Triletes triangulatus in detail.

Lagenicula was originally proposed as a group by Bennie and Kidston $(1886$, p. 114, 115) to inchude megaspores of oval to circular outline (when laterally compressed) provided with a necklike projection which eventually splits into three subtriangular segments. Schopf (1938, p. 27, 28), emending this description, described these spores as being characterized by a general change in the shape of the spore reflecting axial extension and involving the apical segments whereby the elongated and upraised apical flaps are more or less distinctly set off from the lower part of the three contact faces.

Schopf (1938) states there is no reason to doubt that species of Lagenicula were produced by heterosporous lycopods. Chaloner (1954b) notes that at least three members of the Lagenicula section are believed to have been borne by Lepidodendron and that there is no reliable report of their having been borne by a member of any other genus.

Sectional affinity of Upper Devonian and Lower Mississippian spores of Triletes.-It is important to note that the sections of Triletes have been based on spores of Mississippian and Pennsylvanian age (Early and Late Carboniferous of Europe and Asia), generally of a younger age and that they consequently represent plants different in character from those represented by the spores described in this paper. It can be expected that these Upper Devonian and Lower Mississippian plants, as a whole, may show characteristics of several of the sections of Triletes and that any one species may not correspond precisely with any one of the sections as they are now defined.

Spores of T. auritulus n. sp. can undoubtedly be referred to the section Lagenicula. These spores, however, show a hyperlageniculate development of the apical prominence in relation to general body size.

The oldest spores described as Lagenicula I by Bennie and Kidston were found in the Calciferous Sandstone a few feet above the top of the Upper Old Red Sandstone in Scotland. These spores show a more typical lageniculate development than do those lageniculate spores described in this paper, except possibly those found in the Logan formation of Ohio.

If distal spore coat ornamentation is considered as a genetically controlled feature, then those spores showing similarity in ornamentation or variations thereof may be genetically related. Species described in this paper as Triletes catenulatus n. sp., T. cervicornis $\mathrm{n}$. sp. T. variabilis n. sp., and $T$. triquetrus n. sp. all possess the catenulate type of distal spore coat ornamentation or a variation of it and are probably related botanically.

Spores of $T$. catenulatus, T. catenulatus var. marginatus, T. cervicornis, and T. variabilis possess apical prominences that are quite high relative to spore body size. These prominences correspond in configuration to those shown especially well on plate 5 , figure 5 and plate 6, figure 2. The lips decrease in height gradually from the proximal pole to about midway along the ray, there decreasing rather abruptly to a low lip which extends slightly beyond the margin of the body (pl. 5, fig. 5). The prominence of $T$. triquetrus is of the same shape but somewhat reduced in size. These related spores possess apical prominences that are not basally constricted like those commonly shown by spores typical of Lagenicula. Furthermore, the spore body varies from distinctly oblate to spheroidal. The well-developed flange of T. catenulatus var. marginatus is similar to that of $T$. triangulatus. Therefore, it seems that spores of the above group have features in common with spores of the Lagenicula, Aphanozonati, and Triangulati sections. However, the spores of the catenulate type from younger beds, $T$. variabilis and $T$. catenulatus var. mixtus, show a tendency toward the development of a constricted lageniculate apical prominence. From this, one may infer that the catenulate group preceded typical differentiation of the three sec- 
tions of Triletes. They are assigned to the section Lagenicula because their alliance and evolutionary tendencies seem most definitely alined in that direction.

Spores of T. globulus n. sp. and T. aries n. sp. also pose a problem. Both spores possess apical prominences which are unlike the typical lageniculate prominence. These spores appear to be related to those of dominantly Namurian species, usually classed within Lagenicula, that have a rotund body contour, thick spore coat, and prominent trilete structures. The apical prominence usually predisposes the megaspores of these forms to lateral compression. This related group includes $T$. subtilinodulatus (Nowak and Zerndt) S. W. \& B., ${ }^{5}$ T. agninus (Zerndt) S. W. \& B., T. simplex (Zerndt) S. W. \& B., T. splendidus (Zerndt) S. W. \& B., and T. indianensis Chaloner (included in A phanozonati by Chaloner). These spores stand out in sharp contrast with the typically bottle-shaped thinner walled spores that seem more naturally allied within Lagenicula. Apparently $T$. agninus, T. aries, and the others are principally restricted to the Mississippian and Lower Pennsylvanian rocks of North America and Europe (Dijkstra, 1952). Chaloner (1954b) reports $T$. indianensis and Schemel (1950) reports $T$. agninus from the Mississippian rocks of this country. Spores of T. globulus and T. aries are questionably referred to the above group and, therefore, questionably to the section Lagenicula.

The spores described as Triletes sp. A and those shown on plate 19 figures 9 and 11 may be related to the Aphanozonati in a broad sense. There is a possibility of origin from Sigillarian ancestors but this is speculative. Those of Triletes? sp. B are not assigned to a section as it is not definitely known whether they represent $T$ riletes or Dicrospora.

Occurrence.-Spores of Triletes, in particular lageniculate spores, are reported from beds as old as Upper Tournaisian in Europe, Asia, and the U.S.S.R. (Potonié and Kremp, 1954, p. 183). It is not known whether the lageniculate spores described by Bennie and Kidston (1886) from the Califerous Sandstone of Scotland are equivalent in age or younger than those described from the Bedford shale of Ohio. Spores of the genus Triletes form a striking part of the plant microfossil assemblage of the Lower Mississippian because of their large size and number of distinctive species.

The oldest megaspore referable to Triletes was found at locality 6 in the Chagrin shale about 375 feet above the foerstian zone. This spore has a catenulate type of ornamentation but is not referable to any species

\footnotetext{
5 S. W. \& B. ; commonly used abbreviation for Schopf, Wilson, and Bentall, 1944.
}

described here. The upper part of the Ohio shale or Chagrin shale at this locality has yielded several Triletes megaspores, but their preservation is quite poor. The genus is also represented in the upper part of the Chagrin shale at locality 8. No megaspores referable to Triletes were found below the Cuyahoga and Black Hand formations (undifferentiated) at locality 7 ; none were found in the Chillicothe core, locality 10 .

\section{Section IAGENICULA (Bennie and Kidston) Schopf, 1938} Triletes auritulus n. sp.

Plate 3, figures 1, 1a, 2, 2a, 3, 3a, 3b, 4, 5, 6 ; plate 4 , figures $1,1 a, 2$

Diagnosis.-Megaspores large, usually compressed laterally, prolate circular to prolate in outline, 1.1-2.29 $\mathrm{mm}$ long including apical extension (13 specimens measured). Spore body, excluding lips and ornament, prolate to suboblate in outline, ranging from $550 \mu$ to $1570 \mu$ in length. Internal spore cavity probably subspherical in original form.

Trilete structures highly developed (pl. 3, figs. 1-4) ; lips unusually prominent, ranging from about $260 \mu$ to $935 \mu$ in height and basally constricted (pl. 3, fig. 2a). Lip height (from base of lip, not from arcuate ridge) at apex ranges from 20 to 60 percent of total axial length. Trilete rays range from $260 \mu$ to $630 \mu$ long. Auricles (flaplike extensions of lips at ends of rays) conspicuous (pl. 3, figs. 1, 2a, 3, 4, 6; pl. 4, figs. 1, 2), platelike in form, commonly adding $40-55$ percent to ray length and range from $140 \mu$ to $300 \mu$ in height. Arcuate ridges thin but persistent, touching outer extremities of each auricle opposite the rays and arching moderately around contact areas.

Contact areas irregularly pitted, appearing striate to rugose with grain radiating from apex (pl. 3, fig. 2a), and occasionally bearing, as do basal parts of lips, acuminate spines about $10 \mu$ long. Distal surfaces rough, with sparsely scattered acuminate spines extending $10 \mu-60 \mu$ in length from somewhat expanded bases (pl. 3, figs. 1a, 3a).

Spore coat $20 \mu-25 \mu$ thick adjacent to trilete structures, as much as $45 \mu$ thick on distal suface of largest spore measured. Spore coat deep-reddish-brown by transmitted light; in highly oxidized specimens, yellowish brown; spore coat black to light brown by reflected light.

Holotype.-Plate 3, figures 1, 1a, from the Bedford shale, loc. 1 , maceration $40 \mathrm{C}$, slide 1 , collection 4-11-1-52.

Discussion.-The apical elaboration of spores shown by figures 2,3 , and 4 on plate 3 , is considered typical; 
that of the specimen shown on plate 3 , figure 6 is less prominent in proportion to body size than was observed on any other specimen. These apical prominences or lips are often found isolated, broken away from the spore body, and are up to $1,200 \mu$ in height. The maximum size given in the diagnosis, based on unbroken spores, may be considered conservative for spores of the species.

Although spores of $T$. auritulus have ears, it is apparent that these are a different kind of structural modification than that shown by spores included in the Auriculati section of Triletes. The ears of the auriculate spores appear to be on the equatorial line of arcuate development and tangentially expanded, whereas the auricles of spores of $T$. auritulus appear as a type of labial elaboration at the end of the ray and above the level of the arcuate ridge.

Of previously described species within the section Lagenicula, spores of $T$. auritulus seem most closely comparable to spores of $T$. angulatus (Zerndt) S. W. \& B. (See Dijkstra, 1946.) The former are slightly larger, more prolate, possess a more spatulate apex and generally shorter rays. The spore coat bears acuminate spines whereas that of spores of $T$. angulatus bears either short blunt appendages or is more or less smooth. The greatest distinction between the two is the form of the protuberances at the radial extremities. Those of $T$. angulatus were probably originally hollow and consist of an enlargement of the contact face in a vertical plane and of the arcuate ridge which evidently is about $48 \mu-177 \mu$ high and $8 \mu-48 \mu$ wide. The auricles of spores of $T$. auritulus are flaplike extensions, lips, of the contact faces at the ends of the trilete rays, separate from the main apical prominence. These extensions involve no concomitant modification of the arcuate ridge which, although weakly developed, connects the outer edges of the auricles.

With the exception of the one clavate spine shown by figure $3 b$ on plate 3 , the configuration and frequency of spines seems comparable to that shown on megaspores of Lepidostrobus braidwoodensis Arnold (1938, fig. 7, p. 711). The spines of these megaspores, however, are smaller than those of Triletes auritulus and the apical part of the Braidwood spores is a subordinate part with no suggestion of auricles.

The apical prominence of spores of $T$. auritulus may often show a hyperlageniculate development. On one spore the lips are $200 \mu$ longer axially and $300 \mu$ broader (perpendicular to the axis) than the spore body. However, in general form, spores of $T$. auritulus seem comparable to typically bottle-shaped spinose spores such as those of $T$. crassiaculeatus and $T$. horridus (both, in the sense of Dijkstra, 1946). The spores of 593123 0-62-6 -4 these two species types have been found in cones of Lepidostrobus (Chaloner, 1953b) of the arborescent lycopods.

Occurrence.-Spores of Triletes auritulus are present in the Bedford shale at localities 1, 2, and 3. Fragments were found in the Bedford shale at locality 9 . The most abundant occurrences noted were in the uppermost part of the Bedford shale at locality 3 and in the Berea sandstone at locality 5 (pl. 23).

Triletes catenulatus n. sp.

Plate 5, figures 4, 5(?), 6(?); plate 6, figures $1(?), 1 a(?)$, 2, 2a, 3, 3a, 3b

Diagnosis.-Megaspores of medium size, having no preferred compressional form; length overall (including apical prominence) of lateral compressions ranges from $425 \mu$ to $740 \mu$; diameter of proximodistal compressions ranges from $450 \mu$ to $620 \mu$. Spore body circular to oval in lateral outline, tending to subtriangular in proximodistal compressions (pl. 6, fig. 3) ; uncompressed spore body probably somewhat oblate to spherical.

Trilete structures highly developed, distorted when vertically compressed. Apical prominence of a subdued lageniculate type, shows no tendency to basal constriction (pl. 6, fig. 2) ; usually more than $200 \mu$ high, as much as $285 \mu$ high. Trilete rays range from $180 \mu$ to $270 \mu$ in length, often equaling height of apical prominence; on any 1 specimen, 1 ray appears shorter than the other 2 . In proximodistal compressions rays generally not extending to margin; in lateral compressions, especially partly denuded ones, rays projecting away from body in manner shown by figure 5 on plate 5 . Contact areas equaling about three-fifths or more of proximal surface, defined distally by edge of distal ornamentation which usually obscures a low arcuate ridge (pl. 6, fig. 2a).

Lips and contact areas generally smooth to granular; distal surface bearing numerous acuminate spines, $10 \mu-40 \mu$ long and occasionally developed as a flange extending $70 \mu$ at arcuate ridge. Spines thin basally, $5 \mu-12 \mu$ in diameter, expanding outward to $6 \mu-20 \mu$ in diameter; bulbous expansion bearing one or more acuminate tips, generally about $5 \mu$ in diameter and $10 \mu$ in height (pl. 6, figs. 2a, 3b). Spines connected, one to another, by spanlike extensions of bulbous medial part above spore coat in discontinuous reticulate pattern appearing chainlike when viewed down axis of spines (pl. 6, figs. 2, 3). Meshes $10 \mu-50 \mu$ in diameter when reticulate network is characteristically developed. Ornamentation rather easily torn from spore coat.

Spore coat $12 \mu-23 \mu$ thick, orange to reddish brown by transmitted light. 
Above diagnosis based on measurements of 21 typical specimens; varietal forms of this species described following discussion of typical forms of $T$. catenulatus (that is, T. catenulatus var. catenulatus).

Holotype.-Plate 6, figures $3,3 \mathrm{a}, 3 \mathrm{~b}$ from the Bedford shale, locality 2 , maceration 161 , slide 25 , collection 8-12-6-53.

Discussion.-Plate 6, figure 2, shows an example of 1 spore which has been split into 3 symmetrical and identical parts or valves, a feature which has been noted by Chaloner (1954b) as characteristic of Triletes angulatus. Specimens of other species of this study, including $T$. cauritulus, also show this characteristic splitting.

The ornamentation of the broken specimen shown by figure 4 , plate 5 , is of the typical catenulate type but somewhat sparsely developed. Those specimens shown by figures 5,6 , and 7 on plate 5 , are examples of rugose to smooth-coated spores bearing a subdued lageniculate apex that are quite commonly found associated with $T$. catenulatus spores. Many partly denuded spores of $T$. catenulatus show the same morphologic features and a smooth to rugose coat. In the author's opinion those spores shown by figures 5,6 , and 7 on plate 5 , are nothing more than completely denuded spores of $T$. catenulatus or one of its variants. Spores like those of figures 5, 6, and 7 are also found associated with $T$. catenulatus var. mixtus and T. vamabitis in maceration 364 .

The specimen shown by figures 1 and la, on plate 6 bears a resemblance to those of $T$. catenulatus in size, shape, and in the development of a reticulate network of spines. However, the spore is regarded as an extreme example of spores that represent a different species. These spores typically possess a discontinuous network of spines which are fused throughout most of their length and branch distally into frilled tips (pl. 6, fig. 1a). In any event these forms probably are closely related to $T$. cotenulatus.

No previously described species of Triletes are known to possess this catenulate type of spore ornamentation.

Occurrence.-Typical spores of this species ( $T$. catenulatus var. catenulatus) are common in the Bedford shale, especially in the lower part, at localities 1 , 2 , and 9 ; they are present in the Cleveland member of the Ohio shale at locality 6 , in the Bedford shale at locality 8 , and in the Berea sandstone at locality 5 (pl. 23).

Triletes catenulatus var. marginatus $n$. var.

Plate 5, figures 7 (?), 8, 8a ; plate 6 , figures $4,4 a, 5$

Diagnosis.-Megaspores of medium size, usually vertically compressed; overall length (including apical structures) of lateral compressions ranges from $440 \mu$ to $515 \mu$; diameter of spore body (excluding flange) in proximodistal compressions ranges from $300 \mu$ to $500 \mu$, somewhat less than for spores typical of the species (23 specimens measured). Effective diameter of spores increased $60 \mu-200_{\mu}$ by encircling flange.

Spore body moderately subtriangular in proximodistal compressions (pl. 6, fig. 4a) ; shape accentuated by extension of trilete rays onto flange and occurrence of maximum development of flange at ray extremities. Uncompressed spore body probably more oblate than that of spores typical of species.

Trilete structures highly developed, distorted when vertically compressed (pl. 6, fig. 4), having same configuration as spores typical of species. Apical prominence $120 \mu-235 \mu$ high. Suture extends almost to spore body margin; straight trilete rays extend to flange margin and appear as projecting points on partly denuded specimens. Base of rays or lips about $10 \mu$ wide. Contact areas occupy proximal hemisphere completely, larger relative to body size than is typical of species. Arcuate ridge commonly present at base of flange.

Lips and contact areas generally smooth to granulose, occassionally possessing ornamentation similar to that on distal surface but reduced in size. Distal ornamentation catenulate; adjacent bulbous-based spinules connected by a span above spore coat and presenting a reticulate appearance. Spine bases about $5 \mu$ high, as much as $10 \mu$ in diameter; spines as much as $10 \mu$ in length distally and as much as $38 \mu$ in length near flange, in general shorter than those on spores typical of species. Spines may be in scattered groups on distal surface (pl. 5, fig. 8) or so scarce as to be barely noticeable. Some specimens, probably abraded, have smooth to rugose distal coat.

Thin serrate flange ranges from $34 \mu$ to $100 \mu$ in width, widest at ends of rays (pl. 6, figs. ta, 5), is spinose throughout its width (pl. 5, fig. 8a), and originates from the fusion and prolongation of distal ornamentation. Spores typical of T. catemulatus, in contrast, sometimes possess a ragged, coarser flange (pl. 6, fig. $3 \mathrm{a})$; that is, a row of enlarged catenulate spines.

Spore coat $9 \mu-20 \mu$ thick, thickest distally and adjacent to ends of rays, generally $12 \mu-14 \mu$ thick along margin of contact area opposite a trilete ray. Spore coat orange brown by transmitted light, flange generally yellow.

Holotype--Plate 5, figures 8, 8a, from the Bedford shale, locality 1 , maceration $40 \mathrm{~A}$, slide 13 , collection 4-11-1-52.

Discussion.-Spores of this variety are generally smaller and possess a better developed flange, larger contact area, and shorter spines than those spores typi- 
cal of $T$. catenulatus. The equatorial flange and oblate body form have predisposed most specimens to proximodistal compression in spite of the high apical prominence.

Spores of $T$. catenulatus var. marginatus are most closely comparable to those of $T$. triangulatus Zemilt (in the sense of Schopf, 1938) of the section Triangulati. Chaloner (1954a) described T. triangulatus-type megaspores from Selaginellites suissei. This description further confirmed Schopf's suggestion of the general equivalence of the Triangulati and the herbaceous lycopods.

Spores of this variety of Triletes catenulatus, as opposed to spores of $T$. triangulatus, are generally slightly smaller, possess a less expanded flange, and the spore body shows a more pronounced subtriangular shape in the transverse plane. The distal surfaces of spores of $T$. triangulatus are set with a reticulate pattern of anastomosing ridges having a mesh size of about $20 \mu-$ $80 \mu$ (Guennel, 1954); those of T. catenulatus var. marginatus show a discontinuous reticulate pattern of much smaller mesh size. Although the ornamentation and flange of spores of $T$. catenulatus var. marginatus are rather easily torn from the spore body, the lips (lamellae of Guennel, 1954) are sturdily attached to the spore body proper. This latter feature seems to be in contrast with what Guennel (1954) describes for spores of $T$. triangulatus. Evidently the flange, lamellae, and reticulum of spores of $T$. triangulatus constitute a single membranous complex which is easily torn from the spore body. The lips on spores of $T$. triangulatus are often straight when only $10 \mu-20 \mu$ high but become sinuous or fluted when the height at the proximal pole is as much as $80 \mu$; the lips on spores of this variety of $T$. catenulatus are usually straight and may be more than $200 \mu$ in height at the proximal pole. The presence of a lageniculate apex and a welldeveloped flange on the same spore poses the problem of whether these spores are more closely related to the sections Lagenicula or Triangulati. However, the apical prominence of spores of the catenulate group as a whole is the more distinctive feature.

Occurrence.-Spores of this variety are common in the Bedford shale, especially in the lower part, at localities 1, 2, and 3 (pl. 23). One specimen was found in the Bedford shale at locality 6 and one, of questionable affinity, in the Cuyahoga and Black Hand formations (undifferentiated) at locality 7.

Triletes catenulatus var. mixtus n. var.

Plate 7, figure 2

Diagnosis.-Megaspores of medium size, usually laterally compressed and showing varying degrees of asymmetry because of folds modifying shape; uncom- pressed spore body probably spherical. Total length (including apical prominence but excluding spines) ranges from $460 \mu$ to $730 \mu$ (8 specimens measured); width, normal to axis, ranges, approximately because of spore coat folding, from $420 \mu-560 \mu$.

Trilete structures very prominent. Lips form a basally constricted apical prominence $320 \mu-460 \mu$ wide, $180 \mu-270 \mu$ high as measured from base of lips, bearing conical spines $5 \mu-10 \mu$ long and $2 \mu-3 \mu$ in diameter. Trilete rays $200 \mu-280 \mu$ long, forming a small triangular projection at arcuate ridge. Contact areas probably occupy about four-fifths of proximal surface in transverse plane and bear small spines $2 \mu-4 \mu$ in height and $2 \mu-4 \mu$ in diameter.

Distal spines discrete, rather closely spaced, $10 \mu-25 \mu$ in length, uniform in length on any one specimen, and $5 \mu-10 \mu$ in diameter; spines more or less elongate conical, tapering abruptly to a long point. Smaller subsidiary spines sometimes present. Some spines on every specimen joined throughout part of their length or connected by a catenulate bridgelike strand, but not appearing, in plan view, as an overall network, as does ornamentation on typical spores of $T$. catenulatus.

Spore coat $5 \mu-19 \mu$ thick; on one specimen spore coat $13 \mu$ thick distally, $12 \mu$ thick just distal to arcuate ridge, and $5 \mu$ thick at contact area. Spore coat orange red to reddish brown, thinner lips yellow by transmitted light.

Holotype--Plate 7, figure 2, from cuttings of the Cuyahoga and Black Hand formations (undifferentiated), locality 7 , maceration 366 , slide 2 .

Discussion.-Spores of this variety can be distinguished from those typical of $T$. catenulatus and from those of T. catenulatus var. marginatus by their higher basally constricted apical prominence which may cause their preference for lateral compression. Furthermore, most of the distal spines are discrete, a few being of the catenulate type. Flange development such as is exhibited by T. catenulatus var. marginatus is not present on spores of this variety.

The trend from connected ornamentation to discrete ornamentation (spores of $T$. catenulatus as opposed to those of $T$. catenulatus var. mixtus) is also shown by spores of two other species, T. cervicornis and T. eariabilis, which are probably botanically allied to each other and to the group of plants bearing catenulateornamented spores. Spores of $T$. catenulatus var. mixtus as well as those of $T$. variabitis also show the trend towards the development of a basally constricted apical prominence.

Occurrence.--These spores were found in three samples in the Cuyahoga and Black Hand formations (undifferentiated) at locality 7. One specimen was found in the lower part of the Cuyahoga formation at locality 8 (pl. 23). 
Triletes cervicornis n. sp.

Plate 4, figures 3, 3a, 4, 5, 5a-e ; plate 5, figures 1, 1a

Diagnosis.-Megaspores of medium size, usually compressed laterally; overall length (including apical prominence) ranges from $500 \mu$ to $845 \mu$ (19 specimens measured); equatorial dimension ranges from $400 \mu$ to $690 \mu$. Uncompressed spore body probably nearly spherical to slightly oblate.

Trilete structures highly developed, distorted when vertically compressed (pl. 4, fig. 3). Apical prominence of the subdued lageniculate type, on some specimens as much as $300 \mu$ in height (pl. 4, fig. 4), usually equal to or slightly greater in height than length of trilete ray, bearing small spines as much as $10 \mu$ in height. Adjoining spines may show a catenulate connection. Basal lip width about $7 \mu$. Trilete rays extending nearly to margin, about half the diameter of vertically compressed spore body in length. Arcuate ridges inconspicuous, usually obscured by distal ornamentation, about $9 \mu$ wide.

Contact areas generally smooth to granulose, sometimes set with small spines (pl. 5, fig. 1a). Spines on distal surface closely spaced, most thickly set at ends of rays (pl. 4, fig. 5a); all spines variously branched (pl. 4, figs. 3a, 5b-5e). Spines generally $50 \mu-85 \mu$ long, of uniform length on any one specimen; fluted spine bases range from $10 \mu$ to $30 \mu$ in diameter. Some spines have a single base (pl. 4 , fig. $5 \mathrm{c}$ ), branching outwards into 2 to 5 acuminate tips (pl. 4 , fig. 5e); some consist of 2 to 3 separate prolongations basally, joining outward and forming thickest part of spine before branching again ; other spines joined above level of spore coat by catenulate type of span or bridge. No subsidiary small spines present on distal surface.

Spore coat $13 \mu-25 \mu$ thick, thinnest on contact surfaces. Spore coat orange to dark reddish brown when macerated in HF (hydrofluoric acid), yellow to yellowish brown when macerated in Schulze's solution (for example, holotype), as observed by transmitted light.

Holotype.-Uncompressed specimen on plate 4, figures 5 , 5a-e, from the Berea sandstone, locality 5 , maceration 153, slide 10, collection 1-11-14-53.

Discussion.-As was discussed in the general statements on Triletes, spores of this species are probably botanically allied to those of $T$. catenulatus, occurring in the same assemblages, and to those of $T$. variabilis which are present above the stratigraphic occurrences of $T$. cervicornis.

Adjacent spines on spores of both $T$. cervicornis and $T$. catenulatus possess catenulate spans. However, spines of $T$. cervicornis spores are more highly developed, and the catenulate bars are not as continuous from spine to spine as they are on $T$. catenulatus spores.

As yet no specimens showing intergrading characteristics between those of $T$. cervicornis and $T$. variabilis have been found. In general the spores of $T$. cervicornis have a more limited size range, show no tendency to have a basally constricted apical prominence, and do not possess single spines or subsidiary small spines on the distal coat. The spines are shorter generally, more densely spaced and, although exhibiting the same basal fluting as spines of $T$. variabitis, are not demonstrably hollow or composed of two different organic materials. Most of the spores have a thinner distal coat than those typical of $T$. variabilis.

Spines on spores of $T$. cervicornis bear a superficial similarity to those described for spores of $T$. praetextus Zerndt, T. radiosus S. W. \& B. (= T. radiatus Zerndt), and $T$. hirsutus (Loose) in the sense of Dijkstra (= Setosisporites hirsutus of Potonié and Kremp, 1954). Although the spines of the latter three species are branched or basally fused, apparently no specimens show the variety of types found on an individual specimen of $T$. cervicornis or the catenulate type of span above the spore coat. Otherwise the spores bear little morphological resemblance, especially as concerns the apical development.

Occurrence.-Spores of this species are present in various horizons in the Bedford shale at localities 1 , 2 , and 3 , in the upper part of the Bedford shale at localities 8 and 9 , and in the Berea sandstone at locality 5 (pl. 23).

\section{Triletes variabilis $\mathrm{n}$. sp.}

Plate 7, figures 3, 4

Diagnosis.-Megaspores of medium size, usually compressed laterally or obliquely; spore body originally probably nearly spherical. Overall length (including apical prominence) ranges from $520 \mu$ to $1,380 \mu$; maximum width normal to axis ranges from $440 \mu$ to $1,160 \mu$ ( 14 specimens measured).

Trilete structures highly developed. Apical prominence lageniculate, more or less basally constricted, ranges from $150 \mu$ to $200 \mu$ in height and from $200 \mu$ to $600 \mu$ in width, sometimes split apart into three valves. Lips thick, obscuring suture. Contact areas occupy about three-fourths of proximal surface in transverse plane. Blunt to conical processes, $2 \mu-10 \mu$ high and $2 \mu-10 \mu$ in diameter, commonly on lips and contact surfaces; strongly developed spines possess a catenulate type of connecting span. Arcuate ridge marked by development of spines of same length as more distal spines, but more closely spaced.

Distal spines taper gradually from fluted base to thin sharp point and range from $70 \mu$ to $150 \mu$ in length 
and $10 \mu$ to $40 \mu$ in basal diameter; spine bases often filled with pyrite cubes or other mineral matter. Thus, spine bases either originally hollow or at least composed of two different organic substances. Subsidiary distal spines $10 \mu-35 \mu$ long and $2 \mu-10 \mu$ in diameter. Distal spines mostly single or discrete, but several to as many as half of the spines may be joined throughout part of their length or joined by catenulate spans; larger spores of species, like holotype, bear only 3 or 4 such forked or double spines.

Spore coat $19 \mu-28 \mu$ thick; reddish brown by transmitted light and brown by reflected light. Large spines glossy brown to black and small subsidiary spines of lips, contact faces, and distal surfaces, yellow by reflected light.

Holotype.-Spore shown, as photographed by reflected light, on plate 7, figure 4, from Logan formation, locality 7 , maceration 361 , slide 3 , dry mount.

Discussion.-As was discussed under T. catenulatus var. mixtus, spores of $T$. variablis show morphologic trends (as compared to spores of $T$. cervicornis) of the same kind as is shown by spores of $T$. catenulatus var. mixtus (as compared to spores typical of T.catenulatus). Spores of $T$. variabilis have some ornamentation of the catenulate type as is developed on spores of $T$. cervicornis, but many of the spines are discrete and are, furthermore, interspersed with smaller subsidiary spines. Spores of $T$. variabilis possess an apical prominence which tends to be basally constricted, whereas spores of T'. cervicornis possess the subdued lageniculate type apex.

The basally constricted apex, development of discrete rather than connected spines, and the appearance of subsidiary distal spines on stratigraphically younger spores of the catenulate type probably indicate an evolutionary change.

Spores of $T$. variabilis are comparable to those of $T$. horridus (in the sense of Dijkstra, 1946) and $T$. crassiaculeatus (Zerndt, 1937) S. W. \& B., megasporetypes which have been described by Chaloner (1953b) from the cones Lepidostrobus dubius and Lepidostrobus allantonensis, respectively, but have a smaller mean diameter and possess a lower apical prominence. The spore coats of the Triletes variabilis spores have about the same range in thickness as do those of $T$. horridus. Furthermore, the spines of $T$. variabilis are of about the same length as those on spores of $T$. horridus but are interspersed with somewhat longer subsidiary spines. The most significant difference between spores of $T$. variabilis and those of $T$. horridus or $T$. crassiaculeatus is that those of the former possess some spines that are forked or show catenulate joining and spines that are distinctly not of a homogeneous material. The larger of the $T$. variabilis spores, like the holotype, possess fewer forked spines and catenulate spans connecting spines; these spores, if only casually examined with a low-power microscope, might be confused with spores of $T$. horridus or T. crassiaculeatus.

Occurrence.-Spores of this species are the most abundant megaspores found in cuttings of the Cuyahoga, Black Hand, and Logan formations at locality 7 (pl. 23).

\section{Triletes triquetrus $\mathrm{n}$. $\mathbf{s p}$.}

Plate 7 , figures 6,7

Diagnosis.-Megaspores medium to large in size, often compressed laterally or obliquely; compressions rarely having more than one, if any, lateral fold in spore coat. Overall length (including apical prominence) ranges from $1,000 \mu$ to $1,130 \mu$; equatorial diameter ranges from $850 \mu$ to $1,580 \mu$ (10 specimens measured). Spore body originally more or less spherical, perhaps somewhat oblate.

Trilete structures conspicuous. Lips form a more or less subdued lageniculate prominence (pl. 7, fig. 6), $200 \mu-280 \mu$ high at proximal pole as measured from base of lips, $350 \mu-600 \mu$ high as measured from lowest level of arcuate ridge. Trilete rays $300 \mu-450 \mu$ long, terminating at arcuate ridge in small triangular outgrowths (pl. 7, fig. 6) ; suture apparently extends to margin of triangular outgrowths. Contact areas occupy about one-half of proximal hemisphere (pl. 7, fig. 7). Lips and contact faces generally unornamented to slightly granulose; on some spores small spines about $5 \mu$ long or scattered large processes, like those on distal coat, are present along base of lips (pl. 7, fig. 6) or on contact faces. Arcuate ridges as much as $40 \mu$ wide, bear conspicuous spinose processes.

Discrete pointed spines $15 \mu-50 \mu$ long, extend from large bulbous bases $15 \mu-40 \mu$ in diameter, covering distal surface; spines smaller and more concentrated adjacent to contact areas.

Spore coat $35 \mu-50 \mu$ thick. Spore coat dark-reddish brown by transmitted light. Spore, coat brown and distal spines black by reflected light.

Holotype.-Plate 7, figure 6, from cuttings of the Logan formation, locality 7 , maceration 362 , slide 7 , dry mount.

Discussion.-Distal spines on well-preserved specimens show thin pointed shafts extending from bulbous bases. However, the spine tips on many specimens are now broken away, so that the spine bases and remaining shafts present a rather jagged and irregular appearance. Commonly spine bases are filled with mineral matter, as are those on spores of $T$. variabilis, indicating that either the bases were originally hollow or at least composed of two different organic materials. A 
few adjacent spines on every specimen are connected throughout the length of their bases or are connected by a thin strand above the spore coat, like the ornamentation developed typically on spores of $T$. catenulatus. This species and T. triquetrus probably represent related plants.

One of the distinctive features of these spores is the small triangular outgrowths at the ends of the rays, a feature also characteristic of spores of $T$. angulatus (Zerndt). Spores of T. triquetrus, when compared to spores of the European T. angulatus (Zerndt, 1937; Dijkstra, 1946), appear to possess smaller triangular outgrowths, smaller apical prominences and contact areas in proportion to body size, and larger spinose processes. The axial length of spores of $T$. triquetrus is less than or about the same as the smaller spores of $T$. angulatus, but the equatorial diameters have an equivalent range.

Chaloner (1954b) reports $T$. angulatus from rocks in this country of nearly equivalent age to those in which spores of $T$. triquetrus are found. The latter possess smaller triangular outgrowths, lower apical prominences, larger tubercles, and a consistently thicker coat than those described as T. angulatus by Chaloner.

Occurrence.-Although only 10 measured specimens were used for descriptive purposes, spores of $T$. triquetrus are quite common in the well cuttings from the Logan formation at locality 7 (pl.23).

\section{Section LAGENICULA?}

Triletes globulus n. sp.

Plate 8, figures 1, 2, 3, 4, 4a, 4b, 5, 6, 7 :

plate 9 , figures $1,1 a$; text figure 5

Diagnosis.-Megaspores of medium size, commonly compressed laterally or obliquely. Overall outline, including apical extension, prolate circular to subprolate, averaging $620 \mu$ in length (380 $\mu-840 \mu$ for 13 specimens); spore body appears oblate circular to suboblate, commonly between $500 \mu-700 \mu$ in maximum diameter $(58$ specimens measured; fig. 4). Vertically compressed spores nearly circular.

Trilete structures conspicuous. Apical prominence $70 \mu-190 \mu$ high; apex height bears no apparent relation to total spore size, accounting for as much as 32 percent of total length of one small specimen. Lips sinuous and folded, about $14 \mu$ thick, decreasing in height away from apex, increasing to a second height maximum (as much as $150 \mu$ ) more than half way from apex to margin, then decreasing in height abruptly near ray termination (pl. 8, fig. 2). Trilete rays range from $160 \mu$ (dried and shrunken specimen; pl. 8, fig. 7 ) to $300 \mu$ in length, usually $250 \mu-290 \mu$ (19 specimens measured). Contact areas occupying $5 / 8-4 / 5$ of proximal hemisphere, usually wrinkled, sparsely ornamented with tubercles (pl. 8, figs. 4 b, 6) $6 \mu-9 \mu$ high and $3 \mu-15 \mu$ in diameter. Some tubercles small and round (pl. 8, fig. 4b) ; others larger and irregular, appearing as spheroidal aggregates of smaller globules. Tubercles of contact areas more concentrated near arcuate ridge and along rays, occasionally occurring even on lips (pl. 8, fig. 2). Arcuate ridges conspicuous, moderately curved, about $18 \mu$ wide (pl. 8, fig. 5 ).

Distal surfaces sparsely to densely covered with tubercles, larger and more diversified in form than those on contact areas. Tubercles mostly $9 \mu-18 \mu$ high and $18 \mu-27 \mu$ in diameter, at some places twice this size, appearing as if composed of small globules $4 \mu-9 \mu$ in diameter (pl. 8, figs. 3, 4a, 4b). Some prominent tubercles appear basally constricted, shown at left of figure 4 and in greater detail in figure $4 \mathrm{a}$ on plate 8 . One specimen ornamented with, in addition to normal complement of tubercles, a few spines $9 \mu-18 \mu$ long.

Spore coat $18 \mu-31 \mu$ thick distally (18 specimens measured), a little thinner, about $20 \mu$, at contact areas. Spore coat reddish brown and lustrous by transmitted light; shiny jet black by reflected light.

Holotype.-Plate 8, figures 4, 4a, 4b, from the Bedford shale, 3.5 to 4 feet below the siltstone lentil (Sagamore siltstone member), locality 2, maceration 161 , slide 2, collection 8-12-6-53.

Discussion.-The histogram (fig. 5) depicting the variation in maximum diameter of spores of $T$. globulus shows a skewness toward the size minimum. The spores were measured according to their compressed form and are not from the same locality. Originally in deposition they were necessarily subject to sedimen-

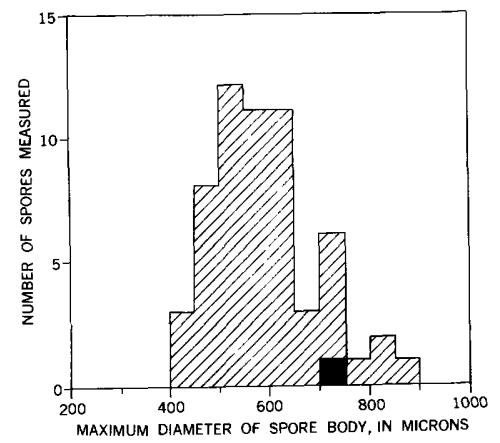

Figure 5.-Histogram showing the size variation of megaspores of Triletes globulus n. sp., based on 58 specimens (dimensions omit apical prominence). Holotype indicated by solid square. 
tary sorting. Under these conditions skewed variations in diameter distribution may be expected.

Tubercles similar to those found on spores of Triletes globulus have been described by Reinsch (1884) as "globular parasitic bodies." He did not recognize these bodies as a botanically integral part of the spore coat but treated them separately as Subtribus II, Globuliformis of Tribus Leptoideae (v. 2). The "parasitic growths" that show some similarity to the tubercles of $T$. globulus are figured on his plate 79, figure 18 a-c (diagnosis 24, p. 25, v. 2), and on plate 80 , figure $25 \mathrm{a}-\mathrm{b}$ (diagnosis 28, p. 25, v. 2). However, the spores bearing these tubercles seem to bear little resemblance to those of T. globulus. These "leptoidean" tubercles, similar to those on spores of $T$. globulus, were found in the Blatterkohle and in beds in the vicinity of Metschowk in the Moscow basin. The beds are, without much doubt, of Early Carboniferous age, and possibly referable to the upper Tournaisian and lowermost Visean (Shvetzov and Vablokov, 1937). According to R. C. Moore (1937) this would correspond in age to the upper part of the Lower Mississippian and lowermost part of the Upper Mississippian series in the North American section.

The tubercles and globules on T. globulus spores are not similar to those sporadically adhering aggregates of globules, possibly of tapetal origin, described by Chaloner (1953b, p. 270) and discussed in detail by Felix (1954, p. 359, 360). Even though there is considerable range in size and form of tubercles on an individual specimen, the surface ornamentation is distinctive and highly characteristic.

Those spores on plate 9 , figures 1 , 1a, three of a tetrad, are probably spores of $T$. globulus, but their opacity prevented further study with transmitted light.

As was noted in the generic discussion of Triletes, spores of $T$. globulus appear to be related to spores of the section Lagenicula that have a rotund body shape, thick spore coat, and prominent trilete structures.

Spores of T. globulus are smaller and have a thinner coat than those of $T$. subtilinodulatus. The latter do not have lips highly developed beyond the apical prominence. These same distinctions apply to an even greater degree in comparison with $T$. splendidus. For spores of T. simplex var. levis Zerndt, the development of the apical prominence is similar, but development of the other trilete structures is different. The shrunken specimen (pl. 8, fig. 7) (shrinkage occurred during mounting) bears a superfical resemblance to those of $T$. agninus and, although the spores of $T$. globulus correspond in size to those of $T$. agninus, the spore coat (in addition to differences of ornamentation and lips) of $T$. globulus is generally much thinner. It seems plausible to regard these high apexed nonprolate megaspores as representative of a group of closely related species of plants.

Occurrence.-Spores are common throughout the Bedford shale at localities 1-3. Spore fragments are present in the upper part of the Bedford shale at locality 6 and in the Berea sandstone at locality 5 (pl. 23). In general, spores of this species are very abundant in the upper part of the Bedford shale of the Cuyahoga County area. As yet, none have been recognized in beds younger than the Berea sandstone.

Triletes aries $n$. sp.

Plate 7 , figure 5 ; pl. 9 , figures $2,2 \mathrm{a}, 3,3 \mathrm{a}$

Diagnosis.-Megaspores of medium size, usually obliquely compressed, originally more or less spherical. Maximum diameter ranges from $680 \mu$ to $1100 \mu$, averaging $850 \mu$ (11 specimens measured).

Trilete structures highly developed. Apical prominence rising abruptly from trilete rays (pl. 7 , fig. $5 ; \mathrm{pl}$. 9 , fig. 2) ; only slightly, if at all, constricted basally; ranging from $100 \mu$ to $270 \mu$ in height, commonly extending from proximal pole $150 \mu$ along ray; thickened and more or less subtriangular in transverse plane. Trilete rays as much as $230 \mu$ long; on some spores rays

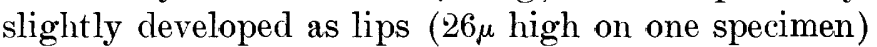
outward from prominence. Contact areas enclosed by low arcuate ridges, occupying about $2 / 5$ to $3 / 4$ of proximal hemisphere (pl. 7, fig. 5 and pl. 9, fig. 3 respectively); usually bearing spines, smaller than but similar to distal spines, and globular tubercles $4 \mu-12 \mu$ in diameter.

Distal surface covered with commonly blunt, sometimes acuminate and reflexed spines extending abruptly from expanded bases (pl. 9, figs. 2, 2a, 3). Spines range from $10 \mu$ to $60 \mu$ (usually $30 \mu$ ) in length and $10 \mu-40 \mu$ in basal diameter; smaller and more closely spaced adjacent to contact areas. One broken and abraded specimen devoid of ornamentation.

Spore coat $25 \mu-50 \mu$ thick. Spores dark-reddish brown by transmitted light; black by reflected light.

Holotype--Plate 9, figures 3, 3a, from the Bedford shale, locality 2 , maceration 163 , slide 1 , collection 9 12-6-53.

Discussion.-Spores of T. aries are slightly smaller than those of $T$. agninus (Zerndt, 1937), possess a more distinct and smaller a pical prominence which does not extend the length of the ray, and have a generally thinner coat and distinct spines (rather than irregular protuberances simulating verrucosity). Spores of $T$. aries are much smaller than those of $T$. splendidus (Zerndt, 1937), have a thinner coat, and possess spinous processes of smaller diameter and different configuration. The apical prominence is similar in form but 
smaller; sutures extend to the proximal pole on spores of both species. Spores of T. aries are similar to those of T. subtilinodulatus (Nowak and Zerndt, 1936) in body size and apical configuration, but possess processes about twice as large and a smaller contact area. Spores of $T$. aries are distinguished from those of $T$. indianensis Chaloner (1954b) by differences of the same kind and magnitude of those noted for spores of $T$. subtilinodulatus; they are generally smaller, possess a lower apex, larger spines, and smaller contact areas. Of all the spores of $T$. aries, those from the Cuyahoga and Black Hand formations (undifferentiated) are most similar to those of $T$. indianensis in size and apical dimensions, but the spine size is greater and the contact areas smaller. The apical prominence of spores of $T$. aries is smaller, less expanded, and relatively opaque.

$T$. aries seems to show its closest alliance with $T$. indianensis which has been recorded by Chaloner (1954b) from the Beaver Bend limestone of Malott (1919) in Indiana, which is correlated with the lower part of the Chester series and thus of somewhat younger occurrence than $T$. aries. The differences between these species is in degree of development of the distal ornamentation, contact areas, and apical prominence. One might conceivably think of $T$. aries as representing an ancestral form that became modified in evolution.

Other possibly related and younger forms are $T$. subtilinodulatus, recorded from Namurian A or Dinantian age beds in Europe by Dijkstra (1946), and other nonprolate lageniculate spores (in the sense of Dijkstra, 1946), such as $T$. agninus and $T$. splendidus. The former species is reported from a coal of Chester or Springer age in Utah by Schemel (1950) and from the Lower Carboniferous of Europe by Dijkstra (1946). Dijkstra reports T. splendidus from the Namurian A and Dinantian of Poland, the Dinantian of Scotland, and questionably from the Namurian C of Turkey.

Occurrence.-Although comparatively rare in individual macerations, spores of this species were found in the Bedford shale at localities 1, 2, 3, 8, and 9 ; in the Berea sandstone at locality 5 , and in the Cuyahoga and Black Hand formations (undifferentiated) at locality 7 (pl.23).

\section{Section APHANOZONATI Schopf, 1938}

\section{Triletes sp. A}

Plate 19, figure 10

Description.-Megaspores small, usually vertically compressed; subtriangular in transverse plane, with bluntly rounded margins at ends of trilete rays; probably originally oblate. Diameter ranges from $285 \mu$ to $400 \mu$.
Trilete structures conspicuous, but not strongly developed. Trilete rays low, straight to slightly sinuous, $12 \mu-14 \mu$ wide, about $120 \mu-180 \mu$ long, extending slightly beyond arcuate ridges. Contact faces smooth, occupying about one-half proximal hemisphere, bounded by low, gently curved arcuate ridges.

Distal spore coat highly granulose to tuberculate. Tubercles parallel sided and blunt, as much as $10 \mu$ in length, usually closely spaced; on some spores well developed only at the arcuate ridge, as on the specimen illustrated. Spore coat $9 \mu-15 \mu$ thick; orange to reddish brown by transmitted light.

Discussion.-These spores are not present in abundance in any one maceration. Specific distinction must await further study.

The spore shown in figure 9, plate 19, possesses much more prominent tubercles and, therefore, is not included with those of Triletes sp. A.

Occurrence.-Spores are not abundant but are present in the Bedford shale at localities 1, 6, and 9 .

\section{Section UNCERTAIN}

Triletes? sp. B

Plate 7, figures $1,1 \mathrm{a}, 1 \mathrm{~b}$

Description.-Megaspores of medium size, usually compressed laterally; overall outline circular to prolate, averaging $960 \mu$ in length $(830 \mu-1,150 \mu$ for 7 specimens). Spore body spheroidal to slightly oblate.

Trilete structures highly developed. Lips $4 \mu-8 \mu$ thick, $110 \mu-200 \mu$ high at proximal pole, tapering gradually to ends of rays, averaging $335 \mu$ in length. Arcuate ridges virtually absent; position marked by conspicuous distal ornamentation. Trilete structures as a whole occupy a little more than half of proximal hemisphere. Contact areas granulose, bearing small protuberances about $20 \mu$ in diameter.

Distal surface granulose, bearing short mammillate spines (pl. 7, fig. 1a), $35 \mu-80 \mu$ high, $40 \mu-130 \mu$ in diameter, each generally possessing a small smooth central papilla about $15 \mu$ in diameter (pl. 7, fig. 1b).

Distal spore coat $25 \mu-50 \mu$ thick, about $15 \mu$ thick at contact areas. Spore coat dark orange to reddish brown by transmitted light; spore coat dull tan to brown, and central papillae glossy and black by reflected light.

Discussion.-Two bifurcate tipped spines (Dicrospora-type), $35 \mu$ and $50 \mu$ long, were noted appressed to one specimen; their connection to the mammillatelike spines was not demonstrable. It is possible that the central papilla of the mammillate spines are in reality basal shafts of longer spines, all of which were broken away during during transport or sample preparation. The texture of the spore coat and the general configuration of the spores seem to support, rather than reject, 
affinity with Dicrospora and the possibility of bifurcate spines. Until obviously well-preserved specimens are found, these spores are questionably referred to Triletes.

The spines now appear generally comparable to those on spores of the Triletes mamillarius-type that Chaloner (1953a) recently described from Sigillarian cones. The apiculi of $T$. mamillarius are occasionally more sharply acuminate. However, spores of the two species are different in original body form: uncompressed spores of T. mamillarius have a planoconvex or concavoconvex form; those of Triletes? sp. B have a more or less spherical form. This difference in original spore form probably indicates a fundamental botanical distinction between the two species of plants. The spines as they now appear on spores of Triletes? sp. B are also comparable in size and shape to those on spores of T. splendidus (Zerndt) especially to those as shown by figure 1, plate 19, in Zerndt (1937). The general body form of the spores of the two species is generally comparable, but those of $T$. splendidus possess trilete structures of different size and configuration.

Occurrence.-Spores and spore fragments have been found, as yet, only in the Berea sandstone of the South Amherst quarries, locality 5.

\section{Triletes spp.}

Plate 5, figures $2,2 a, 2 b, 3,3 a$; plate 17 , figures $10,11,12$; plate 19 , figures $9,9 a, 11$

The spore shown on plate 5 , figures $2,2 \mathrm{a}$, and $2 \mathrm{~b}$, is a unique complete example of one of several types of medium-sized spores that are usually not abundant or well preserved in uppermost Devonian shales of the Chagrin shale and Cleveland member or upper part of the Ohio shale. This spore is about $380 \mu$ in axial length and possesses acuminate spines about $80 \mu$ long. The lips are $170 \mu$ high at the proximal pole. A spore fragment, similar to the spore figured, was found at the same locality, in the Chagrin shale at a horizon 70 feet higher.

The spore shown by figures 3 and $3 a$ on plate 5 is about $245 \mu$ in axial length and possesses distal spines about $12 \mu$ long. 'Trilete structures are unusually high.

The spores illustrated on plate 17 by figures 10, 11, and 12 were probably originally somewhat spherical. On these three spores the trilete sutures appear very short, and originally they were considered as representing Calamospora megaspores. Upon very close examination, however, the trilete rays were found to be quite long but inconspicuous toward their terminations. It is entirely possible that these three spores represent aphanozonate (in the broader sense) megaspores rather than Calamospora megaspores. In any case, the speci- mens are either badly abraded or distorted by mineral grain imprints.

As already noted, the spore shown by figure 9 on plate 19 may be allied to those described as Triletes sp. A.

The specimen illustrated on plate 19, figure 11, shows a resemblance to spores of Triletes fulgens Zerndt (1937). Since it is a single specimen, no further comment seems justified.

Other megaspores of Triletes have been found during this study but are not as abundant or as distinctive as the ones described in detail.

\section{Order LEPIDODENDRALES \\ Family UNCERTAIN}

\section{Genus LYCOSPORA Schopf, Wilson, and Bentall, 1944}

Plate 18, figures 3(?), 3a (?), 4(?), 4a (?)

Type species.-Lycospora micropapillata (Wilson and Coe, 1940) by designation of Schopf, Wilson, and Bentall, 1944 (p. 54).

Description.-Spores trilete, about $18 \mu-45 \mu$ in diameter, flattened oblate originally, circular to rounded triangular in transverse plane (usual plane of compression). Trilete rays extend nearly to margin; suture usually is distinct without much labial elaboration. Spore coat usually thin (about $1 \mu$ ) at proximal and distal poles, thicker at equator, but not distinctly demarcated from the equatorial ridge. Surface smooth to granulose or rugose; on some, ornamentation is more prominent near the equator. Spore equator marked with a short tapering ridge, corresponding to the arcuate ridge, rarely so extended as to resemble typical flange development.

Discussion.-Kosanke (1950) described spores of two species of Lycospora, L. pseudoannulata, and $L$. punctata, which possess rather highly developed equatorial flangelike ridges, $4 \mu-6 \mu$ wide in the former and $2 \mu-3 \mu$ wide in the latter species.

In their discussion of Cirratriradites, Hoffmeister, Staplin, and Malloy (1955b, p. 382) distinguish Cirratriradites and Lycospora as follows:

$* * *$ Cirratriradites includes forms with a distinct marginal flange which is thinner and often lighter in color than the central body. Lycospora has a narrow equatorial girdle on which thickened extensions of the trilete rays are not developed.

They consider Lycospora pseudoannulata, L. punctata, and L. minuta (Wilson and Coe) Schopf, Wilson, and Bentall as spores of $C$ irratriradites.

There is evidence, however, that Lycospora spores, in the same cone, show considerable variation in the width of development of the equatorial ridge or flange. This is shown by the Lycospora-type microspores Felix 
(1954) described in natural association with megaspores of the Triletes mugosus-type from Lepidostrobus diversus cones and by other Lycospora-type spores from a large microsporangiate cone, Lepidostrobus pulvinatus. The spores in the latter cone showed considerable natural rariation. Spores $25 \mu-31 \mu$ in diameter possess a flangelike equatorial ridge $3.6 \mu-4 \mu$ wide; others from the same cone $(15 \mu-19 \mu$ in diameter) possess a ridge $1.2 \mu-2 \mu$ wide. He rather generally compares the larger spores to those of Lycospora parva but more closely compares the smaller spores of the population to those of L. micropapillata. Indeed, he suggests that spores of the latter species (the type species of the genus) might represent immature or abortive spores such as occur in Lepidostrobus pulvinatus.

In contrast, spores of Cirratriradites are apparently allied with the herbaceous heterosporous lycopods (Selaginellales). Chaloner (1954a) describes megaspores of Triletes triangulatus-type and microspores Cirratriradites annulatus-type from Selaginellites suissei Zeiller (="Lycopodites ciliatus" Kidston), an herbaceous heterosporous lycopod cone. More recently Hoskins and Abbott (1956) noted the natural occurrence of megaspores resembling Tritetes triangulatus and microspores of the Cirratriradites annulatus-type in a small bisporangiate strobilus.

Chaloner (1954a) states that possibly there is a general equivalence of Cirratriradites with the herbaceous lycopods as a group. Lycospora on the other hand has arborescent lycopsid affinities. This distinction is probably of ecological as well as phylogenetic significance.

It seems unfortunate that spores of Lycospora that tend toward flange development can be confused with Cirratriradites (Hoffmeister, Staplin, and Malloy, $1955 \mathrm{~b})$. Although they are usually considerably smaller, some spores of Lycospora may be difficult to differentiate from some spores of Cirratriradites. The natural occurrence of equatorial ridges of moderate flangelike proportions on the Lycospora-type spores of Lepidostrobus shows that a purely morphological separation of spores with a flange and spores without is contrary to their probable natural affinity. To be indicative of relationship to Cirratriradites, the flange should be of a prominence comparable to the microspores of Selaginellites. The type species of $\mathrm{Cir}$ ratriradites is fully accordant with this interpretation.

Herbaceous and arborescent lycopods may become harder to distinguish because they were more closely related in Devonian, or perhaps Early Mississippian time, since at that time their stage of evolutionary divergence was certainly less distinct. This possibly, but not necessarily, may apply to their spores also.

Some spores found during this study appeared to compare favorably, on a morphologic basis, with those of Cirratriradites and more rarely with Lycospora. Assignment has been decided by evaluating the degree of general similarity spores of the species have to the respective type species.

Affinity.-In addition to the occurrences mentioned by Felix (1954) and discussed above, Chaloner (1953b) describes Lycospora-type microspores and Triletes rugosus-type megaspores from cones of Lepidostrobus russelianus. He also describes microspores of the Lycospora-type and Triletes horridus-type megaspores from type specimen cones of Lepidostrobus dubius and from other cones, apparently identical, that were found in organic connection with regetative organs assigned to Lepidodendron simile. Felix (1954) also describes Lycospora-type spores associated with microsporangiate cones referred to Lepidocarpon. All the cone studies suggest that Lycospora is authentically identified with the Lepidodendrales.

Occurrence-Kosanke (1950) found abundant spores of Lycospora in Pennsylvanian coals in Illinois. Cross and Schemel (1952) give the upper limit of occurrence for spores of Lycospora as middle Conemaugh in the Appalachian basin. Hoffmeister, Staplin, and Malloy (1955a) give the stratigraphic range of spores of this genus as being from Late Devonian to late Des Moines in age.

In this study, Lycospora? spores were found almost exclusively in the Berea sandstone at locality 5.

Lycospora? sp. A

Plate 18, figures 3, 3a, 4, 4a

Description.-Spores trilete, $36 \mu-48 \mu$ in diameter, flattened oblate, subtriangular in outline in proximal view. Trilete rays faint (pl. 18, fig. 3a), extending to body margin but apparently not onto equatorial ridge. Equatorial ridge as much as $4.5 \mu$ wide, thin at margin (pl. 18, figs. 3a and 4). Spines small, sharply pointed, as much as $3.6 \mu$ in length and $3 \mu-4 \mu$ in width basally (pl. 18, figs. 3 and 4a), present on distal surface of spore body and equatorial ridge.

Discussion.-These spores seem similar in several respects to those of the species next described, Cirratriradites hystricosus; both are subtriangular, possess flangelike rims or flanges, and spinose distal ornamentation. The equatorial flangelike margin of these $L y$ cospora? spores is smaller in proportion to body size than that of spores of corresponding size of Cirratriradites hystricosus. The size and proportions of spores of $C$. hystricosus and of Lycospora? sp. A agree more with their respective type species than with each other. The similarity of their ornamental features may indicate a closer relationship than would be expected be- 
tween the two genera. The spores of Lycospora? are not usually found in association with those of Cirratriradites hystricosus. Whether or not the two genera can be validly distinguished on a morphologic basis in rocks of Devonian or Early Mississippian age is still in question.

The spinose ornamentation of these spores distinguishes them from other spores of Lycospora.

Occurrence.-At present these small spores, isolated and in tetrads, were found rarely in the Berea sandstone at locality 5. One example was found in the Bedford shale at locality 7 (pl. 23).

\section{Order SELAGINELLALES}

Family UNCERTAIN

\section{Genus CIRRATRIRADITES Wilson and Coe, 1940}

Plate 18, figures 1, 2, 5, 6, 12

Type species.-Cirratriradites maculatus Wilson and Coe, 1940 (p. 183), by designation of Schopf, Wilson, and Bentall, 1944 (p. 43).

Description.-Wilson and Coe $(1940$, p. 183) give the following generic description:

* * * Microfossils, triradial: walls medium thickness, translucent to opaque; equatorial fiange present; body of microfossils somewhat triangular; proximal surface triradiate ridges cross equatorial flange; faint striations, rods, or fringe-like secondary layers often present on inner edge of flange. Group A, in part, of Raistrick and Simpson, 1933.

Discussion.-A comparison of spores of Cirratriradites and Lycospora is given in the discussion of $L y$ cospora. The spores of this genus, $40 \mu-100 \mu$ in diameter, are moderately oblate usually compressed in plane of flange, spore body is circular to subtriangular in transverse plane. Trilete rays, usually well developed, extend to margin of spore body and often are expressed as thickenings on the flange. Lips are commonly strongly developed. The thin distinct flange, variable in width and ornamentation, may be radially striate, irregularly thickened and minutely to coarsely serrate marginally. The flange is often more extended at the corners and thus emphasizes the subtriangularity of the spore.

The spore coat is smooth to rugose or ridged; ornamentation is commonly arranged in a radial pattern. The central distal surface may possess irregular areas divided into several sections by ridges.

Cirratriradites spores found during this investigation possess many of the morphologic features common to Cirratriradites spores. The spores are rounded subtriangular in outline with angularity further emphasized by wider development of the flange at the corners. The flange may show bands of irregular density, rodlike thin areas adjacent to the contact of spore body and flange, a radially striate pattern caused by the radial pattern of distal spines, or combinations of these. As far as is known, the distinct distal spinose ornamentation present on these spores has not previously been considered typical of Cirratriradites spores. Similar spinose ornamentation, usually more restricted equatorially, is common on some spores of Densosporites. However, the marginal elaboration of the spores described here is definitely a flange rather than a cingulum.

Upper Devonian examples of Cirratriradites spores are similar to those shown in figures 1 and 2, plate 18 . They generally possess both long prominent distal spines and equatorial spines, the latter connected within a thin flangelike web. On some spores the webbing is weakly developed. Such spores are at least specifically distinct from those, for example, in figure 5, plate 18. Stratigraphic range of the spiny flanged forms is given (pl. 23) under Cirratriradites sp. A, although it is not yet certain that these represent just one species. Those of Early Mississippian age (that is Cirratriradites hystricosus) usually possess a more strongly demarcated flange and less well developed distal spines.

Affinity.-From what is now known from cone studies, the affinity of Cirratriradites is with the herbaceous lycopods. (See discussion under Lycospora.)

Occurrence.-Hoffmeister, Staplin, and Malloy (1955a) report the stratigraphic range of the genus in North America as from Upper Devonian through Pennsylvanian. During the present investigation spores of the genus were found in both Upper Devonian and Lower Mississippian rocks.

\section{Cirratriradites hystricosus n. sp.}

\section{Plate 18, figure 5}

Diagnosis.-Spores trilete, $46 \mu-61 \mu$ in diameter, light to dark yellow; flange distinctly subtriangular to triangular in transverse outline; outline of spore body more rounded. Transverse plane nearly always corresponds to the plane of sedimentary compression. Uncompressed spores oblate distally, flattened pyramidal proximally. Trilete rays usually distinct, somewhat sinuous, extending out onto flange; lips membranous, as much as $4 \mu$ in height at proximal pole. Equatorial flange, minutely serrate marginally, ranges from $6 \mu$ to $16 \mu$ in width along the trilete rays and from $4.8 \mu$ to $10 \mu$ in width interradially; often appearing radially plicate, some with thinner rod-shaped areas in the denser part adjacent to the spore body.

Distal spore coat, $1 \mu-2 \mu$ thick. Distal surface of flange bearing sharply pointed spines $2 \mu-5.2 \mu$ long and $1.2 \mu-4.2 \mu$ in diameter basally. 
Holotype.-Plate 18, figure 5, from the Bedford shale, locality 1, maceration 162, slide 10, collection 17-12-6-53.

Discussion.-The radial pattern of spines in compressed specimens may cause the radially striate or plicate appearance of the flange. The lighter rodshaped areas shown on the flange in figure 5 , on plate 18 may be preservational. They are never as strongly developed as shown by $C$. sp. B in figure 12 on plate 18 . The flange may be partly or wholly torn away on badly abraded specimens.

This species is distinguished from other species of Cirratriradites by the spinose ornamentation of the spore coat.

Occurrence.-Spores of this species are present in the Bedford shale at localities 1-3, 6-9 and in the Cuyahoga and Black Hand formations (undifferentiated) and Logan formation at locality 7. They are especially abundant in the Bedford shale, upper part of the Cuyahoga and Black Hand formations (undifferentiated) and in the Logan formation (pl, 23).

\section{Cirratriradites sp. A}

Plate 18, figures 1,2

Description.-Spores trilete, about $60 \mu-80 \mu$ in diameter; flattened oblate; subtriangular in transverse outline; more commonly, but not always, compressed proximodistally. Trilete rays distinct, extending nearly to margin of flange (pl. 18, fig. 1). Flange, often membranous (pl. 18, fig. 2) or indistinct, as much as $12 \mu$ in width. Spore coat about $2 \mu$ thick. Distal surface of flange set with discrete tapering spines as much as $12 \mu$ in length and $5 \mu$ in diameter basally. Spines on the flange commonly extend beyond margin of flange.

Discussion.-Study of these forms has been cursory. Some spores now considered as $C$. sp. A may later prove to be specifically distinct. Therefore, their stratigraphic range is a preliminary suggestion.

Occurrence.-Spores of this type occur in upper Middle and lower Upper Devonian well cuttings (pl. 23) at localities 7 and 8 (contamination?) and are fairly abundant throughout the Chagrin shale or its equivalent at localities 6,7 , and 8 . Spores are also present in the Bedford shale at localities 1-3, 6-9, and in the Sunbury shale and lower part of the Cuyahoga formation at locality 6. As yet none have been noted in the Berea sandstone.

\section{Cirratriradites sp. B}

Plate 18, figures 6, 12

Discussion.-These spores, considerably less abundant than but generally similar to those of $C$. hystrico- $s u s$, are distinguished by their larger size (as much as $82 \mu$ in diameter) and coarser ornamentation. Spores shown on plate 18 in figures 6 and 12 possess irregular partly interconnected distal ridges as much as $7 \mu$ in width. Sharply pointed spines, $4 \mu-4.8 \mu$ long (like those of $C$. hystricosus), are distributed on the ridges, distal coat, and distal surface of the flange. The flange is serrate, plicate, and wider opposite the trilete rays as in spores of $C$. hystricosus. The flange may possess large irregularly shaped thin areas adjacent to the spore body (pl. 18, fig. 12). It is possible that these thinner areas and apparent coarseness of ornamentation are preservational artifacts. Until more material is examined, it seems advisable to exclude these spores from $C$. hystricosus.

Occurrence.-Specimens, rather rare, were found in the Bedford shale at localities 2 and 7 .

Class, Order, and Family UNCERTAIN

\section{Genus ENDOSPORITES Wilson and Coe, 1940}

Plate 16, figures $1,2,3,4,5,6(?), 7(?), 8(?), 9(?), 10,11$ $13,14(?)$; plate 18 , figures $7(?), 8(?), 9(?), 10(?), 11(?)$; plate 19 , figure $4($ ?) ; text figures $4,6,7$,

Type species.-Endosporites ornatus Wilson and Coe, by designation of Schopf, Wilson, and Bentall, 1944 (p. 45).

Description.-The spores are originally described by Wilson and Coe (1940, p. 184) from the Des Moines series of Iowa as:

$* * *$ spherical or subspherical, possessing centrally a smaller sphere or central body; central structure with triradiate aperture; walls thin, transparent or translucent, colorless.

They also noted the probable equivalence of group C [in part] of Raistrick and Simpson (1933).

Discussion.-As a general rule the spores of Endosporites possess a central spore body enclosed in an inflated bladder which is joined to the central body only on the proximal surface.

Schopf, Wilson, and Bentall (1944) give a more complete description of these spores. They note the irregular folding of the bladder, the common presence of infrareticulation on the distended perisporal bladder, the occasional continuation of trilete rays onto the bladder, and the presence of apical papillae on the endosporal body of some spores.

Kosanke $(1950$, p. 36$)$ states that the size of spores of Endosporites described from this country ranges from $50 \mu$ to $175 \mu$. He, as well as Schopf, Wilson, and Bentall, notes that the encompassing bladder is usually membranous and much thinner than the wall of the enclosed central body. 
Chaloner (1953c) described spores of the Endosporites globiformis-type (Ibrahim, 1932) S.W.\& B. from Lepidostrobus zea Chaloner. Chaloner's results reconfirmed the reconstructed axial section of original spore form as given by Potonié (1952, p. 152, fig. 3) in that the perisporal bladder extends distally completely around the spore body and is not attached to the distal part of the spore body. Chaloner also mentioned the presence of a slight peripheral thickening of the perisporal bladder.

More recently, Potonié and Kremp (1954, p. 171-173, pl. 18, figs. 80, 81) describe spores of Endosporites and present a revision of the reconstructed axial section of spore form as given by Potonié in 1952. They describe spores of Endosporites as possessing a marginal limbus on the bladder, a morphological feature apparently equivalent to the peripheral flange on the inflated wing of Spencerisporites spores as described by Chaloner (1951). On the other hand, Chaloner (1953c) notes a peripheral thickening but not a narrow flange, on the bladder of Endosporites-type spores. Potonié and Kremp describe the peripheral limbus as causing a certain rigidity of the bladder and together with the original flattened umbrella-shaped form causing characteristic proximodistal orientation of compressions. Potonié and Kremp do not discuss whether or not all spores previously assigned to Endosporites were originally umbrella shaped or possessed a marginal limbus.

Seven distinguishable trilete single-bladdered spores, one type of which is referred to another genus, are described in this paper. Four species of Endosporites are new: E. chagrinensis, E. lacunosus, E.? pseudoradiatus, and E.? crassaspinosus. Spores of the three latter species possess some features that have not been considered as characteristic of Endosporites spores. Spores of E. lacunosus possess bladders ornamented only on the distal external surface. Those of E.? pseudoradiatus are of large size and possess a very thick walled bladder and strongly developed trilete rays. Those of E.? crussaspinosur also possess a thick walled bladder, highly ornamented, however, and heavy trilete rays. With the study of more and more singlebladdered spores from rocks older and younger than those containing the type species, it may become necessary to revise the characterization of this genus. It is more than likely that some spores now described under Endosporites. including several described here, are not borne by plants at all closely related to the type species Endosporites ornatus.

Affinity.-Potonié (1954, p. 110-111) reviews the problem of the affinity of Endosporites and refers Endosporites to Sigillariaceae questionably. Prior to this review, Schopf, Wilson, and Bentall (1944, p. 45) described Endosporites as related to some of the Pennsylvanian Cordaitaleans, but Schopf (oral communication, 1955) now regards this relation as doubtful. Chaloner (1953c, p. 109) describes Endosporites globiformis-type spores from a lycopod cone, the affinities of which, however, are not at all clear. (See Potonié, 1954, p. 110-111.)

Occurrence.-Spores of Endosporites are found in rocks of Late Tournaisian to Early Permian age in Europe and Asia (Potonié and Kremp, 1954, p. 183). Hoffmeister, Staplin, and Malloy (1955a) report finding spores of Endosporites in beds of Early Mississippian to early Permian age in North America. They report spores questionably assigned to this genus from the Upper Devonian of western Canada.

Spores of Endosporites chagrinensis are among the most abundant spores in the upper part of the Ohio shale and Chagrin shale of Late Devonian age in Ohio. Spores of E. lacunosus are among the most abundant small spores in the Bedford shale and Berea sandstone of Early Mississippian age (fig. 4). Those of E.? pseudoradiatus are typical of the Bedford shale while those of E.? crassuspinosus are abundant in the Bedford shale, upper part of the Cuyahoga and Black Hand formations (undifferentiated), and in the Logan formation.

\section{Endosporites chagrinensis n. sp.}

Plate 16, figure 10 ; text figure 4

Diagnosis.-Spores trilete, have a central body enclosed in a bladder, usually compressed in proximodistal orientation; ranging from $105 \mu$ to $183 \mu$ in diamater, including bladder, for 27 specimens measured (more than half of these range from $120 \mu$ to $140 \mu$ ). Central body ranges from $64 \mu$ to $100 \mu$ in diameter; ratio of central body diameter to total diameter commonly between 53 to 59 percent with extremes of 50 and 66 percent. Outline of bladder (perisporal?) circular in transverse plane, that of central body (exosporal?) slightly subtriangular. Original form of bladder probably oblate to disk shaped in axial section, that of central body flattened oblate. Bladder attached only to proximal surface of central body, commonly highly folded and, therefore, crenulate at its periphery.

Trilete suture $28 \mu-39 \mu$ long at each ray, fairly distinct, extending nearly to body margin; spore body often split open along suture. No lips, arcuate ridges, distinct demarcation of contact areas, or apical papillae observed.

Spore-body surface appears quite smooth; bladder appears finely granulose, possibly a preservational and not an original characteristic. Bladder membrane 
$0.5 \mu-0.9 \mu$ thick, yellow by transmitted light; central body coat $1.4 \mu-1.9 \mu$ thick, dark yellow to orange brown by transmitted light.

Holotype.-Plate 16, figure 10, from the Cleveland member of the Ohio shale, locality 6 , maceration 442 , slide 5 .

Discussion.-On many specimens, folds of the distal bladder membrane are superimposed on the distal wall of the central body which is not affected by the folding. It is assumed, therefore, that the distal part of the bladder is not connected to the central body of the spore. Furthermore, folds on the proximal surface of the bladder may extend toward the proximal pole as much as $20 \mu$ past the margin of the central spore body without being reflected in corresponding folds of the central body. This feature indicates that not all of the proximal hemisphere of the central body is attached to the bladder. Several specimens were compressed slightly obliquely, but the bladder maintained its circular outline, and there is no indication of a thickened marginal rim. Therefore, the original spore form in axial section would be slightly different in reconstruction, and less disk shaped, than that given by Potonié and Kremp (1954, pl. 18, fig. 81). There can be little question, however, that these Upper Devonian spores would be interpreted as representing Endosporites if they had come from rocks of Pennsylvanian age. There is no adequate basis for generic distinction at the present time.

Several associated smaller spores are very similar to spores of this species. They range from $67 \mu$ to $95 \mu$ in diameter, and possess sutures shorter in relation to body diameter and a central body more subtriangular in outline. They are not identified with $E$. chagrinensis at the present time, but the possibility of close relationship exists.

Spores of E. chagrinensis are comparable to those of Auroraspora solisortus Hoffmeister, Staplin, and Malloy $(1955 \mathrm{~b})$ in the outlines of subcircular bladder and subtriangular central body, in the relative thickness of body wall and bladder membrane, and in the ratio of spore body to the total diameter. However, spores of E. chagrinensis do not have lips developed along the suture and are at least twice the size of those of Auroraspora solisortus.

As a rule the spores of this species are not well preserved. They often are broken.

Occurrence.-The occurrence and relative abundance of $E$. chagrinensis is diagrammatically presented in figure 4. Spores of this species are among the most abundant in the Chagrin shale at several localities. In general the species occur's commonly in the upper 275 feet (abundantly in the upper 150 feet) of the Chagrin shale and in the Cleveland member of the Ohio shale at locality 6 . The spores are also present in the Chagrin shale of locality 8 , occuring abundantly about 125 feet down from the base of the Bedford shale. At locality 7, only one spore of this species was found, that occurring 237 feet down from the top of the Ohio shale (pl. 23).

\section{Endosporites lacunosus n. sp.}

Plate 16, figures 1, 2, 3, 4, 5; text figure 4

Diagnosis.-Spores trilete, possess central body enclosed in a bladder, usually flattened in good proximodistal orientation; range from $53 \mu$ to $103 \mu$ in overall diameter, including bladder, for 31 specimens measured (more than half of these range from $60 \mu$ to $70 \mu$ ). Central spore body ranges from $33 \mu$ to $59 \mu$ in diameter; ratio of central spore body diameter to total diameter commonly between 60 and 70 percent, with extremes of 47 and 81 percent. Bladder and central body both asymmetrically subtriangular in outline, 1 radial extremity usually slightly more acute than the other 2 (pl. 16, fig. 4); uncompressed spore form probably somewhat flattened. Bladder membrane attached to central body only on proximal surface, usually with distal folds in proximodistal compressions; bladder membrane and central body both much folded in lateral compressions.

Trilete rays distinct (pl. 16, fig. 1), with sutures extending to margin of central spore body and persisting as folds on bladder membrane to, or to within a few microns of, peripheral rim. Lips rising gradually to $4 \mu$ in height at apex. Central body with three, often indistinct, apical papillae (pl. 16, figs. 3 and 4 ).

Surface of central body and proximal surface of bladder is smooth. Distal external surface of bladder membrane marked with irregularly spaced oval to circular pits, $0.9 \mu-5.5 \mu$ in diameter and about $1 \mu$ in depth (pl. 16, fig. 4); intervening ridges irregular in width and length, with tiny sharp spinules as much as $1.4 \mu$ in length and about $1 \mu$ in diameter; spinules confined to distal surface beyond the peripheral rim.

Wall of central body usually $1.3 \mu-2 \mu$ thick. Bladder membrane $1.1 \mu-2.3 \mu$ thick at margin of proximodistal compressions, because of thickened peripheral rim (pl. 16, fig. 5) ; proximally and distally, bladder membrane appears $0.7 \mu-1.8 \mu$ thick in optical section measured along folds. Spores appear light yellow to dark brown by transmitted light, depending on preservation.

Holotype.-Plate 16, figure 5, from the Berea sandstone at locality 5 , maceration 153 , slide 23 , collection $1-11-14-53$.

Discussion.-The bladder in the unflattened spore is probably extremely lenticular in form, similar to that shown by Chaloner (1953c, p. 106, text fig. 4, lower left). The peripheral rim of the bladder is thickened 
slightly (pl. 16, fig. 2) as in spores of the Endosporites globiformis-type described by Chaloner (1953c) and maintains its identity even when it is displaced from the margin.

The author prefers to refer to the basic ornamentation on the distal surface of the bladder as lacunose because the pattern of interconnecting ridges around the pits is more irregular and coarses than ornamentation patterns usually described as reticulate. Bladders of spores typical of Endosporites are usually described as having the same kind of emphytic ornamentation on both proximal and distal surfaces (Schopf, Wilson, and Bentall, 1944, p. 45). These authors also suggest that the fine-meshed reticulation pattern, commonly present, is probably on the internal bladder surface, rather than on the exterior. In spores of E. lacunosus, not only is the lacunose (or reticulate) ornamentation and associated spinules on the external bladder surface, but also these features are distinctly limited to the bladder surface distal to the marginal rim. Whether this feature is unique among spores of Endosporites or merely too indistinct to be demonstrated with certainty on spores of some other species is uncertain. More critical studies need to be made to establish this point as it may aid in differentiating the spores of lycopsid affinity (Endosporites) from pollen or prepollen grains of coniferous origin.

The apical papillae are rarely distinct, but more distinct on isolated spores than on spores found in large sporangial masses. The lacunose ornamentation is also much more distinct on isolated spores. The distal bladder spinules are conspicuous on spores in sporangial masses.

Spores of E. lacunosus shown on plate 16 are yellow to light yellow. Specimens having very dark brown coloration and obvious distal ornamentation are abundant in the red shale of the Bedford at locality 8 and in the red upper part of the Bedford shale at locality 1. Some dark specimens are present at most localities but are not always associated with red beds. Where red shales were sampled, however, specimens representing E. lacunosus were invariably darker and displayed conspicuous distal pitting. The differences between the light- and dark-colored spores are probably due entirely to preservational differences.

These spores are similar in size and proportions to those of $E$. pallidus Schemel, but the spores of $E$. pallidus evidently do not possess distally restricted bladder ornamentation or as thick a peripheral rim.

Occurrence.--Spores of Endosporites lacunosus are very abundant in the Bedford shale at localities 1-3, 6-9 (pl. 23 and fig. 4). Spores are also abundant in the uppermost part of the Cleveland member at locality 1 and the Berea sandstone at localities 5 and 9.
Only 1 specimen was found in the lower part of the Cleveland member at locality 1 , and only 2 specimens were found in the lower part of the Cuyahoga formation at locality 8 .

\section{Endosporites sp. A}

Plate 16, figure 11

Discussion.-Two spores of this type have been noted; both possess a central body, fairly thick walled $(2.7 \mu)$, enclosed in a membranous bladder and circular in outline. The total or overall diameter of the 2 spores is $80 \mu$ and $93 \mu$; the ratio of spore-body diameter to total diameter is 65 and 70 percent. Trilete structures are distinct but do not extend to the margin of the central body. Bladder and central spore body are apparently unornamented. Because of the circular outline and the occurence of mineral matter within the central body, which simulates a pitted type of ornamentation in the photograph (pl. 16, fig. 11), these spores seem superficially similar to the form referred to as Zonotriletes microalveolatus, a name unaccompanied by description or reference to type, by Luber and Waltz (1938, pl. 3, fig. 31). More specimens are needed to provide adequate basis for description.

Occurrence.-The figured specimen is from the uppermost part of the Chagrin shale at locality 1, the other from the Berea sandstone at locality 9.

\section{Endosporites sp. B}

Plate 16, figure 13

Discussion.--These trilete spores have a thin finely granulose bladder, $145 \mu-180 \mu$ in diameter, enclosing a thicker walled $(2.7 \mu)$ central body which is only proximally attached to the bladder membrane. Bladder and spore body both are rounded subtriangular in outline in the transverse plane. The ratio of body diameter to total diameter is from 62 to 70 percent. Trilete rays extend onto the bladder as thin, rather vague folds; lips are membranous, as much as $4 \mu$ in height.

Occurrence.-Several specimens were found in the Bedford shale and Berea sandstone at locality 9 and in the Bedford shale at locality 1.

Endosporites? pseudoradiatus n. sp.

Plate 16, figures $6,7,8,9$; text figures $6 \mathrm{~A}, 6 \mathrm{~B}$

Diagnosis.--Spores trilete, rather large for "small" spores, possessing a central body enclosed in a bladder, usually compressed proximodistally; ranging from $175 \mu$ to $470 \mu$ in overall diameter for 38 specimens measured; most specimens from $250 \mu$ to $300 \mu$ in diameter. Enclosed central spore body ranges from $90 \mu$ to $230 \mu$ in diameter, commonly between $125 \mu$ and $150 \mu$; ratio of central body to overall diameter between extremes of 
32 and 65 percent. Bladder moderately subtriangular to nearly circular in outline in transverse plane (pl. 16, figs. 7, 8) ; central spore body distinctly subtriangular (pl. 16, fig. 9). Central body rarely displaced by compression, and, except for short interradial folds (figs. $6 \mathrm{~A}, 6 \mathrm{~B}$ and pl. 16, fig. 7 ), bladder membrane usually not folded. Uncompressed spores probably extremely lenticular, slightly pyramidal proximally.

Trilete structures conspicunus; rays $10 \mu-18 \mu$ wide, gradually increasing in height from radial extremities to as much as $40 \mu$ at apex. Individual rays range in length from 40 to 50 percent of overall diameter, extending nearly to bladder margin (pl. 16, fig. 8). Rays sinuous adjacent to apex, straighter towards extremities, commonly dividing near the margin (pl. 16, fig. 8 ), and on some spores with a near-marginal extension that may simulate a low incomplete arcuate ridge. Lips low, thick, rarely parted, suture apparently restricted to central spore body. Contact areas not distinguished by differences in ornamentation or texture.

External surface of bladder smooth; internal surface usually appears finely punctate, possibly as a result of internal mineral occurrences.

Bladder membrane $3.6 \mu-13 \mu$ thick, more commonly $5 \mu-7 \mu$ along slightly thickened margin (fig. $6 B \quad a-b$ ) and somewhat thinner proximal and distal to peripheral rim; bladder membrane appears thicker in central area where it is attached to proximal wall of central body. Wall of central spore body $1.6 \mu-6.8 \mu$, usually $2.5 \mu-3.5 \mu$ thick, thinner than bladder membrane that surrounds it (fig. $6 B\left(c-c_{1}\right.$ ). Bladder yallow to orange by transmitted light, central body much darker, reddish brown.

Holotype.-Plate 16, figure 7, from the Bedford shale, locality 1 , maceration $40 \mathrm{C}$, slide 10 , collection 4-11-1-52.

Discussion.-Spores of Endosporites? pseudoradiatus are generally much larger than spores typical of the genus. The smallest spores of E.? pseudoradiatus are comparable in size to the largest spores yet unquestionably referred to Endosporites; they are also comparable in size to those of spencerisporites Chaloner (1951). However, spores of Endosporites? pseudoradiatus differ from those of Spencerisporites karczewskii (Zerndt) Chaloner in their original form and in the relation of the bladder to the central body (fig. $6 A, 6 B)$.

The discussion of the reconstructed original form of these spores, here questionably referred to Endosporites, is based on a study of both dissected and entire specimens, using both reflected and transmitted light. The reconstructed axial section is comparable to that shown by Potonié and Kremp (1954, pl. 18, fig. 81) for Endosporites Wilson and Coe, and by

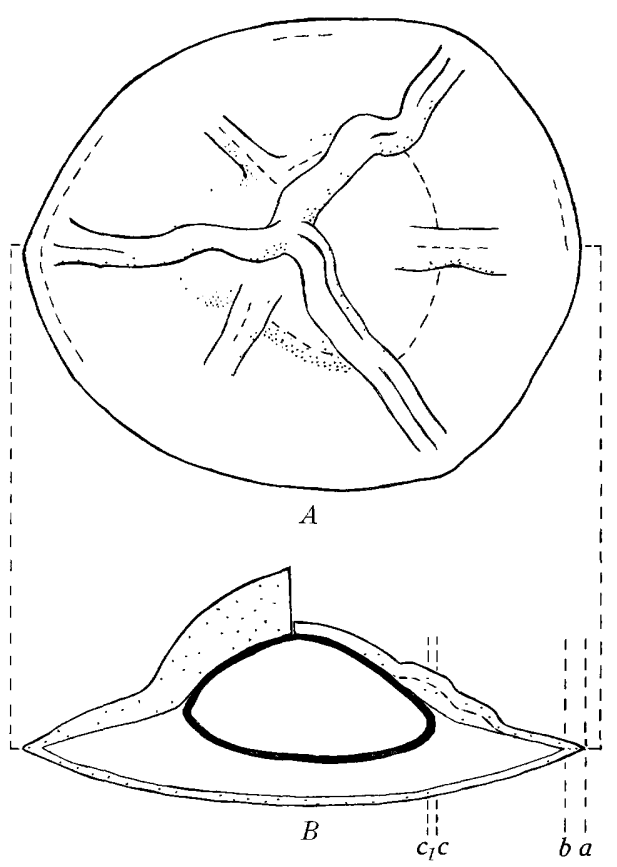

Figure 6. A, Diagrammatic proximal view of a spore of Endosporites? pseudoradiatus $\mathrm{n}$. sp. Dashed lines indicate internal features. $B$, Diagrammatic axial section of same spore. $a-b$ indicates bladder thickness at margin, $c-c_{1}$ indicates inner spore body coat thickness. $\times 200$.

Chaloner (1953c) for microspores of the Endosporites globiformis-type that were obtained from cones of Lepidostrobus zea. Only a part of the proximal surface of the central body is affixed to the bladder. The margins of the central body, as much as $20 \mu$ from the edge, are not involved in the superimposed interradial bladder folds and, to this extent, the wall layers are separate. Similarly, the trilete rays shown by figure 9 , plate 16 , are slightly askew and evidently not affixed to the corners of the central body. The prominent trilete rays, when compressed, may act as buttresses, causing formation of tension folds in the body wall and bladder membrane parallel to the spore margin.

The apex projects above the plane of the bladder when spores of Endosporites? pseudoradiatus are axially compressed. This is accentuated by the stout trilete rays. The central body appears darker by transmitted light because, in addition to the normal thickness of the body walls, the attached proximal bladder membrane also is thickened in this area.

Three morphologic features distinguish these spores assigned to Endosporites? from those of the type species: Larger size, a bladder membrane thicker than the wall of the central body, and a more prominent development of the trilete rays. The spores have in common a marginally rimmed bladder, similar shape, 
and similar original form. Some spores of the Endosporites type evidently functioned as microspores (Chaloner, 1953c), but whether the spores of $E$.? pseudoradiatus functioned as isospores, microspores, or megaspores remains unknown.

The closest comparison of these spores with published material seems to be with those described as spore type A by Lang (1925). The type A spores were found, evidently in abundance, in the Cromarty fish beds in the Middle Old Red Sandstone of Scotland. However, neither of the two specimens figured by Lang (1925, pl. 1, figs. 1,2) show a tendency to develop interradial folds upon compression nor are they as large as typical spores of Endosporites? pseudoradiatus.

Occurrence.-These spores are quite common throughout the Bedford shale at localities 1, 2, and 3 ; a few specimens are present in the Bedford shale at localities 6 and 9 (pl. 23 ).

\section{Endosporites? crassaspinosus n. sp.}

Plate 18 , figures $7,8,9,10,11$; plate 19 , figure $4($ ?) ; text figures $7 \mathrm{~A}, 7 \mathrm{~B}$

Diagnosis.-Spores trilete, have central body enclosed in a bladder, usually compressed proximodistally; ranging from $104 \mu$ to $213 \mu$ in overall diameter. Central spore body ranges from $74 \mu$ to $130 \mu$ in diameter (47-64 percent of total diameter). Bladder distinctly triangular to subtriangular in outline in transverse plane (pl. 18, fig. 8), greatest extension along the trilete rays. Central body subtriangular to rounded triangular (pl. 18, fig. 7), attached to bladder only in area of proximal pole, not joined over margins on proximal surface. Uncompressed spores extremely oblate lenticular, more expanded distally (fig. $7 B$ ).

Trilete rays prominent, sinuous at proximal pole (pl. 18, fig. 8), extending to bladder margin and terminating in a stout spine (fig. $7 B, a-a_{1}$ ). Lips usually well developed, $5 \mu-12 \mu$ high at apex, decreasing in height gradually towards bladder margin. Suture appears to extend nearly to margin of the bladder, but this extension can be distinguished only where lips are torn away or poorly developed (pl. 18, figs. 10 [in part], 11).

Proximal surface of bladder smooth; distal surface ornamented with discrete pointed spines generally ranging from $4 \mu$ to $40 \mu$ in length but usually less than $10 \mu$ (broken?), and from $3 \mu$ to $11.5 \mu$ in basal diameter. Number of spines projecting from one interradial margin vary from 5 to 13 ; typically a spine is developed at each radial extremity. Surface of central spore body smooth to granulose.

Bladder membrane thick, $3.3 \mu-7 \mu$ on margin (fig. $\left.7 B, a_{1}-b\right)$ and distally, apparently thinner on proximal side. Wall of central spore body $1 \mu-3 \mu$ thick (fig. $7 B$, $c-c_{1}$ ), obscured on some specimens by bladder omamentation or folds. Spores yellow to dark orange brown by transmitted light.

Holotype.-Plate 18, figure 10, from the Bedford shale, locality 2 , maceration 163 , slide $\mathrm{A}$, collection 9-12-6-53.

Discussion.-The broken specimen in figure 9, plate 18, shows that the wide margin, otherwise possibly interpretable as a flange, actually consists of the proximal and distal coat of an enclosing bladder. A fairly consistent feature of these spores is a dark apparently thick circular band surrounding the spore body. This band represents the bladder coat in optical section (figs. $7,11, \mathrm{pl} .18)$; the distal bladder spines outside the band can be seen in side view. The bladder curves around and conforms to the expanded shape of the central spore body immediately distal to the central spore body. This configuration may be entirely original or it may be partly induced by compression in the sediments.

Figures $7 A$ and $7 B$ show diagrammatic proximal and cross-sectional views of a spore of $E$.? crassaspinosus as it might appear very slightly compressed. The distal bladder wall has been observed folded over the distal central spore body without any effect on the latter and the central body is occasionally observed displaced

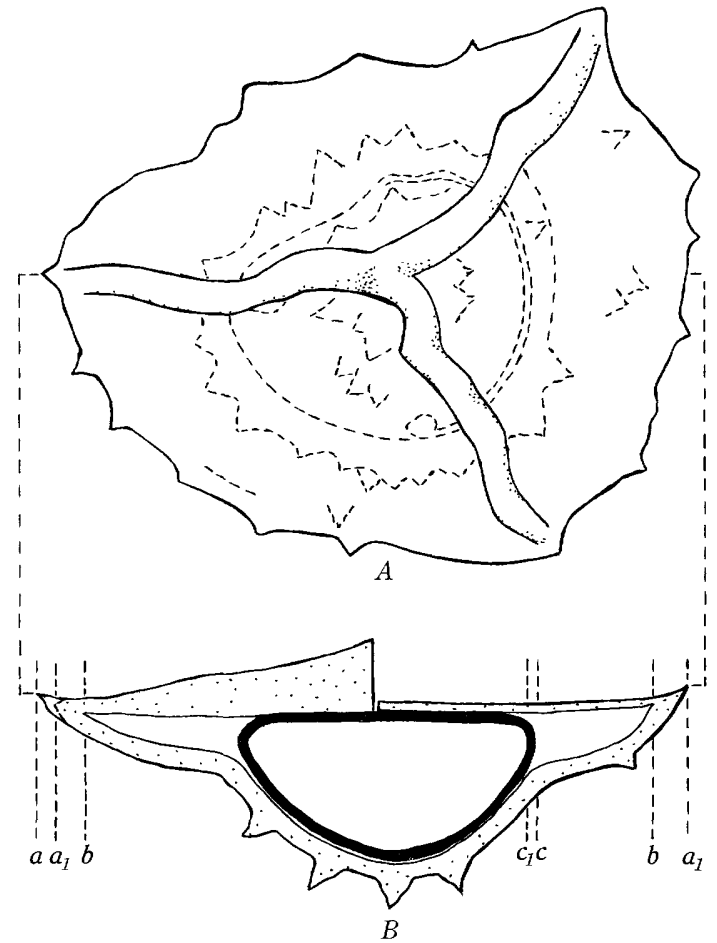

Figure 7.-A, Diagrammatic proximal view of a spore of Endosporites? crassaspinosus n. si. Dashed lines indicate internal and distal features. $B$, Diagrammatic axial section of same spore. $a-a_{1}$ indicates spine, $a_{1}-b$ indicates bladder thickness at margin, $c-c_{1}$ indicates inner spore body coat thickness. $\times \mathbf{5 0 0}$. 
from its central position. The extremely lenticular cross-sectional shape and the buttressing effect of the rays results in an almost invariable preferred proximodistal orientation in deposition and subsequent compression.

Labial elaboration is usually prominent but may be lacking (pl. 18, fig. 11) or partially lacking (pl. 18, fig. 10). It is difficult to determine whether the absence of lips is always a result of preparation or preservation.

Other spores having the same stratigraphic distribution and general dimensions as those shown by figures $7-10$ and 11 on plate 18 have a subtriangular to slightly more rounded shape and a more membranous central body. Many have spines approaching the maximum length given in the description. At present all are considered conspecific. The spore shown by figure 4 , on plate 19 , questionably referred to $E$.? crassaspinosus, may represent the extreme development of the more rounded form and membranous central body.

Spores of E.? crassaspinosus are similar to those of E.? pseudoradiatus in proximal outline and in development of the trilete rays. In contrast, spores of $E$.? pseudoradiatus are generally larger, unornamented, and possess a marginally thickened bladder.

Spores of E.? crassaspinosus are referred to Endosporites because they are comparable in size to large Endosporites spores and possess a single large enclosing bladder. However, the outer membrane, here interpreted as bladder wall, is thicker than that of the central spore body and is distally spinose. These spores differ from those of Grandispora in that the bladder is thicker, the shape more triangular, the ornamentation is distally confined and the trilete rays are much more prominent than in spores of that genus as described by Hoffmeister, Staplin, and Malloy (1955b).

The relationship of this species to any previously described is not at all clear.

Occurrence.-Spores of this species are especially abundant in the Bedford shale at localities 1, 2, and 3, in the upper beds of the Cuyahoga and Black Hand formations (undifferentiated), and in the Logan formation at locality 7. Spores are also present in the Bedford shale at localities 6,8 , and 9 , the Berea sandstone at locality 9 , the Sunbury shale at locality 7 , and the lower part of the Cuyahoga formation at locality 8 (pl. 23).

\section{Endosporites? sp.}

Plate 16, figure 14

The spore shown on plate 16 by figure 14 possesses a trilete central body, wall thickness of $1.4 \mu$, enclosed in a thinner bladder. Diameter of the body is 65 per cent of the total diameter. The specimen is somewhat distorted in preservation and distinctive features may have been obscured.

\section{Subdivision IYCOPSIDA? \\ Class, Order, and Family UNCERTAIN}

Genus DENSOSPORITES (Berry) Schopf, Wilson, and Bentall, Plate 22, figure 13; plate 17, figures 14(?), 16(?), and 18(?)

Type species.-Densosporites covensis Berry, 1937 (p. 157), by designation of Berry.

Description.--Spores trilete, $27 \mu-100 \mu$ in diameter, originally oblate, round to subtriangular in equatorial outline. Trilete rays are usually delicate, may possess lips, and rarely extend to the equatorial margin. Spore coat is greatly thickened at the equator to form a transluscent to opaque circular rim which may taper to a thin margin. The coat decreases in thickness proximally and distally and often is membranous at the proximal and distal poles. Spore coat smooth, granulose to rugose or apiculate; ornamentation more strongly developed equatorially on some spores.

Discussion.-The thickened equatorial area may be simple or divided into zones of different thickness and ornamentation. Hoffmeister, Staplin, and Malloy (1955b) report a transition from simple to zonate margins in spores of one species. Related modifications may be represented among spores Raistrick (1938) assigned to his type $\mathrm{A}$, but these forms have not yet been taxonomically assigned.

Spores of Densosporites found during this investigation are of the smooth type and correspond in this respect with the type species of the genus. Potonié and Kremp (1954) have used the name Densosporites for spinose forms that differ from the type species of the genus, and have applied the name Anulatisporites to spores that correspond best to the species that Berry (1937) originally described and which are assigned to Densosporites here. There is some question whether the spinose development is sufficient basis for generic distinction but, if it is so regarded, the name Densosporites must be retained for the smooth forms that most closely correspond to the species that serves as the nomenclatural type.

Affinity.-The affinity of these spores is as yet unknown, but Potonie $(1954$, p. 115) suggests that this genus is possibly allied with the Lycopsida because of the morphologic transition between spores of Densosporites and Lycospora.

Occurrence.-The youngest occurrence of spores of Densosporites in this country is reported by Cross and Schemel (1952, p. 128 and fig. 4) to be slightly above the Pottsville-Allegheny boundary in the Appalachian 
region. Kosanke (1950) reports these spores as apparently restricted to the Tradewater and Caseyville groups in Illinois. Hoffmeister, Staplin, and Malloy (1955b) described several species from the Hardinsburg sandstone of Late Mississippian age.

The oldest occurrence noted during this study was in the Bedford shale of Early Mississippian age.

\section{Densosporites sp. A}

Plate 22, figure 13

Description.-Spores trilete, $32 \mu-39 \mu$ in diameter, subtriangular in outline, usually proximodistally compressed. Trilete rays simple, faint, not quite extending to the area of equatorial thickening. Spore coat about $4 \mu-8 \mu$ thick equatorially in optical section, becoming membranous as it decreases in thickness toward proximal and distal poles; very light yellow centrally to dark reddish brown marginally, as viewed by transmitted light. Surface smooth to slightly granulose.

Discussion.-The dotted line inside the margin of the spore shown by figure 13 , on plate 22 , is believed to represent the proximal margin of the thickened equator. The thickening, therefore, appears to be most strongly developed slightly distal to the geometric equator. The spores described are consistent in their morphological features, but they are rare. Specific assignment and more complete description is reserved until more abundant material is discovered.

Occurrence.-A few spores of this form of Densosporites were found in the Bedford shale at locality 1 and in the Cuyahoga, Black Hand, and Logan formations at locality 7 (pl. 23).

\section{Densosporites? sp. B}

Plate 17, figures 14, 16, 18

Description.-Spores trilete, $49 \mu-69 \mu$ in diameter; probably originally oblate, nearly circular to rounded triangular in proximal outline; usually compressed proximodistally. Trilete rays simple, centrally distinct but rather vague peripherally, extending nearly to the margin of body cavity as seen in proximal view. Proximal coat of some show a triangular darkened area around the proximal pole (pl. 17, figs. 14, 18). Spore coat $4.4 \mu-9.4 \mu$ thick at the equator in optical section, slightly thinner but not membranous proximally and distally. Surface smooth. Wall dark yellow to orange brown by transmitted light.

Discussion.-The equatorial thickening is not typically developed and it may be these forms should be assigned to a genus other than Densosporites. The equatorial rim could be a thick flangelike modification of the spore coat; it may represent only a thinning of the spore coat on the proximal side. Certainly the average thickness of the proximal and distal portions is greater in this form than in most species of Densosporites, and the greatest thickness is equatorial in specimens normally preserved. A close comparison of the proximal and distal walls has not been possible, however, in material available thus far. The spore shown by figure 18 on plate 17 is tilted slightly in the balsam mount and shows an unusually irregular equatorial thickening and folding.

Occurrence.-Spores of this type have been noted in the Bedford shale at localities 1 and 2 , in the Sunbury shale at localities 8 and 9 , and in the lower part of the Cuyahoga formation at locality 8 .

\section{Genus DICROSPORA n. gen.}

Plates 10, 11, 12 and 13 ; plate 22, figures 15, 16

Type species.-Dicrospora porcata n. sp. (cf. pl. 11, figs. 4 , 5, 5a; pl. 12, fig. 5 ; pl. 22, fig. 15) from the upper part of the Ohio shale at localities 6 and 8, the Bedford shale at localities 1-3, and 9, and the Berea sandstone at locality 9.

Diagnosis.-Spores radial, trilete. Spore body asymmetrical in the axial plane; proximal side flattened or oblate; distal side expanded, even becoming prolate; circular to moderately subtriangular in the transverse plane. Overall shape lenticular, spheroidal or subprolate depending on the degree of apical expansion.

Exclusive of appendages, spores of different species range from about $70 \mu$ to $550 \mu$ in transverse body dimension and from about $100 \mu$ to $455 \mu$ in axial dimension, including the lips.

Trilete rays usually two-thirds of the radius or longer, straight or on some spores undulatory; lips prominent and usually thin. Zonarial (equatorial) ridge usually prominent and integral with the ring of most prominent spines.

Strikingly ornamented by slender spines, from $20 \mu$ to more than $300 \mu$ in length, that tend to be most prominent in the zonarial (equatorial) region, absent on proximal surfaces. Spines bifurcate to multipartite at the tip and often hollow towards their point of basal attachment (pl. 10, figs. 5a-5d; pl. 13, figs. 7, 8, 9). Ultimate terminations variously recurved or hooked, frequently acuminate; some ending in filaments. Apart from the spines, distal surfaces rough, granulose, or smooth; proximal surfaces usually smoother than distal surfaces, some ridged or with small tubercles; but never spinose.

Spore coat usually thinner over the contact areas, thicker distally, varying from about $7 \mu-30 \mu$; density to transmitted light proportional to thickness, thicker portions often appear deep red when centered over a strong light beam. 
Discussion.-The size limits of spores of Dicrospora, as given above, must be regarded as approximate since spores of some species have a preferred compressional orientation. For this reason, both axial and transverse measurements on spores of these species sometimes cannot be given. Small dicrosporoid spores (less than $70 \mu$ in diameter) are present in the Ohio shale but are not described in this report. The upper limit of the size range would be twice as large if Triletes? sp. B is assignable to Dicrospora.

There are several morphologic variations and special morphologic features shown by spores of Dicrospora. Spores of different species show variations of the dicrosporoid configuration but the shape of the proximal area relative to that of the distal area remains fairly constant in spores of the genus, exhibiting extreme flattening in spores of $D$. bedfordi. Spores of several different species of Dicrospora have been found intimately associated with tangled masses of resinousappearing filaments that agree in size and appearance with the terminations of forked spines (pl. 11, figs. 2, 2a). These filaments may have formed as long extensions of the spine tips, now broken away, but their exact significance is not known. Similar tangled threadlike appendages are illustrated for spores described as Selaginellites (Miner, 1932) from the Upper Cretaceous of Greenland. These latter appendages, 8-15 in number, have a funnel-shaped broad base thinning to $3 \mu-4 \mu$ terminally. No implication of botanical affinity should be inferred from this comparison.

Nikitin (1934) interprets the hooked spines on megaspores of Kryshtofovichia as an adaptation for anchoring megaspores in a favorable environment, close to their site of production, rather than as an adaptation favoring wide dispersal. Although the appendages of Dicrospora spores appear fragile, considerable durability in transport is indicated by: (a) their occurrence in marine environments and (b) their persistence on specimens occurring in glacial till derived in part from shale of Devonian and Mississippian age (reference material in "maceration" 169-A, sample transmitted from C. S. Bacon ). Most specimens from reworked deposits, however, have lost delicate appendages.

Whether these spores functioned as megaspores, microspores, or isospores is unknown. The great range in size of spores of Dicrospora is comparable to that exhibited by spores of Calamospora S. W. \& B. which is allied with some of the isosporous-heterosporous articulate groups. However, there is no evidence, other than the considerable range in size, for believing that the plants bearing dicrosporoid spores were heterosporous. Kryshtofovichia Nikitin (1934) is regarded as heterosporous with megaspores and microspores entirely differing in form. Only the megaspores of Kryshtofovichia show resemblances to Dicrospora spores. Possibly some of the smaller spores of Dicrospora may be only immature or abortive (pl. 12 , fig. 8 , spore at upper right) but in general they are well formed and, for this reason, are presumed to have been functional.

Tetradic association (pl. 12, fig. 5), or more especially association in pairs (pl. 11, fig. 5), is common for spores of $D$. porcata. No groups of spores in large sporangial masses like those described by Nikitin (1934) were noted.

There are several scattered notes in the literature describing spores similar to Dicrospora; few of these include both adequate descriptions and binomial designations that are needed as a basis for systematic classification.

Lang (1925) described and illustrated several spore types from the Middle Old Red Sandstone Cromarty fish beds of Scotland and one of the spore types, designated as type $G$, has some characteristics in common with those of Dicrospora. Lang noted two forms of type $\mathrm{G}$ spores: the larger $(\mathrm{G}-1)$ is about $200 \mu$ in diameter, bearing spines about $30 \mu$ long and bifurcate at the tips; the other is very similar to the first, but little more than half as large (about $115 \mu$ in diameter).

Kräusel and Weyland (1929; p. 321-322, 346, figs. 29, $30 ;$ pl. 14, figs. 1,2 ) describe and illustrate bifurcate spined spores from the Middle Devonian beds of Elberfeld, Germany. These are associated with Aneurophyton germanicum and Kräusel and Weyland believe spores of this type were borne in Aneurophyton sporangia. The spores they found isolated are said to range from $60 \mu$ to $200 \mu$ in diameter. Although Kräusel and Weyland (1929, p. 346) also indicate that Aneurophyton spores are $15 \mu$ in diameter, this probably is a misprint. Several Dicrospora species include spores in the $60 \mu-200 \mu$ size range and some of the spores associated with Aneurophyton may be referable to this genus. Unfortunately spores in the Elberfeld beds are more or less opaque, so that critical comparison is impossible.

Arnold (1933, p. 115, fig. 2) illustrates a dicrosporoid spore associated with a heterosporous lycopod strobilus in the Pocono formation in Pennsylvania. This spore evidently is not related to the fructification of Lepidostrobus gullowayi Arnold (1935), as megaspores of a quite different type have been demonstrated in place in the strobilus (Felix, 1954, p. 369). Nevertheless, the presence of dicrosporid spores in the Pocono formation of Mississippian age is of interest.

Nikitin (1934) describes megaspores of Kryshtofovichic a fricani, about $500 \mu$ in diameter, from clays of Late Old Red Sandstone age in central Russia. The distal surface of these megaspores is set with long 
spines, some hollow, evidently bifurcate tipped. The shaft of each spine is nearly cylindrical and long, extending nearly to the tip. This feature is comparable with that shown by Dicrospora sp. (pl. 10, figs. 1, 1a); the general configuration of the spine shaft is similar to that of Dicrospora bedfordi (pl. 10, figs. 2, 2a). The lips of $K$. africani megaspores are ex́tremely high, about $500 \mu$, and often split apart. The megaspores are about the same size as those of Dicrospora amherstensis. It seems quite possible that the spores of Dicrospora and the megaspores of Kryshtofovichia coincide to some degree in their botanical relationship. However, Nikitin based his generic description on association of megaspores, microspores having an entirely different morphology, and megasporangia and microsporangia which he considered part of the same plant. Dicrospora cannot be considered as synonomous..

Arnold (1936) discusses and illustrates spores, apparently identical with Lang's type G spores, from the Scaumenac plant beds along the southern shore of the Gaspé Peninsula. These spores are associated with an Archaeopteris flora. Arnold (1937) also reports type $G$ spores in the Chemung and Ithica-Enfield (Portage) formations of Late Devonian age of the Appalachian region in association with abundant plant parts, especially Archaeopteris. He suggests (1936) that the type G spores in the Middle Old Red, Elberfeld, and Scaumenac floras imply common elements, as yet not fully known, in these floras so widely separated geographically.

More recently Høeg (1942, p. 146-147, pls. 31 and 49) describes and figures several types of bifurcate spined spores, of latest Middle Devonian age, from Mimer Valley in central Spitzbergen. These spores seem most similar to the rare and poorly preserved specimens found in approximately the lower two-thirds of the Ohio shale.

In a recent comprehensive study of spores from Middle and Upper Devonian rocks of the Russian platform (pl. 27), Naumova (1953, p. 26, 51 [description], $52-53,97$, 124; pl. 1, fig. 25 ; pl. 6 , figs. $2-9$; pl. 15 , figs. $12,13$; pl. 18, figs. 24,25$)$ describes a new "subgroup" Archaeotriletes. A translation of her description of this new "subgroup", for which she does not designate a type species, is as follows: Represented by spores with long hornlike protuberances having broadenings on the ends similar to spores of modern water fern of the Azolla type. She briefly describes these spores under 10 specific(?) and one varietal(?) headings in combination with the "subgroup" term Archaeotriletes.

The Russian spores range from $30 \mu$ to $120 \mu$ in diameter and possess numerous spinose processes. The spines of two species? are terminally bifurcate with recurved acuminate tip; spines on the other forms tend to be clavate with incipient bifurcations. Although these spores occur in upper Middle Devonian through Upper Devonian beds in the Russian platform, the specimens illustrated by Naumova are mainly of middle Late Devonian age (Middle Frasnian).

Most of the specimens described here as Dicrospora are larger than those described as Archaeotriletes; show a more distinct development of the terminal spine bifurcations, and possess a greater apical development. Spores of two species(?) of Archaeotriletes possess a zonarium or pseudoflange (arcuate ridge) from which spines radiate. This is well developed in some spores of Dicrospora. The spore mast similar to those typical of Dicrospora is an undesignated specimen figured by Naumova (1953, fig. 2) to represent a "Devonian Azolla type." This spore, $170 \mu$ in diameter, has short $(35 \mu)$ stout bifurcate spines, a very rough distal coat, and, evidently, prominent lips. The specimens from Ohio with multifurcate spine terminations apparently are not known in the Devonian of Russia. None of those described by Naumova can be considered conspecific with spores described here.

Hoffmeister, Staplin, and Malloy (1955a, p. 10, pl. 1 , figs. 4, 6) mention 1 large form of bifurcate spined spore found in the Upper Devonian shales of western Canada and illustrate 2 spores between $50 \mu$ and $60 \mu$ in diameter (excluding spines). These two are smaller than the spores of Dicrospora described in this paper.

The dicrosporoid assemblage reported here is, in part, younger than those previously reported and it seems to show considerably more diversification. In papers mentioned above, there are no illustrations of spore bearing obviously multifurcate spine tips. The most abundant occurrences of spores of Dicrospora in Ohio, as shown from this study, are latest Devonian and earliest Mississippian in age. This is younger than the occurrence described by Lang (1925), Kräusel and Weyland (1929), Nikitin (1934), Høeg (1942), and Naumova (1953, in part), but similar in age to occurrences mentioned by Arnold (1933, 1936, 1937), Naumova (1953, in part), and Hoffmeister, Staplin, and Malloy (1955a). None of the species described under Dicrospora seem the same as those noted by the various authors mentioned, but Lang's type G spores, the megaspores of Kryshtofovichia, and spores reported as Archaeotriletes, probably belong in the same family as Dicrospora. The different species of Dicrospora suggest that considerable diversification took place in this plant alliance during Late Devonian and Early Mississippian time.

Affinity.-Structures analogous, but not homologous, to the bifurcate and multifurcate spine terminations of 
these plant spores also occur on the massulae of Azolla, on perithecia of certain ascomycetes, or zygospores of some kinds of desmids, on some species of hystrichosphaerids, on tests of some chitinozoans, and on statoblasts of some fresh-water Bryozoa. Because this type of spinose structure is present in several groups of unrelated organisms, it evidently cannot be regarded, by itself, as compelling evidence of affinity. It nevertheless is a feature of definite structural specialization and, when taken in combination with other characteristics that serve to validate the comparison, may serve as an excellent basis for taxonomic differentiation.

Both the megaspores of Kryshtofovichia and at least those originally described by Lang, are found in freshwater deposits (Nikitin, 1934, p. 1091; Phemister, 1948, p. 67). Spores of Dicrospora are associated with many land-plant spores in the Berea sandstone at locality 5, that Pepper, de Witt and Demarest (1954) regard as a fresh-water channel sand. They also are associated with abundant fragments of land plants, especially Archaeopteris, in the Appalachian region (Arnold, 1937). On the other hand, spores of Dicrospora are also abundantly associated with Tasmanites, Hystrichosphaeridium, and hexactinellid sponges in undoubted marine environments. In general the evidence strongly supports a terrestrial habitat for plants represented by dicrosporoid spores.

No assignment to any known family or order can be suggested. It is by no means evident that this genus is even fully allied to the Lycopsida although this, of the various possibilities, seems most plausible. Characteristic haptotypic features and highly developed ornamentation suggest that these spores are representative of a specialized group of land plants. The relationship of larger isolated bifurcate spined spores to spores found associated with Aneurophyton is not fully established. The most evident relationships are with the genus Kryshtofovichia described by Nikitin (1934) and with the Archaeotriletes "subgroup" of Naumova. Unfortunately, the alliance of Kryshtofovichia and Archaeotriletes is as problematic as that of Dicrospora.

Occurrence.-Reports of spores similar to those of Dicrospora are scattered throughout the literature, as indicated above. Spore occurrences previously reported, however, are dominantly of Middle and Late Devonian age.

The known stratigraphic range of spores of Dicrospora in Ohio is indicated in plate 23. Spores referable to this genus were found in every locality but were rare at localities 7 and 10 . They are most abundant in the upper part of the Ohio shale (Chagrin shale or its equivalent) and in the Bedford shale.
Dicrospora porcata n. sp.

Plate 11, figures 4,5 , 5a; plate 12 , figure 5; plate 22, figure 15

Diagnosis.-Spores trilete, small in comparison with most megaspores, ranging from $125 \mu$ to $250 \mu$ in axial length (including apical prominence), from $125 \mu$ to $190 \mu$ transversely (17 specimens measured). Laterally and proximodistally compressed specimens equally abundant. Dimensions 1.5 to 2.4 times the measurements given, if overall length of spines is included. Spore body circular to subtriangular in proximodistal compressions.

Trilete structures prominent (pl. 22, fig. 15), least well developed on spores in tetrad association; lips $30 \mu-55 \mu$ in height, membranous; rays $55 \mu-90 \mu$ in length, extending onto zonarial ridge; suture extending only to inner margin of zonarial ridge. Zonarial ridge about $16 \mu$ wide, distinctly demarcated. Each contact surface with 4 to 7 sharp grooves and ridges radiating from apex toward the zonarium, devoid of spines.

Usually about 15 to 30 spines developed on the zonarium and distally, irregularly disposed, tapering from expanded hollow bases into a smooth solid shaft $20 \mu-120 \mu$ in length. Each spine terminated by a characteristic grapnellike bifurcate tip, hooks moderately to strongly recurved.

Body surface granulose, distal coat $7 \mu-12 \mu$ thick, proximal coat varying in accordance with ridge and groove structure. Spore body yellow to orange brown by transmitted light; membranous lips light yellow.

Holotype.-Plate 22, figure 15, from the upper parc of the Bedford shale, locality 9 , maceration $319 \mathrm{a}$, slide 1, collection 2-4-23-53.

Discussion.-Spores of this species are sometimes found joined in tetrads (pl. 12, fig. 5) or more commonly in half-tetrads (pl. 11, fig. 5). Tetrad association of spores suggests immaturity, but tetrads are persistent in the mature spores of certain other groups of plants and probably should be regarded as characteristic of this species. Spores in tetrad or half-tetrad association commonly possess a more pronounced angularity of body form, fewer but stouter spines, smaller contact areas, and a minimum development of lips. Whether they are in tetrad groups or isolated, the individual spores are well formed and presumably equally functional.

The proximal ridges and grooves are consistently present. They appear to have little functional significance and may merely represent characteristic ornamentation.

Grapnel terminations of the spines are best shown in the line drawing ( $p l .22$, fig. 15). Isolated spores have spines with grapnel hooks slightly more recurved 
than those in tetrads (cf. pl. 22 , fig. 15 , with pl. 12 , fig. $5)$. The hollow bases of the spines frequently contain deposits of secondary mineral matter.

Occurrence.-This species is fairly common. It is present in the undifferentiated Ohio and Chagrin shales at locality 7 , the Chagrin shale at locality 8 , the Chagrin shale and Cleveland member at locality 6 , the Bedford shale at localities 1,2, and 3, and the Bedford shale and Berea sandstone at locality 9 (pl. 23).

Dicrospora amherstensis n. sp.

Plate 10 , figures $3,4,5$, 5a, 5b, 5c, 5d

Diagnosis.-Spores trilete, but large, evidently functioning as megaspores. Average diameter of spore body about $525 \mu$; circular to slightly subtriangular in outline in proximodistal compressions. Original body form spheroidal to oblate.

Trilete structures prominent; lips thin and high (more than $70_{\mu}$ ); average ray length about $200 \mu$. Zonarial ridge distinct but inconspicuous (pl. 10, fig. 5), enclosing about 85 per cent of the proximal hemisphere of this spore. Contact surfaces unornamented.

Spines, more than 45 in number on one specimen, developed on the zonarium and distally, tending to be closely and evenly spaced, tapering from expanded bases into a smooth shaft, often curved, about $300 \mu$ in length. Base and shaft both hollow nearly to the tip (pl. 10, figs. 5a-d). Spine tips broadened, nearly flat at the end, armed with two opposed hooks, highly recurved, that correspond with the grapnel type of bifurcation (pl. 10, fig. 5b).

Body surface dull, faintly roughened (pl. 10, fig. 3), or glossy brown to black by reflected light; distal coat $22 \mu-30 \mu$ thick, proximal coat thinner. Spore body reddish brown by transmitted light; lips yellowish.

Holotype.-Plate 10, figures 5, 5a-d, from the Berea sandstone, locality 5 , maceration 153 , slide 1 , collection $1-11-14-53$.

Discussion.-One of the most striking features of these spores, when viewed by transmitted light, is the outline of the hollow spine bases on the distal coat. A striking appearance, when viewed by reflected light, is also afforded by these spores, especially when the spines are broken away and mineralized fillings of spine cavities remain attached to the body. The larger spores assigned to this species are more likely to be broken than those of $D$. porcata described previously.

Occurrence.-Five specimens measured were found in the Bedford shale at localities 1 and 2 and in the Berea sandstone at locality 5. Fragments of spores of this species are common in these beds. Comparable fragments, possibly of spores of this species, were also found in the Chagrin shale, especially at locality 6 (pl. 23).

\section{Dicrospora bedfordi $n$. sp.}

Plate 10, figures 2, 2a

Diagnosis.-Spores trilete, evidently functioning as megaspores, ranging from $330 \mu$ to $480 \mu$ in transverse diameter, slightly greater when obliquely compressed (five specimens measured); subtriangular in outline. Distal surface more oblate than in D. amherstensis; proximal surface flattened; lateral compressions not seen. Uncompressed form oblate or, possibly, lenticular.

Trilete structures prominent; lips very high (as much as $220 \mu$ ), membranous, usually broken or folded across contact areas. Rays $150 \mu-190 \mu$ in length, extending onto zonarium, suture shorter. Zonarium augmented by closely set spine bases and broadly developed into a pseudoflange. Contact surfaces smooth, merging with the inner margin of the zonarium.

Spines (more than 45 in number on illustrated holotype), more than one-third of which radiate from or contribute to the zonarium, stouter and more numerous opposite radial extremities. Spine bases broad, not bulbous, tapering uniformly to join spine shaft, solid, in all $90 \mu-170 \mu$ in length, slightly curved, $8 \mu$ broad near tip. Tips armed with two hooks, strongly recurved, similar to $D$. amherstensis; hooked tips frequently lacking, due to breakage.

Body surface dull by reflected light; distal coat $15 \mu-18 \mu$ thick. Spores reddish orange by transmitted light.

Holotype.-Plate 10, figures 2, 2a from the Bedford shale, locality 1 , maceration $40 \mathrm{~A}$, slide 13 , collection 4-11-1-52.

Discussion.-This species is easily differentiated from those described previously by its relatively short axis and the thickset spines around the pseudoflange margin. Relatively uniform proximodistal compression makes spores of this species appear distinctive.

Occurrence.-Five specimens in good condition and fragmented specimens were found in the. Bedford shale at localities 1 and 2 and in the upper part of the Bedford shale at locality 3 (pl. 23 ).

Dicrospora multifurcata n. sp.

Plate 12, figures $8,8 \mathrm{a}, 8 \mathrm{~b}$; plate 13 , figures $1,2,3,4,4 \mathrm{a}, 5$, $6,7,8,9$; plate 22 , figure 16

Diagnosis.-Spores trilete, small in comparison with most megaspores, ranging commonly from $100 \mu$ to $200 \mu$ in axial length, excluding lips, and from $100 \mu$ to $165 \mu$ transversely (17 specimens measured). Diameter including spines is generally $250 \mu-300 \mu$ and as much as $350 \mu$. Usually compressed laterally; proximodistal compressions relatively rare. Spore body circular or oval in transverse outline; markedly asymmetrical 
in lateral view with proximal surface flattened and distal surface much expanded.

Trilete structures prominent (pl. 22, fig. $16 ;$ pl. 13, figs. 24 ,) ; lips $50_{\mu}-70_{\mu}$ in height, somewhat spatulate in lateral view, membranous; rays $65 \mu-115 \mu$ in length, extending to zonarium, terminated by a slight protuberance, some developed as a spine. Zonarium chiefly demarcated by the bases of zonarial spines. Contact surfaces smooth, inconspicuous.

Spines, usually 7 to 20 in number, more than onethird of which are set along and contribute to zonarium. Spines $40 \mu-120 \mu$ in length (commonly $60 \mu-80 \mu)$, hollow, often collapsed, tapering more uniformly than in previous species from broad bases to $6 \mu-8 \mu$ near tip. Spine tips, armed with 3 to 7 hooks (commonly 6), moderately reflexed and $6 \mu-20 \mu$ in length (pl. 12, figs. 8a, 8b; pl. 13, figs. 7, 8, 9).

Body surface rugose distally. Distal coat usually $8 \mu-11 \mu$ thick, as much as $20 \mu$; proximal coat thimner. Spore body reddish brown by transmitted light; lips and spines yellow.

Holotype.-Plate 13, figures 4, 4a, from the Chagrin shale of the Barberton core, locality 6 , maceration 44 1-B, slide 3, collection 912-792-797.

Discussion.-The considerable range in size observed in this species suggests irregularities in gametophytic development. If heterospory was not completely established in these plants, such a size range might be expected. Larger specimens evidently represent megaspores, but the possibility exists that the smaller individuals may have produced male gametophytes. The smaller spores are well formed and presumably functional regardless of their smaller size.

As in preceding species, characteristics of spines are most diagnostic. The hollow spines are favorite sites for mineral deposits and often contain minute cubes of pyrite (pl. 13, figs. 1, 5, 6; pl. 22, fig. 16). Similar deposits also occur in the central chamber of many spores. The collapse of broad spines lends a characteristic roughened appearance to the shaft and the minute folds, $11 / 2 \mu-21 / 2 \mu$ across, simulate striations, as shown on plate 13 , figure 6 . Spines on some spores tend to be stout throughout their length (pl. 13, fig. 2). The spines are irregularly disposed, and on a few specimens the spines have grown together at the base where too closely crowded. In addition to these features, the many hooks at the tips of spines serve readily to identify this species which shows a greater range of variation in other characteristics.

Occurrence.-Spores typical of this species (that is, D. multifurcata var. multifurcata) are present in the Olentangy shale, Huron member, Chagrin shale, and Bedford shale at locality 8 ; in the upper part of the undifferentiated Ohio and Chagrin shales at locality
7 ; in the Chagrin shale at locality 4 ; in the Chagrin shale and Cleveland member at locality 6 ; in the Bedford shale at localities 1,2 , and 3 ; and in the upper part of the Bedford shale at locality 9 (pl. 23). Abundant specimens were found in the Chagrin shale at localities 4 and 6 , in the Bedford shale at locality 6 , and in the upper part of the Bedford shale at locality 9 .

Dicrospora multifurcata var. impensa n. var.

Plate 12, figure $7,7 \mathbf{a}$

Diagnosis.-Spores similar to those typical of $D$. multifurcata but larger, $240 \mu-300 \mu$ in body diameter, and with longer spines. Diameter including spines 2 to 3 times body diameter (6 specimens measured). Lips as much as $85 \mu$ high at apex. Contact areas smooth and definitely distinguished from rugose zonarium and distal surfaces. Spines $130 \mu-250 \mu$ in length, hollow; spine wall $5 \mu$ decreasing to $3 \mu$ terminally; spine bases expanded $(40 \mu-55 \mu)$, much as in $D$. multifurcata, but shaft proportionately more slender. Tips rarely bifurcate, principally multipartite with as many as 7 hooks, $9_{\mu-15 \mu}$ long. Body surface dull by reflected light, distally rugose; spore coat $18 \mu-28 \mu$ thick.

Holotype.-Plate 12, figures 7, 7a, from the Chagrin shale, locality 4, maceration 169 , slide 2 , collection 1 $1-1-54$.

Discussion.-Most of the specimens noted are broken or badly abraded. Many spine tips have been broken away. On each of several specimens, however, the number of well-defined terminal prongs may range from 2 (bifurcate) to 7 . This type of variation between spines on a single specimen also is characteristic of spores typical of $D$. multifurcata, but spines of the latter never seem to be bifurcate tipped. The consistently larger size of spores of $D$. multifurcata var. impensa seems to support their varietal separation from those typical of the species.

Occurrence.-Spores of this variety are not abundant but are present in the Chagrin shale at localities 4 and 8 , in the Chagrin shale and Cleveland member of the Ohio shale at locality 6 , and in the upper part of the Bedford shale at localities 3 and 9 (pl. 23).

Dicrospora sp. A

Plate 11, figures 2, 2a, 3, 3a

Description.--Spores trilete, typically dicrosporoid in form; axial length, including lips, about $165 \mu$; transverse diameter about $150 \mu$ (4 specimens measured).

Trilete structures well developed; lips thin and about $40 \mu$ in height at apex; rays about $70 \mu$ in length, extending to margin of body. Zonarial ridges distinct, about $14 \mu-20 \mu$ wide, with numerous spines. Contact surfaces ornamented with small irregularly spaced 
hemispherical tubercles $2.5 \mu-5.5 \mu$ in diameter.

Spines numerous, $35 \mu-60 \mu$ in length, with hollow expanded bases $10 \mu-15 \mu$ in diameter and solid shafts, tapering to a dianeter of $2 \mu-4 \mu$ near tip. Spine tips bifurcate, terminal prongs often long (as much as $20 \mu$ ) and tapering, variously curved, of unequal length. Spore coat $7 \mu-19 \mu$ thick distally, thinner $(4 \mu)$ in contact areas; orange brown by transmitted light.

Discussion.-The specimen shown by figures 2 and 2a on plate 11 has terminal prongs unequal in length, tapering to a diameter of about $1 \mu$. The spore is associated with long tangled filaments ( $1 \mu$ in diameter) that agree with the ends of the spines in size and appearance. This suggests that these filaments formed long extensions of the bifurcate spine tips, most of which were broken during sedimentary transport or in preparation of the material. This intimate association of spores and filaments also has been noted for spores of $D$. multifurcata var. impensa, D. bedfordi, $D$. amherstensis, and several other specimens of bifurcate spined spores, specifically distinct and not described in this paper.

The spores of Dicrospora sp. A are similar to those of $D$. porcata in body form but, in addition to differences in spines, are distinguished from that species by contact areas ornamented with scattered tubercles instead of radiating ridges and grooves.

Occurrence.-The four measured specimens were found in the Chagrin shale at localities 4 and 6 , and in the Bedford shale at locality 9.

\section{Dicrospora sp. B}

Plate 12, figure 2

Description.-Spores trilete, probably originally oblate, slightly subtriangular in outline in transverse plane. Diameter $130 \mu-150 \mu$ (5 proximodistally compressed specimens measured). Trilete rays somewhat sinuous, extending nearly one-half the diameter of spore body. Lips about $18 \mu$ in height at apex (1 specimen measured).

Spores apparently possess a flangelike zonarium, $14 \mu-$ $18 \mu$ wide. Spines radiating from edge of equatorial rim and distal coat are relatively delicate with seemingly solid shafts $20 \mu-25 \mu$ in length; spine terminations bifurcate.

Discussion.-Specimens of this type and the one shown in figure 1 on plate 12, which may belong to a different species, are distinctive in possessing relatively short spines.

Occurrence.-A few specimens were found in the Bedford shale immediately below the Euclid siltstone member at localities 1 and 2 .

\section{Dicrospora sp. C}

Plate 12, figures 3, 3a

Description.-Spores trilete, spinose, body asymmetrically oblate; axial length, including apex about $280 \mu$ (3 laterally compressed specimens measured). Apex as much as $125 \mu$ in height, consisting mainly of membranous lips (usually $70 \mu-90 \mu$ in height) ; trilete rays about $95 \mu$ in length.

Distal surface ornamented with numerous flexuous hollow-shafted spines about $100 \mu$ in length. Spines often irregularly bifurcate, with terminal prongs extended and lyrate, rather than recurved, variable, with simple or clavate termination (pl. 12, fig. 3a). Spore coat about $13 \mu$ thick; orange brown by transmitted light.

Discussion.-The spines of these specimens, unlike those of most other spores of this genus, have tips differing greatly in size and shape from one another. It is possible that some of the original terminations have been broken away, so that only a blunt end remains. It seems evident, however, that considerable natural variation exists.

Occurrence.-Two specimens were found in the Bedford shale below the base of the Euclid siltstone member at locality 1 and one was found in the Bedford shale immediately below the base of the Sagamore siltstone member at locality 2 .

\section{Dicrospora spp.}

Plate 10 , figures $1,1 \mathrm{a}$; plate 11 , figures $1,1 \mathrm{a}$; plate 12 , figures $1,4,4 \mathrm{a}, 6$

A number of other forms related to Dicrospora have been found that are not described because of limited or questionably preserved material. Plate 12, figures 4 and $4 a$, shows one of these forms. The spines are unusually well preserved, but the body is opaque due to mineral deposits. It seems more closely related to D. sp. A of species described here, but determination is insecure.

A different type is shown on plate 11, figure 1, in which the spines are straight and long, but relatively thin. An extreme variation is illustrated on plate 12, figure 6 , in which the spines are long and sinuous, being wrapped medusalike around the body of the spore. These types stand in contrast to the spore illustrated in figure 1 , on plate 12 , in which the spines are slender but unusually short. None of these forms are represented by many specimens.

The spcre shown in figures 1 and 1a on plate 10 shows 6 very stout spines, 1 of which has a delicate miniature, but apparently normal, bifurcate termination sur- 
mounting the stout shaft. Spines of most of the spores assigned to Dicrospora tend to have a thickened, bulbous base; in the example figured, this type of basal swelling seems to extend out as a regular investment. of the spine to almost conceal the tip. This spore is very similar to those of the Kryshtofovichia megaspores described by Nikitin (1934) and, when more abundant material is discovered, it may possibly be preferable to consider this spore type as representing a genus other than Dicrospora as treated here.

\section{Subdivision SPHENOPSIDA Class EQUISETINEAE Order EQUISETALES Family UNCERTAIN}

Genus CALAMOSPORA Schopf, Wilson, and Bentall, 1944

Plate 17 , figures $1,2,3,4,5,6,7,8,9$

Type species.-Calamospora hartungiana Schopf, Wilson, and Bentall, 1944 (p. 51), by their designation.

Description.--Spores radial, trilete, probably functioning variously as isospores, microspores and megaspores in different species, originally spherical, or nearly so, developing sharp lunate-lenticular folds upon compression. Trilete rays relatively short, often less than half the spore radius, lacking pronounced labial differentiation. Contact areas may be darkened or possess a slightly different surface texture near the apex (kontakthof). Spore coat usually smooth to slightly granulose or rugose, relatively thin $(<2 \mu$ in spores smaller than $100 \mu)$. The smaller forms $(30 \mu-100 \mu)$ are generally light yellow and translucent. Larger spores may be several hundred microns in diameter and have a coat as much as $15 \mu$ thick.

Affinity.-On the basis of Hartung's (1933) study of spores of six genera of calamarian alliance and on other evidence, Schopf, Wilson, and Bentall (1944) regard Calamospora as allied with the Calamitales and the Noeggerathiales and probably correlative with some Mesozoic equisetaleans.

Occurrence.-Hoffmeister, Staplin, and Malloy (1955a) give the range of spores of this genus as basal Tournaisian to lower Permian in Europe and as Upper Devonian through Pennsylvanian in North America. Naumova (1953) reports the occurrence of calamarian spores of Leiotriletes microrugosus (=Laevigatisporites micromugosus Ibrahim 1933; Calamospora microrugosa [Ibrahim] S. W. \& B.) from beds of Late Givetian age (Middle Devonian) through beds of Famenian age (Late Devonian) on the Russian platform.

Spores of Calamospora described in this paper are chiefly from the Berea sandstone. Other spores, large and small, possessing features described by Hartung as typical of calamarians, are also found, although never in abundance, in the Chagrin shale at localities 6 and 8 , in the Bedford shale at localities 1-3, 6 , and 9 , in the lower part of the Cuyahoga formation at locality 6 and in the Logan formation at locality 7 . Those occurring in the Chagrin shale seem to be distinguished by extremely short trilete rays in a darkened contact area.

\section{Calamospora obtecta n. sp.}

Plate 17, figures 4, 5, 7, 8

Diagnosis.-Spores trilete, completely enveloped by a loosely fitting thin outer membrane (perisporal?), lacking preferred compressional orientation, and appearing circular to subcircular in marginal outline. Maximum diameter, excluding the outer membrane, ranges from $46 \mu$ to $72 \mu$; including the membrane, $55 \mu-$ $76 \mu$. Trilete rays distinct, ranging in length from $18 \mu$ $27 \mu$, usually longer than two-thirds of the spore radius. Labial elaboration absent. No differences in texture or color distinguish the contact areas. Inner spore coat (exosporal?) $1.2 \mu-2 \mu$ thick, minutely granulose to smooth, bright yellow by transmitted light. Outer membrane less than $0.5 \mu$ thick, nearly transparent.

Holotype.-Plate 17, figure 5, from the Berea sandstone, locality 5 , maceration 153 , slide 22 , collection $1-11-14-53$.

Discussion.-These spores are characterized by rather long trilete rays, the absence of coat differentiation in the contact areas, and the presence of a distinctive outer membrane, probably a perisporium. The outer membrane of the holotype specimen is larger, in relation to spore body size, than that enveloping each of the spores shown by figures 4,7 , and 8 on plate 17 . In extreme cases the folds of the outer layer extend $4.5 \mu$ outward from the margin of the spore body. Folds or wrinkles of the outer membrane cross over the suture but are less prominently developed in this region than distally.

The uncompressed specimen shown in figure 4 on plate 17 includes a membranous central body $45 \mu$ in diameter. This might be thought to represent a shrunken endosporal membrane. On the other hand, the spore is split and open; it is possible that this central body is extraneous to the spore. No similar membrane was observed in unbroken specimens.

Calamospora-type spores possessing thin perisporal membranes, frequently separated from the rest of the spore coat, have recently been described by Delevoryas (1955, p. 483) from the calamitean fructification Palaeostachya decacnema. His description seems to imply that the darker contact areas (kontakthof) surrounding the juncture of the trilete rays are morpho- 
logical features of the perispore rather than of the inner spore coat, but these features are lacking from Calamospora obtecta. The fact that spores of Calamospora obtecta retain intact a delicate outer membrane, equivalent to the perisporium, suggests they have not been subject to abrasion in transport. Either distance of transport from their site of origin was relatively short, or the currents were gentle. On the other hand, a fragment of an immature calamitean fructification may have been present, as discussed next (see $C$. obtecta?).

Occurrence.--Spores of $C$. obtecta have been noted only from the Berea sandstone at locality 5 , both compressed and uncompressed (pl. 23).

\section{Calamospora obtecta?}

Plate 17, figures 1, 2, 3, 6

Description.-Spores similar to preceding species but lacking outer (perisporal?) envelope.

Discussion.-Spores occur abundantly with spores of C. obtecta in the Berea sandstone at locality 5 with the sole exception of one example from the Bedford shale (pl. 17, fig. 6). It would seem most plausible that these spores are merely the spores of $C$. obtecta denuded of their outer membranes. However, the presence in the same sample of one sporangial mass of Calamospora spores in which there was no indication of any envelope around individual spores suggests that the smooth spores and the ones with an outer envelope may possibly represent different species of calamarian-type plants. However, these forms all are assigned, with question, to the same species because the sporangial mass may represent an immature state in which an outer spore membrane had not been formed before the fructification was carried away and buried by sediments.

\section{Calamospora sp. A}

Plate 17, figure 9

Description.-Spores trilete, $90 \mu-95 \mu$ in diameter, circular to subcircular in outline, when compressed develop characteristic lunate-lenticular folds. Trilete rays, simple, distinct, about three-fourths the length of spore radius. Spore coat appears darker adjacent to the rays, possibly representing contact areas. Spore coat smooth, $2.7 \mu$ thick.

These are very similar to spores assigned to $C$. obtecta?, except for their larger size and thicker wall. They probably represent a closely allied species of plant.

Occurrence.-Only two specimens were found, those from the Bedford shale at localities 1 and 2.
Order SPHENOPHYLLALES? Family UNCERTAIN

Genus RETICULATISPORITES (Ibrahim) Schopf, Wilson, and Bentall, 1944

Plate 14, figures 1(?), 1a(?), 1b(?), 2(?), 2a(?), 3(?), 3a(?), $4(?), 4 \mathrm{a}(?), 5(?), 6(?), 7(?), 8,9,10,10 \mathrm{a}$; plate 22 , figures $21(?), 22(?), 23$

Type species.-Reticulatisporites reticulatus (Ibrahim, 1933 (p. 33), as designated by Ibrahim.

Description.-Spores trilete, basically triradial in symmetry, about $40 \mu-125 \mu$ in diameter, originally spherical to oblate; irregularly circular to subcircular in marginal outline. Trilete rays may be obscure or possibly absent; when present are variable in development and length in different species. Contact areas are usually not differentiated. Spore coat is about $2 \mu-4 \mu$ in minimum thickness, smooth to punctate; distinctive ornamentation consists of a coarse, often irregular reticulum which may extend proximally, even across the trilete rays.

Discussion.-Schopf, Wilson, and Bentall (1944, p. 34) state that the spore coat appears oftentimes to consist of two membranes. The outer one (perisporal?) when present is thin and integrally involved in the reticulum. The inner membrane (exosporal?) is thicker, sometimes irregular and excentric in development. Not all spores that have been referred to Reticulatisporites appear to possess the outer membrane. Those described in this paper lack an outer membrane and have high interconnecting lamellae, or muri, indistinguishable from the spore coat as a whole.

Affinity.-Some spores of Bowmanites (see Hoskins and Cross, 1943) possess enclosing perisporal membranes folded to a distinct reticulate pattern. Thus the suggestion arose that Reticulatisporites spores, in part at least, might be allied to the Sphenophyllales. Schopf, Wilson, and Bentall (1944, p. 35) state that, in general, spores of this genus bear more resemblance to some of the spores of the Hepaticae as illustrated by Knox (1939) than to those of other groups of Paleozoic age. Mamay $(1954$, p. 83,84, pl. 21$)$ has recently described coarsely reticulate spores from Sclerocelyphus, unfortunately, a genus of unknown affinity. The affinities of Reticulatisporites, therefore, are mainly still in question and it is more than possible that spores now described as Reticulatisporites belong to more than one plant order. Further discussion on this subject appears below in the various species descriptions.

Occurrence.-Reticulate spores, not all referable to Reticulatisporites in its present usage, are known from beds of Late Devonian (Naumova [1953]; Hoffmeister, Staplin, and Malloy [1955a]; this study) to Recent age. Those described in this report are, with few exceptions, of Early Mississippian age. 
Reticulatisporites crassus n. sp.

Plate 14, figures $8,9,10,10 \mathrm{a}$; plate 22 , figure 23

Diagnosis.-Spores trilete, coarsely reticulate, $94 \mu-$ $147 \mu$ in diameter including the highly developed muri; body cavity ranges from $69 \mu$ to $111 \mu$ in diameter. Original form somewhat oblate; lateral compressions shorter axially than in transverse diameter. Proximodistal compressions more numerous than lateral or oblique compressions. Spores generally appear irregularly rounded to oval in outline.

Trilete rays distinct, often split apart (pl. 14, fig. 9; pl. 22 , fig. 23 ), $30 \mu-48 \mu$ long, extending to margin of body cavity. Labial elaboration lacking; rays frequently bordered by low muri. Contact areas not delimited.

Reticulation consists of muri forming an irregular ring slightly proximal to the geometrical equator, and usually 5 to 7 muri radiating distally, forming a network of 7 to 9 lacunae $21 \mu-52 \mu$ in breadth. A lacuna may, on some spores, be almost bisected by an attenuate murus. Attenuate muri usually extend proximally, fully or partially (pl. 22, fig. 23), along each ray, and sometimes intrude into interradial areas. Muri $5 \mu-19 \mu$ high, enlarged at mural intersections; about $6 \mu$ wide, usually pressed into the spore wall so that width is distorted. No perisporal layer is differentiated.

Spore coat ranges from a minimum of $2 \mu-3.5 \mu$ to much thicker along muri. Surface smooth; coat yellow to orange brown by transmitted light.

Holotype.-Plate 14, figure 8, from the lower part of the Cuyahoga formation, locality 8, maceration 148, slide 9 .

Discussion.-The holotype specimen is fairly typical of spores of the species; those shown on plate 14, figures $9,10,10 \mathrm{a}$ and plate 22 , figure 23 possess extreme development of muri though they are typical in size.

Low muri usually border the rays, a feature well illustrated on plate 14, figure 8 (upper left). Partial development of muri along the suture is illustrated on plate 22 , figure 23 . One of the trilete rays on this latter specimen continues as a split through one of the muri. In addition, the proximal coat is partially split.

No consistent pattern of reticulation is evident. If such a pattern were present, the extreme height of the muri and their consequent folding upon compression might make recognition difficult. Distal muri are not consistent in relation to the position of the trilete suture, like that shown by Potonié and Kremp (1954) on spores of Knoxisporites.

These spores, if the interpretation of them as representing Reticulatisporites is correct, extend the maximum size range of spores of the genus, about $20 \mu$. The spores are unique among spores of the genus in possess- ing remarkably high coarse muri which are apparently not perisporal structures as is the reticulum of many spores of the genus.

Spores of this species are generally comparable to spores illustrated by Reinsch (1884, v. 1) on plate 48, figure $271 \mathrm{~B}$ (diagnosis 561) and especially figure $269 \mathrm{C}$ (diagnosis 560), from the Blatterkohle and Stigmarienkohle (Lower Carboniferous) respectively. They are also comparable in size and mural development to those described by Naumova (1938, p. 27, pl. 3, figs. 4, 5) as Aptera amplecta from the Lower Carboniferous of the Moscow basin. Luber and Waltz (1938, p. 12, pl. 1, fig. 7) later redescribed these spores as Azonotriletes am plectus (Naumova). These spores are slightly smaller, do not possess a distinctly reticulate pattern of muri but do show muri bordering the trilete rays. Probably these forms are related to Reticulatisporites crassus but, considering Luber and Waltz's description, it seems doubtful that the two are conspecific.

Occurrence.-These spores were found rarely in the upper part of the Ohio shale at locality 10 and the Chagrin shale at locality 6 ; more abundantly in the Bedford shale at localities $1,2,6$, and 8 ; and are present in the Berea sandstone at localities 5 and 9 , the lower part of the Cuyahoga formation at locality 8 and the Cuyahoga and Black Hand formations (undifferentiated) at locality 7 (pl.23).

\section{Reticulatisporites? fimbriatus n. sp.}

Plate 14 , figures $1,1 a, 1 b, 2,2 a, 3,3 a$; plate 22 , figure 21

Diagnosis.-Spores trilete, prominently reticulate, muri papillate, $69 \mu-115 \mu$ in diameter including reticulate ornamentation, $52 \mu-80 \mu$ in diameter excluding reticulation. Original form somewhat oblate (pl. 14, fig. 2a); laterally compressed specimens shorter in axial than transverse dimensions. Spores usually subcircular in outline, showing no preferred orientation upon compression; compressional folding of the spore coat not common.

Trilete rays distinct (pl. 14, fig. 3a), $21 \mu-28 \mu$ long, usually partly obscured by flattened muri in compressions (pl. 14, fig. 1b). Labial elaboration absent; rays bordered by muri, less delicately fringed than distal muri (pl. 14, figs. 1b, 2a, 3a). Contact areas not delimited.

Reticulation consists of extremely high muri, papillate fringed, that form a distinct rim slightly proximal to the geometrical equator (pl. 14, fig. 2a), and muri radiating distally to form a distal network of 7 to 9 large lacunae as much as $31 \mu$ in breadth (pl. 14, fig. 1a; pl. 22, fig. 21). Muri also usually extend along the rays (pl. 14, upper margin, fig. 2a) and sometimes extend onto interradial surfaces. Muri $8 \mu-21 \mu$ high and 
about $3 \mu$ wide (tangential to surface), highest at mural intersections. Muri incised deeply along the top to about half their height, appear fringed; papillate segments $1.6 \mu-3 \mu$ in diameter (pl. 14, figs. $1,2,3$; pl. 22 , fig. 21). Papillae blunt, clavate or slightly taper pointed; often curved on compressed specimens ( $p l$. 22 , fig. 21). No perisporal layer is differentiated.

Spore coat ranges from a minimum of $2.1 \mu$ to $3.1 \mu$ to much thicker along muri. Surface smooth; coat yellow to orange and dark brown by transmitted light.

Holotype.-Plate 14, figures 1, 1a, $1 \mathrm{~b}$ and plate 22, figure 21, from the Bedford shale, locality 1, maceration 40B, slide 16, collection 4-11-1-52.

Discussion.-The spores shown on plate 14, figures $1-3$, are typical specimens; that in figure la shows relatively few muri deeply dissected, that in figure 3a shows more muri (and smaller lacunae) less deeply fringed. The mural papillae on the spores found in the Cuyahoga and Black Hand formations (undifferentiated) are slightly coarser and more widely spaced than is typical. Since the ornamentation on the spores of $R$. ? fimbriatus is so dissimilar from that of previously described spores of Reticulatisporites, this species is referred only questionably to that genus.

Spores of Aptera spinosa (Naumova, 1938, p. 27, pl. 3 , fig. 3) from the Lower Carboniferous of the Moscow basin appear very similar in outline to those of Reticulatisporites? fimbriatus. However, Luber and Waltz (1938, p. 13, pl. 1, fig. 13), in describing the same forms (as Azonotriletes spinosus (Naumova) Waltz), made no mention of a basic reticulate pattern, nor does their illustration show such a pattern.

Spores of Reticulatisporites muricatus Kosanke possess somexwhat plicate and folded muri superficially resembling those of $R$.? fimbriatus.

Occurrence.-Spores typical of this species (that is, $R$. fimbriatus var. fimbriatus) are quite common in the Bedford shale at localities 1-3, 6, and 9, and the Berea sandstone at locality 9 ; five specimens were found in the Cuyahoga and Black Hand formations (undifferentiated) at locality 7 (pl.23).

\section{Reticulatisporites- fimbriatus var. spathulatus n. var.}

Plate 14, figures $4,4 a, 5$; plate 22 , figure 22

Diagnosis.-Spores similar to those typical of the species but with more variable ornamentation; $65 \mu-$ $120 \mu$ in maximum diameter, $52 \mu-84 \mu$ in diameter excluding reticulate ornamentation.

Trilete rays usually distinct, $21 \mu-31 \mu$ in length, bordered only terminally by low muri (pl. 14, fig. 5).

Reticulate pattern of ornamentation similar but less obvious than in the type variety, due to the extreme dissection of muri and development of spatulate mural processes. Muri more coarsely and deeply dissected or fringed (pl. 14, figs. 4, 5; pl. 22, fig. 22), segments variable, spatulate (especially pl. 14, fig. 5). Spatulate segments coupled with fringed mural segments, as on the type variety, are present on some specimens (pl. 14 , figs. 4,5 ; pl. 22 , fig. 22 ). Spatulate mural processes up to $10 \mu$ in basal breadth, often clavate or partite terminally.

Holotype.-Plate 14, figures 4, 4a, and plate 22, figure 22 , from the Bedford suale, locality 1 , maceration $40 \mathrm{~B}$, slide 15, collection 4-11-1-52.

Discussion.-Fragments of spore coat (in which observation is not confused by double layers of ornamented spore coat) have been found to possess both deep and more shallow types of incision in the same mural network. This range of variation is characteristic of $R$.? fimbriatus var. spathulatus. The specimen shown on plate 14, figure 5, possesses the most extreme development of broad-tipped partite processes yet observed; fringed muri similar to those of the typical variety of the species are also present on this specimen. Emphasis is placed on the differences of ornamental structure in distinguishing spores of $R$.? fimbrictus var. spathulatus from those typical of the species.

Spores of this variety seem morphologically similar to some spores that have been assigned to Raistrickia S.W. \& B. The spatulate processes are similar in size, flattened aspect, and in terminal shape, to the ribbonlike projections possessed by spores of $R$. crocea Konsanke. As far as is known, low ridges connecting spines of Raistrickia spores in a reticulum have not been described. Possibility the resemblance noted here is purely coincidental. On the other hand, it is possible that Reticulatisporites? fimbriatus and $R$.? fimbriatus var. sputhulatus are both related to later plants of Pemnsylvanian age bearing more typical Reticulatisporites spores, and also ancestral to Raistrickia. Some Ruistrickira-type spores are known from filicinean (Schizaeaceous) sporangia (Radforth, 1938).

Spores of Reticulatisporites are known from Upper Devonian and Mississippian rocks (Hoffmeister, Staplin, and Malloy, 1955a; this study). The earliest occurrence of typical Raistrickia spores in North America is reported from the Hardinsburg sandstone (Chester series) by Hoffmeister, Staplin, and Malloy (1955b). At least the ages of known occurrences of spores of the two genera do not contradict the possibility of relationship.

Occurrence.-Spores of Reticulatisporites? fimbriatus var. spathulatus are not common; they are present 
in the Bedford shale at localities 1 and 2 and the Cleveland member of the Ohio shale at locality 6 (pl. 23). At the latter locality the spores are not associated with spores typical of the species. However, the typical spores do occur in immediately younger horizons at this locality.

\section{Reticulatisporites? spp.}

Plate 14, figures 6, 7

Discussion.-The two spores shown on plate 14, figures 6 and 7 , are fairly large (about $120 \mu$ in diameter), each possesses a wide equatorial rim (mural?) which joins distal muri or thickened areas in the coat. Neither spore possesses a definite reticulum as do the others described here. Spores of Canthospora n. gen. (p. 67), in comparison, may possess a central distal thickening, but this does not diverge from the equatorial rim.

Interpretation of the two spores (especially that shown on pl. 14, fig. 6) is further hindered by poor preservation.

Occurrence.-Both specimens are from the Bedford shale at locality 1.

\section{Subdivision PTEROPSIDA Class FILICINAE \\ Order FILICALES [in part] \\ Family UNCERTAIN}

Genus PUNCTATISPORITES (Ibrahim) Schopf, Wilson, and Bentall, 1944

Plate 17 , figures $13,15,17,19$; pIate 18 , figures $16(?), 17(?)$, $18(?), 19(?) ;$ pIate 22 , figure 14

Type species.-Punctatisporites punctatus (Ibrahim) Ibrahim 1933 (p. 21), by designation of Ibrahim.

Description.-Spores trilete, from $25 \mu-120 \mu$ in diameter, round to subtriangular in transverse outline, showing no preferred compressional orientation. Trilete rays usually distinct, variable in length and in labial elaboration. Contact areas indefinite. Spore coat variable in thickness, usually $2 \mu-4 \mu$, with subdued but various types of ornamentation (smooth, granulose, minutely punctate or reticulate, and other types).

Discussion.-Many species referred to the genus Punctatisporites are suspected of having diverse natural affinity. The genus has served as a receptacle for some of the generalized spore types that may never be precisely assigned. Potonié and Kremp (1954) have recently segregated some kinds of spores with distinctive ornamentation, and referred them to other genera on the basis of their morphologic features. Even when the genus is interpreted in this restricted sense, Potonié (1954) considers Punctatisporites as gen- erally allied to the Psilopsida and Pteropsida (Filicales and Cycadofilicales?). This genus is chiefly a taxon of convenience.

In this report, species based on spherical to nearly spherical levigate spores are referred to Punctatisporites. One species having spores of more distinctive shape and ornamentation may eventually be assigned to another genus. For the present, however, these are questionably assigned to Punctatisporites. Some species that might be referred to Punctatisporites by other workers are referred to Verrucosisporites and to Anapiculatisporites in this paper. Because distinctive features in Punctatisporites are obscure, little emphasis has been placed here on problems of speciation.

Occurrence.-Various species of Punctatisporites are found in rocks ranging in age from Devonian to Recent (Hoffmeister, Staplin, and Malloy 1955b, p. 391). Spores of the genus have been identified in Upper Devonian and Lower Mississippian rocks of Ohio and some of them are assignable to a few forms described below.

\section{Punctatisporites of. P. nitidus Hoffmeister, Staplin, and Malloy, 1955}

Plate 17, figure 17

Description.-Spores trilete, $32 \mu-41 \mu$ in diameter, circular in proximal outline, compressional folds common. Trilete suture distinct; rays about $13 \mu-14 \mu$ in length, extending nearly to margin; suture margin simple. Spore coat smooth, thick $(2 \mu)$ in relation to spore size, orange brown by transmitted light.

Discussion.-These spores are very similar to those described by Hoffmeister, Staplin, and Malloy 1955b, p. 393-394, pl. 36, fig. 4) as Punctatisporites nitidus, in size, lack of ornamentation, coat thickness, and in the development of a simple trilete suture. The above authors state that the trilete rays are approximately twothirds the spore radius. On the spore shown on plate 17, figure 17 , the rays are a little longer, but this difference may not be significant. Those from the Logan formation are more closely similar to $P$. nitidus.

Occurrence.-These spores are present in the Bedford shale at localities 1,2, and 6 and in the Logan formation at locality 7.

\section{Punctatisporites sp. A}

PIate 17, figures 13,15

Description.-Spores trilete, $58 \mu-70 \mu$ in diameter, subcircular to subtriangular in outline. Trilete suture distinct; rays about $24 \mu-29 \mu$ in length. Spore coat $3.6 \mu-4.6 \mu$ thick, smooth, dark yellow to orange brown by transmitted light. 
Discussion.-The spore shown on plate 17, figure 13, is folded and slightly distorted by compression. The specimen shown on plate 17 , figure 15 , is poorly preserved, seemingly corroded.

Occurrence.-Three similar specimens have been noted; one in the Cleveland member of the Ohio shale at locality 1 , one in the Bedford shale at locality 2 , one in the Sunbury shale at locality 8 .

\section{Punctatisporites sp. B}

Plate 17 , figure 19 ; plate 22 , figure 14

Description.-Spores trilete, $49 \mu-52 \mu$ in diameter, originally probably nearly spherical to oblate (pl. 17, fig. 19), circular to rounded subtriangular in proximal outline. Trilete rays simple and distinct, four-fifths the spore radius in length. Spore coat smooth, $2 \mu-3 \mu$ thick and of uniform thickness, dark yellow to yellow brown by transmitted light.

Discussion.-These spores are similar to the smallest spores of Punctatisporites? callosus Hoffmeister, Staplin and Malloy (1955b, p. 392, pl. 39, fig. 7) but possess longer trilete rays.

Occurrence.-These specimens are from the Bedford shale at localities 2 and 6 and the Logan formation at locality 7 .

\section{Punctatisporites? logani n. sp.}

Plate 18 , figures $17,18,19$

Diagnosis. - Spores trilete, $55 \mu-84 \mu$ in diameter, originally expanded distally and flattened proximally, subtriangular in outline (pl. 18, fig. 18), commonly compressed in proximodistal orientation, rarely folded.

Trilete rays usually distinct, extending to the equator; lips membranous, as much as $3 \mu$ in height at proximal pole (pl. 18, fig. 17).

Proximal surface usually smooth. Distal surface bearing small apiculations $2.5 \mu-3.1 \mu$ in height, $2 \mu-4 \mu$ in basal diameter, apiculi larger and more densely spaced towards the distal pole (pl. 18, fig. 19). Each small protuberance is more or less round in plan view, is elevated 1 or 2 microns above the base, and is abruptly terminated obtusely, coming to a point. Spore coat below the level of apiculations, $1.2 \mu-1.9 \mu$ thick, slightly thinner proximally, light to dark yellow by transmitted light.

Holotype.-Plate 18, figure 19, from the upper part of the Logan formation, maceration 361, slide 2.

Discussion.-Although the proximal surface is usually smooth, the largest specimen examined possesses proximal apiculi as much as $1.2 \mu$ in height and about $0.5 \mu$ in diameter without expanded bases. These are similar to the terminal parts of the more characteristic distal apiculi. The more robust and denser ornamen- tation towards the distal pole gives some spores the appearance of possessing a central spore body, but no evidence of a central body has been found. ${ }^{6}$ The spores have a characteristic beaded appearance when viewed at low magnifications.

Where spores of this species are not fully compressed, the corners are usually somewhat inclined toward the proximal pole (pl. 18, figs. 17,19 ), resulting in an outline of deceptively rounded appearance. They are less spherical than the photographs suggest and these spores are not to be considered typical of Punctatisporites. They are, in fact, ornamented so distinctively that one may anticipate the taxonomic segregation of this species from more generalized forms usually assigned to Punctatisporites. However, at the present time no more definite relationship can be suggested than that already indicated, and assignment to a new genus might be premature.

Occurrence.-These spores are very abundant in the Logan formation at locality 7 (pl. 23).

\section{Punctatisporites? sp. C}

Plate 18, figure 16

Description.-Spores trilete, $57 \mu$ and $74 \mu$ in diameter, probably originally spherical. Trilete rays distinct, two-thirds the spore radius in length; suture margins simple. Spore coat $1.6 \mu$ and $2.9 \mu$ thick; ornamented distally and proximally, except for a small vaguely defined contact area, with acuminate apiculations, $1.5 \mu-$ $2 \mu$ and $2.3 \mu$ long, $1.5 \mu-2.3 \mu$ and $2.5 \mu$ in diameter, apiculi spaced $2 \mu-3 \mu$ and $3 \mu-4 \mu$ apart.

Discussion.-Two specimens were found, similar in morphologic features and proportions but of different size. The range of dimensions given above includes both specimens, the larger of which is illustrated (pl. 18, fig. 16).

Occurrence.-The smaller spore was found in the Bedford shale at locality 2, the larger in the Berea sandstone at locality 5 .

\section{Order FILICALES? \\ Family UNCERTAIN}

Genus GRANULATISPORITES (Ibrahim, 1933) Schopf, Wilson, and Bentall, 1944

Plate 22, figures 10, 11

Type species.-Granulatisporites granulatus Ibrahim, 1933 (p. 21), by designation of Ibrahim.

Description.--Spores trilete, originally oblate, usually found in proximodistal compression, appearing rounded triangular with concave to convex sides, in the

${ }^{8}$ During a recent examination of the type material (maceration 361 , slidie 2), a single torn specimen, $74 \mu$ in overall diameter, revealed an extremely membranous central body, $42 \mu$ in diameter. 
transverse plane. The known size range is from about $25 \mu$ to $85 \mu$ in diameter (Kosanke, 1950 ).

Trilete rays usually distinct and long; lips, if present, are generally not prominent. Contact areas very rarely differentiated (known only in one species).

Spore coat generally less than $2 \mu$ thick, ornamentation various - (levigate, granulose, punctate, verrucose, spinose, setaceous, or reticulate).

Discussion.-Schopf, Wilson, and Bentall (1944) suggest a possible affinity with the Filicales but point out that there will be difficulty in definitely correlating the genus with any single suprageneric plant group. In addition, Potonié and Kremp (1954) suggest a possible affinity with the Cycadofilicales. This genus, like Punctatisporites, may principally represent a taxon of convenience.

Occurrence.-Spores of Granulatisporites are reported from strata as young as early Permian (Potonié and Kremp, 1954, p. 183) and as old as Late Tournaisian (Osage in part). Spores of this genus were found only in the upper part of the Cuyahoga and Black Hand formations (undifferentiated) and in the Logan formation in this study. These beds are probably generally correlative with those of Late Tournaisian age in Europe (Cross and Hoskins, 1952, fig. 2, p. 115).

\section{Granulatisporites logani n. sp.}

Plate 22, figures 10, 11

Diagnosis.-Spores trilete, subtriangular in outline, generally proximodistally compressed; ranging from $49 \mu$ to $76 \mu$ in diameter, commonly over $60 \mu$. Interradial margins slightly concave to slightly convex; margins at radial extremities broadly rounded.

Trilete suture distinct at apical pole, poorly defined towards spore margin, generally extending to within $4 \mu$ or $5 \mu$ of margin in proximodistal compression; suture margins simple. Proximal pole enclosed by a small, circular, and vaguely defined contact zone with a more granulose surface, darker, but not thicker than remainder of spore coat (pl. 22, figs. 10,11).

Proximal surface smooth; distal surface sparsely ornamented with blunt to pointed tubercular processes, $1.2 \mu-5 \mu$ in diameter and $1.5 \mu-8 \mu$ in length. Tubercles smaller and some more closely set, adjacent to radial extremities. Spore coat ranging in thickness on different specimens from $1 \mu-3 \mu$, thickest distally (pl. 22 , fig. $10)$; deep yellow by transmitted light.

Holotype.-Plate 22, figure 11, from the upper part of the Cuyahoga and Black Hand formation (undifferentiated), locality 7 , maceration 363a, slide 4 .

Discussion.-The spore coat is generally not folded in proximodistal compressions of these spores. However, the holotype specimen shows several short inter- radial marginal folds which accentuate the very slight concavity of the margin.

Spores of this species are fairly large, compared to those of other species of G'ranulatisporites. They compare in size to those of $G$. concavus Kosanke, $G$. convexus Kosanke, G. deltoides (Ibrahim) S. W. \& B., and $G$. grandis Kosanke. Spores of $G$. logani possess a slight darkening at the apex which may be equivalent to the clearly defined contact area of $G$. adnatus.

Ornamentation of spores of $G$. logani is distinct and unlike that of other described species. These spores are larger than and possess more robust and more widely spaced conical tubercles than do spores of $G$. tuberculatus Hoffmeister, Staplin, and Malloy (1955b).

Occurrence.-Spores of this species are common in the upper part of the Cuyahoga and Black Hand formations (undifferentiated) and in the Logan formation, locality 7 (pl.23).

\section{Genus VERRUCOSISPORITES (Ibrahim, 1933) Potonié and Kremp, 1954}

Plate 17 , figure 23 (?): plate 18 , figure 14 ; plate 19 , figure 7

Type species.-Verrucosisporites verrucosus Ibrahim 1933 (p. 24), by designation of Ibrahim.

Description.--Spores trilete, circular to subcircular in equatorial outline. The spore coat is characterized by densely set smooth broad-based warts which are irregularly rounded to bean shaped and may be of differing size (Potonié and Kremp, 1954, p. 137).

Spores of the type species of Verrucosisporites are described by Ibrahim (1933, p. 25) as: more or less oval to circular; coat with densely set tubercles $2 \mu-4 \mu$ long; trilete suture two-thirds length of radius; dimensions of type specimen $65.5 \mu \times 77 \mu$. Ibrahim (1933, pl. 2, fig. 17) clearly depicts the pattern of an inverse reticulum.

Discussion.-In Potonié and Kremp's (1954, p. 143) discussion of Microreticulatisporites (Knox), the authors mention that a negative reticulum (grooves arranged in a network produced by the dense spacing of the irregular tubercles) is characteristic of Verrucosisporites and note that a negative (or inverse) reticulum usually appears much more distinct than a positive fine-meshed reticulum.

Potonié (1954, p. 122-123) questionably refers spores of Verrucosisporites to the Filicales.

Occurrence.-Spores of this genus are Late Tournaisian to early Permian in age in Europe. Hoffmeister, Staplin, and Malloy (1955a) report that North American occurrences are Early Pennsylvanian to Permian in age. From the present study, spores referable to this genus are also found in beds of earliest Mississippian age. 
Verrucosisporites depressus n. sp.

Plate 19, figure 7

Diagnosis.-Spores trilete, lacking preferred compressional orientation, appearing circular in marginal outline, usually without compressional folds; range from $52.5 \mu$ to $72 \mu$ in maximum diameter. Trilete suture distinct, $18 \mu-28 \mu$ in length (about two-thirds of the radius) : suture margins simple. Contact areas indistinguishable. Spore coat $1.3 \mu-2 \mu$ thick, appear's yellow by transmitted light. Ornamentation, present both proximally and distally, consists of very low $(0.6 \mu-1.2 \mu)$ rounded warts, $2 \mu-2.7 \mu$ in diameter, densely spaced; grooves of resulting inverse or negative reticulation less than $1 \mu$ wide.

Holotype.-Plate 19, figure 7, from the basal part of the Sunbury shale, locality 9, maceration 151-3, slide 6 , collection 2-5-3-53.

Discussion.-On some specimens the tubercles, in side view, are so low as to be nearly indistinguishable from preservational irregularities of the spore coat surface. However, the negative reticulum is quite obvious in plan view and is characteristic for spores of this species. One specimen, not included in the description, possesses tubercles as much as $2.7 \mu$ in height and $2.5 \mu-5 \mu$ in diameter but is otherwise similar. These spores are distinguishable from those of the type species by the shorter tubercles.

Occurrence.-Spores are rare, occurring in the Berea sandstone and Sunbury shale at locality 9 and the Sunbury shale at locality 8 (pl. 23).

\section{Verrucosisporites sp.}

Plate 18, figure 14

Description.-Spore trilete, rounded triangular in outline, $51 \mu$ in diameter. Trilete rays distinct, nearly $19 \mu$ long. Spore coat $2.4 \mu$ thick, ornamented proximally and distally with closely spaced parallel sided blunt to pointed tubercles, $3 \mu-3.5 \mu$ long and $2.7 \mu-3.7 \mu$ in diameter.

Occurrence.-Single specimen was found in the Bedfor shale at locality 2 .

\section{Verrucosisporites? sp. A \\ Plate 17 , figure 23}

Description.-Spores trilete, subcircular to rounded triangular in outline, about $45 \mu$ in diameter, appearing dark orange brown by transmitted light. Trilete rays distinct, about $16 \mu$ long on illustrated specimen. Spore coat $2.7 \mu-3.1 \mu$ thick, ornamented with widely spaced tubercles, circular in plan view with rounded ends. Tubercles $3 \mu-3.7 \mu$ long, $6 \mu-7 \mu$ in diameter.

Discussion.-These spores are similar to those of Terrucosisporites triquetrus Ibrahim, 1933, but are more circular in shape and possess more widely spaced tubercles. The spores are also similar to spores of Lophozonotriletes as illustrated by Naumova (1953, fig. 6).

The spore figured has 14 tubercles, some of which are borne on the proximal surface. Because the tubercles are more widely spaced than is usual for spores of this genus, these spores are questionably referred to Vermcosisporites.

Occurrence.-The two measured specimens were found in the Bedford shale at locality 1.

\section{Genus ANAPICULATISPORITES Potonié and Kremp, 1954}

Plate 18, figures 15 (?), 20(?) ; plate 22, figure 12( ?)

Type species.-Anapiculatisporites isselburgensis Potonié and Kremp, 1954 (p. 130), by their designation.

Description.-Spores trilete, $50 \mu-80 \mu$ in diameter (type species) ; originally expanded distally, pyramidal proximally ; rounded triangular to circular in transverse outline.' Trilete rays extend almost to the margin; lips variously differentiated. Proximal surfaces smooth "(as in Schopfites)"; distal surface provided with short conate apiculi or spines which tend to be smaller and more scattered approaching the proximal surface.

Discussion.-These spores differ from those of Schopfites in their original shape and in type of ornamentation. Potonié (1954, p. 122, 123) suggests a questionable affinity with the Filicales.

Occurrence.-Spores of Anapiculatisporites have previously been reported in beds ranging in age from Late Westphalian A to Early Westphalian B. Thus, the occurrences noted here are considerably older.

Anapiculatisporites? retusus n. sp.

Plate 18, figures 15, 20 ; plate 22, figure 12

Diagnosis.-Spores trilete, $57 \mu-90 \mu$ in diameter, originally expanded hemispherically distally and pyramidal proximally; circular (pl. 18, fig. 15) to rounded triangular (pl. 18, fig. 20) in proximal view with no preferred compressional orientation. Trilete rays distinct, about $22 \mu-32 \mu$ long; suture margins simple; spores often broken along suture line. Proximal surface smooth, almost equal in area to the geometrical proximal hemisphere, not delimited by arcuate ridges. Distal surface with numerous basally elongate pointed to blunt apiculi or tubercles, $1.3 \mu-5.2 \mu$ long and $1 \mu-6 \mu$ wide, most densely set and largest at distal pole. Spore coat thick, $1.6 \mu-2.9 \mu$ proximally, $2.5 \mu-4 \mu$ distally; dark yellow by transmitted light.

Holotype.-Plate 18, figure 15, from the Bedford shale, locality 2 , maceration 159 , slide 12 , collection 7-12-6-53-b. 
Discussion.-Folding of the spore coat, mainly along the proximal surface (pl. 22, fig. 12), is rather rare. The shape and size of the distal processes is quite variable on an individual specimen. Usually the processes are smaller and more distinctly acuminate toward the proximal surface; more distal tubercles may be joined at their bases so that the protuberance as a whole appears notched.

These spores possess a completely smooth proximal surface and lack arcuate ridges as do spores of Anapiculatisporites and Schopfites. The original shape is less spherical and the size smaller than that of spores of the latter genus, more like that of Anapiculatisporites spores. The spore coat thickness is much the same as on spores of Schopfites. The distal omamentation seems more acuminate and less densely distributed than on spores of the latter genus but less consistently apiculate than on spores of Anapiculatisporites. The distribution and size differentiation of processes from equator to distal pole is similar to that on spores of both genera. However, these Lower Mississippian spores lack labial differentiation.

In view of the time interval between the occurrence of this Lower Mississippian species and that of Schopfites and Anapiculatisporites, the relationship suggested here may be questionable. In general the morphologic character of the spores is more like that described for Anapiculatisporites.

Occurrence.-Spores present, not abundant, in the Bedford shale at localities 1, 2, and 6, the Berea sandstone at locality 5 , the Sunbury shale and lower part of the Cuyahoga formation at locality 8, and the Cuyahoga and Black Hand formations (undifferentiated) at locality 7 (pl. 23).

\section{Class GYMNOSPERMAE \\ Order CORDAITALES \\ Family PITYEACEAE}

Genus CALLIXYION Zalessky, 1911

Plate 19, figure 12

Type species.-Callixylon trifilievi (Zalessky) Zalessky, 1911.

Description.-Secondary wood of pycnoxylic type, with fusiform tracheids and narrow rays; tracheids with multiseriate bordered pits associated in groups on the radial walls; pit groups separated from other pit groups on the same tracheid by areas free of pits, and alined with similar pit groups of adjacent tracheids in the same radial file.

Discussion.-Occurrence of the radial alinement of the gymnospermous type of pit groups is regarded as adequate evidence for the recognition of this genus. No other examples that closely duplicate this phenom- enon are known to occur in plants living or fossil. (See Kräusel and Weyland, 1937, p. 351-352; Arnold, $19+7$, p. 283 ; Hoskins and Cross, 1951, p. 685-686.)

Occurrence.-Although Callixylon has been traditionally regarded as an Upper Devonian plant, Hoskins and Cross (1951) have also reported its occurrence in the Kinderhook series of Illinois and the Lower Mississippian of Kentucky.

\section{Callixylon sp.}

Plate 19, figure 12

Description.-'This identification is based on a fragment of semifusinized secondary wood that shows the radial walls of parts of two tracheids and a few ray cells; bordered pits with crossed apertures are aggregated into groups of 10 to 18 pits and the pit groups of adjacent tracheids are in regular radial alinement.

Discussion.-Cross and Hoskins (1951) point out that study of primary wood is desirable for specific discrimination; it would also be desirable to have a more ample specimen of secondary wood. However, it appears that a generic determination can be as well supported by the tiny fragment reported here as it could be from a much larger specimen.

According to Arnold (1947), the Pityeaceae are known in the Devonian and lower Carboniferous and are classified under the Cordaitales on the basis of structural resemblances of the woods. One species, Callixylon newberryi, is one of the best known of all black shale plant fossils, occurring in the Chattanooga shale in Tennessee and Kentucky, the New Albany shale in Kentucky, and the Ohio shale of Ohio and Kentucky. This species seems not to be reliably identified in beds younger than Late Devonian. The redescription of Pitys brownii Read, found in the nodule zone of the Falling Run member of the Sanderson formation of Campbell (1946) near Junction City, Ky., as Callixylon brownii (Read) Hoskins and Cross (1951) has the effect of extending the range of the genus Callixylon into the Lower Mississippian if the nodule zone is Mississippian as it appears to be (Campbell, 1946). Cross and Hoskins (1951) also mention the discovery of Callixylon specimens from the type area of the Kinderhook series near Kinderhook, Ill.

The fragment shown on plate 19 , figure 12 , can be regarded as further evidence of the occurrence of Callixylon in strata of Early Mississippian age. The pit groups seem to closely resemble some of those of the undescribed species of $C$ allixylon illustrated by Hoskins and Cross (1951, p. 707) from Crab Orchard, Ky.

Occurrence.-Fragment found in upper part of the Bedford shale, 6 feet below the Berea sandstone, at locality 3. 
Order and Family UNCERTAIN

Genus SPERMatites Miner, 1935

Plate 21, figure 3

Type species.-Spermatites elongatus Miner, 1935 (p. 597).

Description.-Small hollow structures characteristic of construction in seeds, varying in shape and size.

Discussion.-The genus was established by Miner for purposes of convenience in classifying seedlike structures obtained by maceration. Seminal integuments of gymnosperms often have cuticular membranes and other structures of significance that merit study. By reference to this taxon, these results may be systematically reported. The forms treated here differ from those described by Miner (1935) and by Arnold (1948b), but they are evidently fossils of the same general character.

Occurrence.-Fossils referable to Spermatites probably indicate the presence of seed-bearing plants; they should be common in post-Mississippian rocks. The presence of seeds in the Devonian has not yet been confirmed. Early Mississippian occurrences, therefore, assume special interest.

\section{Spermatites sp.}

Plate 21, figure 3

Description.-Cuticular envelope (integumental?) about $2.2 \mathrm{~mm}$ long and $0.9 \mathrm{~mm}$ broad, almost elliptical in outline in compression. Original symmetry uncertain. Epidermal cell pattern more or less isodiametric (about $20 \mu-25 \mu$ ), polygonal, indistinct in part but apparently uniform. Cell wall "muri" about $5.5 \mu$ thick. External (outer wall) membrane as much as $8 \mu$ thick; internal membranes indistinct or absent.

Discussion.-Two similar forms were found, one of which is shown on plate 21, figure 3. The external membrane, as illustrated, is less than $5 \mu$ thick. It is about $6 \mu-8 \mu$ thick on the other example.

These forms are similar in general aspect to those Arnold (1948b) described as Spermatites reticulatus from the Pennsylvanian of southern Michigan. The specimens from Ohio differ in having smaller cells less prominently defined and in the absence of a conical cap, although this may at one time have been present.

A species is not named because more abundant and better preserved material is likely to be found. The present specimens may be harbingers of additional knowledge about seminal evolution during Early Mississippian time when this was a new manner of dissemination.

Occurrence.-The two similar specimens were found in the basal part of the Bedford shale at locality 1 and just below the Sagamore siltstone member of the Bedford shale at locality 2 . Similar but more poorly preserved specimens also are present in the Berea sandstone at locality 5 .

\section{Class, Order and Family UNCERTAIN}

\section{UNIDENTIFIED VASCULAR FRAGMENTS}

Plate 19, figure 13

Discussion.-During this investigation many samples of both Late Devonian and Early Mississippian age were noted to contain, in addition to spores, abundant fragmental plant remains that show definable characteristics but are as yet unidentifiable for want of study. The most common of these consist of splinters of vascular tissue preserved as fusain or semifusain. A concentrated study of these fragments might add valuable information beyond that supplied by other microfossils. The fragments are derived from vegetative rather than reproductive phases of the life cycle of the plants represented and offer an additional source of information about plant life of the period.

The fragment illustrated on plate 19, figure 13, shows numerous bordered pits in parallel continuous series. As such it affords a positive indication of the presence of a fairly advanced type of plant, probably allied within the Pteropsida.

Occurrence.-This type of vascular tissue is a conspicuous and abundant element of the plant microfossil assemblage in the Berea sandstone at locality 5.

\section{Subdivision UNCERTAIN}

Genus LAEVIGATOSPORITES (Ibrahim, 1933) Schopf, Wilson, and Bentall, 1944

Plate 15, figures $1,8,8 \mathrm{a}, 9,10$

Type species.-Laevigatosporites vulgaris (Ibrahim) Ibrahim, 1933 (p. 39), by designation of Ibrahim.

Description.-Spores monolete, bilateral, from $14 \mu-$ $150 \mu$ in length, reniform to oval in lateral-longitudinal view, cordate to round in lateral-transverse view and somewhat elliptical in proximopolar view. Spore coat generally $1 \mu-3.5 \mu$ thick (Kosanke, 1950), smooth to variously ornamented.

Discussion.-Schopf, Wilson, and Bentall point out that the monolete bilateral spores could conceivably pertain to at least three distinct contemporaneous orders of Paleozoic plants, and they mention members of the Calamitales and Filicales or Cycadofilicales. Andrews and Mamay (1951) later showed that this spore type also is represented in one species of Bowmanites, a genus that is reliably referred to the Sphenophyllales. The occurrence of monolete spores in Psilotum, Isoetes (microspores) and various genera 
of ferns in the modern flora indicates that the monolete tetrad has originated anew in many groups of plants and is not, by itself, likely to be a reliable guide to botanical affinity or age determination. However, abundantly represented species, identified on the basis of several correlated characters, are of value as ecological indicators. In such instances the species may also have a corresponding value in establishing stratigraphic relationships. The genus represents a taxon of convenience, but forms that are abundant and appropriate for specific determination in a given region should, none the less, be interpretable with botanical consistency.

Potonié and Kremp (1954) have separated several of the monolete types of spores into different genera which would ordinarily be referred to Laevigatosporites in the sense of Schopf, Wilson, and Bentall. In some instances this may prove advantageous, but it does not seem as appropriate for classification of the present material, and the genus is identified here in its broader interpretation.

Occurrence.-Spores of this genus are common in Pennsylvanian and Permian rocks as well as in rocks of Mesozoic and Cenozoic age. Berry (1937), Schemel (1950), and Hoffmeister, Staplin, and Malloy (1955b) report spores of Laevigatosporites from Mississippian rocks in this country. The latter authors, however, note that the absence or very rare occurrence of monolete spores is characteristic of Mississippian rocks. In another paper (1955a, p. 10) they also mention the occurrence of spherical monolete spores, a monolete megaspore, and a bean-shaped monolete spore in Upper Devonian shales of Canada. Some of these are probably referable to Laevigatosporites.

Smooth monolete spores were found in this investigation in the Berea sandstone of Early Mississippian age at locality 5 and in the Bedford shale at locality 1. One ornamented example (pl. 15, fig. 8, 8a) was found in the Bedford shale (pl. 23).

\section{Laevigatosporites spp.}

Plate 15, figures $1,8,8 a, 9,10$

Of the 6 specimens noted in the Berea sandstone, 3, like the one shown on plate 15 , figure 1 , have spore coats less than $2 \mu$ thick. Two are somewhat oval and the smallest $(46 \mu \times 46 \mu)$ is circular in outline. Of the 3 remaining, 2 are shown on plate 15, figures 9 and 10 ; these are oval to nearly circular in outline and show no preferred compressional plane. These spores are smooth, bright yellow, and thick walled $(3 \mu-3.5 \mu)$. None of the six monolete spores possess lips. Mono- lete spores similar to those found in the Berea sandstone were also noted in the Bedford shale at locality 1.

The monolete spore, shown at different focal levels by figures 8 and $8 \mathrm{a}$ on plate 15 , is a highly ornamented unique example from the Bedford shale.

Spores of Laevigatosporites are scarce in this material, but it does not seem likely that they are contaminants. Their occurrence is mainly of interest in supplementing the record of monolete spores of plants in Early Mississippian time.

\section{Genus GRANDISPORA Hoffmeister, Staplin, and Malloy, 1955}

Plate 16, figure 12

Type species.-Grandispora spinosa by designation of Hoffmeister, Staplin, and Malloy, 1955b (p. 388).

Description.-Hoftmeister, Staplin, and Malloy (1955b) describe spores of this genus as follows,

*** Spores radial, trilete ; central body enclosed by a bladder. both subcircular; central body levigate(?); possible punctate or granulose; bladder wall punctate to granulose, possibly levigate, with prominent scattered spines; trilete rays weak, simple, apparently extend to edge of central body; central body wall only slightly thicker than the bladder wall, translucent.

Discussion.-The authors remark that the spinose bladder distinguishes spores of this genus from Endosporites. The affinity of these spores is apparently unknown. Whether or not the possession of bladder spines by these spores is evidence of origin unallied to that of spores of Endosporites is in question.

Occurrence.-Spores of the type species occur in the Hardinsburg sandstone of Late Mississippian age. Hoffmeister, Staplin, and Malloy (1955a) report the occurrence of similar spores in the Upper Devonian of western Canada. However, in a later correction of this paper, Hoffmeister and Staplin (1955) note that the genus is limited to the Upper Mississippian.

\section{Grandispora sp.}

Plate 16, figure 12

Description.-Spore, $88 \mu$ in diameter, has trilete central body, $56 \mu$ in diameter, enclosed in a spinose bladder not connected to spore body distally. Trilete rays weak but appearing to extend as folds for a short distance out onto bladder. Spore body coat $1.8 \mu$ thick, that of bladder somewhat thinner. Bladder spinules about $2 \mu$ in diameter and $3 \mu$ in length.

Discussion.-This specimen, from the Chagrin shale, locality 6 , is somewhat smaller than spores of the type species and has smaller bladder spinules. Otherwise, details of spore morphology are quite similar. 
Genus CYRTOSPORA n. gen.

Plate 22, figures 18,19 , and 20

Type species.-Cyrtospora clavigera n. sp. (cf. pl. 22 , figs. 18, 19, 20) from Bedford shale at localities 1 and 6 , the Berea sandstone at locality 5, the Sunbury shale and the Cuyahoga and Black Hand formations (undifferentiated) at locality 7, and the Cuyahoga formation at locality 8 .

Diagnosis.--Spores trilete, asymmetrically subprolate, proximal end flattened, distal end extended, subcircular to subtriangular in transverse outline, about $40 \mu-50 \mu$ long and $30 \mu-50 \mu$ broad.

Trilete suture distinct, extending nearly to equator; suture margins simple; contact surfaces smooth and not defined equatorially.

Distal surface smooth, with a large irregular intumescent or glebous mass and tubercles. Distal mass consists of spore coat material as much as $27 \mu$ thick and $20 \mu-45 \mu$ broad, variously situated as an integral part of the distal wall. Tubercles irregularly scattered, short, truncated, mostly $3 \mu-5 \mu$ in height and nearly as broad, some grown together basally on the glebous area of the coat.

Proximal wall $1 \mu-2.5 \mu$ thick near the pole; distal wall thicker, becomes very thick and dense in tumid areas. Spores red to brown and nearly opaque in thickest parts by transmitted light.

Discussion.--The distal thickening of these spores is generally similar to the crescentic coat thickening of spores of Torispora securis Balme (1952). This thickening is asymmetrically located in relation to the monolete suture. Balme (1952) stated that thickening probably took place after separation from the tetrad, but it seems more probable that the distal spore coat thickening of Cyrtospora, at least, was initiated within the spore mother cell.

Spores of the Cyrtospora type have not been associated with any fertile organs; so there is no evidence of their botanical relationship. Since the spores are so distinctive, eventual proof of their relationship to a more or less distinctive type of land plants can be expected.

Occurrence.-Cyrtospora has only been identified in rocks of Early Mississippian age in Ohio. They are so abundant in these rocks that it may only be a matter of time before they are reported elsewhere.

\section{Cyrtospora clavigera n. sp.}

Plate 22, figures 18,19 , and 20

Diagnosis.-Spores trilete, originally asymmetrically subprolate (distally extended), usually compressed obliquely or laterally; ranging from $31 \mu$ to $49 \mu$ (usually more than $38 \mu$ ) in transverse diameter, from $42 \mu-59 \mu$ in axial length including distal ornamentation (30 specimens measured). Haptotypic structures, ornamentation, and spore coat characteristics are as given for the genus.

Holotype.-Plate 22, figure 19, from well cuttings of the Cuyahoga and Black Hand formations (undifferentiated), locality 7 , maceration 366 , slide 3 .

Discussion.- The distal ornamentation is quite variable. The tubercles are blunt or rounded, usually slightly larger terminally, some terminations partite. These protuberances are most densely concentrated on the distal thickening. The glebous mass can be accounted for, in part, by fusion of the bases of tubercles. The specimen shown on plate 22 , figure 20 , although abraded, shows the distal thickening as a rough solid mass.

Occurrence.-Spores of this species are abundant in the Cuyahoga and Black Hand formations (undifferentiated) at locality 7. A few specimens are also present in the Bedford shale at localities 1 and 6 , the Berea sandstone at locality 5, the Sunbury shale at locality 7 , and in the lower part of the Cuyahoga formation at locality 8 (pl. 23).

\section{Genus CANTHOSPORA n. gen.}

Plate 15 , figures $2,3,4,5,6,7,7 \mathrm{a}, 7 \mathrm{~b}$; plate 19 , figure $2($ ?) ; text figures $8 \mathrm{~A}, 8 \mathrm{~B}, 9 \mathrm{~A}, 9 \mathrm{~B}$

Type species.-Canthospora patula n. sp. (cf. figs. $8 \mathrm{~A} 8 \mathrm{~B}$; pl. 15, figs. 4, 6) from the Bedford shale at localities $1,3,6,8$, and 9 and the Berea sandstone at locality 9.

Diagnosis.-Spores trilete, with a prominent equatorial girdle, asymmetrically oblate lenticular, flattened proximally, more expanded distally, circular to subcircular in transverse outline, usually compressed in transverse plane, relatively large, $80 \mu-175 \mu$ in overall diameter; body cavity $65 \mu-150 \mu$ in diameter (usually $70 \mu-125 \mu)$.

Trilete suture distinct, confined within the prominent body cavity outline and usually extending for $2 / 3$ to $3 / 4$ of its radius; suture margins simple or slightly elevated as thin lips; contact areas smooth, defined only with reference to the rays.

Equatorial region thickened and extended into a broad solid girdle or cingulum, with rounded margin, slightly lobate, irregular, and a tendency to appear concentrically striated (fig. $8 \mathrm{~A}$, pl. 15, fig. 6). Proximal internal margin of cingular rim usually defined clearly within the outline of the body cavity; cingulum overlaps cavity proximally more than distally.

Distal surface smooth, with small tubercles or a central thickening (pl. 15, figs. 3, 7, 7a) on some spores. 
Proximal and distal coat $1.5 \mu-3 \mu$ thick; equatorial girdle much thicker, as much as $40 \mu$, with inner and outer layers differing slightly in density, outer layer highly translucent in relation to its thickness; yellow to red to brownish red by transmitted light.

Discussion.-Extreme equatorial thickening in $C$ anthospora invites comparsion with other trilete spores that possess a cingulum, or a thickened equatorial girdle. These are included in generic groups ${ }^{7}$ listed below:

1. Densosporites (Berry, 1937), emend. S. W. \& B. (1944), s. s. (smooth) (=Zonales-sporites [part] Loose, 1934; = Anulatisporites Potonié and Kremp, 1954)

2. "Spinose Densosporites," cingulate spores that some authors have segregated but to which, in that case, the name "Densosporites" cannot be correctly applied. (See p. 48.)

3. Murospora Somers, 1952 (= Simozonotriletes Potonié and Kremp, 1954)

4. Knoxisporites Potonié and Kremp, 1954

Spores of Canthospora would show a dumbbell shape, like the other groups listed, when compressed and observed in vertical section (cf. pl. 1, fig. $9 \mathrm{~b}$, of Schopf, Wilson, and Bentall, 1944). The equatorial girdle tends to overlap the body cavity in Densosporites more than in Canthospora and the girdle may also be flattened and extended to simulate a flange, especially among spinose types of Densosporites (cf. pl. 13, fig. 56), Anulatisporites of Potonié and Kremp, 1954).

Thus the Densosporites group, taken in a broad sense, includes more extremes of girdle elaboration than is known for Canthospora. The range in size is different, however: Canthospora is considerably larger and is subcircular rather than subtriangular; the distal side is more expanded as evidenced by concentric folds; and the spore coat is composed of layers of variably translucent types of material. The principal and abundant representation of Densosporites is in beds younger than those containing Canthospora.

Murospora Somers is based on spores that are subtriangular and smaller, and thus readily distinguishable from Canthospora. However, the general proportions of the equatorial girdle are similar, and older species

\footnotetext{
${ }^{7}$ Dates of references validating the names are given in the list. In these groups some confusion has arisen because of duplication of names. Thus, although Anulatisporites was mentioned in a footnote by Loose in 1934, he did not validate or adopt the name. Likewise, Simozonotriletes was used, but not validated, by Naumova in 1939. Apparently no description or reference to type material was available until Potonié and Kremp (1954) supplied them. They cite $S$. intortus as the type species described by Ulrich Horst in his unpublished dissertation (Horst, Technische Hochschule, Berlin, 1943). Question therefore remains about this genus until its type species is effectively published. A different name (Murospora) has been validly established for the same group (Somers, 1952).
}

of the genus (Tournaisian), usually assigned to Simozonotriletes, are larger, approaching the lower range of spores assigned to Canthospora.

The annular murus found in spores of Knoxisporites Potonie and Kremp, may be compared with the equatorial girdle of Canthospora. The resemblance is especially noteworthy in illustrations of Knoxisporites from beds of Chester age, given by Hoffmeister, Staplin, and Malloy (1955a, 1955b). The distal muri serve readily as a means of differentiation, but resemblance is close enough to consider the possibilities of phyletic relationship. In this connection the central distal boss, shown on plate 15 , figures $7,7 \mathrm{a}$, and $7 \mathrm{~b}$, is of great interest because, although this is a unique specimen, it shows that a type of distal thickening, different in kind but on occasion just as extreme as in Knoxisporites, was represented in Canthospora.

Spores of Archaeozonotriletes variabilis Naumova (1953) possess a wide irregular equatorial girdle somewhat reminiscent of spores of Canthospora patuia. However, the spores Naumova describes are smaller and details necessary for critical comparison are lacking in her descriptions.

At present, no evidence as to affinity can be suggested for Canthospora. It is presumed to represent a group of land plants belonging to one of the vascular cryptogams (Pteropsida [part], Sphenopsida or Lycopsida.)

Occurrence.-Spores referred to this genus were found in the upper part of the Ohio shale or Chagrin shale, in the Bedford shale, in the Berea sandstone and in the lower part of the Cuyahoga formation (pl. 23). Spores of the genus, not referable to the two described species, are also present in the Cuyahoga formation at locality 8. They were not found in the Cuyahoga and Black Hand formations (undifferentiated) or in the overlying Logan formation at locality 7 .

The most common occurrence is in the Bedford shale, but specimens are not abundant.

Canthospora patula n. sp.

Plate 15, figures 4,6 ; text figures $8 \mathrm{~A}, 8 \mathrm{~B}$

Diagnosis.-Spores trilete, with prominent equatorial girdle, oblate lenticular, flattened proximally, distally more extended (fig. 8B), circular to subcircular in transverse outline, $90 \mu-175 \mu$ in overall diameter; spore cavity prominent, $65 \mu-115 \mu$ in diameter (16 specimens measured).

Trilete rays straight, $25 \mu-45 \mu$ long, fading out radially just inside the inner line of the cingulum; lips membranous, as much as $6.7 \mu$ in height at pole and declining radially; contact areas defined only with reference to the rays.

Equatorial girdle $11 \mu-39 \mu$ thick (from edge of spore 
cavity), double layered, inner layer (endoexosporium?) slightly darker; outer layer of more variable thickness, restricted to equatorial girdle (cf. fig. 8B). Spore coat simple (single layer) in central proximal and distal area, $2 \mu-3 \mu$ thick; some irregularly thickened in central distal area. Surface smooth, yellow to brown by transmitted light, dark and glossy by reflected light.

Holotype.-Plate 15, figure 6, from the Bedford shale, locality 1 , maceration $40 \mathrm{C}$, slide 27 , collection 4-11-1-52.

Discussion.-The outer layer of the equatorial girdle is somewhat variable and difficult to interpret in the compressed specimens that are available. It appears to represent a deposit of lower density material that supplements the already prominent girdle thickening of the spore coat. In some sectors of individual spores the outer and inner layers seem to merge, although elsewhere the boundary is distinctly marked by refractive lines. The inner line of the cingulum apparently marks the proximal limit of this outer layer of material as indicated in the reconstructed cross section (fig. $8 \mathrm{~B})$. The inner layer is usually more uniform in thickness.

Evidence for this interpretation is chiefly to be gained from torn or folded specimens, but these are not

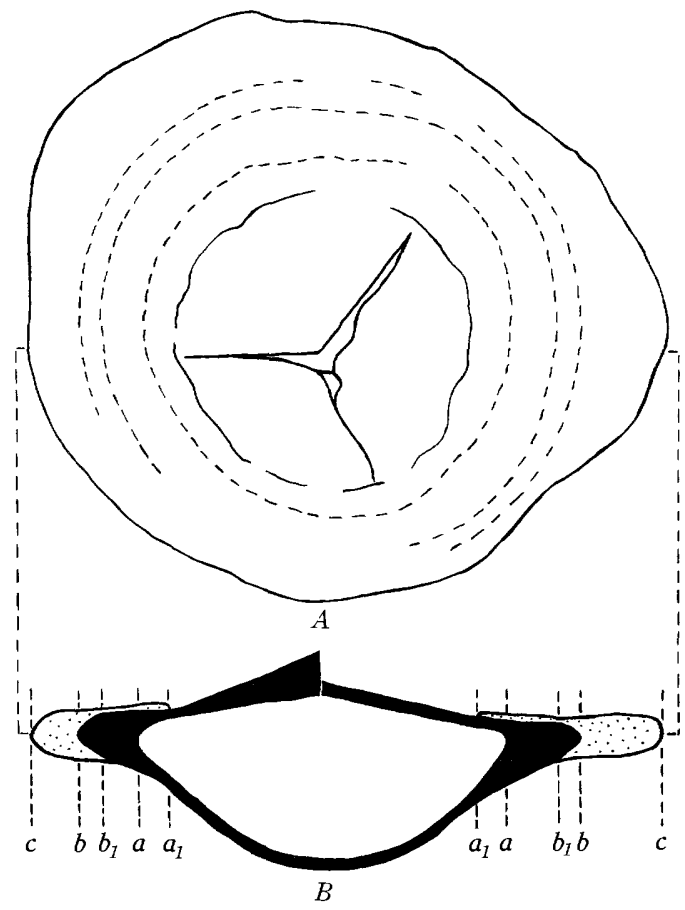

Figure 8.- $A$, diagrammatic proximal view of a spore of Canthospora patula n. sp. Dashed lines indicate internal features. $B$, Diagrammatic axial section of same spore. $a_{1}$ indicates overlap of rim, $a$ indicates margin of body cavity, $b_{1}-b$ indicates band of different refraction caused by rounded margin of inner spore coat layer, $c$ indicates outer margin of rim. $\times 500$. abundant, relatively good preservation being the rule. Folds generally involve the distal wall, follow a more or less concentric pattern, and do not cross the rim.

These spores seem similar to the specimen illustrated by Luber and Waltz (1938, pl. 5, fig. 57) as Azonotriletes indecorus Luber. The size given by Luber and Waltz $(1938$, p. 23$)$ as $150 \mu-200 \mu$ is slightly greater than of most spores of Canthospora patula. The forms may be closely related but critical details of morphology are lacking in Luber's description and no type was designated by him. Spores of Azonotriletes indecorus are found in the Karaganda basin in deposits of Viséan age.

Luber and Waltz (1938, p. 42) state that spores of Lower Carboniferous coals of the Karaganda basin differ greatly from those of other Lower Carboniferous coals in the European part of the U.S.S.R. These differences lead them to postulate the existence of a peculiar provincial flora in the Karaganda region that differs from the European and is characterized by strict endemism. The discovery of a possibly closely related American species is of considerable interest.

Occurrence.-This species is present in the Bedford shale at localities 1-3, 6, and 8, and in the Bedford shale and Berea sandstone at locality 9. Although never very abundant, the spores were found most frequently at locality 1 (pl. 23).

\section{Canthospora cracens $n$. sp.}

Plate 15, figures 2, 3 ; text figures $9 \mathrm{~A}, 9 \mathrm{~B}$

Diagnosis.-Spores trilete, similar to spores of $\boldsymbol{C}$. patula in general form; girdle less prominent than on spores of that species; spores more distorted by compressional folding on that account. At least one broad fold generally present (pl. 15, fig. 2). Spore cavity prominent, $70 \mu-145 \mu$ (mostly $75 \mu-125 \mu$ ) in diameter; spores $80 \mu-170 \mu$ in overall diameter (12 specimens measured).

Trilete rays straight and distinct, usually $40 \mu-60 \mu$ long or about $1 / 3^{-2} / 5$ of the overall diameter, extending nearly to inner cingulum margin. Suture margins simple or very slightly elevated at the pole.

Equatorial girdle $6 \mu-13 \mu$ thick, double layered; inner layer $3 \mu-6 \mu$ thick or about half as thick as in $C$. patula, distinguished from outer layer by refractive differences; outer marginal layer relatively uniform (cf. fig. 9A, 9B).

Spore coat single layered in central proximal area, $1.5 \mu-3 \mu$ thick, similar distally except for an occasional irregular central thickening ( $\mathrm{pl} .15$, fig. 3). Surface smooth; spores yellow to orange, equatorial region darker by transmitted light. 
Holotype.-Plate 15, figure 3, from the Bedford shale, locality 1 , maceration $40 \mathrm{~B}$, slide 13 , collection 4-11-1-52.

Discussion.-Differences of shape and greater uniformity of the narrower equatorial girdle distinguish $C$. cracens from the type species, although the two species are generally similar in size. More common folds are of assistance in interpreting the girdle in $C$. cracens. Examples incompletely compressed because of mineral fillings are of further assistance in understanding the equatorial structure which is diagrammatically shown in reconstructed cross section in figure $9 B$.

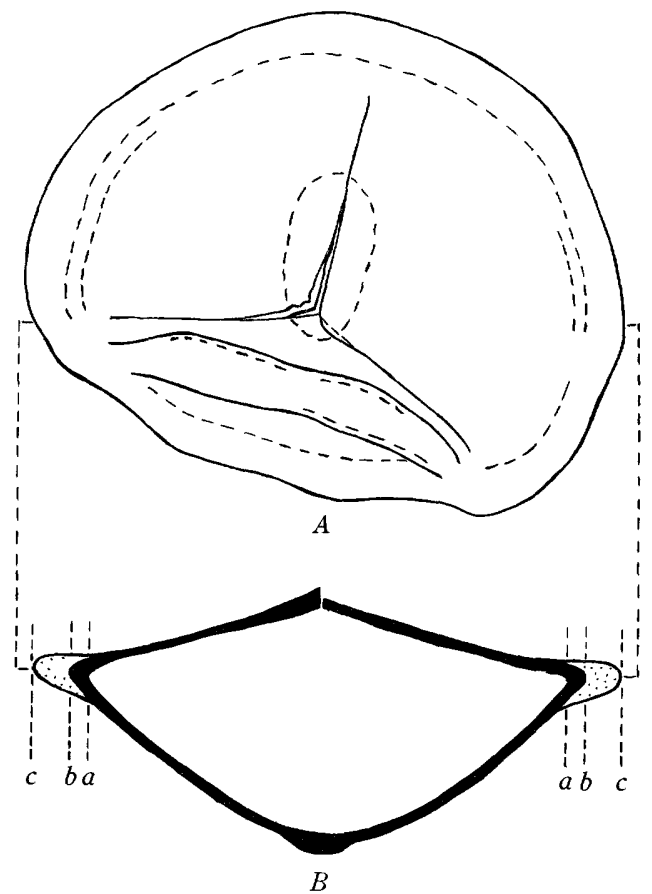

Figure 9.- $A$, Diagrammatic proximal view of a spore of Canthospora cracens n. sp. Dashed lines indicate internal and distal features. $B$, Diagrammatic axial section of same spore; $a$ indicates margin of body cavity, $a-b$ indicates band of different refraction caused by rounded margin of inner spore coat layer, $c$ indicates outer margin of rim. $\times 500$.

Occurrence.-Spores of this species, never numerically abundant, were identified in the Chagrin shale at localities 6 and 8 ; Cleveland member of Ohio shale at locality 6 ; Bedford shale at localities 1 and 2 ; Berea sandstone at locality 5 ; and in the lower part of the Cuyahoga formation at locality 8 (pl. 23). The species appears to be longer ranging than $C$. patula.

\section{Canthospora spp.}

Plate 15, figures 5, 7, 7a, 7b

The specimen shown on plate 15 , figure 5, about $100 \mu$ in diameter, is the only one known that is of this type. Its appearance is apparently due to unusual folding which causes the cingulum to seem deceptively wide. Actually the cingulum is only $9 \mu$ thick in optical section, much the same as that in $C$. cracens. Trilete rays are about $31 \mu$ long, faint terminally, with simple suture margins. The distal coat bears no thickened area, but is ornamented with small tubercles adjacent to the rim, like the spore shown on plate 15 , figure 7a.

Figures $7,7 \mathrm{a}$, and $7 \mathrm{~b}$ on plate 15 represent another unique specimen at different levels of focus. It has a wide equatorial girdle somewhat similar to, but more regular than, that of $C$. patula. The distal coat is thin, folded parallel to the cingulum, and has an exceptionally large, almost bulbous, central distal thickening. The distal surface bears small tubercles as much as $4 \mu$ in diameter. Trilete rays are distinct and long (pl. 15, fig. $7 \mathrm{~b}$ ) with simple suture margins. If it were not for the presence of the small distal tubercles, this specimen would probably have been referred to C. patula.

These examples seem distinctive in detail, but study of more material will be required to evaluate them.

\section{Canthospora? sp.}

Plate 19, figure 2

This specimen shows the same kind of marginal spore coat differentiation and thickening and is about the same size as spores of Canthospora. However, the equatorial girdle and spore cavity are subtriangular and lips prominently developed. The distal spore coat possesses several irregular thickenings. This is the only specimen of the kind that has been observed and more material is required for identification.

Genus CoNVoLUTISP0RA Hoffmeister, Staplin, and Malloy, 1955

Plate 17, figures 20,21, 22, 24, 25, 26

Type species.-Convolutispora florida Hoffmeister, Staplin, and Malloy, 1955b (p. 384), by their designation.

Description.-Hoffmeister, Staplin, and Malloy (1955b, p. 384) describe spores of this genus as:

* * * radial, trilete; circular to subcircular, probable original spherical shape indicated by lack of orientation preference; ornamentation closely packed overlapping anastomosing vermiculate or obervermiculate ridge-like processes, often causing a convoluted or coarsely reticulate-punctate appearance: trilete rays short, usually simple, but may have distinct lips, often obscured by the overlapping ridges: spore coat thick, lacking conspicuous folding, translucent; diameter 40-150 microns.

Discussion.-Spores assigned to this genus have unusual ornamentation. The basic anastomosing pattern of ridges is complicated further by nodes or tubercles in forms described below. These often appear 
more distinctive than the underlying ridges that they rest on. Spores of Convolutispora lack haptotypic features other than the trilete suture and the suture lines often are obscured by the heavy ornamentation. Probably the length of rays is specifically variable as well as often obscure. The ornamentation is evidently almost entirely emphytic, deposited after breakdown of the spore mother cell and separation of tetrads within the sporangium.

Such spores are distinctive and far ranging, having been recognized in Lower Carboniferous deposits in Russia as well as in the Mississippian of the United States. Under these circumstances it would seem reasonable to expect they would be recognized within sporangia of plants known as megafossils. Information of this sort is needed to provide evidence of botanical relationship. If fertile sporangia related to Convolutispora ever are discovered, the spores still may not bear a completely characteristic ornamentation. The heavy mature ornamentation in Convolutispora probably was completed just before sporangial dehiscence and spores with an immature coat are more likely to be found in fossil fructifications. For the present, affinity of Convolutispora is unknown, and it is presumed to represent one of the terrestrial vascular cryptogams.

Two species from Lower Carboniferous (Tournaisian) deposits in central Asia, described under the name Azonotriletes by Luber and Waltz, have been assigned to Convolutispora by Hoffmeister, Staplin, and Malloy (1955) b). The forms described below are similar in age but specifically distinct from the Asiatic species. Material described by Hoffmeister, Staplin, and Malloy is from the Hardinsburg sandstone of Chester age.

Occurrence.-Wide spread, but nowhere present in abundance. Characteristic of beds of Mississippian age.

Convolutispora tuberosa n. sp.

Plate 17 , figures 20,21 , and 22

Diagnosis.-Spores trilete, originally subspherical, compressions lacking preferred orientation, outline subcircular, $65 \mu-105 \mu$ in diameter including ornamentation.

Trilete rays obscured by ornamentation, some appear irregular, nearly equal to spore radius in length.

Ornamentation prominent, uniformly developed, consisting of numerous blunt tubercles or tuberculate ridges, $5 \mu-12 \mu$ high, as much as $8 \mu$ broad and $5 \mu-22 \mu$ long, arranged in a somewhat linear, irregularly anastomosing pattern.

Spore coat dense, $2 \mu-3 \mu$ thick, red to brown by transmitted light.
Holotype.-Plate 17, figure 21, from the Bedford shale, locality 1 , maceration 162 , slide 8 , collection $17-12-6-53$.

Discussion.-Elongate tubercles may occur at points where ornamental ridges merge. Lines of tubercles extend parallel to the trilete suture and apparently do not cross, but the ornamentation crowds the suture so closely that critical observation may often be impossible.

The tubercular ornamentation is coarser on Convolutispora tuberosa than it is on any specimens from the Hardinsburg sandstone illustrated by Hoffmeister, Staplin, and Malloy (1955b), although it seems to follow the same basic pattern. C. tuberosa most closely resembles $C$. florida (especially pl. 38, fig. 6, in Hoffmeister, Staplin, and Malloy), the type species, but, in addition to differences in ornamentation, it is considerably larger.

Small specimens of $C$.tuberosa superficially resemble Reticulatisporites crassus, but lines of ornamental tubercles cover the surface of the former and open reticula are lacking. Tubereles of $C$. tuberosa also differ greatly from the slight extensions formed by the intersection of muri in Reticulatisporites.

Occurrence.--Spores of this species are rare, but present in the Bedford shale of localities 1 and 2 and in the Sunbury shale and lower part of the Cuyahoga formation at locality 8 (pl. 23).

\section{Convolutispora sp. A}

Plate 17, figures 24, 25

Description.-Spores trilete, originally subspherical, compressions lacking preferred orientation, outline subcircular, $74 \mu-90 \mu$ in diameter.

Trilete rays straight, about two-thirds spore radius in length, obscure on some spores.

Ornamentation prominent, uniformly developed, consists of a partly anastomosing maze of sinuous verrucose ridges; ranges from $3 \mu$ to $7 \mu$ high and about $4 \mu$ wide; ridges lack orientation except for conformity with sutures.

Spore coat dense (because of ornamentation), about $2 \mu$ thick, usually brown by transmitted light.

Discussion.-The verrucose ridges diminish in width outwards and verrucose prominences come to a rounded moderately acute point (pl. 17, fig. 25). The ridges do not cross the suture, but they are usually crowded closely and parallel the suture lines. The proximal pole is almost in the center of figure 24 on plate 17 ; in figure 25 it is near the margin of the spore at the lower right.

These forms, which occur infrequently in the Lower Mississippian beds studied, most closely resemble spores from the Hardinsburg sandstone described as $C$. mel- 
lita by Hoffmeister, Staplin, and Malloy (1955b). The pattern of ornamentation seems a little sharper and more prominent and it seems wiser to withhold identification until more material is studied.

The texture of ornamentation appenrs definitely coarser than that of either C. tuberculata (Waltz) Hoffmeister, Staplin, and Malloy or $C$. variotuberculata (Luber) Hoffmeister, Staplin, and Malloy, as presented in illustrations of Luber and Waltz in 1938.

Occurrence.-The specimens illustrated are from the Bedford shale at locality 1 and the lower part of the Cuyahoga formation at locality 8. Other spores of this type have been observed in the Bedford shale at locality 2 and the Sunbury shale at localities 8 and 9 . The spores are an apparently rare but consistent element of the assemblages in the Bedford and Sunbury shales and the lower part of the Cuyahoga formation.

Convolutispora sp.

Plate 17, figure 26

Discussion.-A single specimen that seems distinct from any forms previously described is illustrated on plate 17, figure 26. The ornamentation of broadly tuberculate, partly anastomosing ridges is coarser than that of described species of Convolutispora. The specimen is $120 \mu$ in diameter. This seems relatively extreme, and more material should be studied in order to determine whether these characteristics are relatively consistent or whether this individual merely represents a sport.

Occurrence.-This specimen is from the Bedford shale at locality 2 .

Genus RADFORTHIA n, gen.

Plate 16, figures 15, 15a ; plate 22, figure 17

Type species.-Radforthia radiata n. sp. (cf. pl. 16, figs. $15,15 \mathrm{a} ; \mathrm{pl} .22$, fig. 17) from the Chagrin shale and the upper part of the Ohio shale at localities 6 and 7 , the Cleveland member of the Ohio shale at locality 8 , the Bedford shale at localities 1,6, and 7, the Sunbury shale at locality 9 , and the Logan formation at locality 7.

Diagnosis.-Spores trilete, oblate lenticular, known only from proximodistal compressions, subcircular to subtriangular in transverse outline, $30 \mu-95 \mu$ in diameter.

Trilete suture distinct, extended nearly to the equator; suture margins simple.

Proximal spore coat with distinct radiating grooves and ridges, with corresponding minor variations in thickness; surface otherwise granulose or smooth. Distal coat not ridged, surface smooth or granulose.

Spore coat as much as $4.2 \mu$ thick as measured in optical section at the equator; probably somewhat thinner at the poles; mostly dense, reddish brown by transmitted light; corroded specimens lighter.

Discussion.-These spores are very distinctive and widely distributed and will evidently serve for use in micropaleontologic studies. A valid name is needed to refer to them. This new generic name is proposed in honor of Norman W. Radforth, of McMaster University, in recognition of his contributions to paleobotany and the study of plant microfossils.

The affinity of these spores is not known. Their very characteristic form and appearance signifies that a natural taxon is represented. It is now presumed to belong among terrestrial vascular cryptogamic plants.

Occurrence.-Radforthia is represented in the upper part of the Ohio shale, the Chagrin shale and Cleveland member of the Ohio shale of Late Devonian age, and in the Bedford and Sumbury shales and Logan formation of Early Mississippian age in Ohio.

\section{Radforthia radiata $n$. $s p$.}

Plate 16, figures $15,15 a$; plate 22, figure 17

Diagnosis.-Spores trilete, oblate lenticular, known only from proximodistally compressed specimens, subcircular to subtriangular in outline, $35 \mu-92 \mu$ in diameter (9 specimens measured).

Trilete rays distinct, commissure often separated (pl. 22, fig. 17).

Proximal radiating grooves and ridges described for the genus. Surfaces otherwise smooth.

Spore coat $0.9 \mu$ (on corroded specimens) to $4.2 \mu$ thick; density by transmitted light proportional to spore coat thickness.

Holotype.-Plate 22, figure 17, from upper part of Bedford shale, locality 6 , maceration 438 , slide 5 .

Discussion.-A spore of similar type was illustrated by Naumova (1953, pl. 22, fig. 111) and referred to by her as Stenozonotriletes ornatissimus (nomen nudumno description). According to the position of the illusstration on her plate 22, this type of spore is of early Middle Devonian age. The spore illustrated is about $47 \mu$ in diameter, apparently thick walled with radiating ribs and a dark central area. It may be conspecific with the form named here.

These spores are also closely comparable with those described as type $\mathrm{E}_{17}$ by Radforth and McGregor (1954, p. 611; pl. 2, fig. 37), from the Battery Point formation of Middle Devonian age, L'Anse-Brilliant, Gaspé, Quebec. Spores of type $\mathrm{E}_{17}$ amounted to approximately 6 percent of the assemblage obtained from the Battery Point formation and range from $38 \mu$ to $45 \mu$ in diameter, smaller than all but one (from the Logan formation) of the specimens found during this investigation. 
Hoffmeister, Staplin, and Malloy (1955a, pl. 3, fig. 7) illustrate a spore, $37 \mu$ in diameter, from the "Stanley formation, Oklahoma-Texas." The spore is circular, trilete, and is said to possess numerous ribs on the distal surface. According to Hoffmeister, Staplin, and Malloy, it represents a new genus ("Radiaspora") of Stanley (earliest Pennsylvanian) age. If the radiating ribs are distal and not proximal, the Stanley forms must be distinct, but the illustrations bear a most remarkable resemblance to the forms illustrated by Naumova, by Radforth and McGregor, and in this paper.

Occurrence.-Spores rare; present in the Chagrin shale and upper part of the Ohio shale at localities 6 and 7 , the Cleveland member at locality 8 , the Bedford shale at localities 1,6 , and 7 , the Sunbury shale at locality 9, and the Logan formation at locality 7 (pl. 23).

\section{UNIDENTIFIED SPORES}

Spore type A

Plate 19, figure 5

Description.-Spores trilete, $90 \mu-95 \mu$ in total diameter, subtriangular in proximal view; outline undulating. Trilete rays distinct, extending nearly to outer margin of rim or flange; lips about $3 \mu$ high towards proximal pole. Proximal surface smooth. Cingulum $7 \mu-12 \mu$ in width, margin sinuous; undulant ridges, partly anastomosing, present on distal surface.

Discussion.-The undulant margin of the cingulum is similar to that of the somewhat larger spores of Mirisporites Potonié and Kremp (1954). However, the thicker cingulum and irregularly anastomosing distal ridges are more like those on spores of Reticulatisporites crassus.

Occurrence.-Two examples, poorly preserved, were found in different samples of the Bedford shale at locality 1.

\section{Spore type B}

Plate 19, figure 6

Description.-Spore trilete, $44 \mu$ in diameter, triangular in outline with corners sharply defined. Trilete rays highly developed with prominent lips. Spore coat granulose, $2.9 \mu$ thick.

Discussion.-In shape, size, and development of the lips, this specimen is similar to that described from the Hardinsburg sandstone by Hoffmeister, Staplin, and Malloy (1955b, p. 398, pl. 39, fig. 8) as spore type E.

Occurrence.-The only specimen found is from the Bedford shale at locality 1.
Spore type C

Plate 19, figure 8

Description.-Spores of this tetrad about $66 \mu$ in axial length, $97 \mu-105 \mu$ measured transversely, expanded distally and flattened proximally, yellowish orange by transmitted light. Trilete rays obscure, apparently extending to inner margin of arcuate ridges. Contact areas smooth(?), arcuate ridges prominent. Distal spore coat about $3 \mu$ thick, densely set with sharply acuminate spines as much as $5.6 \mu$ in length and about $3 \mu$ in diameter basally.

Discussion.-It has not been possible to relate this tetrad to any of the spores in the assemblage. Additional specimens were not noted so that the alliance of these spores remains in doubt.

Occurrence.- Spores were found in the Bedford shale at locality 1.

\section{Spore type D}

Plate 18, figure 13

Description.-Spores trilete, $98 \mu-103 \mu$ in diameter including ornamentation. Trilete rays distinct, about four-fifths the spore radius in length. Proximal surface somewhat rugose (preservation?) ; distal surface ornamented with closely spaced wide-based blunt processes, $3 \mu-9.4 \mu$ in length and $3.5 \mu-12.6 \mu$ in width, usually smaller and less densely set toward the proximal pole. Spore coat apparently more than $2 \mu$ thick, dark brown by transmitted light.

Occurrence.-A few spores were found in the Bedford shale, locality 1 , and in the Logan formation, locality 7 .

\section{UNIDENTIFIED DERMAI AND SUBDERMAL STRUCTURES}

Sclerenchymatous "nests"

Plate 21, figures $4,5,5 a$

Description.-Central "nest" cellular; smaller specimens planoconvex in form, subcircular, larger specimens more uniform in thickness and less regular in outline, 0.3 to more than $2.0 \mathrm{~mm}$ in diameter, with a variable usually narrow margin of attached cuticle. Open cell lumens pitting convex (interior?) surfaces of "nests", circular to elliptical, $20 \mu-58 \mu$ in diameter; double walls striate, $6 \mu-8 \mu$ thick; cells arranged in radial pattern; planar (external?) surface smooth.

Attached cuticle relatively thick and uniform, visible around nest in a broad to narrow zone, broken margins angular, probably continuous over the planar central surface but inconspicuous; epidermal cell pattern prominent in the border, cells rectangular to isodiametric, $35 \mu-88 \mu$ broad, $53 \mu-140 \mu$ long, long axes sub- 
parallel. Stomata, hairs, and venation lacking from the epidermis in area surrounding the central "nest."

Cuticle yellow, central "nest" yellowish to reddish brown, appearing resinous by transmitted light.

Discussion.-A description of this type of vegetative tissue fragment is given because the fragments are a persistent and characteristic plant microfossil in the Bedford shale and Berea sandstone. Later studies may indicate that a binary name may be needed to refer to them.

Apparently these fossils are morphologically identifiable as "nests" of subdermal sclerenchymatous cells with an attached eqidermal cuticle. This interpretation was suggested by J. M. Schopf after the cuticle was observed; before significance of the attached cuticle was appreciated, the resinous appearance of the central cell group had suggested comparison with waxy envelopes of certain colonial algae. Interpretation of these objects as sclerenchymatous "nests" is still not wholly satisfying. Larger and more complete specimens are required to fully demonstrate the anatomic inferences.

Most of the "nests" from the Berea sandstone are evidently abraded and cuticle is virtually lacking, as in plate 21, figure 4. The specimen from Bedford shale shown in figures 5 and 5 a, plate 21 , is surrounded by an unusually broad zone of cuticle that shows well the pattern of epidermal cells. The long axes of epidermal cells tend to be oriented in one direction (upper left to lower right in fig. 5), probably signifying axial orientation of the plant. Other examples show similar cuticular vestiges and fully demonstrate the organic relationship. The examples from which cuticle is almost lacking are more characteristic of sandy facies.

Occurrence.-These microfossils are abundant in the Berea sandstone at locality 5 and in the upper part of the Bedford shale at locality 3. A few specimens were observed in the Bedford shale at locality 1, the upper part of the Bedford shale at locality 9 , and the Cuyahoga and Black Hand formations (undifferentiated) at locality 7 (pl. 23). None have been observed in beds of Late Devonian age.

\section{Kingdom UNCERTAIN \\ HYSTRICHOSPHAERIDS}

Description.-Problematic microfossils, cystlike, globular, with bilateral, radial, or centric symmetry, small (range from $4 \mu$ to $200 \mu$, most $50 \mu-100 \mu$ in diameter), with a thin wall of organic composition. Wall of some microfossils perforated, laterally or terminally, by a large circular or oval pore (pylome) for discharge of protoplasmic contents. Wall resistant to hydrofluoric acid and to oxidizing reagents; either yellow or brown and translucent, or opaque, black and highly carbonaceous; smooth or variously ornamented by reticulation, spines of varying complexity, tubes or fibrils.

Discussion.-A diversified assemblage of microfossils, evidently planktonic and marine, may be included in the hystrichosphaerids; the range of genera included in the hystrichosphaerids, usually regarded as a family, exceeds that of a family of normal relationship. In view of the difficult problems involved in the classification of marine plankton, some authors have suggested that many algae, fungi, and protozoans should be assigned to a third organic kingdom, Protista. Others point out that this disposition merely substitutes two difficult boundary lines for the existing one. Furthermore, no accepted rules of nomenclature have been established for the Protista. If the hytrichosphaerids are placed within the animal kingdom, the family name becomes Hystrichosphaeridae; if they are placed within the plant kingdom, the appropriate name becomes Hystrichosphaeridaceae. This distinction is without significance unless the relationship of the family is determined. Recently, however, Eisenack (1954) has emphasized the essential unity of the hystrichs, their relation to peridineans, and has come to regard them (1954, p. 88-89) as probably phytoplankton. On the basis of less extensive study, both Bashnagel (1942) and Fisher (1953) also consider them algae.

Affinities with Chrysophyta, Pyrrophyta, Euglenophyta, or Chlorophyta seem possible among the seven Divisions into which algae are now commonly classified. Many of the forms in these Divisions are planktonic and highly diversified. Resistant hypnospores (aplanospores), statospores, zygospores or cysts are evidently capable of fossilization in many genera. These structures are noted for their diversity in ornamentation, even from species to species within the same genus (cf. Smith, 1938, p. 184-185). Many forms seem to have had a long geologic history within a most stable environment. Many features suitable for use in taxonomic differentiation do not seem important as aids to phyletic survival. Evidently wall composition also may vary and the relation of composition to geologic preservation is uncertain. For example, cenobia of Pediastrum, walls of which have long been regarded as cellulosic, recently have been discovered to be well preserved in several occurrences in Tertiary beds (Wilson and Hoffmeister, 1953; Cookson, 1953). It seems reasonable to consider that many of the hystrichosphaerids could be derived from planktonic algae and this may aid in appreciation of the difficulties inherent in their classification.

The "unity" of the hystrichosphaerids depends greatly on recognition of the pylome, a pore for liberation of 
contents at maturity, which is apparently consistent in size and position on the body of the cyst. This feature also serves importantly in relating the hystrichs and the Dinophyceae. Unfortunately, it may be invisible or absent in many individuals so that this structure is not generally available for differentiation of species or genera. The pylome was not observed in any specimens during the present investigation and it is only with reference to the excellent papers of Wetzel (1933), Eisenack (1951, 1954), and others, that one may be confident of its existence.

Under these circumstances the affiliation of some groups, Tasmanites for example, remains in doubt. Generic determination depends on secondary characteristics that may not be functionally significant, although inheritable. Homomorphy in simple structures is highly probable and may even appear in structures that are not as simple and which, in some instances at least, have become functionally adapted. The forked spines characteristic of some species of Hystrichosphaeridium Deflandre, are one such example. Similar spines are present on the zygospores of Straurastrium fulcigerum. Breb., one of the desmids (Chlorophyta; see Smith, 1938, p. 88 ). The possibility of true relationship here is not disproved, although present day desmids seem restricted to fresh water. However, among groups known to be unrelated, bifurcate spines are also present on the megaspores of Dicrospora, on the tests of Chitinozoa, on the massulae of Azolla. Bifurcate spines also are present on statoblasts of some modern freshwater Bryozoa.

The possible diversity of hystrich relationship and difficulties of classification is emphasized by Deflandre (1952), but he $(1945$, p. 24) feels these are, for the moment at least, of secondary importance, "le but étant, surtout d'instaurer un classement commode, susceptible, comme toujours, d'améliorations ultérieures."

Occurrence.--Hystrichosphaerids have been found in upper Precambrian to Recent rocks (dolomite, limestone and marl, chert, phosphatic rock, shale, and finegrained sandstone) according to Wilson and Hoffmeister (1955). In Paleozoic rocks they are usually associated with marine animals and are most commonly noted in conjunction with scolecodonts, conodonts, and chitinozoans. Hystrichosphaerids also occur with fossil plant spores and pollen but, according to Hoffmeister (Armstrong, 1953), ${ }^{8}$ frequencies are inversely proportional, the hystrichosphaerids become more abundant as distance from shore increases. Erdtman (1954) reports observations of dinoflagellate cysts and other hystrichospheroid bodies in conjunction with ter-

\footnotetext{
${ }^{8}$ See also U.S. patent No. 2,686,108; William S. Hoffmeister, assignor to Standard Oil Development Co., Aug. 10, 1954.
}

restrial pollen in marine sediments off the southwestern coast of Sweden. Wilson and Hoffmeister (1955) suggest that modern forms are relatively ubiquitous and that they occur in brackish and marine deposits, of subtropical to arctic latitudes, which accumulated in waters both shallow and deep.

Microfossils identified with species of Hystrichosphaeridium are present in the Upper Devonian and Lower Mississippian rocks in Ohio. They are fairly abundant in some samples. Specimens that seem referable to Micrhystridium are most abundant in the lower part of the Chagrin shale. Lack of previous reports must be attributed to the relatively small size of the microfossils and the need for an appropriate technique in preparing them for observation. Evidently these forms are widespread and further study is very likely to result in an extension of their range.

\section{Genus HYSTRICHOSPHAERIDIUM Deflandre, 1937}

Plate 19, figures 1,3 , 3a ; plate 22 , figures $1,2,3,4,5,6,7,9$

Type species.-Hystrichosphaeridium tubiferum (Ehrenberg) Deflandre, 1934 (=Xanthidium tubiferum Ehrenberg) Deflandre, 1937.

Description.-Body spherical to polyhedral or elongate, usually more than $30 \mu$ in diameter; spinose appendages often present, some as long as $150 \mu$ with elaborated tips. Wall never segmented or composed of plates; equatorial plates lacking.

Discussion.-The genus is broadly interpreted in keeping with the known variability of planktonic cysts. Deflandre (1952) notes about 68 species of Hystrichosphaeridium described prior to 1952.

Occurrence.-The type species is from Cretaceous flints of the Paris Basin. Eisenack (1951) reports this genus from material of Late Cambrian, Ordovician, and Silurian age in the Baltic area. Klumpp (1953) has described several species from Eocene borehole samples in Holland, and Eisenack (1954) has described exceptionally well-preserved material from the lower Oligocene "Blue earth" associated with the famous amber occurrences in Samlandes (East Prussia). Species reported below are from beds of Devonian and Mississippian age.

The genus is exceptionally long ranging, and species must be relied on for any possible distinctions in age determination.

Hystrichosphaeridium trispinosum Eisenack, 1938

Plate 22, figures $1,2,3,4$

Description.-Body flattened, subtriangular, $9 \mu-33 \mu$ in radial diameter (commonly about $20 \mu$ ) exclusive of spines, $25 \mu-95 \mu$ overall, with a spine at each angle. 
Spines simple, subequal, $7 \mu-35 \mu$ long, hollow for about half their length, tapering gently to a sharp point. Wall smooth, may be slightly folded, about $0.5_{\mu}$ thick, bright yellow by transmitted light.

Discussion.-M. C. White (1862, p. 386, figs. 1 and 2) illustrates two very similar forms, included among "various species of Xanthidia" of Middle Devonian age. Bashnagel (1942, pl. 1, figs. 6 and 7 ) also illustrates similar forms of Middle Devonian age which he refers to species of living autosporic fresh-water algae, Teträedron Kutzing of the Order Chlorococcales. Fisher $(1953$, pl. 7, figs. 6, 8, 9, 10) illustrates forms from the Silurian Neahga shale of Sanford $(1933,1935)$ and Maplewood shale of Chadwick (1918) which he refers to Hystrichosphaeridium geometricum Deflandre (1945). He notes that the microfossils apparently have little relief and appear almost flat. From his description it appears that the microfossils he studied usually have 1 long and 2 shorter spines. Those here referred to $H$. trispinosum have spines of more uniform length. Fisher's specimens are comparable in size to the present species and, except for the difference in spines mentioned above, appear more like $H$. trispinosum than $H$. geometricum. The latter is described by Deflandre as having a thicker brown wall with dark thickened "veins" extending from the tip of each spine, some branching, and joining towards the center of the triangular body. Specimens of $H$. trispinosum are similar in shape and proportion but possess a membranous bright-yellow wall and lack "veins."

Deunff (1954, fig. 2, p. 240) has identified H. trispinosum from Middle Devonian (Upper Couvinian) beds in Brittany. The specimen he illustrates shows 2 long spines and 1 much shorter, and the spines appear solid almost to their base.

Only about half of the specimens from the Ohio and Chagrin shales (pl. 22, fig. 1) fall within the size range of the species $(80 \mu-100 \mu$ for specimens measured from spine tip to spine tip) as determined by Eisenack (1938, p. 14 and 15 ; type, fig. 2). The smaller specimens from Ohio are apparently identical with his in other respects. There is a possibility that the material from Ohio may represent a separate subspecies or a varietal form.

The possibility was investigated that these microfossils might be tetrahedral in form, like Teträedron, and possess a fourth spine. Although a fold in the wall sometimes might be mistaken for an additional spine, none of the many specimens studied ever showed a fourth spine. Most convincing evidence that only three spines are present is obtainable when specimens are tilted almost on edge, as shown on plate 22 . figure 2.

Small pyritic crystals and aggregates frequently occur inside the central body (plate 22, figs. 1, 3, and 4).
Presumably, the pyrite was deposited prior to consolidation of sediment. If this is true, it provides further evidence that the original shape of the body was triangular and flattened, similar to the fossil form now shown.

Occurrence.-Specimens of Hystrichosphaeridium trispinosum are present in the Olentangy shale, Huron member of the Ohio shale and Chagrin shale at locality 8 ; the Ohio and Bedford shales at locality 7 ; from the zone of foerstian remains to the top of the Bedford shale at locality 6 ; and the Bedford shale at locality 9 . They occur abundantly in the Chagrin shale (pl. 23).

Hystrichosphaeridium cf. H. longispinosum (Eisenack) Eisenack, 1938

Plate 19, figures $3,3 a$; plate 22 , figures $5,6,7$

Description.-Body oval to subspherical, multispinose, elliptical to subcircular with arcuate folds when compressed, $21 \mu-33 \mu$ in diameter. Spines variously curved, of 2 orders: major spines (2), subopposite, hollow and about $2.5 \mu-6 \mu$ broad basally, tapering gently to a sharp point, $20 \mu-32 \mu$ long; minor spines (10-24) distributed uniformly, solid and $1.3 \mu-2.0 \mu$ broad basally, $15 \mu-27 \mu$ long, tapering to a sharp point, with narrower shafts than on major spines. Wall smooth, membranous, about $1 \mu$ thick, bright yellow by transmitted light.

Discussion.-As indicated by the preceding description, the forms from Ohio are probably distinguishable from the Silurian form of $H$. longispinosum. There is no question that subopposite major spines occur on the specimens from Ohio, but it is not so clear whether similar spines are absent from material described by other authors. The spines are generally curved and bent, and the differences in spine sizes are not spectacular; so it is possible that the presence of the two major spines has been overlooked. Their oriented position lends significance to what might otherwise be regarded as a normal variation feature.

A most extreme example is shown on plate 19, in figures 3 and $3 \mathrm{a}$, at different levels of focus. This specimen is from the uppermost part of the Chagrin shale, and the differences between the two types of spines is readily observed. Less extreme examples are illustrated on plate 22 , in figures 5,6 , and 7 . In each example careful examination reveals two stronger major spines in subopposite position. These are indicated by arrows in each figure. Possibly the major spines may define a polar, or axial, position.

The specimens from Ohio are slightly smaller, and the numerous minor spines are shorter in relation to body diameter than Silurian specimens described by Eisenack (1931). Fisher (1953) also describes 
Silurian microfossils referred to $H$. longispinosum which are $25 \mu-34 \mu$ in diameter with spines about $23 \mu$ long. His illustrations are generalized, and it is somewhat uncertain how closely his specimens correspond to the Devonian material from Ohio. Apparently spines of $H$. longispinosum, described by Fisher, are more robust and consistent differences in size of spines are not evident.

Occurrence.-Scattered specimens were found in the uppermost part of the Chagrin shale at locality 1 , the Chagrin shale at locality 8 , and the Chagrin shale, Cleveland member of the Ohio shale, and Bedford shale at locality 6 (pl. 23).

Hystrichosphaeridium ohioensis n. sp.

Plate 19, figure 1; plate 22, figure 9

Diagnosis.-Body spherical, subcircular and with narrow arcuate folds when compressed, $32 \mu-69 \mu$, usually greater than $45 \mu$, in diameter. Spines numerous (3550 ), subequal, slightly curved, $2 \mu-3.5 \mu$ broad basally, tapering uniformly to a sharp point, $8 \mu-21 \mu$ long. Wall smooth, $1 \mu-1.8 \mu$ thick, light yellow to bright yellow by transmitted light.

Holotype--Plate 22, figure 9, from the Chagrin shale, locality 6 , maceration 419 , slide 5 .

Discussion.-These microfossils are quite similar to those described from the Silurian rocks of the Baltic area as Hystrichosphaeridium brevispinosum (Ovum hispidum brevispinosum Eisenack, 1931, p. 111) but, instead of having spines with rounded tips, those of the Ohio shale have sharp, distinctly pointed, spines. Neither Bashnagel (1942) nor Fisher (1953) report similar forms. Apparently the species from Ohio is distinct.

Occurrence.-Very common in the Ohio shale or its equivalent at localities 6-8 and 10, the Bedford shale at locality 2 , and the Bedford shale and Berea sandstone at locality 9 (pl. 23).

\section{Genus MICRHYSTRIDIUM Deflandre, 1937}

\section{Plate 22, figure 8}

Type species.-Micrhystridium inconspicuum (Deflandre) Deflandre, 1937.

Description.-Body globular or subpolyhedral, usually less than $20 \mu$ in diameter, often spinose or ornamented; ornamentation and appendages various. Wall nonsegmented; plates lacking.

Discussion.-This genus includes planktonic cystiform fossils, virtually similar to those included in Hystrichosphaeridium except for their smaller size. Differences in size are chiefly useful as a basis for specific differentiation. Micrhystridium may have merit chiefly as a convenience in classification of very minute material.

Occurrence.-Apparently Micrhystridium has about the same extensive distribution as Hystrichosphaeridium although, because of its smaller size, it has been less frequently reported. The type species and several others are present in the Cretaceous flint of the Paris Basin (Deflandre 1937). Deunff (1954) reports two species from the Middle Devonian of Brittany. Deflandre (1945) and Fisher (1953) report occurrences in beds of Silurian age. This genus is represented in Upper Devonian and Lower Mississippian rocks in Ohio.

\section{Micrhystridium sp. A \\ Plate 22, figure 8}

Description.-Body spherical, spinose, with narrow arcuate folds when compressed, $14 \mu-19 \mu$ in diameter. Spines, 18-31, subequal and uniformly disposed, solid, $1.5 \mu-3 \mu$ in width basally, tapering to a sharp point, $4 \mu-8 \mu$ long, some slightly curved. Wall smooth, membranous, about $0.5 \mu$ thick, light yellow by transmitted light.

Discussion.-These forms are a little larger than those Deflandre (1945) referred to $M$. parinconspicuum (body $14 \mu-19 \mu$ versus $9 \mu-13 \mu$ ) but smaller than the largest of the American forms Fisher (1953) doubtfully referred to the same species $(8 \mu-28.5 \mu)$. The spines may be a little more numerous on the specimens from Ohio, but their proportions are relatively similar. The greatest contrast derives from the fact that Deflandre's specimens were black and completely opaque. It is uncertain what emphasis should be placed upon this feature, which may be only an effect of difference in preservation. Fisher's specimens from the basal Maplewood shale of Chadwick (1918) are apparently very similar to this form found in younger beds in Ohio.

Occurence.-These microfossils were found in the Ohio shale at locality 7 (rare), Huron member of Ohio shale and Chagrin shale at locality 6 and 8 , and the lower part of the Berea sandstone at locality 9 (pl.23). They are most numerous at the base of the Chagrin shale at locality 8 .

\section{DISSEMINULES OF UNKNOWN RELATIONSHIP}

Most noteworthy of fossils to be placed under this most noncommittal heading is Tasmanites, a group abundantly represented in Upper Devonian and Lower Mississippian rocks in the United States. These fossils are sporelike in general form and in composition. For many years these, and other fossils superficially resembling them, were reported under the term "Sporangites." The confusion surrounding this name is 
discussed by Schopf, Wilson, and Bentall (1944) and will not be repeated. More recently Schopf (1957) reviews the important contributions of Kräusel (1941) and Lang (1945) dealing with these problematic fossils of marine association. Many of the references to sporangite occurrences probably apply to fossils assignable to Tasmanites, and if this is understood, one may better appreciate their general abundance. Nevertheless, these fossils are not present everywhere, even in black shale where they have been most commonly observed. Surprisingly, no systematic survey of the occurrence of Tasmanites in the Upper Devonian and Lower Mississippian beds has previously been made.

The fossils identified by Eisenack (1938) as Leiosphaera resemble some species of Tasmanites in general aspects, and there is confusion about their relationship. If the two are regarded as the same, the name Tasmanites, being older, must take precedence. However, in spite of superficial similarity and misidentification of species on this account, two genera may well be represented. Leiosphaera may have a little smaller size range. Certainly some species are markedly different in composition from Tasmanites (for example, Leiosphaera retigera Deflandre) and, most importantly, a pylome has been repeatedly mentioned for Leiosphaera and evidently characterizes the type specimen of the type species. The pylome has not been observed in any of the thousands of Tasmanites specimens seen during this study, nor has it been observed by others who have had more extensive acquaintance with Tasmanites material.

The optical properties of the disseminule wall are relatively constant, and the composition of Tasmanites is known (Zetzsche and others, 1931). Schopf, Wilson, and Bentall (1944, p. 17) presumed that the lack of nitrogen and similarity in composition to spore coats of higher plants was adequate basis for assigning Tasmanites to the plant kingdom. This evidently is not the case, because Timm (1950, p. 167) has shown that nematode egg shells are composed of waxy substance, similar to beeswax, that is not nitrogenous. Less is known of the composition of Leiosphaera, and the optical properties differ sufficiently in that group so that one is justified in presuming differences and variations enter into the composition of the fossils.

Punctation, although variable, is prevalent in Tasmanites, but not certainly present in Leiosphaera because in those instances where it has been reported, there is reason to suspect that confusion with Tasmanites is involved. Whereas Leiosphaera, by reason of its plyome, may belong with the hystrichosphaerids, the same cannot be said of Tasmanites. Leiosphaera has not been identified in the course of this study, and it seems necessary to keep Tasmanites separate from the hystrichs for reasons just stated.

As a result of uncertainty as to affinity, the function of Tasmanites microfossils is unknown. Like hystrichs, they may represent the cysts of planktonic organisms. It is not entirely certain that they may not represent egg membranes. Some may represent encysted cells, and others may represent algal spores of a different function. The only reasonable conclusion is that in one fashion or another they served purposes of propagation and dissemination.

Tasmanites, like the hystrichs, is characteristic of marine associations. Spores of land plants may be associated with them, but these are evidently forms carried from their source. For example, in different levels at locality 8 , Tasmanites was most abundant in the Chagrin shale when land-plant spores were scarce, and vice versa. Tasmanites is found in abundance with other marine fossils, conodonts for example, but the genus is never present in deposits such as coal beds in which the environment was terrestrial. The Tasmanite deposit in Tasmania, although correlated with the Gretta coal measures in New South Wales, Australia, is itself interlarded with brachiopods that clearly demonstrate marine association.

If one may judge from the great abundance of Tasmanites in some marine deposits, the organisms represented must either be planktonic or nektonic in habit. The common occurrence of Tasmanites in euxinic black shales indicates this was an environment most favorable for fossil preservation of disseminules and that the active organisms were abundant in the vicinity. Signs of former growth or germination are so rare among the myriads of Tasmanites disseminules in the black shales that one tends to regard the euxinic environment as a death trap, rather than as a place favorable to normal function. However, the euxinic trap must have been adjacent to a prolific area of propagation. Aerated waters of the epilimnion could very well constitute such an area, but there is no indication as to the nature of the prolific biota represented.

Although it might be presumed that the foerstians would be more or less correlated in deposition with Tasmanites, this is not the case. If anything, Tasmanites tends to be less abundant in the strata rich in foerstian remains. The spores of foerstians, of course, are entirely different from disseminules of Tasmanites (see Kidston and Lang, 1924) and are not to be confused.

Tasmanites is not restricted to black shales or to visibly carbonaceous beds, although, owing to the resinous or "rusty" appearance of disseminules as viewed in abundant occurrence on hand specimens, the fossils may 
be most evident when they are in a dark matrix. Occasionally they are concentrated in sinuous aggregations reminiscent of worm casts. These occurrences are rare and have never been found with any suggestion of an enclosing egg sac. The sporelike disseminules occur isolated and scattered through a variety of clastic sediments, but they usually appear in greatest profusion on the bedding planes of thin-bedded silty and shaly rocks.

Disseminules of Tasmanites differ from spores of vascular plants in anisotropism when viewed by polarized light. Some extinction is visible in most fossil spores, probably a result of molecular lineation that may be augmented during fossil zation, but the effect is most prominent in thick-walled disseminules of Tasmanites. The effect is similar, but usually not quite so prominent, as that reported by Schmidt (1937) for the seemingly chićinous egg shell of Ascaris megalocephala. Wall thickness and punctation become more evident with use of polarized light, and mineral inclusions can usually be differentiated more easily. The polarization obtainable with polaroid disks is adequate for most purposes, and much of the descriptive information given below has been obtained in this manner. All features are observable by normal methods of illumination with the biological microscope, but use of polarized light expedites the study and improves the accuracy of measurement of various features.

Four features can usually be expressed numerically in description of the fossils. These include total diameter, wall thickness, spacing of puncta, and dimensions of puncta. Other features, such as the manner of folding, color, and anisotropy, are at least indirectly related to wall thickness versus diameter. Spacing of puncta seems least consistent and possibly the least satisfactory of the characters that may be numerically expressed. In some specimens walls of disseminules appear concentrically laminated, and this characteristic also can be used for taxonomic purposes.

Genus TASMaNITES (Newton, 1875) Schopf, Wilson, and Bentall, 1944

Plate 20 , figures $1,2,3,4,4 a, 5,6,7,8,8 \mathrm{a}, 9$; plate 21 , figures 1 . $1 \mathrm{a}, 2$; text figure 10

Type species.-Tasmanites punctatus Newton, 1875 (by monotypy).

Description.-Body spherical, symmetry centric, $25 \mu$ to more than $800 \mu$, usually $50 \mu-700 \mu$, in diameter, discoidal and subcircular, sometimes with lunate or arcuate folds or meridionally split, when compressed. Without trace of haptotypic features or structural modification for germinal exit; spines or appendages lacking. Surface smooth or minutely rugose, usually punctate. Wall $2 \mu-70 \mu$ thick, uniform for each specimen, in some spec- imens concentrically layered. Wall, usually perforated by puncta, thickness variable in different species. Puncta variable, from numerous but often minute and scattered, to rare or virtually absent. Puncta perforations or tubes commonly straight, uniform in diameter, some flared at orifice or on the interior. Light yellow to reddish brown by transmitted light, depending on wall thickness; anisotropic by polarized light.

Discussion.-Tasmanites disseminules do not show any evidence of tetradic association. The wall may split (pl. 20, fig. 7), apparently in relief of tension resulting from compression. The degree and character of folding are an expression of diameter, wall thickness, and normal elasticity or plasticity of the material composing these bodies. It is possible that the split in some specimens, which is not located along any visibly predetermined line, may be occasioned by growth of the internal propagative body, but of this there is no evidence. Mineral matter is irregularly arranged inside the coat of some specimens, and included air bubbles, or manner of folding, observed at low magnification, may simulate haptotypic structures of spores of vascular cryptogamic plants. However, the purely incidental significance of these features is usually plainly evident, or at least highly probable, when the specimens are critically examined.

When specimens of Tasmanites are observed by polarized light (a method suggested to the writer by J. M. Schopf), they show distinct undulatory extinction, appearing much brighter, where not obscured by extinction shadows (pl. 20, fig. 4a; pl. 21, fig. 2), than they do when observed by ordinary transmitted light. Thicker walled specimens, when viewed by convergent light and Bertrand lens, show a biaxial negative, occasionally uniaxial negative interference figure. Abraded specimens observed under crossed nicols often show a crisscross pattern of dark lines. This optical behavior is similar to that exhibited by the egg shells of Ascaris, with which Schmidt (1937) showed that the optical cross section through the egg wall exhibits a negative spherite cross. This is a result of foliate arrangement of submicroscopic rodlets in the wall. In his chapter on the "Fine-structure of protoplasmic derivatives," Frey-Wyssling (1953) mentions Schmidt's results and also describes the optical properties of chitin, cutin, and cellulose, all of which show varying degrees of anisotropism when viewed under appropriate conditions. These methods provide evidence of the physical makeup of the organic material, but they do not directly indicate differences in chemical composition.

Speciation is difficult in Tasmanites because disseminules show relatively few distinctive characteristics. 


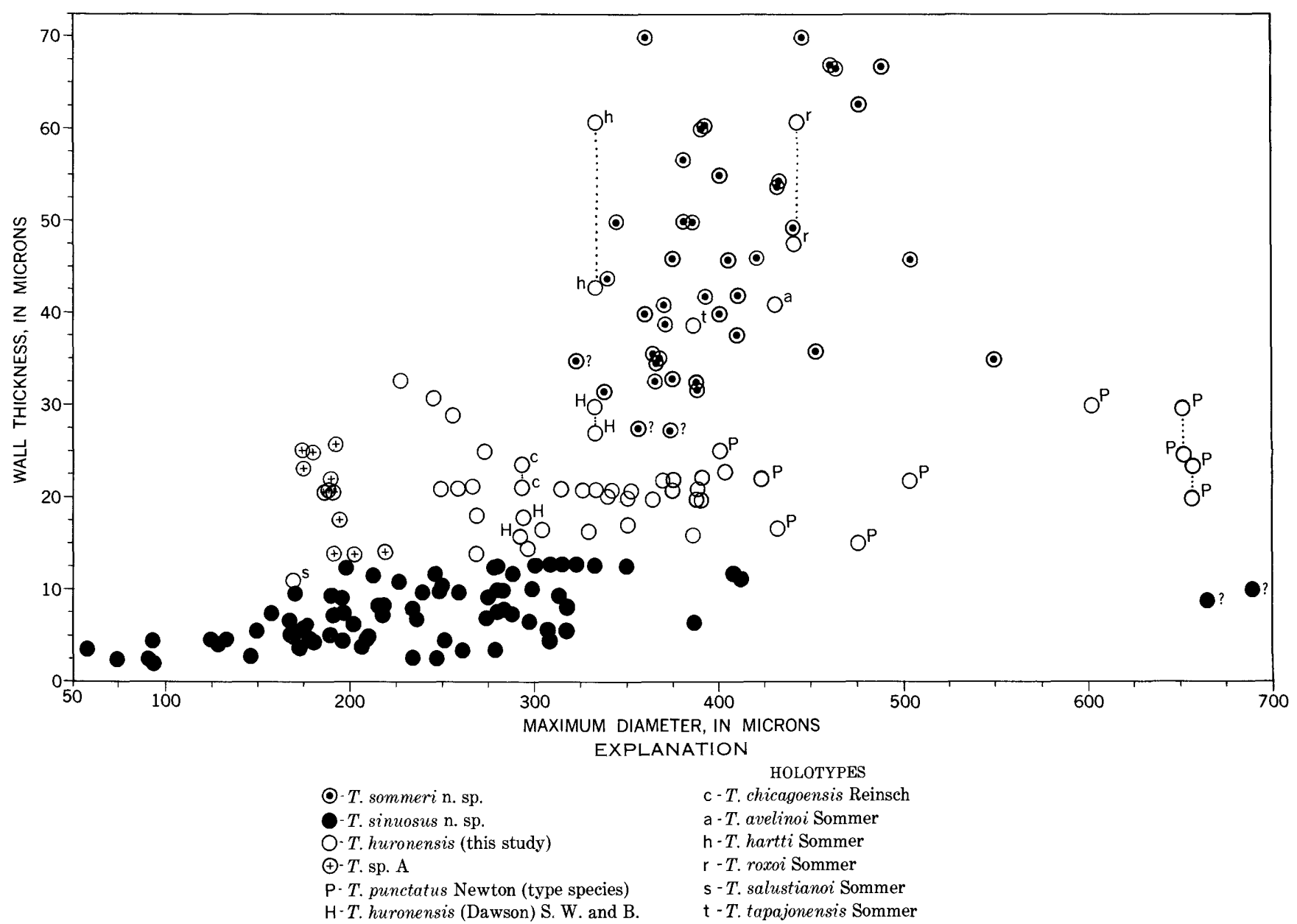

Figure 10.-Diagram of diameter and wall dimensions of Tasmanites disseminules. Dashed lines between identical symbols indicate that the measurement of wall thickness of the specimen is somewhat uncertain within the indicated limits; a question mark beside a symbol indicates uncertain identity.

Of the features available for use, overall diameter of the disseminule and its wall thickness are most definitely determinable. These measurements can be plotted for different individuals to provide a simple basis for estimating the range of variation and correlation of these biocharacters. Such a plotting is presented in figure 10 for species previously described, as well as for new material now reported, since it serves as a convenient basis for comparative discussion. ${ }^{9}$

The type species, Tasmanites punctatus, is described by Newton (1875) from the Tasmanite deposit of Permian age in Tasmania. He notes their punctate nature and the concentrically laminated appearance of their wall. The dimensions of specimens considered as of T'. punctatus and figured by Newton (1875, pl. 10, figs. $2,3,5,8,9)$, by Dawson (1886, fig. 10), and of one from

other graphs were prepared, based on ratio of wall thickness to diameter and on factors derived as a combined function of diameter, wall thickness, and puncta spacing, according to the method suggested by Burma (1948). None of these graphs seemed as easy to evaluate for purposes of comparison as the simple plotting here adopted. a Tasmanite specimen as measured by the author, are indicated on figure 10 by the letter $\mathbf{P}$.

The dimensions of the specimen indicated as $T$. chicagoensis (see Schopf, Wilson, and Bentall, 1944) by Reinsch (1884, v. 2, p. 4, pl. 72a, fig. 76) are indicated on figure 10 by the letter $c$.

The dimensions of specimens of $T$. huronensis, as illustrated by Dawson (1886, figs. 4, 5, 6), are indicated on figure 10 by the letter $\mathrm{H}$.

Dimensions of most of the holotypes of the species described by Sommer (1953) are indicated on figure 10 as follows: T. tapajonensis $(\mathrm{t}), T$. roxo $i(\mathrm{r}), T$. avelinoi (a), T. hartti (h), T. salustianoi (s). The illustrations and descriptions of $T$. mourai, $T$. euzebioi, and $T$. derbyi are not conclusive enough to allow similar indication. Sommer's study of Tasmanites from a sample of Brazilian shale of Devonian age, correlated with the Hamilton group, is the first recent study attempting speciation within the genus.

New material described under this genus is indicated 
in figure 10 by solid circles (T. sinuosus n. sp.), crossed circles ( $T$. sp. A), open circles ( $T$. huronensis), and dotted circles (T. sommeri n. sp.). This plotting of dimensions suggests the extent of overlap in size of the various forms and indicates a source of difficulty in specific determination.

In addition to records of Tasmanites from Tasmania, Brazil, and the United States, the genus is evidently represented in the Lower Limestone Shales closely overlying the Upper Old Red Sandstone at Drybrook, Forest of Dean, in Gloustershire, located to the east of the South of Wales coal field. Wethered (1886) discusses the occurrence and presents illustrations both from Newton's paper and from original material, obtained from Orton in Ohio, for comparison. Apparently the Glouster material is from lowermost Lower Carboniferous rocks.

Disseminules reminiscent of Tasmanites are described as Perisaccus by Naumova (1953). Her descriptions are brief and the drawings, by which this work is illustrated, do not seem sufficiently critical to serve as a basis for independent judgment of relationship. Perisaccus might be allied with Leiosphaera, or it might differ more than the general appearance of the drawings would lead one to suspect. Nevertheless, it would be strange if Tasmanites were entirely absent from the Russian material of Late Devonian age. It should be present there in beds of marine origin.

Schopf, Wilson, and Bentall (1944, p. 18) mentioned the possible assignment of Sporangites alaskensis $\mathrm{D}$. White and $S$. arctica D. White (White, 1929) to Tasmanites. Both species are probably of Early Cretaceous age, although the former may possibly be older. Both species were studied by White from thin sections, and some uncertainty remained as to their characterization.

Some of the original sample of brown oil shale from the Kivalina basin, from which White's Sporangites alaskensis had been described, was made available to the writer through kindness of Taisia Stadnichenko, of the Geological Survey. The Meade River material (source of $S$. arctica) was no longer available.

Macerations of the oil shale from the Kivalina River area showed that the sporelike specimens are nearly all of one kind and are indeed referable to Tasmanites. No "crests," apparent or otherwise, are present; nor is a pylome represented. The wall is characteristically punctate and the concentric zonation, which White describes as an "envelope" and discusses in some detail, is evident but not very prominent. The appearance of "palisade cells" described by White is apparently only a reflection of straight perforations (puncta) normally traversing the wall.
This species should be added to the list of those referable to Tasmanites as T. alaskensis (White) Winslow n. comb. This record of the genus is the youngest that the writer has been able to confirm.

Occurrence.-Tasmanites is reported in the upper Niagran (Middle Silurian) of northern Illinois by Lowenstam (1948) who discusses the marine invertebrate associations $(1948$, p. $77,79,84-85,128,138)$. Determinations were confirmed by Kosanke. Very similar forms occur in Gothlandian (Silurian) rocks of the Baltic where they have been identified as Leiosphaera by Eisenack (1938). Apparently the genus is widely distributed in the Middle Devonian of Brazil. It is often abundantly represented in Upper Devonian and Lower Mississippian beds in North America. It has been reported from the basal Lower Carboniferous in England. The original indentification of Tasmanites was from beds regarded as Permian in age in northern Tasmania. Its youngest known occurrence is in beds of probable Early Cretaceous age in northwestern Alaska.

Tasmanites huronensis (Dawson) Schopf, Wilson, and Bentall, 1944, emend. Winslow

Plate 21. figure 1, 1a; text figures 10, 11

Protosalvinia huromensis Dawson, 1886, p. 115, figures 4, 4a, $4 \mathrm{~b}, 5,6,6 \mathrm{a}, 7 \mathrm{~b}, 11,12(?)$

Description. - Disseminules spherical; $200 \mu-450 \mu$, commonly $250 \mu-400 \mu$ in diameter, discoidal and subcircular, sometimes with 1 or 2 arcuate folds, as compressed. Surface smooth to minutely rugose. Wall $12 \mu-35 \mu$ (commonly $18 \mu-23 \mu$ ) thick, punctate. Puncta numerous, tubular, about $1 \mu$ in diameter, straight, radially alined, often abruptly and shallowly flared on the interior; interior pore spacing $15 \mu-21 \mu$. Yellow to orange by ordinary transmitted light; more brilliant and strongly anisotropic, usually giving an interference figure, by convergent polarized light; frequently glistening or with resinous appearance by reflected light.

Lectotype.-A pparently no type has previously been designated for this species. A nomenclatural type is essential if the application of the name is to achieve stability. A lectotype is herewith proposed with reference to the specimen illustrated by Dawson (1886, figs. $4,4 a$, and $4 \mathrm{~b}$ ), which is reproduced here as figure 11 .

Sporangites huronensis was first proposed by Dawson (1871a) in the "American Journal of Science" ("Silliman's Journal"), and the same article was reprinted both in the "Annals and Magazine of Natural History" (Dawson, 1871b) and in the "Canadian Naturalist" (Dawson, 1871c) during the same year. The same 
illustrations are reproduced in all three, and all illustrations are equally ambiguous, if not misleading. Only a diameter can be established from these figures. A summary of the description of $S$. huronensis was also published in 1871 without any illustrations (Dawson, 1871d). In none of these publications can the species be said to be usefully or definitely characterized, and if we were to rely exclusively on these publications, we would have to conclude that the species is just as ambiguous as is the generic term "Sporangites." Schopf, Wilson, and Bentall, 1944, p. 12-15.)
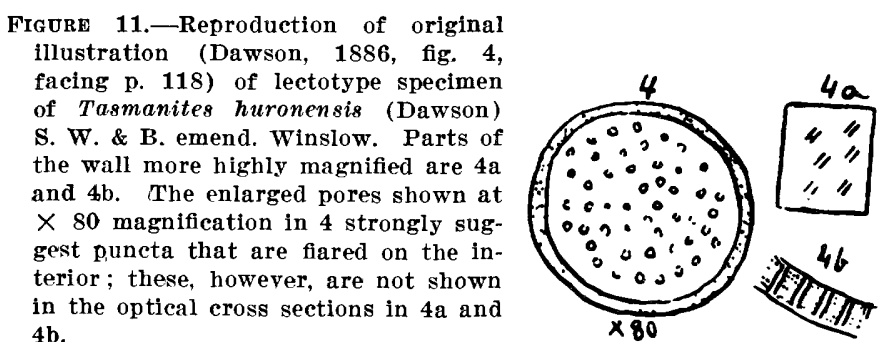

Varying usage of the term "Sporangites" caused it to be abandoned as an ambiguous name (nomen ambiguum), but the specific name probably can be used in combination with Tasmanites (as suggested by Schopf, Wilson, and Bentall) if Dawson's revised concept of 1886 is adopted and if a specimen then illustrated is accepted as the type. Because a name has no standing that cannot be related effectively with its nomenclatural type, the priority of $T$. huronensis (Dn.) S. W. \& B. emend. Winslow dates from 1886, rather than 1871 when the name itself was first proposed in a very ambiguous manner.

Subsequent validation of a nomen nudum is not a recommended nomenclatural procedure, but it is sanctioned. Thus, it seems reasonable to extend the practice to include clarification of a name initially published ambiguously, especially if by doing so a familiar designation can be stabilized in a manner consistent with desirable common usage. If the procedure proposed here is not adopted, the alteruative would be to apply the epithet "huronensis" to all "small globular papillate spore cases" in ancient rocks; but this alternative does not seem, at the present time, to be constructive.

Discussion.-A critical part of the problem of identifying species of Tasmanites concerns $T$. huronensis because this is the species that has been most commonly identified by Dawson and others on the basis of superficial observation and analysis. Resinous specks visible with a hand lens have often been labeled "Sporangites huronensis" without any appreciation of the technical meaning of the name. It would have been better in many such instances to have simply labeled the specimens as "spores(?)" or "sporangites." The result of indiscriminate labeling has been to confuse the results of more critical work and to make it more difficult to report effectively on new material. The generic name became nearly meaningless long before it was discarded, but in combination with Tasmanites, the specific designation is valid and useful if it is properly employed. Considerable attention has been devoted to the identification and differentiation of $T$. huronensis in the present report.

Schopf, Wilson, and Bentall presented Dawson's most adequate description of $T$. huronensis. The foregoing emended description conforms to this usage in general, but it also includes additional information that is needed for discriminating use. The dimensions of three of Dawson's specimens, including the lectotype, are indicated by the circles marked with $\mathrm{H}$ in figure 10, and measurements of 30 other specimens assigned to this species are shown by open circles in the same chart.

The characteristics of $T$. huronensis are not clear cut, and there is a gradual overlap in size and other characteristics with other species. In general, $T$. punctatus is larger; the walls are evidently more definitely laminated, although they include specimens having about the same range of wall thickness. Dawson (1886, p. 110) mentions indications of concentric layering in "typical macrospores from the Erian shales" but gives no indication of it in his description or illustrations of sporangites huronensis. The specimens assigned to the species as reported here correspond remarkably well with Dawson's rather crudely drawn figures. Possibly the wall of some specimens may be faintly laminated, but, if so, this is not at all a prominent or consistent feature. 'Together with size, it serves as a convenient basis for distinguishing $T$. huronensis from $T$. punctatus. The differentiation of $T$. euzebioi and $T$. huronensis, however, is not at all clear. The extent of overlap of forms classed here as T. sommeri n. sp. and $T$. sinuosus n. sp., and others, will be discussed further on in connection with their diagnoses. It seems evident that species of Tasmanites are frequently indistinctly separated and must be regarded a little differently than those of genera in which specific differentiation is more distinct.

Tasmanites huronensis appears to include a circle of affiliation that is usable and identifiable in spite of intergradation toward other forms. The more closely specimens approximate that of the type material, the more definite is the basis for determination. Near the margins of circumscription indicated by the diagnoses, specific determinations are less certain. This is scarcely a new problem in taxonomy; the only unusual feature is the copious numbers of specimens that make it possible to find some variant intergradational forms in al- 
most every direction. In spite of intervariation, there is a very characteristic type of disseminule, features of which tend to cluster around the Dawson type material that is here regarded as authoritative. This serves as a focal point within the intergrading assemblage for identification of Tasmanites huronensis.

Occurrence.-Microfossils of the T. huronensis type are present chiefly in the Olentangy shale and lower part of the Ohio shale below the foerstian zone (pl. 23). They occur in the Huron member of the Ohio shale, which may be equivalent to the lower part of the Ohio shale in areas where members are not differentiated. A single specimen was found above the foerstian zone at locality 6. Dawson's original material is from the Kettle Point beds at Kettle Point, Ontario, which is regarded by Cooper and others (1942) as stratigraphically equivalent to the Olentangy shale and the lower part of the Ohio shale. The general geologic setting of the Kettle Point beds is discussed by Caley (1943, p. 63). A few abraded specimens, referred to T. huronensis with question, were also present in the Cleveland member of the Ohio shale at locality 1 . Possibly these rare examples may have been derived by reworking of material from older beds.

$T$. huronensis is one of the common types present in glacial till and in Quaternary deposits derived from till in the proximity of outcrops of Devonian and Lower Mississippian rocks in the glaciated part of the Eastern United States. Some of the specimens found in glacial deposits, such as that shown on plate 21, figures 1 and 1a, are very well preserved.

\section{Tasmanites sinuosus n. sp.}

Plate 20, figures $1,2,3$; text figure 10

Diagnosis.-Disseminules spherical; $50 \mu-425 \mu$, commonly $150 \mu-325 \mu$, in diameter ( 73 specimens measured), subcircular, larger specimens with intricate folds, when compressed. Surface smooth to minutely rugose. Wall $2 \mu-13 \mu$ (commonly $3 \mu-10 \mu$ ) thick, punctate, not laminated. Puncta numerous, tubular, straight, minute but distinct, smaller than in $T$. huronensis, interior terminations not flared; pore spacing (interior surface) $10 \mu-15 \mu$. Light yellow, often brilliant, by ordinary transmitted light; anisotropic, interference figure indistinct by convergent polarized light; commonly appearing lustrous and waxy by reflected light.

Holotype.-Plate 20, figure 1, from the basal part of the Cleveland member of the Ohio shale, locality 1 , maceration 156, slide 1, collection 1-12-6-53.

Discussion.-As in T. huronensis, T. sinuosus includes an intergradational population which usually is reasonably distinct and characteristic in appearance but, in a given occurrence, nearly always includes some vari- ants trending toward other species. When other species of Tasmanites (for example, T. huronensis or $T$.sp. A) are represented in the same assemblage, intergradational forms seem always present, and some specimens may be almost impossible to definitely classify. When only T. sinuosus is present, the range of variation is not as great. It is principally these latter occurrences that support the view that $T$. sinuosus should be specifically distinguished.

The wall thickness, versus diameter measurements plotted in figure 10, indicate something of the range of variation included here. The specimen selected as holotype is a little smaller than the average for the species and was chosen chiefly with regard to clarity of detail. Specimens in the smaller size range are commonly less distorted by folding, but this seems incidental. Wall thickness does not tend to increase materially with size but seems to remain relatively uniform and characteristic. The specimen illustrated on plate 20 , figure 3 , shows normal wall thickness, although it is relatively larger. It remained uncompressed and unfolded because the interior is filled with pyrite.

The two specimens represented by solid circles at the extreme right in figure 10 are, for the present, excluded from $T$. sinuosus s. s., although they are similar in all respects except for size. They were observed in association with numerous characteristic examples of $T$. sinuosus in the lower part of the Ohio shale at locality 8 (the Huron member of the Ohio shale) and at locality 10 at the base of the Olentangy shale, but no forms in the intermediate size range were present in either place. Further study may show either that they represent another species or that $T$. sinuosus includes a number of varieties characterized by differences in diameter.

It is very difficult to know how closely $T$. sinuosus is related to T. salustianoi Sommer (1953) whose nomenclatural type is located on figure 10 in the circle marked s. Three specimens of T. salustianoi range from $160 \mu$ to $210 \mu$ in diameter. Since geographic separation is great and Sommer's material is older than that described here, it seems best for the present to treat them as distinct. Characteristics of the wall, in general, serve to differentiate $T$. sinuosus from other species.

Occurrence.-Specimens of Tasmanites sinuosus were found in the Columbus and Delaware limestones at locality 7. These microfossils are generally present throughout the Olentangy and Ohio shales and often are abundantly represented in the lower part of the Ohio shale below the foerstian zone and in the upper part of the Ohio shale or Chagrin shale. Rare examples are present in the Bedford shale and lower part of the Cuyahoga formation at various localities. It 
is more widely distributed and seems longer ranging than any of the other forms of Tasmanites distinguished in this study (pl. 23).

\section{Tasmanites sommeri $n$. sp.}

Plate 20, figures 4, 4a, 9(?) ; plate 21, figure 2 ; text figures 10,12

Diagnosis.-Disseminules spherical; $320 \mu-550 \mu$ in diameter (37 specimens measured), tumid, almost circular, not folded when compressed. Surface finely rugose, pitted in some compressed specimens. Wall $30 \mu-70 \mu$ thick, punctate, often laminated, laminae as many as 10 or 12 , thicker toward the outside and thinner centrally. Puncta numerous, interior spacing $18 \mu-35 \mu$ (commonly about $27 \mu$ ), tubular, gradually tapering from about $1 \mu$ in diameter on the outside to $2 \mu-5 \mu$ wide internally, coarser than in $T$. huronensis, but usually not flared on the interior. Yellow to dark orange by ordinary transmitted light; strongly anisotropic, brilliant yellow to dark red, either uniaxial or biaxial negative interference figure with Betrand lens and convergent polarized light; dark red with dull luster by reflected light.

Holotype.-Plate 20, figures 4, and 4a, from the lower part of the Ohio shale, locality 7 , maceration 378 , slide 3 .

Discussion.-The specimens assigned to T. sommeri represent another relatively distinctive type that can usually be easily recognized because of its nonfolded swollen appearance. This appearance and the pronounced anisotropic effect (pl. 20, fig. 4a, and pl. 21, fig. 2) are directly related to the thickness of the wall. Nevertheless, this species also shows intergradation with $T$. huronensis, and its dimensions may also overlap those of T. punctatus; some specimens are so intermediate that they are virtually indeterminable. Three such specimens are represented by dotted circles with question marks in the central part of figure 10. In most specimens, however, the thickness of the wall serves as an adequate basis for distinction.

Some question remains concerning the nature of the wall laminations shown by many individuals assigned to this species. Most of the specimens from localities 7 and 10 show definite wall lamination with structure like that shown in figure 12. However, a number of specimens from localities 6 and 8 did not show layering distinctly, and it is virtually absent from the specimen shown on plate 21 , figure 2 , although the wall here is $40 \mu$ thick. Other dimensions and spacing of pores are similar, regardless of the prominence of lamination; so it seems best to regard lamination as a character that may be variable within rather broad limits. Where present the inner laminae are thinner than those nearer the outside, and in this respect $T$. sommeri seems to differ from $T$. punctatus where available illustrations, at least, suggest no progressive laminal differentiation. Lamination in walls of Tasmanites deserves further study because it may provide a clue to the mode of deposition, function, and affinity of the disseminules.

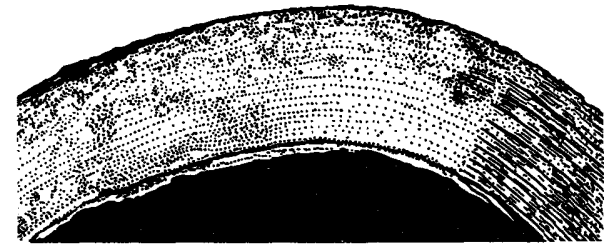

FIgURE 12.-Tasmanites sommeri n. sp. Line tracing from photograph showing the concentric wall layering. Dark central cavity is filled with pyrite. Specimen from the lower part of the Ohio shale, locality 10 , maceration 310 , slide 6 . $\times 250$.

Wall thickness tends to increase directly with overall diameter in $T$. sommeri, as indicated by the spacing of dotted circles in figure 10. The correlation is not exact, yet it contrasts significantly with the relative uniformity in wall thickness shown by $T$. sinuosus, $T$. huronensis, and T. punctatus. In general, this appears to be excellent evidence of at least specific separation, particularly since the dimensions were not plotted until after specific assignments had been made. Nevertheless, such information is of little value for identification of individual specimens in unknown new material.

In addition to the species mentioned above, $T$. sommeri apparently is distinguishable from thick-walled forms described by Sommer (1943) as T. hartti and $T$. tapajonensis by its larger and more widely spaced pores, and possibly by lamination of the wall. T. tapajonensis appears similar to $T$. hartti, but it includes a larger range of sizes, and the punctations are said to consist only of shallow depressions rather than deep pores that perforate the wall. T. avelino i is larger, shows greater range in size, and more definite puncta than $T$. hartti and $T$. tapajonensis, but it also has a nonlaminated wall. T. roxoi is clearly distinguished by the flared orifices of pores. Further comparison is difficult in the absence of more complete information about some of the Brazilian species. The dimensions of type specimens of these species are located in relation to the specimens of $T$. sommeri in figure 10.

Occurrence.-The principal occurrence of T. sommeri seems to be restricted to the Olentangy shale and lower part of the Ohio shale below the foerstian zone, at localities $6,7,8$, and 10 (pl. 23).

Two thick-walled abraded specimens, one of which shows faint concentric lamination ( $p l .20$, fig. 9), were found in the Bedford shale at locality 2 . These might easily result from reworking of older sediments at the time the Bedford was deposited. 


\section{Tasmanites sp. A}

Plate 20, figures 5, 6, 7(?) ; figure 10

Description.-Disseminules $173 \mu-220 \mu$ in diameter (10 specimens measured), flattened but not folded when compressed. Wall $14 \mu-26 \mu$ thick, usually more than $20 \mu$, punctate. Puncta numerous, minute but conspicuous; interior pore spacing about $23 \mu$ (pl. 20, fig. 6). Light yellow to darker yellow centrally by ordinary transmitted light; anisotropic, brilliant yellow to orange by polarized light.

Discussion.-Only 10 specimens have been found, and it is not clear whether a species equivalent to others that have been named is represented. These microfossils are distinguished by their small size and relatively thick walls (pl. 20, fig. 5). The diameter is generally less than in T. huronensis, but the wall is comparable in thickness. Thinner walled examples intergrade with $T$. sinuosus as indicated by location of the crossed circles in figure 10. Specimens shown on plate 20, figures 5 and 6 , were picked directly from the matrix and mounted without maceration. They are lighter in color than those obtained by maceration from immediately overlying beds.

Occurrence.-Specimens assigned to Tasmanites sp. A were found in the Olentangy shale and the lower part of the Ohio shale below the foerstian zone at locality 8 and in the upper part of the Olentangy shale at locality 7 (pl. 23). A few specimens, apparently similar but poorly preserved, were found in the Cleveland member of the Ohio shale and the Bedford shale (redeposition?).

\section{Tasmanites sp.}

Plate 20, figures $8,8 \mathrm{a}$

Description.-Specimen $810 \mu$ in diameter, wall $68 \mu$ thick, puncta numerous, interior pore spacing $43 \mu$. Interior surface minutely irregular, external surface finely rugose. Dark reddish brown, nearly opaque, by ordinary transmitted light; anisotrophic, luminous yellow and red by polarized light; dull dark red by reflected light.

Discussion.-The single specimen illustrated is the only one of this size that has been found. T. avelino $i$ is said to range to as much as $710 \mu$ in diameter (Sommer, 1953 ), and some resemblance is also shown in the similar irregularity of interior surfaces. The puncta, however, appear to be about $12 \mu$ apart in the example Sommer has illustrated. The chief interest in this specimen is in demonstrating the large size that may be attained by disseminules of Tasmanites.

Occurrence.-The specimen was found in the basal part of the Bedford shale, locality 1.

\section{LITERATURE CITED}

Andrews, H. N., and Mamay, S. H., 1951, A new American species of Bowmanites: Bot. Gazette, v. 113, no. 2, p. 158-165. Armstrong, T. A., 1953, New exploration tool-fossil pollen and spores used in new approach to job of determining age of rock formations cut by driller's bit: Oil and Gas Jour., v. 51 , no. 44, p. 64-65.

Arnold, C. A., 1933, A Iycopodiaceous strobilus from the Pocono sandstone of Pennsylvania : Am. Jour. Botany, v. 20, no. 2, p. 114-117.

1935, Notes on some American species of Lepidostrobus: Am. Jour. Botany, v. 22, no. 1, p. 23-25.

1936, Observations on fossil plants from the Devonian of Eastern North America, 1. Plant remains from Scaumenac Bay, Quebec : Michigan Univ., Mus. Paleontology, Contr., v. 5, no. 2 , p. 37-48.

1937, Devonian and Mississippian plant-bearing formations in Eastern America: $2^{\text {eme }}$ Congrès pour l'avancement des études de stratigraphie carbonifère [1935], Compte rendu, v. 1, p. 47-62.

1938, Note on a Lepidophyte strobilus containing large spores, from Braidwood, Illinois: Am. Midland Naturalist, v. 20 , no. 3 , p. $709-712$.

1939 , Observations on fossil plants from the Devonian of Eastern North America, 4. Plant remains from the Catskill delta deposits of northern Pennsylvania and southern New York: Michigan Univ., Mus. Paleontology, Contr., v. 5, no. 11, p. 271-314.

1947, An introduction to paleobotany: New York, McGraw-Hill Book Co., Ine., 433 p.

1948a, The Mississippian fiora: Jour. Geology, v. 56, no. 4 , p. 367-372.

1948b, Some cutinized seed membranes from the coalbearing rocks of Michigan: Torrey Bot. Club Bull., v. 75, no. 2, p. 131-146.

1950, Megaspores from the Michigan Coal Basin : Michigan Univ., Mus. Paleontology, Contr., v. 8, no. 5, p. 59-111. 1954, Fossil sporocarps of the genus Protosalvinia Dawson, with special reference to $P$. furcata (Dawson) comb. nov.: Svensk bot. tidskr., v. 48, no. 2 , p. 292-300.

Balme, B. E., 1952, On some spore specimens from British Upper Carboniferous coals: Geol. Mag., v. 89, p. 175-184.

Bartoo, H. V. K., 1948, Notes on Mississippian plant fossils from the Berea quarry, Berea, Ohio [abs.] : Am. Jour. Botany, v. 35 , no. 10 , p. 805 .

1950, Comparative study of early Carboniferous (Mississippian) plant fossils [abs.] : Am. Jour. Botany, v. 37, no. 8, p. 672 .

Bashnagel, R. A., 1942, Some microfossils from the Onondaga chert of central New York: Buffalo Soc. Nat. Sci. Bull., v. 17 , no. 3, p. 1-8.

Bennie, James, and Kidston, Robert, 1886, On the occurrence of spores in the Carboniferous formation of Scotland: Royal Phys. Soc. Edinburgh Proc., v. 9, p. 82-117.

Berry, Willard, 1937, Spores from the Pennington Coal, Rhea County, Tennessee: Am. Midland Naturalist, v. 18, no. 1, p. $155-160$.

Bocheński, T. A., 1939, On the structure of sigillarian cones and the mode of their association with their stems: Polska Acad. Sci. Pub., no. 7, p. 1-28.

Burma, B. H., 1948, Studies in quantitative paleontology: 1. Some aspects of the theory and practice of quantitative invertebrate paleontology: Jour. Paleontology, v. 22, no. 6, p. $725-761$. 
Butterworth, M. A., and Williams, R. W., 1954, Descriptions of nine species of small spores from the British Coal Measures: Annals and Mag. Nat. History, ser. 12, v. 7, no. 82, p. 753-764.

Caley, J. F., 1943, Paleozoic geology of the London area, Ontario: Canada Geol. Survey Mem. 237, $171 \mathrm{p}$.

Campbell, Guy, 1946, New Albany shale: Geol. Soc. America Bull., v. 57, p. 829-908.

Carman, J. E., 1947, Geologic section of the Chillicothe test core : Ohio Jour. Sci., v. 47 , no. 2 , p. 49-54.

1955, Revision of the Chillicothe test core section: Ohio Jour. Sci., v. 55, no. 2, p. 65-72.

Chadwick, G. H., 1918, Stratigraphy of the New York Clinton: Geol. Soc. America Bull., v. 29, p. 327-368.

Chaloner, W. G., 1951, On Spencerisporites, gen. nov., and S. karczewskii (Zerndt), the isolated spores of spencerites insignis Scott: Annals and Mag. Nat. History, ser. 12, v. 4 , p. $861-873$.

- 1953a, On the megaspores of Sigillaria: Annals and Mag. Nat. History, ser. 12 , v. 6 . p. $881-897$.

- $1953 \mathrm{~b}$, On the megaspores of four species of Lepidostrobus: Annals of Botany, new ser., v. 17, no. 66, p. 263-293.

$1953 \mathrm{c}$, A new species of Lepidostrobus containing unusual spores: Geol. Mag., v. 90, no. 2, p. 97-110.

- 1954a, Notes on the spores of two British Carboniferous lycopods: Annals and Mag. Nat. History, ser. 12, v. 7, p. 81-91.

— 1954b, Mississippian megaspores from Michigan and adjacent states: Michigan Univ. Mus. Paleontology, Contr., v. 12, no. 3, p. 23-35.

Cookson, I. C., 1953, Records of the occurrence of Botryococeus braunii, Pediastrum and the Hystrichosphaerideae in Cainozoic deposits of Australia : Australian Natl. Mus. Melbourne Mem., no. 18, p. 107-123.

Cooper, G. A., and others, 1942, Correlation of the Devonian sedimentary formations of North America: Geol. Soc. Annerica Bull., v. 53, p. 1729-1794.

Cross, A. T., 1947, Spore floras of the Pennsylvanian of West Virginia and Kentucky: Jour. Geology, v. 55, no. 3, p. $285-308$.

—_ 1950, Plant microfossils and the application of their study to coal stratigraphy: Conference on the Origin and Constitution of Coal Proc., Nova Scotia Dept. Mines and Nova Scotia Research Foundation, Crystal Cliffs, Nova Scotia, p. 49-74.

Cross, A. T., and Hoskins, J. H., 1951, Paleobotany of the Devonian-Mississippian black shales: Jour. Paleontology, v. 25 , no. 6, p. 713-728.

- 1952. The Devonian-Mississippian transition flora of east-central United States: $3^{\text {ème }}$ Congrès pour l'avancement des études de stratigraphie carbonifère (1951), Compte rendu, v. 1, p. 113-122.

Cross, A. T., and Schemel, M. P., 1952, Representative microfossil floras of some Appalachian coals: $3^{\text {ème }}$ Congrès pour l'avancement des études de stratigraphie carbonifère (1951), Compte rendu, v. 1, p. 123-130.

Czarnocki, Jan., 1937, Les problémes de la stratigraphie carbonifère du Bassin polonais à la lumière du schéma adopté par le Congrès de Heerlen, $1927: 2^{\mathrm{eme}}$ Congrès pour l'avancement des études de carbonifère [1935], Compte rendu, v. 1, p. 97-108.
Dawson, J. W., 1871a, On spore-cases in coals : Am. Jour Sci., 3d ser., v. 1, no. 4, p. $256-263$.

- 1871b, On spore-cases in coals: Annals and Mag. Nat. History, ser. 4, v. 7, no. 41, p. 321-329.

1871c, On spore-cases in coals : Canadian Naturalist and Geologist, new ser., v. 5 (1870), p. 369-377.

1871d, The fossil plants of the Devonian and Upper Silurian formations of Canada : Canada Geol. Survey, $92 \mathrm{p}$. - 1886, On rhizocarps in the Erian (Devonian) Period in America : Chicago Acad. Sci. Bull., v. 1, no. 9, p. 105-118. 1888, Geological history of plants: Internat. Sci. ser., London, Kegan Paul, Trench and Co., v. 63, 290 p.

Deflandre, Georges, 1937, Microfossiles des silex crétacés. $2^{\text {ème }}$ pt. Flagellés Incertae Sedis. Hystrichosphaeridés. Sarcodinés. Organismes divers: Annales de paléontologie, v. 26, p. 51-103.

- 1945, Microfossiles des calcaires siluriens de la Montagne Noire: Annales de paléontologie, v. 31 (1944-1945), p. 41-75.

1952, Groupes incertae sedis, Groupe des Hystrichosphaeridés, p. 322-326, in Piveteau, Jean [ed.] Traité de Paléontologie, v. premier, Protistes, Spongiaires, Coelentéres, Bryozoires: Paris, Masson et $\mathrm{C}^{\mathrm{i}} \mathrm{e}, 782 \mathrm{p}$.

Delevoryas, Theodore, 1955, A Palacostachya from the Pennsylvanian of Kansas : Am. Jour. Botany, v. 42, no. 6, p. 481-488.

Deunff, Jean, 1964, Microorganismes planctoniques (Hystrichosphères) dans le Dévonien du Massif armoricain: Soc. géol. France Compte rendu, no. 11, p. 239-242.

de Witt, Wallace, Jr., 1951, Stratigraphy of the Berea sandstone and associated rocks in northeastern Ohio and northwestern Pennsylvania: Geol. Soc. Anıerica Bull., v. 62, p. 1347-1370.

Dijkstra, S. J., 1946, Eine monographische Bearbeitung des karbonischen Megasporen (allgemeiner Teil, p. 7-23, with P. H. van Vierssen Trip) : Geologische Stichting, Mededeelingen, ser. $\mathrm{C}-3-1$. no. 1 , p. 1-101.

1950, Carboniferous megaspores in Tertiary and Quaternary deposits of S. E. England: Annals and Mag. Nat. History, ser. 12 , v. 3, p. 865-877.

- 1952, The stratigraphical value of megaspores: $3^{\text {eme }}$ Congrès pour lavancement des études de stratigraphie carbonifère (195̃1), Compte rendu, v. 1, p. 163-168.

Ehlers, G. M., Stumm, E. C., and Kesling, R. V., 1951, Devonian rocks of southeastern Michigan and northwestern ohio: Geol. Soc. America Field Guide, November, $40 \mathrm{p}$.

Eisenack, Alfred, 1931. Nene Mikrofossilien des baltischen Silurs, 1: Palaeont. Zeitschr., v. 13, no. 1-2, p. 74-118.

1938. Hystrichosphaerideen und verwandte Formen im baltischen Silur: Zeitschr. Geschiebeforsch., v. 14, no. 1, p. 1-30.

1944, Über einige pflanzliche Funde in Geschieben, nebst Bemerkungen zum Hystrichosphaerideen-Problem: Zeitschr. Geschiebeforschung und Flachlandsgeologie, v. 19, no. 2, p. 103-124.

—_ 1951, Über Hystrichosphaerideen und andere Kleinformen aus baltischem Silur und Kambrium: Senckenbergiana, v. 32 , no. $1 / 4$, p. $187-204$.

1954, Mikrofossilien aus Phosphoriten des samländischen Unteroligozäns und über die Einheitlichkeit der Hystrichosphaerideen: Palaeontographica, v. 105, Abt. A, Lief 3-6, p. 49-95. 
Erdtman, Gunnar, 1943, An introduction to pollen analysis: Waltham, Massachusetts, Chronica Botanica Co. $239 \mathrm{p}$.

- 1947, Suggestions for the classification of fosssil and recent pollen grains and spores: Svensk bot. tidskr., v. 41, no. 1, p. 104-114.

- 1952a, On pollen and spore terminology : Palaeobotanist, v. 1 [Birbal Sahni Memorial Volume], p. 169-176.

- 1952b, Pollen morphology and plant taxonomy-Angiosperms: Waltham, Massachusetts, Chronica Botanica Co., 539 p.

- 1954, On pollen grains and dinoflagellate cysts in the Firth of Gullmarn, southwestern Sweden: Botaniska Notiser, Häfte 2 [p. 103-111 in Grana Palynologica, v. 1, no. 1].

- [ed.], 1955, Literature on palynology. 18: Geol. fören. Stockholm Förh., v. 77, no. 1, p. 71-113.

Faegri, Knut, and Iversen, Johs., 1950, Textbook of modern pollen analysis ; Copenhagen, Ejnar Munksgaard, 168 p.

Felix, C. J., 1954, Some American arborescent lycopod fructifications: Annals of Missouri Bot. Garden, v. 41, no. 4, p. 351-394.

Fisher, D. W., 1953, A microflora in the Maplewood and Neahga shales: Buffalo Soc. Nat. Sci. Bull., v. 21, no. 2, p. 13-18.

Frey-Wyssling, Albert, 1953, Submicroscopic morphology of protoplasm [2d English ed.] : Amsterdam-Houston-LondonNew York, Elsevier Publishing Co., 411 p.

Gignoux, Maurice, 1950, Géologie stratigraphique [4th ed.]: Paris, Masson et $\mathrm{C}^{\mathrm{ie}}$, $735 \mathrm{p}$.

Glaessner, M. F., 1945, Principles of micropalaeontology : New York, John Wiley \& Sons, Inc., 296 p.

Guennel, G. K., 1954, An interesting megaspore species found in Indiana Block coal: Butler Univ. Bot. Studies, v. 11, p. $169-177$.

Hartung, Wolfgang, 1933, Die Sporenverhältnisse der Calamariaceen: Preuss. Geol. Landesenstalt, Abh., Inst. Paläobot. u. Petrog. d. Brennsteine Arb., v. 3, no. 1, p. 95-149.

Hass, W. H., 1956, Age and correlation of the Chattanooga shale and the Maury formation: U.S. Geol. Survey Prof. Paper $286,47 \mathrm{p}$.

Høeg, O. A., 1937, The Devonian floras and their bearing upon the origin of vascular plants : Bot. Review, v. 3, p. 563-592. 1942, The Downtonian and Devonian flora of Spitzbergen : Norges geol. undersökelse, Skr. no. 83, 228 p.

Hofmeister, Wilhelm, 1851, Vergleichende Untersuchungen der Keimung, Entfaltung, und Fruchtbildung hoher Kryptogamen und der Samenbildung der Coniferen [English translation by F. Curry, 1862, Ray Soc. Pub. no. 22, London] : Leipzig, $179 \mathrm{p}$.

Hoffmeister, W. S., and Staplin, F. L., 1955, Additions and corrections to "Geologic range of Paleozoic plant spores in North America": Micropaleontology, v. 1, no. 4, p. 381-382.

Hoffmeister, W. S., Staplin, F. L., and Malloy, R. E., 1955a, Geologic range of Paleozoic plant spores in North America : Micropaleontology, v. 1, no. 1, p. 9-27.

- 1955b, Mississippian plant spores from the Hardinsburg formation of Illinois and Kentucky: Jour. Paleontology, v. 29, no. 3, p. 372-399.

Hoskins, J. H., and Abbott, M. L., 1956, Selaginellites crassicinctus, a new species from the Desmoinesian series of Kansas: Am. Jour. Botany, v. 43, no. 1, p. 36-46.

Hoskins, J. H., and Cross, A. T., 1943, Monograph of the Paleozoic cone genus Bowmanites (Sphenophyllales): Am. Midland Naturalist, v. 30, no. 1, p. 113-163.
1951, The structure and classification of four plants from the New Albany shale: Am. Midland Naturalist, v. 46, no. 3, p. $684-716$.

1952, The petrifaction flora of the Devonian-Mississippian black shale: Palaeobotanist, v. 1 [Birbal Sahni Memorial Volume], p. 215-238.

Hough, J. L., 1934, Redeposition of microscopic Devonian plant fossils : Jour. Geology, v. 42, no. 6, p. 646-648.

Hyde, J. E., 1912, The geological history of Fairfield County [Ohio], p. 203-223, in Miller, C. C., History of Fairfield County and representative citizens: Chicago, Illinois, Richmond-Arnold Pub. Co.

1915, Stratigraphy of the Waverly formations of central and southern Ohio: Jour. Geology, v. 23, no. 7, p. 655-682, no. 8 , p. $757-779$.

- [Marple, M. F., ed.], 1953, Mississippian formations of central and southern Ohio: Ohio Geol. Survey Bull. 51, $355 \mathrm{p}$.

Ibrahim, A. C., 1932, Beschreibung von Sporenformen aus Flöz Ägir; in Potonié, Robert, Sporenformen aus den Flözen Ägir und Bismarck des Ruhrgebietes: Neues Jahrb., Beilage-Band 67, Abt. B. p. 447-449.

—_ 1933, Sporenformen des Aegirhorizonts des RuhrReviers: Dissertation, Berlin; privately pub. by Konrad Triltsch, Wurzburg, $47 \mathrm{p}$.

Johnson, H. A., and Thomas, B. W., 1884, Report on the committee of the microscopic organisms in the bowlder clays of Chicago and vicinity: Chicago Acad. Sci. Bull., v. 1, no. 4, p. $35-40$.

Kidston, Robert, and Lang, W. H., 1924, On the presence of tetrads of resistant spores in the tissue of Sporocarpon furcatum Dawson from the Upper Devonian of America: Royal Soc. Edinburgh Trans., v. 53 pt. 3, no. 28, p. 597-601.

Klumpp, Barbara, 1953, Beitrag zur Kenntnis der Mikrofossilien des Mittleren und Oberen Eozän : Palaeontographica, v. 103, Abt. A, Lief. 5-6, p. 377-406.

Knox, E. M., 1939, The spores of Bryophyta compared with those of Carboniferous age: Bot. Soc. Edinburgh, Trans. and Proc., v. 32 , pt. 4, p. $477-487$.

- 1948, The microspores in coals of the Limestone Coal Group in Scotland: Inst. Min. Eng. Trans., v. 107, pt. 3, p. 155-163.

Kosanke, R. M., 1950, Pennsylvanian spores of Illinois and their use in correlation: Illinois Geol. Survey Bull. 74, 128 p. 1955, Stratigraphic distribution of Pennsylvanian spores [abs.] : Jour. Sedimentary Petrology, v. 25, no. 2, p. 135.

Kräusel, Richard, 1941, Die Sporokarpien Dawsons, eine neue Thallophytenklasse des Devons: Palaeontographica, v. 86, Abt. B. p. 113-135.

Kräusel, Richard, and Weyland, Hermann, 1929, Beiträge zur Kenntnis der Devonflora 3: Abh. Senck, Nat. Gesell., v. 41 , Lief. 7 , p. $315-360$.

1937, Pflanzenreste aus den Devon. 10 Zwei Pflanzenfunde in Oberdevon der Eifel: Senckenbergiana, v. 19, no. 5/6, p. 338-355.

- 1941, Pflanzenreste aus dem Devon. von Nord-Amerika : Palaeontographica, v. 86, Abt. B. p. 1-78.

Kuyl O. S., Muller, Jan., and Waterbolk, H. Th., 1955, The application of palynology to oil geology with reference to western Venezuela: Geologie en mijnbouw, no. 3, new ser., จ. 17, p. $49-76$. 
Laird, H. C., 1935, The nature and origin of chert in the Lockport and Onondaga formations of Ontario: Royal Canadian Inst. Trans., no. 44, v. 20, pt. 2, p. 231-304.

Lamborn, R. E., 1954, Geology of Coshocton County : Ohio Geol. Survey Bull. 53, $245 \mathrm{p}$.

Lang, W. H., 1925, Contributions to the study of the Old Red Sandstone flora of Scotland: Trans. Royal Soc. Edinburgh, v. 54 , pt. 2 , no. 2 , p. $253-279$.

- 1945, Pachytheca and some anomalous early plants (Prototaxites, Nematothallus, Parka, Foerstia, Orvillea n.g.) : Linnean Soc. London Jour. Botany v. 52, p. 535-552.

Loose, Friederich, 1934, Sporenformen aus dem Flöz Bismarck des Ruhrgebietes: Preuss. Geol. Landesanstalt, Abh., Inst. Paläobot. u. Petrog. d. Brennsteine, Arb., v. 4, p. 127-164.

Lowenstam, H. A., 1948, Biostratigraphic studies of the Niagaran interreef formations in northeastern Illinois: Illinois State Mus. Sci. Paper, v. 4, p. 1-146.

Luber, A. A. and Waltz, I. E., 1938, Classification and stratigraphic value of spores of some Carboniferous coal deposits in the U.S.S.R.: Cent. Geol. and Prosp. Inst. Trans., fasc. 105 , p. $1-43$.

McGerrigle, H. W., 1950, The geology of Eastern Gaspé: Quebec Dept. Mines, Geol. Rept. 35, 168 p.

Malott, C. A., 1919, The "American Bottoms" region of eastern Greene County, Indiana-A type unit in southern Indiana physiography: Indiana Univ. Studies, v. 6, no, 40, 61 p.

Mamay, S. H., 1954, Two new plant genera of Pennsylvanian age from Kansas coal balls : U.S. Geol. Survey Prof. Paper 254-D, p. 81-95.

Miner, E. L., 1932, Megaspores ascribed to Selaginellites from the Upper Cretaceous coals of western Greenland : Washington Acad. Sci. Jour., v. 22, no. 18-19, p. 497-506.

1935, Paleobotanical examination of Cretaceous and Tertiary coals 1. Cretaceous coals from Greenland: Am. Midland Naturalist, v. 16, p. 585-606.

Moore, R. C., 1937, Comparison of the Carboniferous and early Permian rocks of North America and Europe: $2^{\mathrm{a} m e}$ Congrès pour l'avancement des études de stratigraphie carbonifère [1935], Compte rendu, v. 2, p. 641-676.

Morris, John, 1840, description of plate 37 , in Prestwich, Joseph. On the geology of Coalbrook Dale: Geol. Soc. London, Trans. 2, ser. 2, v. 5. p. $413-495$, pls. 35-41.

Naumova, S. N., 1938, Microspores from the coals of the Moscow basin [Latin diagnosis, English summary], p. 21-31, in Petrography of coals and limestones of the Moscow basinSymposium: Trans. All-Union Sci. Research Inst. Econ. Mineralogy, fasc. 119.

1939, Spores and pollen of the coals of the U.S.S.R. : Internat. Geol. Congress, 17th Session, 1937, U.S.S.R., v. 1, p. 353-364.

1953, Sporovo-pyltsevye kompleksy verkhnego devona russkoy platformy i ikh znachenie dlya stratigrafii [in Russian] : Trudy Inst. Geol. Nauk AN U.S.S.R., vesha 143 (Geol. ser. no. 60), 203 p.

Newton, E. T., 1875, On "Tasmanite" and Australian "white coal"; Geol. Mag., ser. 2, v. 2, no. 8, p. 337-342.

Nikitin, P. A., 1934, Fossil plants of the Petino horizon of the Devonian of the Voronezh region. 1. Kryshtofovichia Africani nov. gen. et sp. [diag, and summary in English] : Akad. Sci. U.S.S.R. Bull. (Izvestiya Akademii Nauk, Otdelenie matematicheskikh i yestesvennykh nauk), ser. 7-A, pt. 2, no. 2, p. 1079-1091.
Norem, W. L., 1953, Separation of spores and pollen from siliceous rocks: Jour. Paleontology, v. 27, no. 6, p. 881-883.

- 1955, Tertiary spores and pollen related to paleoecology and stratigraphy of California [abs.] : Jour. Sedimentary Petrology, v. 25, no. 2, p. 136-137.

1956, An improved method for separating fossil spores and pollen from siliceous rocks: Jour. Paleontology, v. 30, no. 5, p. $1258-1260$.

Nowak, Jan, and Zerndt, Jan, 1936, Zur Tektonik des östichsten Teils des Polnischen Steinkohlenbeckens: Acad. polonaise sci. Bull. internat., A, p. 56-73.

Pepper, J. F., de Witt, Wallace, Jr., and Demarest, D. F., 1954, Geology of the Bedford shale and Berea sandstone in the Appalachian Basin: U.S. Geol. Survey Prof. Paper 259, $111 \mathrm{p}$.

Phemister, James, 1948, British Regional Geology, Scotland; the Northern Highlands [2d ed.] : Edinburgh, His Majesty's Stationery Office, $94 \mathrm{p}$.

Potonié, Robert, 1952, Zur Morphologie and morphologischen Nomenklatur der Sporites H. Potonié 1893: Palaeont. Zeitschr., v. 25, no. 3-4, p. 143-154.

1954, Stellung der paläozoischen Sporengattungen in natürlichen System: Palaeont. Zeitschr., v. 28, no. 3-4, p. 103-139.

Potonié, Robert, and Kremp, Gerhard, 1954, Die Gattungen der paläozischen Sporae dispersae und ihre Stratigraphie: Geol. Jahrb., v. 69, p. 111-194.

Prosser, C. S., 1912, The Devonian and Mississippian formations of northeastern Ohio: Ohio Geol. Survey Bull. 15, 4 th ser., v. 11, p. 327-882.

Radforth, N. W., 1938, An analysis and comparison of the structural features of Dactylotheca plumosa Artis sp. and Senftenbergia ophiodermatica Goeppert sp.: Royal Soc. Edinburg Trans., v. 59, pt. 2, no. 14, 1937-1938, p. 385-396.

Radforth, N. W., and McGregor, D. C., 1954, Some plant microfossils important to pre-Carboniferous stratigraphy and contributing to our knowledge of the early floras: Canadian Jour. Botany, v. 32, p. 601-621.

Raistrick, Arthur, 1934, The correlation of coal-seams by microspore content, pt. 1-The seams of Northumberland: Inst. Min. Eng. Trans., v. 88, no. 3, p. 142-153.

1938, The microspore content of some Lower Carboniferous coals: Leeds Geol. Assoc. Trans., v. 5, no. 4, p. 221-226.

Raistrick, Arthur, and Simpson, J. B., 1933, The microspores of some Northumberland coals, and their use in correlation of coal seams: Inst. Min. Eng. Trans., v. 85, no. 4, p. 225-235.

Read, C. B., 1955, Floras of the Pocono formation and Price sandstone in parts of Pennsylvania, Maryland, West Virginia, and Virginia: U.S. Geol. Survey Prof. Paper 263, 32 p.

Read, C. B., and Campbell, Guy, 1939, Preliminary account of the New Albany shale flora: Am. Midland Naturalist, v. 21 , no. 2 , p. 435-453.

Reeve, R. M., 1935, The spores of the genus Selaginella in North America and northeastern United States: Rhodora, v. 37, p. $341-344$.

Reinsch, P. F., 1884, Micro-Palaeophytologia formationis carboniferae; v. 1, Continens Trileteas et Stelideas, vii, 80 p., v. 2, Continens Discieas, Sphaerocladiteas, etc., p. 1-54: Erlangae, Germania, Theo. Krische. 
Rotai, A. P., 1939, Le carbonifère inferieur du Bassin Donetz et la position du Namurien dans le système carbonifère: Internat. Geol. Congress, 17th Session, 1937, U.S.S.R., v. 1, p. $461-474$.

Sahni, Birbal [ed.], 1948, Palaeobotany in India-6: Jour. Indian Bot. Soc., v. 26, no. 4, p. 241-273.

Sanford, J. T., 1933, Clinton of western New York [abs.] : Geol. Soc. America Bull., v. 44, p. 194.

1935, The "Clinton" in western New York: Jour Geology, v. 43 , no. 2 , p. $169-183$.

Schemel, M. P., 1950, Carboniferous plant spores from Daggett County, Utah: Jour. Paleontology, v. 24, no. 2, p. 232-244.

Schmidt, W. J., 1937, Doppelbrechung und Feinbau der Eischale von Ascaris megalocephala: Zeitschr. f. Zellforschung u. mikr. Anatomie, v. 25, p. 181-203.

Schopf, J. M., 1938, Spores from the Herrin (No.6) coal bed in Illinois: Illinois Geol. Survey Rept. Inv. 50, $73 \mathrm{p}$.

- 1941, Contributions to Pennsylvanian paleobotany, Mazocarpon oedipternum, sp. nov. and sigillarian relationships : Illinois Geol. Survey Rept. Inv. 75, 53 p.

—_ 1957, "Spores" and problematic plants commonly regarded as marine, in Ladd, H. S. [ed.], Treatise on marine ecology and paleoecology-v. 2, Paleoecology: Geol. Soc. America Mem. 67, p. 709-718.

Schopf, J. M., Wilson, L. R., and Bentall, Ray, 1944, An annotated synopsis of Paleozoic fossil spores and the definition of generic groups: Illinois Geol. Survey Rept. Inv. 91, $72 \mathrm{p}$.

Selling, O. H., 1944, Studies in recent and fossil species of Schizaea, with particular reference to their spore characters : Meddel. frän Göteborgs Bot. Trädg. 16, 112 p.

Shvetzov, M. S., and Yablokov, V. S. [eds.], 1937, The Moscow coal basin: Internat. Geol. Congress, 17th Session U.S.S.R., $55 \mathrm{p}$.

Siler, M. B., 1934, Development of spore walls in Sphaerocarpon donnellii: Bot. Gazette, v. 95, no. 4, p. 563-591.

Sitholey, R. V. [ed.], 1950, Palaeobotany in India-7: Jour. Indian Bot. Soc., v. 29, no. 1, p. 1-46.

Smith, G. M., 1938, Cryptogamic botany [1st ed.]: New York, MeGraw-Hill Book Co., Inc., 545 p.

Somers, Grace, 1952, A preliminary study of the fossil spore content of the Lower Jubilee seam : Nova Scotia Research Foundation, Halifax, N.S., Canada, 30 p.

Sommer, F. W., 1953, Os esporomorfos do Folhelho de Barreirinha: Brazil, Div. Geol. Mineralogia, Bol. 140, p. 1-49.

Stauffer, C. R., 1944, The geological section at the limestone mine, Barberton, Ohio: Am. Jour. Sci., v. 242, p. 251-271.

Stauffer, C. R., Hubbard, G. D, and Bownocker, J. A., 1911, Geology of the Columbus quadrangle: Ohio Geol. Survey Bull. 14, 4th ser., v. 11, p. 193-319.

Stewart, G. A., 1955, Age relations of the Middle Devonian limestones in Ohio: Ohio Jour. Sci., v. 55, no. 3, p. 147-181.

Thomson, P. W., 1940, Beitrag zur Kenntnis der fossilen Flora des Mitteldevons in Estland: Tartu Ülikooli, Loodus. Seltsi Aruanded, v. 45, no. 1-4, p. 195-216.

- 1952, Beitrag zur Kenntnis der Sporomorphenflora im Unter und Mitteldevon: Palaeont. Zeitschr., v. 25, no. 3-4, p. $155-159$.

Timm, R. W., 1950, Chemical composition of the vitelline membrane of Ascaris lumbricoides var. suis: Science, v. 112, no. 2902 , p. $167-168$.
Tippo, Oswald, 1942, A modern classification of the Plant Kingdom : Chronica Botanica, v. 7, p. 203-206.

Traverse, Alfred, 1955, Pollen analysis of the Brandon lignite of Vermont: U.S. Bur. Mines Rept. Inv. 5151, p. 1-107.

Trueman, Arthur, 1954, The coalfields of Great Britain: London, Edward Arnold Ltd., 396 p.

Weller, J. M., and others, 1948, Correlation of the Mississippian formations of North America: Geol. Soc. America Bull., v. 59, p. 91-196.

Wells, J. W., 1947, Provisional paleoecological analysis of the Devonian rocks of the Columbus region: Ohio Jour. Sci., v. 47, no. 3, p. 119-126.

Wethered, Edward, 1886, On the occurence of spores of plants in the Lower Limestone Shales of the Forest of Dean Coalfield, and in the black shales of Ohio, United States: Proc. Cotteswold Naturalist's Field Club, v. 8, p. 167-173.

Wetzel, Otto, 1933, Die in organischer Substanz erhaltenen Mikrofossilien des baltischen Kreide-Feuersteins : Palaeontographica, v. 77, p. 141-186, v. 78, Abt. A, p. 1-110.

1948, Microorganisms in chert: Micropaleontologist, v. 2 , no. 2 , p. $32-33$.

White, David, 1909, The upper Paleozoic floras, their succession and range: Jour. Geology, v. 17, no. 4, p. 320-341.

1929, Description of fossil plants found in some "mother rocks" of petroleum from northern Alaska: Am. Assoc. Petroleum Geologists Bull., v. 13, no. 7, p. 841-848.

1934, Pocono orogeny, age and climate [abs.] : Geol. Soc. America Proc., 1933, p. 34.

White, David, and Stadnichenko, Taisia, 1923, Some mother plants of petroleum in the Devonian black shales: Econ. Geology, v. 18, no. 3, p. 238-252.

White, M. C., 1862, Discovery of microscopic organisms in the siliceous nodules of the Paleozoic rocks of New York: Am. Jour. Sci. and Arts, 2d ser., v. 33, p. 385-386.

Williamson, W. C., 1880, On the organization of the fossil plants of the Coal-Measures, Pt. 10. Including an examination of the supposed Radiolarians of the Carboniferous rocks: Royal Soc. London Philos. Trans., v. 171, pt. 2, p. 493-540.

Wilson, L. R., 1934, The spores of the genus Lycopodium in the United States and Canada: Rhodora, v. 36, p. 13-19.

— 1946, The correlation of sedimentary rocks by fossil spores and pollen: Jour. Sedimentary Petrology, v. 16, no. 3, p. $110-120$.

Wilson, L. R., and Coe, E. A., 1940, Descriptions of some unassigned plant microfossils from the Des Moines Series of Iowa : Am. Midland Naturalist, v. 23, no. 1, p. 182-186.

Wilson, L. R., and Hoffmeister, W. S., 1953, Four new species of fossil Pediastrum: Am. Jour. Sci., v. 251, no. 10, p. 753-760. 1955, Morphology and geology of the Hystrichosphaerida [abs.] : Jour. Sedimentary Petrology, v. 25, no. 2, p. 137.

Winslow, J. D., White, G. W., and Webber, E. E., 1953, The water resources of Cuyahoga County, Ohio: Ohio Div. Water Bull. 26, 123 p.

Wodehouse, R. P., 1935, Pollen grains, their structure, identification, and significance in science and medicine [1st ed.] : New York, McGraw-Hill Book Co., Inc., 574 p.

Woods, R. D., 1955, Spores and pollen-a new stratigraphic tool for the oil industry [abs.] : Jour. Sedimentary Petrology, v. 25, no. 2 , p. 135.

Zalessky, M. D., 1911, Étude sur l'anatomie du Dadoxylon Tchihatcheffi Goeppert sp.: Mem. du Comité Géol. de Russe, N. S., v. 68. 
Zerndt, Jan, 1930, Megasporen aus einem Flöz in Libiaz [Stéphanien] : Acad. polonaise sci. Bull. Internat., ser. B.. p. $39-70$.

1934, Les megaspores du bassin houiller Polonais; première partie: Acad. polonaise sci., Krakow, Travaux Géol., no. $1,56 \mathrm{p}$.

1937, Les megaspores du bassin houiller Polonais; deuxième partie: Acad. polonaise sci., Krakow, Travaux Géol., no. 3, 78 p.
Zetzsche, Fritz, 1932, Kork und Cuticularsubstanzen, p. 205-239; Fossile Pflanzenstoffe, p. 293-344: in Klein, Gustav [ed.], Handbuch der Pflanzenanalyse, v. 3, 1st Hälfte, Spezielle Analyse, Teil 2, Organische Stoffe 2, Vienna, Springer.

Zetzsche, Fritz, Vicari, Hans, and Schärer, Gustav, 1931, Untersuchungen über die Membran der Sporen und Pollen, 4. 3. Fossiles Sporopollenin aus dem Tasmanit und der Moskauer Braunkohle: Helvetica Chimica Acta, v. 14, pt. 1. p. $67-78$. 


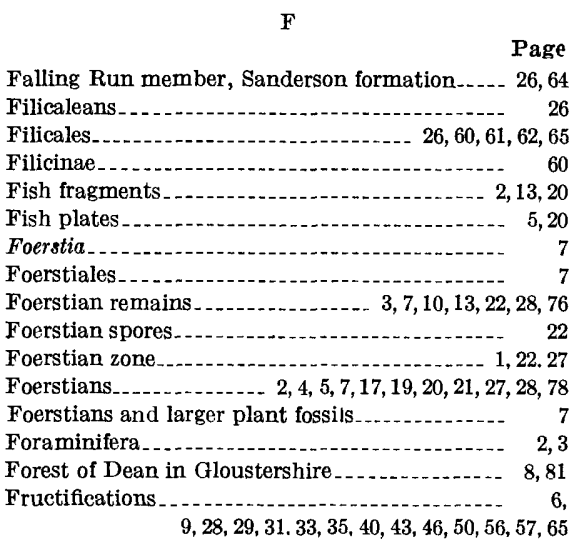

G

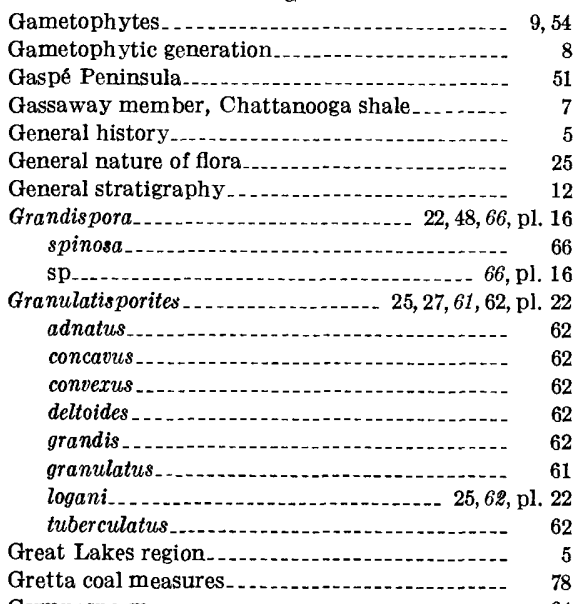

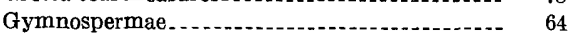

\section{Hamilton group.}

8,80

Haptotypic and emphytic characters.......- 9,79

Haptotypic, the term............................

Hardinsburg sandstone............. 7, 49, 59,66, 71, 73

Hepaticae.

Heterospory $. . . . . .5,50,54$

Holothurain sclerites. -

Huron and Cleveland members, where differentiated...... 5,12 Huron member, Ohio shale $16,17,19,20,22,54,76,77,83$

Hypnospores................ 74 Hystrichosphaeridaceae....................-. 74 Hystrichosphaeridae Hystrichosphaeridium_............ 52, 75,77, pls. 19, 22 brevispinosum

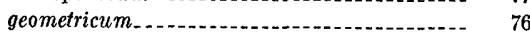
longispinosum_....._...... 23, 24, 76,77 , pls. 19, 22 ohioensis_................. 22, 23, 24,77, pls. 19, 22 trispinosum................ 22, 23, 24,75, 76, pl. 22 tubiferum Hystrichosphaerids. 2, 3, 5, 6, 8, 22, 23, 25, 27, 28, 52, 74, 75 Hystrichosphaeroid organisms.................. 8 Hystrichs.

$$
\text { I }
$$

Interpretation based on microfossils Isoetes

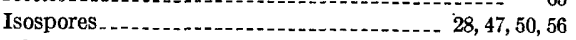
Ithaca-Enfleld formation................... 51 $\mathbf{K}$

Kettle Point bed
Kivalina basin. $\begin{array}{rr}\text { Kage } & \begin{array}{r}\text { Pagisporites } \\ 58,68\end{array} \\ \text { Kryshtofovichia } & \end{array}$ africani. $-50,51$

\section{$\mathbf{L}$}

Laboratory techniques.................... 10 Laevigatisporites. microrugosus....-...-...-...- 56

Laevigatosporites_.................... 24,65, 66, pl. 15 vulgaris_.......... 65 spp

Lagenicula $28,29,30,31,36,37$

Lang's type $G$ spores.

Leiosphaera retigera.

Leiotriletes microrugosus

Lepidocarpon.

Lepidodendrales.... 39,40

Lepidodendron

simile...

Lepidostrobus.

allantonensis.

braidwoodensis

diversus.

dubius.

gallowayi.

pulvinatus.

russelianus

$z e a$

Limestone Coal Group

Lithologic correlation .........................

Locality 1 -- $13,23,24,31,32,33,34,38,42,45,46,47,48$, $49,53,54,55,56,57,58,59,60,61,63,64,66$ $67,68,69,70,71,72,73,74,77,83,85$, pl. 1 .

Locality $2_{-} \quad 15,23,24,31,32,33,34,36,37,38,42,45,47$, $48,49,53,54,55,56,57,58,59,60,61,63,64$ $71,72,77,84$.

Locality $3 \ldots$. $15,23,24,31,33,34,38,42,45,47,48,49,54$, $56,59,64,74$

Locality $4 \ldots$ Locality 5 -- $16,24,31,32,34,37,38,39,40,41,44,52,53$, $56,57,58,61,64,65,66,67,7$

Locality 6 _. $16,22,23,25,27,30,33,37,38,42,44,45,47$, $48,49,53,54,55,56,58,60,61,64,66,67,72$, $73,76,77,83,84$

Locality 7 _. $17,25,27,30,33,35,36,38,41,42,44,45,48$, $49,52,53,54,56,58,60,61,62,64,67,68,72$, $73,74,76,77,83,84,85$.

Locality 8 - $19,22,23,25,27,30,32,34,38,42,44,45,48$, $49,53,54,56,58,61,63,64,67,71,72,73,77$, $78,83,84,85$.

Locality 9 _- 20, 23, 24, 31, 32, 34, 38, 42, 45, 47, 48, 49, 52, $53,54,55,56,58,59,63,67,69,72,73,74,76,77$

Locality $10 \ldots \ldots \ldots$................ 20, 27, 30, 52, 58, 77, 84 Lockport formation.................. 8 Logan formation $_{--} 5,7,13,18,25,27,28,29,35,36,42$,

Lophozonotriletes $43,48,49,56,60,61,62,72,73$

Lower Limestone Shales........... 8,81

Lucas County monocline........... 12

Lucas dolomite

Lycopods, arborescent herbaceous . Lycopod spores_................. 6, 26, 27, 29, 31 stems and cones .

Lycopodineae ......

Lycopodites ciliatus.

Lycopodium.

Lycopsida............. 28, 48, 52, 68

Lycopsids . . . .

Lycospora.......... 27, 39, 41, 48, pl. 18

micropapillata . . . . . . . . . 39,40

minuta.

parva.

pseudoannulata

sp. A..... 24, 40 , pl. 18

Lycospora-type spores
$\mathbf{M}$

Page

Maceration procedures

11

Macrospores.......... 2,6

Maplewood shale

Marine nektonic organisms................. 2, 27

Maxville limestone......................... 13

Mazocarpon.............. 28

Mazospora. ................................ 28

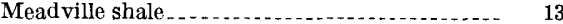

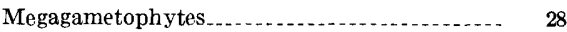

Megaspores_................. $5,17,18,22,28,47,50,56$

Meiosis _......................................... 8

Michigan Basin ............................. 12

Micrhystridium

inconspicuum

parinconspicuum

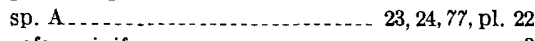

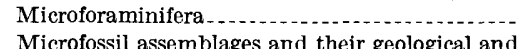

Microfossil assemblages and their geological and

Microfossil occurrence and distribution........ 21

Microreticulatisporites..................... 62

Microscopic examination and illustration....... 11

Microspores. ....................... 28, 47,50,56

Middle Devonian strata_.................. 12, 21

Mirisporites .................................. 73

Miscellaneous samples

Mississippian strata........................ 13, 24

Morphology, symmetry, orientation, and form.- 8

Moscow coal basin .................. 5, 7, 37, 58, 59

Murospora

\section{$\mathrm{N}$}

Nature of present problem

Neahga shale......... 8,76

New Albany shale........................ 26, 64

Noeggerathiales. . . .

Nomenclatural and taxonomic treatment...... 10

0

Ohio shale $8,12,13,15,17,20,21,22,24,27,30,39,43$, $44,49,50,51,52,58,64,68,72,73,76,77,83$, 84,85 .

Ohio and Chagrin shales (undifferentiated) _..-- 18 ,

Ohio shale, Huron and Cleveland members where differentiated ................ 5,12

Ohio shale, undifferentiated.............. 3,12

Old Red Sandstone of Scotland.......

$29,47,50,51,81$.

Olentangy shale $\ldots \ldots, 17,18,19,20,21,22,54,76,83,84,85$.

Oligocene blue earth

Onondaga limestone

Orangeville shale $\ldots, \ldots$

Oriskany sand........................... 18, 19

Ostracodes.................. 5, 12, 17

Ovum hispidum brevispinosum

\section{$\mathbf{P}$}

Palaeostachya decacnema................... 56 Palynological correlation

Palynological zonation .

Palynology

Pediastrum 75,77

Peridineans $\quad 74$

Perisaccus_............... 81

Pertinent plant-spore literature

Phaeophyceae.............................. 2

Phyletic patterns. 3

Phytoplankton

Pityeaceae. . .

Pityeae............. 26

Pitys brownii

Planktonic organisms 


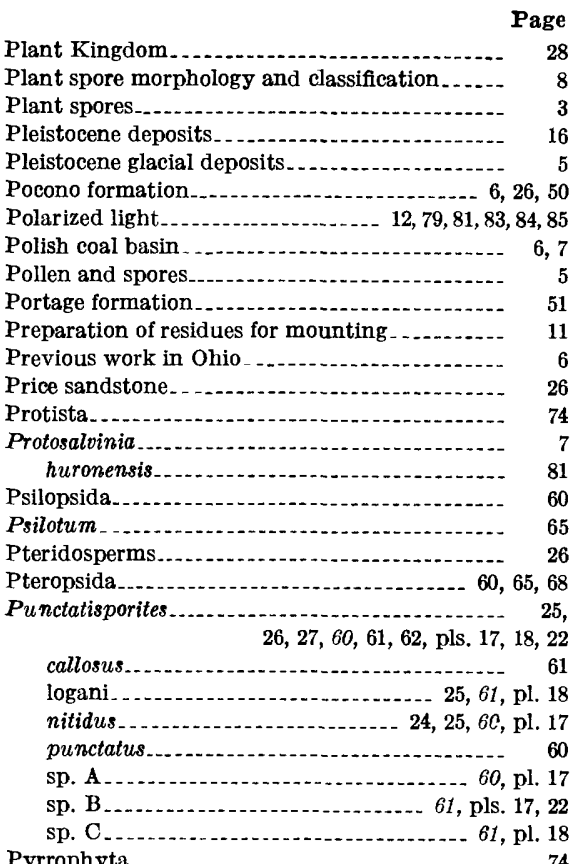

\section{Q}

Quaternary pollen studies.

\section{$\mathbf{R}$}

R. J. Dalier No. 3 well _._. . Radforthia. . . . 72 , pls. 16, 22 radiata $\ldots . . . . . . .22,23,24,25,72$, pls. 16,22

Radial symmetry of spores.................. 9 Radiolarians.

Raistrickia

crocea

59

Reticulatisporites...... 26, 27, $57,58,59,71$, pls. 14,22 crassus_........... 23, 24, 25, $58,71,73$, pls. 14,22 fimbriatus.................. 24, 25, 58,59 , pls. 14, 22 var. fimbriatus....................... 59 var. spathulatus _........... 23, 24, 59 , pls. 14, 22 muricatus............................. 59 reticulatus _............................... 57 spp $\ldots \ldots$. pl. 14 Review of megafossil evidence.............. 25

Review of previous studies............ 5

Rocky Fork.
Russian platform

Sagamore siltstone member Salina formation.

Sample examination................. 10

Sampling localities.................... 13

Scaumenac flora. ........ 51

Schopfites........................... 63,64

Sclerenchymatous nests.............. 24, 73,74, pl. 21

Sclerocelyphus ...................... 57

Scolecodonts

Secondarily deposited microfossils. .... $3,5,8,21.8385$

Seedlike structures . . .

Selaginella..... 10

Selaginellales_............................. 40,41

Selaqinellites........... 29, 40,50

suissei............................... 33,40

Setosis portes hirsutus. ...................... 34

Sharon conglomerate....................... 16

Sharpsville sandstone....................... 6,13

Sigillariaceae . . .

Sigillarians.

$26,28,30,39$

\begin{tabular}{|c|c|}
\hline $\begin{array}{l}\text { Page } \\
\end{array}$ & Page \\
\hline 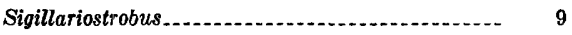 & Teträedron \\
\hline Silurian rocks of the Baltic . & Tinkers Creek \\
\hline Simozonotriletes....... 68 & Torispora securis \\
\hline 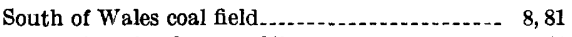 & Tracheid fragments \\
\hline Spenceris porites karczewskii.......... 46 & Tracheophyta \\
\hline Spenceris porites spores. 43,46 & 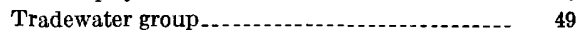 \\
\hline Spermatites & Traquairia \\
\hline elongatus... 65 & Triangulati........... \\
\hline 65 & $3,6,10,20,26,27$ \\
\hline sp_.............. & $28,29,30,32,34,37,39$, pls. $3-9,17,19$ \\
\hline Sphenophyllales............ & $30,37,38$ \\
\hline Sphenopsida & angulatus \\
\hline Sphenopsids & aries \\
\hline Sponge spicules & auritulus \\
\hline Sponges & catenulatus _.... $23,24,29,31,32,33,34,36$, pls. 5,6 \\
\hline Sporangia....... 6,8 & var. catenulatus \\
\hline Sporangites. & var. marginatus \\
\hline ngites & var. mixtus__._. $25,29,32,38,35$, pl. 7 \\
\hline alaskensis & cervicornis _. _....... 24, 29, 33, 34, 35, pls. 4,5 \\
\hline arctica. & crassiaculeatus \\
\hline huronensis & fulgens....... 39 \\
\hline granulose & glabratus \\
\hline 62 & globulus \\
\hline 62 & hirsutus........ 34 \\
\hline reticulate & horridus. \\
\hline 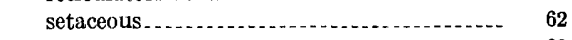 & indianensis. 30,38 \\
\hline spinose & mamillarius \\
\hline verrucose & -type spores. \\
\hline Spore mother cell (diploid) & praetextus \\
\hline Spore size variation & radiosus ... \\
\hline Spore type A & rugosus-type megaspores. \\
\hline Spore type $\mathrm{B}_{2}$ & simplex \\
\hline Spore type C....... 73, pl. 19 & var. levis \\
\hline Spore type D... 73, pl, 18 & splendidus \\
\hline Sporenine... 9 & subtilinodulatus \\
\hline Sporocarpon & triangulatus \\
\hline Sporopollenine $\ldots . . . . .$. & -type megaspores \\
\hline Stanley formation & triquetrus \\
\hline Statoblasts & variabilis \\
\hline Statospores. & $30,98,39$, pl. 19 \\
\hline Stenozonotriletes ornatissimus & $24,30,38,39,50$, pl. 7 \\
\hline Stigmarienkohle & 39, pls. $5,17,19$ \\
\hline Stratigraphic correlation & 26 \\
\hline
\end{tabular}

Stratigraphic occurrence

Stratigraphic relations and sample localitie $\begin{array}{ll}\text { Straurastrium fulcigerum.......... } & 72 \\ \end{array}$ Summary _. . . . .

Sunbury shale _..... _ $5,6,11,13,16,18,19,20,21,25,27$, $42,48,49,61,63,64,67,71,72,73$

Suprageneric classification of plants

Sylvania sandstone _.................... 16, 18, 19

Systematic descriptions $\ldots \ldots$

\section{T}

Tapetal fluid. 9

Tasmanite coal samples . . .

Tasmanite marine coal...................... 8

Tasmanites _... $24,25,26,27,28,52,75,77,78,79,81,82,83$, 85, pls. 20,21 .

avelinoi....

$80,84,85$

chicagoensis

80

derbyi.

$\begin{array}{rr}\text { derbyi } & 80 \\ \text { hartti } & 80, \ldots 1 \\ 80,84\end{array}$

huronensis mourai punctatus ........... $79,80,82,84$ roxoi_...

salustianoi _........... 80,83 sinuosus . . . . . . 21, 22, 24, 25, 81, 82, 83, 84, 85, pl. 20 sommeri................. 22, 81, 82, 84, pls. 20, 21 tapajonensis . . . . . . . . . . sp. A......... 22, 83, 85, pl. 20 sp
$\mathrm{U}$

Uncertain Class, Order, and Family

Uncertain section ........................ 38

Unidentified dermal and subdermal structures _ - $\quad 73$

Unidentified spores........................... 79

Unidentified vascular fragments . ........... 65, pl. 19

Upper Devonian of the Russian platform $\ldots . . .5$

uper Devonian strata...

Vascular cryptogamic plants.

9

Vascular fragments ........................ 22, 24 Verrucosisporites ........ 27, 60, 62, 63, pls. 17, 18, 19 depressus......... 24, 25, 63, pl. 19 triquetrus......... 63 sp. A... Vinton member, Logan formation. ........ 13, 25

Worm casts

(1)

7

Xanthidium...

tubiferum Zonales...

Zonarium, the term

Zonotriletes microalveolatus

Zygospores.

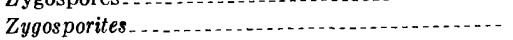

Uncertain family ......................... 39, 41 verrucosus A (1)

6
. 
PLATES 1-22 
PLATE 1

Locality 1-Chagrin shale, Cleveland member of the Ohio shale, and Bedford shale, section along north bank of Chippewa Creek, 100 feet south of State Route 82, Brecksville Reservation, Cuyahoga County, Ohio. Lettered triangles indicate position of samples macerated and studied in detail. Above the strata shown in this photograph is 36 feet of red and gray Bedford shale overlain disconformably by about 30 feet of Berea sandstone. Photograph by J. D. Winslow, U.S. Geological Survey. 


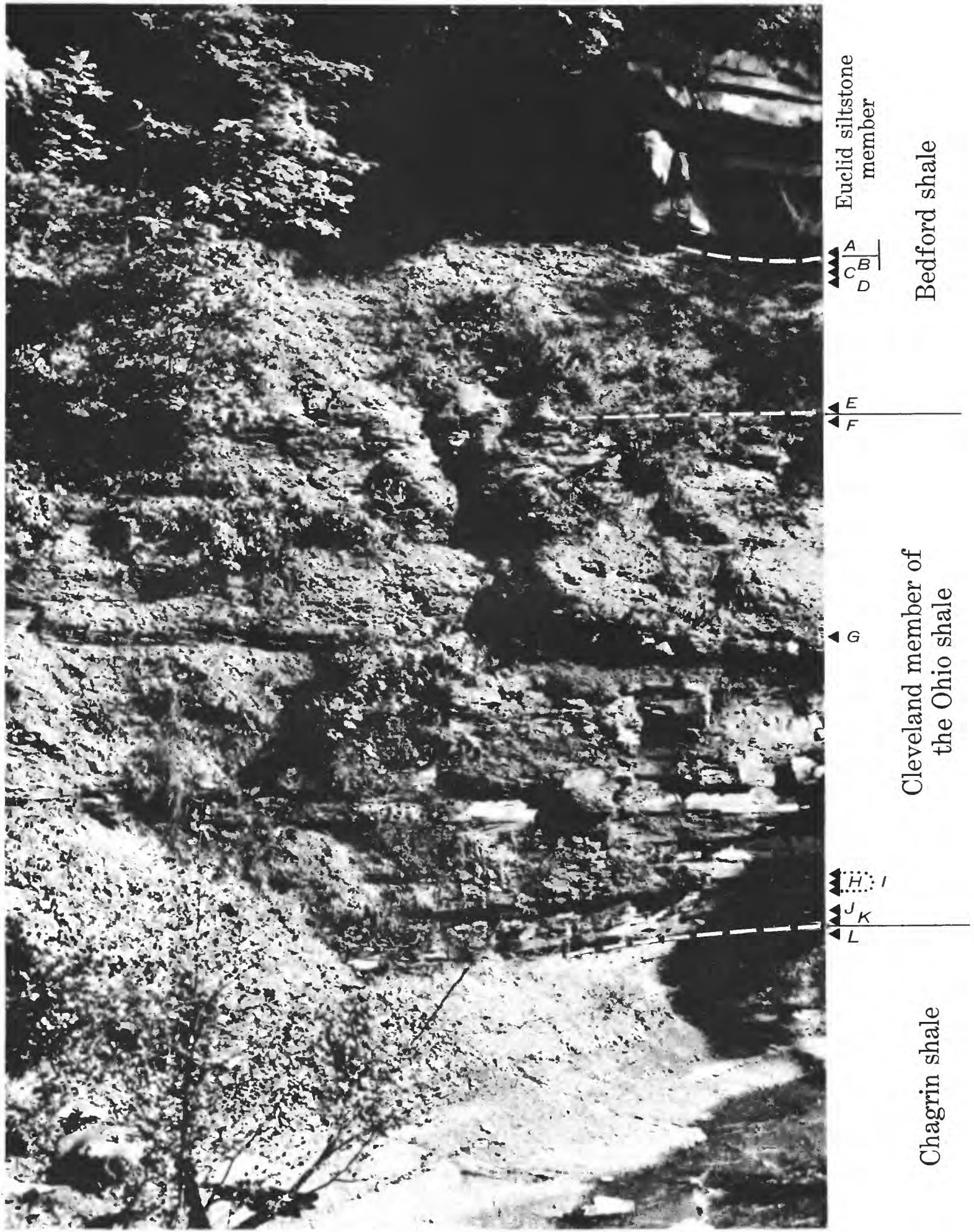

CHAGRIN, OHIO, AND BEDFORD SHALES 


\section{PLATE 2}

[All photographs by reflected light]

Figure 1. Berea sandstone; weathered specimen is broken somewhat obliquely across the bedding. Plant microfossils, including many uncompressed specimens, are abundant in the sandy matrix and in carbonaceous layers, $\times 1.7$. Sample from loc. 5, quarry 6, South Amherst, Lorain County, Ohio, colln. 1-11-14-53.

2. Bedford shale, view nearly parallel to the bedding. Note contrast of the bedding plane thickly covered with plant debris with that at lower right almost devoid of carbonaceous remains. Light area in upper left center is iron stained. Specimen photographed immersed in xylol, $\times 2.2$; millimeter scale in upper left. Specimen from loc. 2, taken 11.5 feet below the Sagamore siltstone member of the Bedford shale, Tinkers Creek, north side of Button Road, Cuyahoga County, Ohio, colln. 7-12-6-53.

2a. Part of same specimen photographed dry. Note contrast with fig. $2, \times 2.2$.

3. Bedford shale, smoothed and etched section normal to the bedding, photographed immersed in xylol, showing crossbedding. Laminae containing abundant plant remains show as thin dark bands. Note slightly contorted bedding in upper part of specimen and vertical worm(?) burrow at bottom, right of center, $\times 1.9$. Specimen from same collection as that shown in fig. 2. 

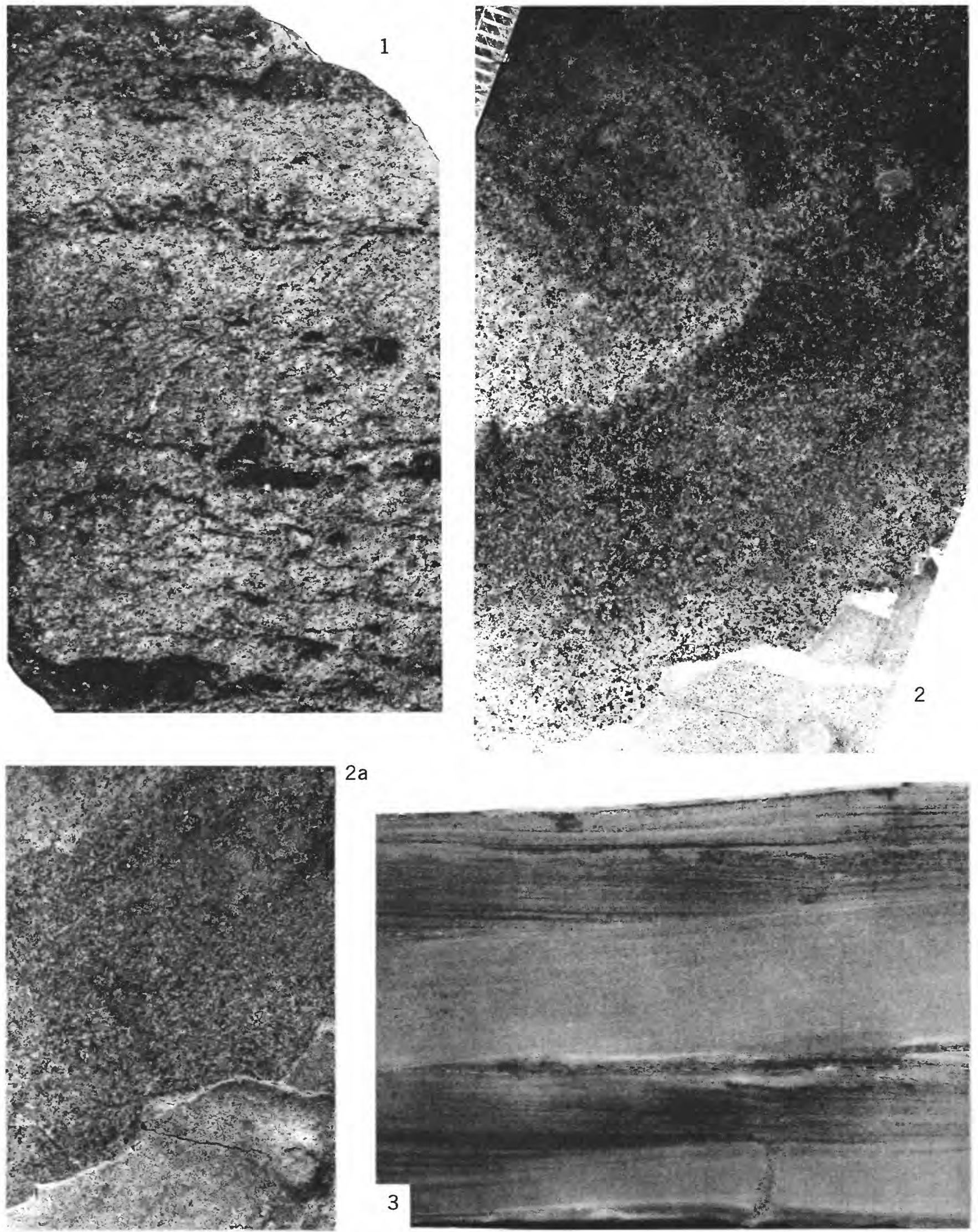


\section{PLATE 3}

[All photographs by transmitted light]

Figures 1-6. Triletes auritulus n. sp. (p. 30).

1. Holotype. Lateral compression showing auricles (au) at termini of rays. Axial length, including lips, is $1,690 \mu$. Note the smooth appearance resulting from preservation in a fine-grained matrix in contrast to the mottled appearance of spores shown in figs. 2 and 3 . See figs. 3 and 6 for scale. Bedford shale, loc. 1, maceration 40C, slide 1, colln. 4-11-1-52.

1a. Same specimen. Detail of distal spore coat shows long thin spines with expanded bases. Scale indicated.

2. One of largest specimens observed, $2,250 \mu$ in axial length. Lateral compression showing auricles (au), and apical segments split apart. Mottled appearance is caused by the impression of the sandstone matrix. Figure is a composite constructed from two prints. See figs. 3 and 6 for scale. Berea sandstone, loc. 5 , maceration 153, slide 7, colln. 1-11-14-53.

2a. Same specimen, detail of contact face and auricle. Scale indicated.

3. Specimen showing relatively high lips and prominent auricles. Scale indicated. Berea sandstone, loc. 5, maceration 153, slide 7, colln. 1-11-14-53.

3a. Typical spine, located below auricle of same specimen (note arrow), showing expanded base. See fig. la for scale.

3b. Clavate spine on distal coat of same specimen (note arrow). See fig. 1a for scale.

4. Slightly overmacerated specimen, axial length $1,825 \mu$. Two auricles are well shown. Arcuate ridge appears as narrow dark band. See figs. 3 and 6 for scale. Bedford shale, loc. 2, maceration 163, slide 1, colln. 9-12-6-53.

5. Specimen with less prominent lips; axial length $1,150 \mu$. Small spines (not visible in fig.) cover distal coat. Scale indicated. Basal part of Bedford shale, loc. 1, maceration 61-1, slide 13, colln. 5-5-23-53.

6. Specimen similar to that in fig. 5. Scale indicated. Bedford shale, loc. 2, maceration 163, slide 2, colln. 9-12$6-53$. 


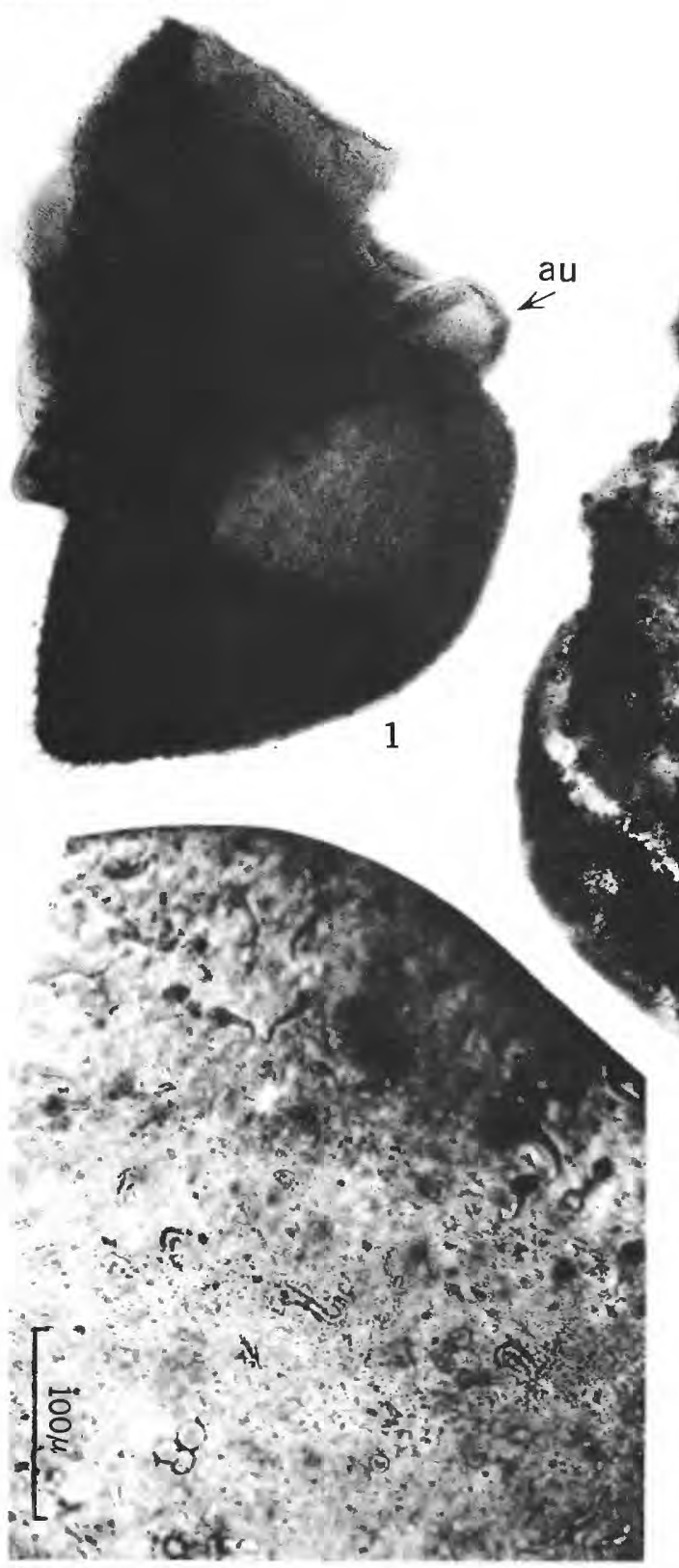

$1 \mathrm{a}$

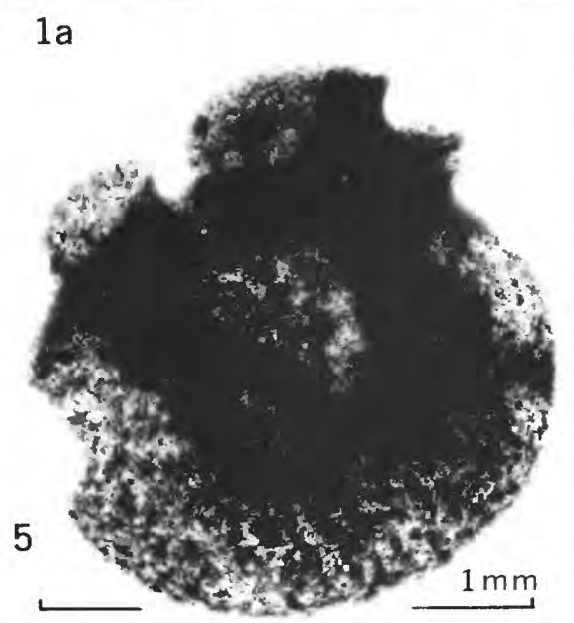

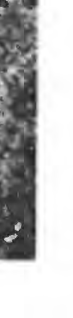
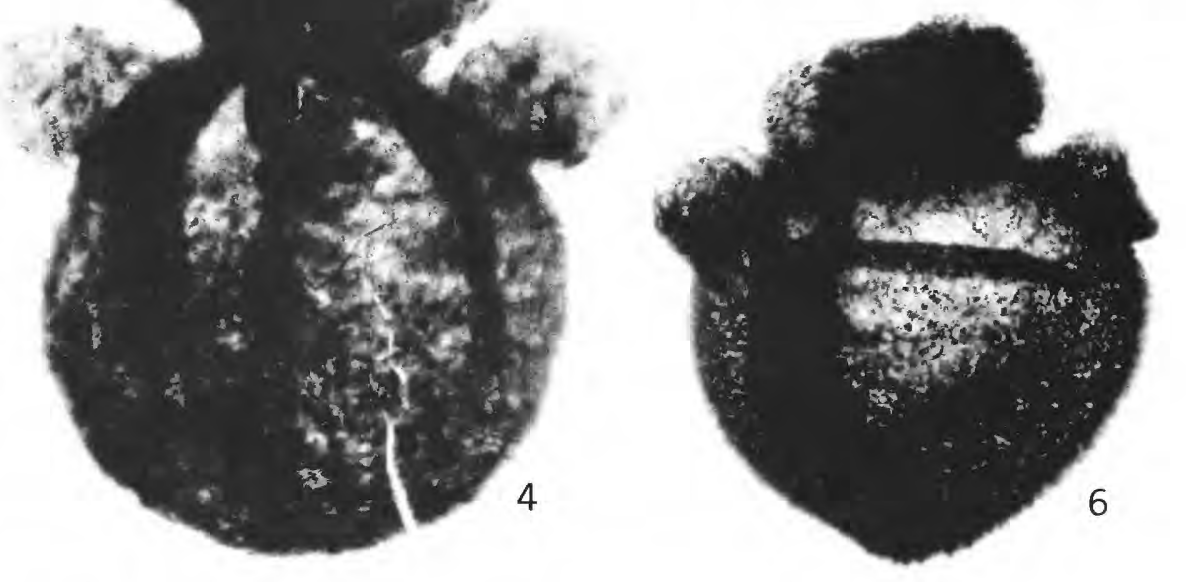

TRILETES AURITULUS N. SP. 


\section{PLATE 4}

Figures 1-2. Triletes auritulus n. sp. (p. 30).

[All photographs by transmitted light]

1. Proximal end of an overmacerated specimen (complete axial length about $1,200 \mu$ ) showing auricles and faint arcuate ridges. See fig. 5 for scale. Berea sandstone, loc. 5, maceration 153, slide 6, colln. 1-11-14-53.

1a. Same specimen, distal part, showing spines and simulated reticulations. Spore coat ranges from $28 \mu$ to $34 \mu$ in thickness. See fig. 5 for scale.

2. Specimen showing arcuate ridge and highly developed auricles, axial length $1,250 \mu$. Scale indicated. Bedford shale, loc. 2, maceration 161 , slide 5 , colln. 8-12-6-53.

3-5e. Triletes cervicornis n. sp. (p. 34).

3. Rare proximodistal compression showing outline of apical prominence (ap), about $420 \mu$ in diameter. Spore is centered over strong beam of light. See fig. 5 for scale. Bedford shale, loc. 2, maceration 161, slide 25, colln. 8-12-6-53.

3a. Same specimen showing outline of marginal spines, as photographed through a blue-green filter. See fig. 5 for scale.

4. Lateral compression showing unusually high apical prominence, about $840 \mu$ in axial length. See fig. 5 for scale. Bedford shale, loc. 2, maceration 161, slide 9, colln. 8-12-6-53.

5. Holotype. Oblique proximal view of uncompressed spore, apex (ap) showing in faint outline. Figure obtained by overlay of two photographs taken at different focal planes; specimen centered over strong beam of light. Scale indicated. Berea sandstone, loc. 5, maceration 153, slide 10, colln. 1-11-14-53.

5a. Same specimen showing apex and denser concentration of spines at end of one ray. See fig. 5 for scale.

$5 \mathrm{~b}, 5 \mathrm{c}, 5 \mathrm{~d}, 5 \mathrm{e}$. Same specimen showing details of forked spines which range from about $6 \mu$ to $11 \mu$ in width near their bases and from $50 \mu$ to $65 \mu$ in length. One termination of spine in fig. $5 \mathrm{~d}$ is broken away. Photographed through a blue-green filter. Scale indicated on fig. 5e. 


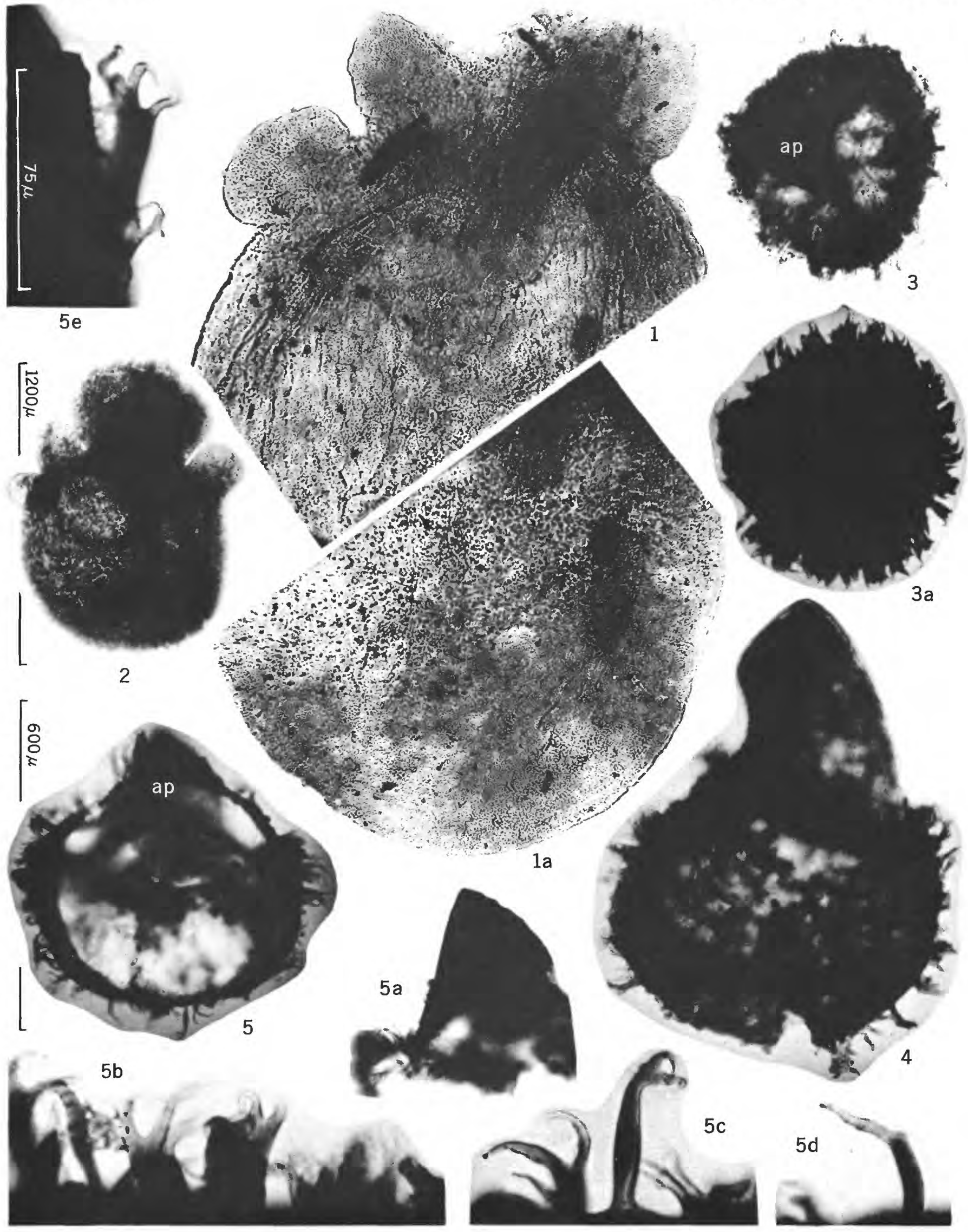

TRILETES AURITULUS N. SP. AND T. CERVICORNIS N. SP. 


\section{PLATE 5}

[All photographs by transmitted light]

Figures 1, 1a. Triletes cervicornis n. sp. (p. 34).

Bedford shale, loc. 1, maceration 40A, slide 13, colln. 4-11-1-52.

1. Lateral compression, including apical prominence, about $510 \mu$ in axial length. Specimen illustrates contrast between the sparsely ornamented contact surfaces with highly ornamented distal surface, though rather poorly preserved. See figs. 6 and 7 for scale.

1a. Same specimen showing detail of distal spines and small spinules on contact area. Scale indicated.

2-2b. Triletes sp. (p. 39).

Chagrin shale, loc. 6, maceration 44-1-A, slide 1, colln. 912-792-797.

2. One of several types of medium-sized land-plant spores from the Chagrin shale. Specimen possesses high apical structures (ap) in relation to body diameter. Coat is $14 \mu$ thick. See figs. 6 and 7 for scale.

$2 \mathrm{a}, 2 \mathrm{~b}$. Same specimen showing detail of uniformly spaced spines tapering from enlarged bases $\times 2.1 \mathrm{fg}$. 2 . Photographed through a blue-green filter.

3, 3a. Triletes sp. (p. 39)

Bedford shale, loc. 1, maceration 40B, slide 6, colln. 4-11-1-52.

3. Lateral compression of one of the smallest spores observed to possess a high apical prominence. Spines delimit contact face. Spore coat is about $4.3 \mu$ thick. Scale indicated.

3a. Same specimen, in a different plane of focus, showing distal surface and details of apex. See figs. 1 a and 3 for scale.

4. Triletes catenulatus n. sp. (p. 31).

Oblique compression, apex broken. Spore coat is set with spines in a discontinuous reticulate pattern. See figs. 6

and 7 for scale. Bedford shale, loc. 1, maceration $40 \mathrm{~A}$, slide 6, colln. 4-11-1-52.

5, 6. Triletes catenulatus? (p. 32).

5. Lateral compression, $630 \mu$ in axial length, showing extremities of trilete rays or lips extending beyond spore body. Specimen may be a denuded spore of T. catenulatus. See figs. 6 and 7 for scale. Bedford shale, loc. 1 , maceration 40A, slide 6, colln. 4-11-1-52.

6. Obliquely compressed specimen, possibly representing a completely denuded spore of T. catenulatus. Scale indicated. Bedford shale, loc. 1, maceration 40A, slide 4, colln. 4-11-1-52.

7. Triletes catenulatus var. marginatus? (p. 32).

Smaller obliquely compressed specimen showing trilete ray extending beyond margin, partly hidden by apical prominence. Specimen may represent a denuded spore of $T$. catenulatus var. marginatus. Scale indicated. Bedford shale, loc. 1, maceration 40A, slide 4, colln. 4-11-1-52.

8, 8a. Triletes catenulatus var. marginatus n. var. (p. 32).

Bedford shale, loc. 1, maceration 40A, slide 13, colln. 4-11-1-52.

8. Holotype. Obliquely compressed specimen $480 \mu$ in diameter, showing well-developed thin serrate flange and discontinuous catenulate ornamentation of distal spore coat. Rays extend out onto flange. See figs. 6 and 7 for scale.

8a. Same specimen showing detail of flange and, along upper margin of spore body, outline of low distal ornamentation. Scale indicated. 


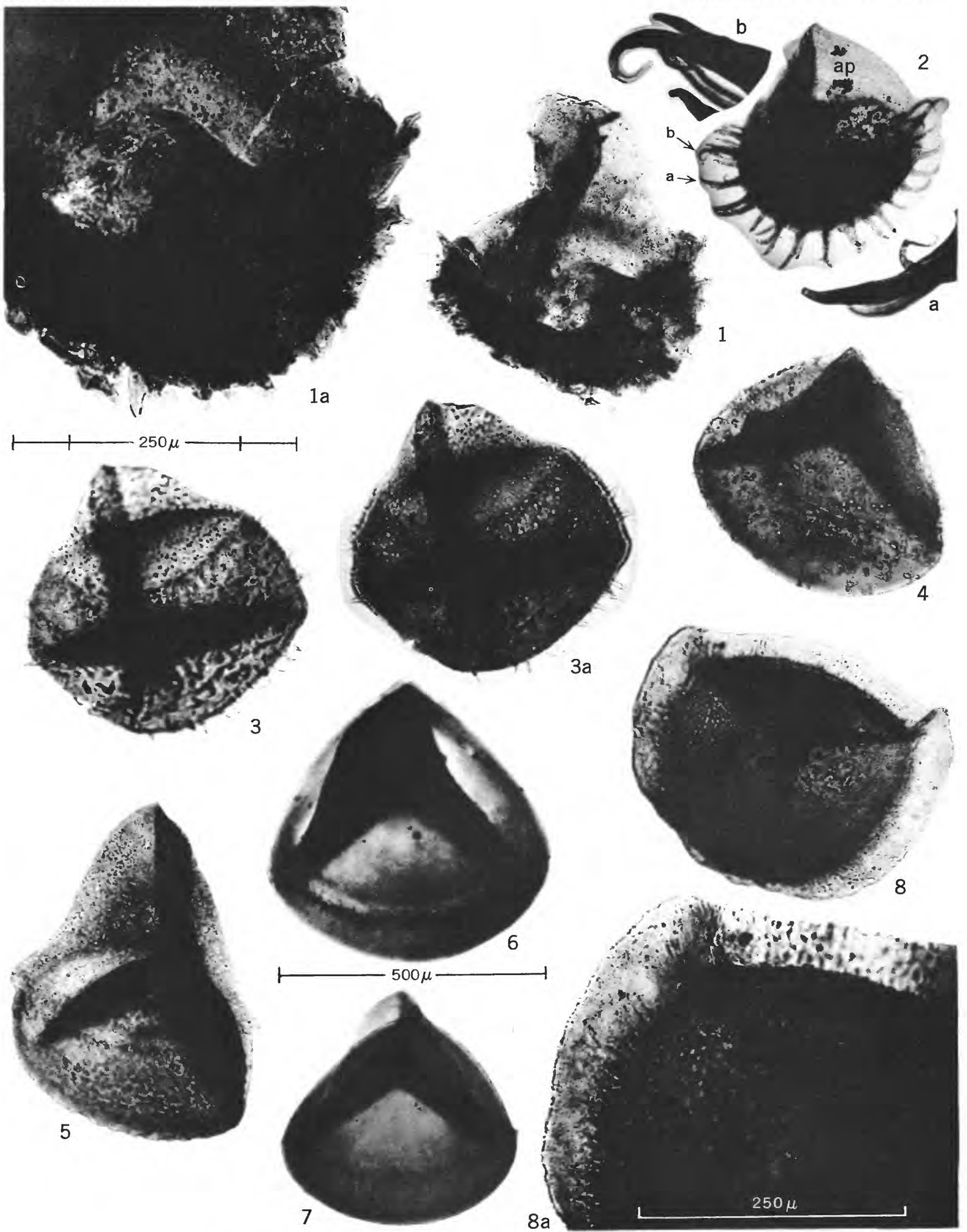

TRILETES CERVICORNIS N. SP., T. SPP., AND T. CATENULATUS N. SP. 


\section{PLATE 6}

Figures 1, 1a. Triletes catenulatus? (p. 32).

Bedford shale, loc. 2, maceration 161, slide 13, colln. 8-12-6-53.

1. Oblique compression. Trilete rays and apical prominence appear black. Note discontinuous reticulate pattern formed by rows of fused spines on distal surface. See fig. $4 \mathrm{a}$ for scale.

1a. Same specimen showing detail of fused ornamentation, about $24 \mu-30 \mu$ in length. Position of apical prominence noted (ap). See fig. 2a for scale.

2-3b. Triletes catenulatus n. sp. (p. 31).

2. Laterally compressed valve, one-third of original spore, showing high apical prominence $(250 \mu)$ and juncture of lips with contact area. See fig. 4 a for scale. Bedford shale, loc. 2, maceration 161, slide 11, colln. 8-12-6-53.

2a. Same specimen showing detail of discontinuous reticulate (chainlike) spines typically developed. Scale indicated.

3. Holotype. Oblique compression $610 \mu$ in diameter, showing discontinuous reticulate pattern in lighter area and hyperdevelopment of the catenulate spines into a flange at the weakly developed arcuate ridge. Distorted apical prominence noted (ap). See fig. 4a for scale. Bedford shale, loc. 2, maceration 161, slide 25 , colln. 8-12-6-53.

3a. Same specimen showing detail of hyperdeveloped catenulate spines. See fig. 2 a for scale.

3b. Same specimen showing detail of spines on distal surface in side view. See fig. 2 a for scale.

4-5. Triletes catenulatus var. marginatus n. var. (p. 32).

4. Proximodistal compression showing outline of distorted apical prominence and expression of trilete rays on flange. Maximum diameter of spore body is about $470 \mu$. See fig. 4 a for scale. Basal part of Bedford shale, loc. 1, maceration 61-1, slide 5, colln. 5-5-23-53.

4a. Same specimen showing details of flange, $60 \mu-85 \mu$ wide, partly torn away from body of spore. Scale indicated.

5. Detail of flange torn away from spore body. Photographed with a blue-green filter. See fig. 2a for scale. Bedford shale, loc. 2, maceration 159 , slide 4, colln. 7-12-6-53-b. 

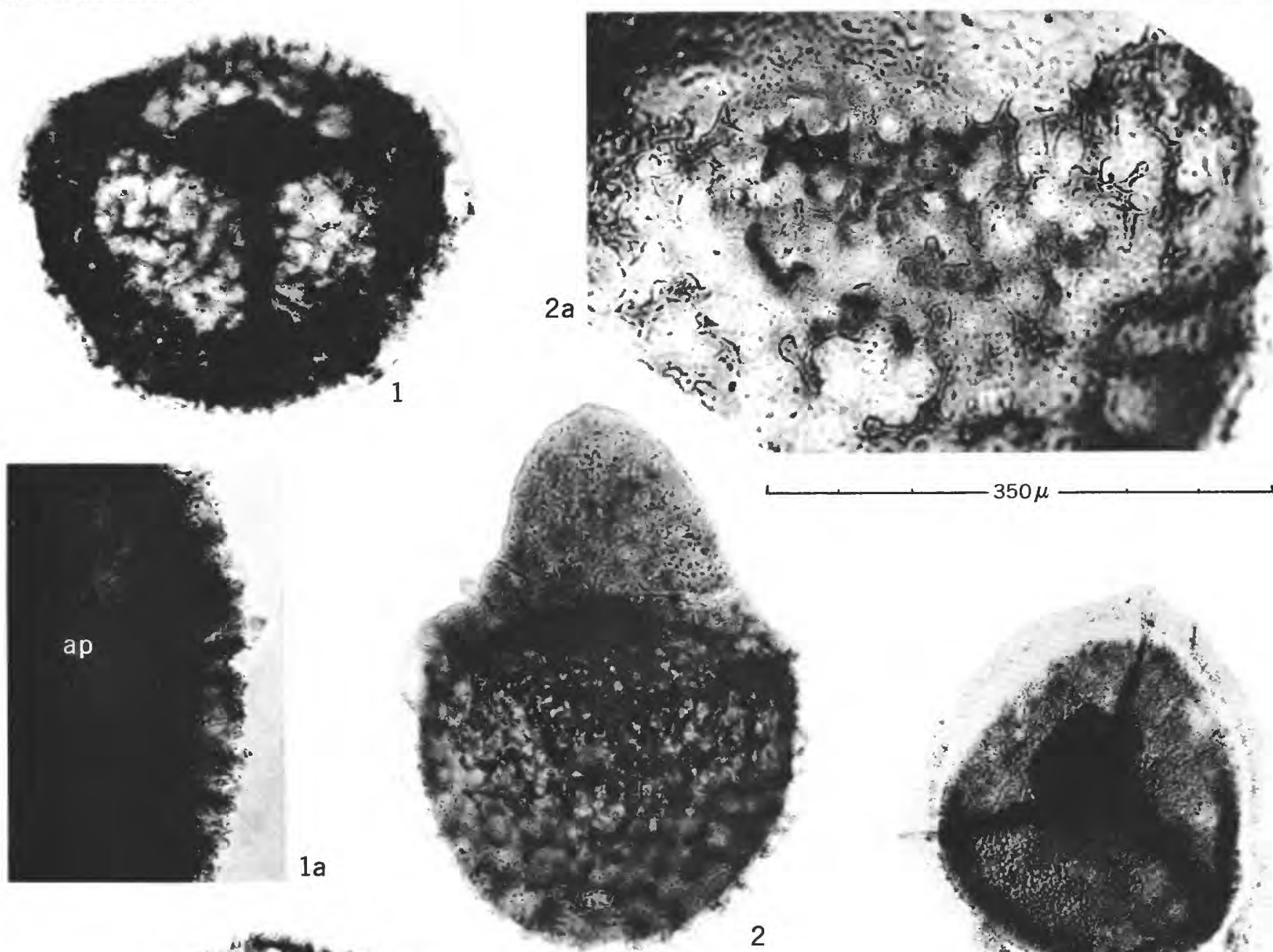

$-350 \mu$
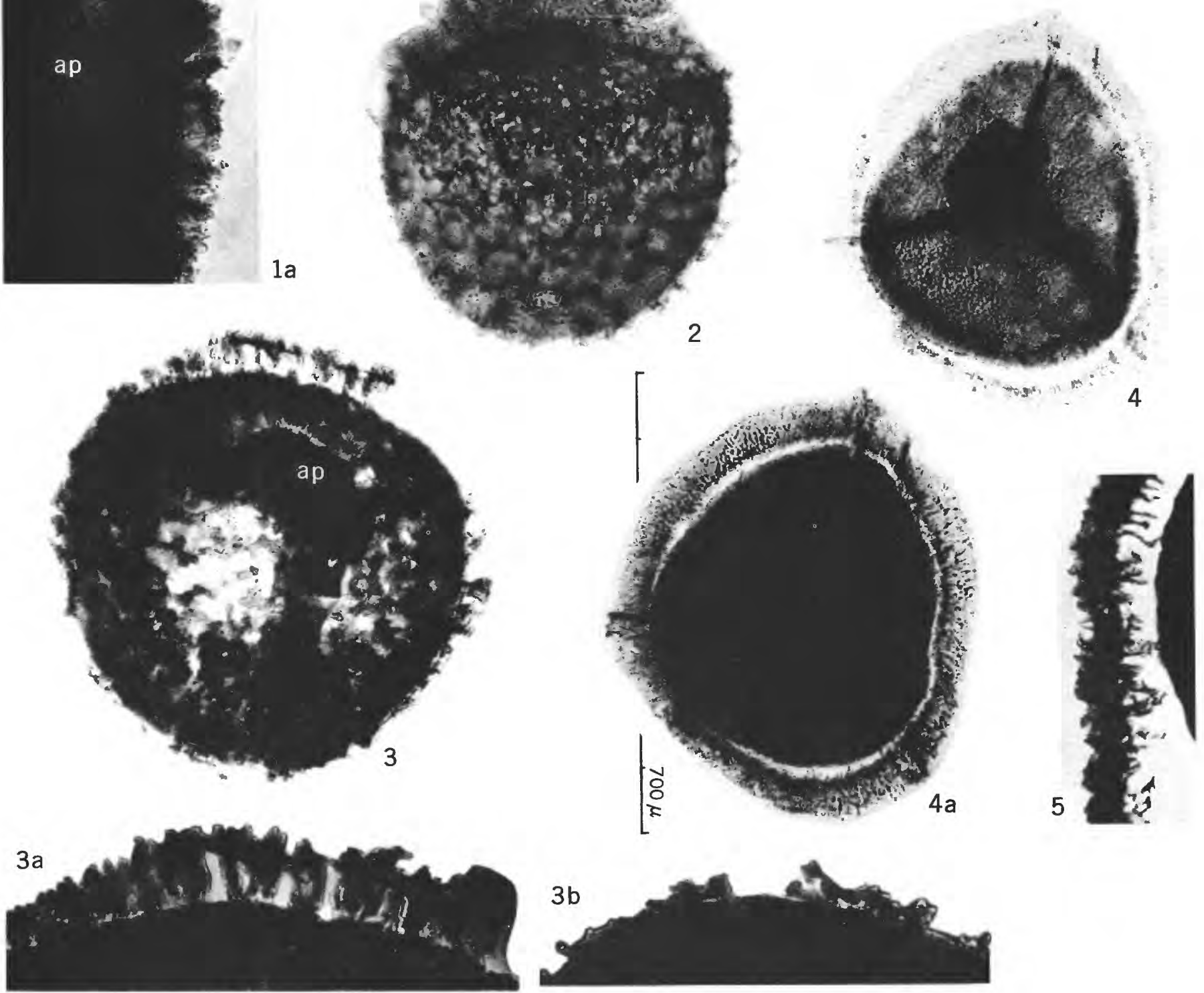


\section{PLATE 7}

Figures 1-1b. Triletes? sp. B (p. 38).

Photographed by transmitted light. Berea sandstone, loc. 5, maceration 153, slide 17, colln. 1-11-14-53.

1. Lateral compression including lips, $1055 \mu$ in axial length. See fig. 4 for scale.

1a. Same specimen showing detail of mammillate(?) spines, about $40 \mu-70 \mu$ in diameter. Mammillate spines may be abraded spine bases. Scale indicated.

1b. Same specimen showing detail of spines. Spine indicated by arrow is $70 \mu$ wide at the base and $40 \mu$ high. Note central papilla $(10 \mu \times 10 \mu)$ at tip of protuberance. See fig. 1a for scale.

2. Triletes catenulatus var. mixtus n. var. (p. 33).

Holotype. Axial length, including basally constricted apical prominence, is $630 \mu$. Specimen possesses small spines on lips and contact areas as well as distal spines $15 \mu-25 \mu$ in length. Photographed by transmitted light. See fig. 1a for scale. Cuyahoga and Black Hand formations undifferentiated, loc. 7, maceration 366, slide 2.

3, 4. Triletes variabilis n. sp. (p. 34).

Photographed by reflected light.

3. Lateral compression. Spore possesses high apical prominence slightly constricted basally. Very few of the spines are doubled or forked. See fig. 4 for scale. Logan formation, loc. 7, maceration 362, dry mount.

4. Holotype. Lateral compression is $1,380 \mu$ in axial length. Distal surface is set with basally fluted spines $100 \mu-150 \mu$ in length. Small subsidiary spines on the distal coat and smaller spines on the lips give the spore a very rough appearance. Scale indicated. Logan formation, loc. 7, maceration 361, slide 3 .

5. Triletes aries $\mathrm{n}$. sp. (p. 37).

A somewhat variant example in proximodistal compression possessing relatively small contact areas and more subdued ornamentation than is typical of the species. Photographed by reflected light. See fig. 4 for scale. Cuyahoga and Black Hand formations undifferentiated, loc. 7, maceration 366.

6, 7. Triletes triquetrus n. sp. (p. 35).

Photographed by reflected light. See fig. 4 for scale. Logan formation, loc. 7, maceration 362, slide 7 .

6. Holotype. Lateral compression possesses a highly developed apical prominence bearing a few large spinose processes. The base of the lips is above these processes. The manner of compression makes the apical prominence appear higher than it actually is. Outline of typical small triangular outgrowth at the termination of one ray is well shown.

7. One of few proximodistally compressed specimens. Apical prominence is less well developed than that shown in fig. 6, appearing even less so because of the orientation of the spore. 

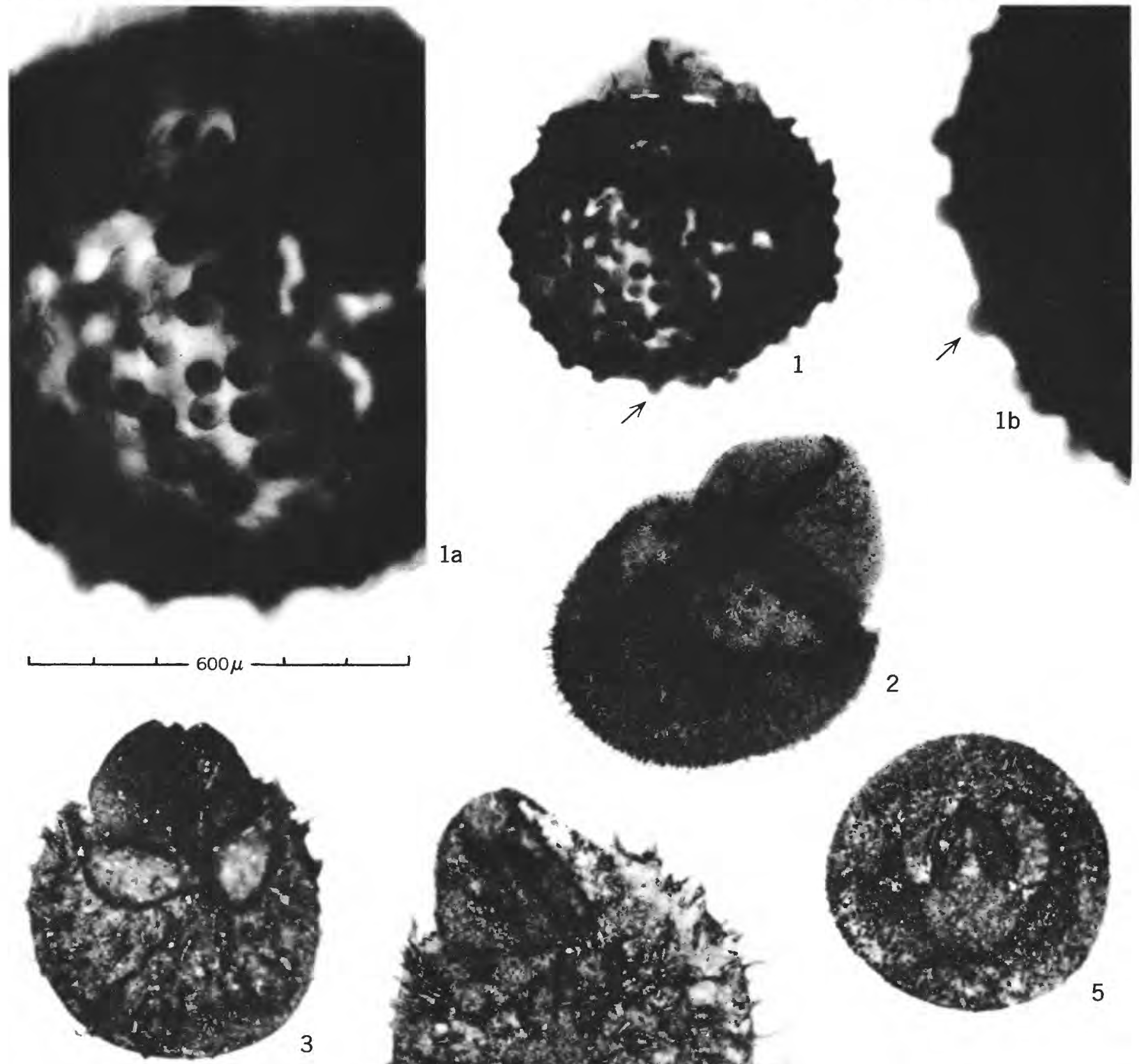

3

\section{5}
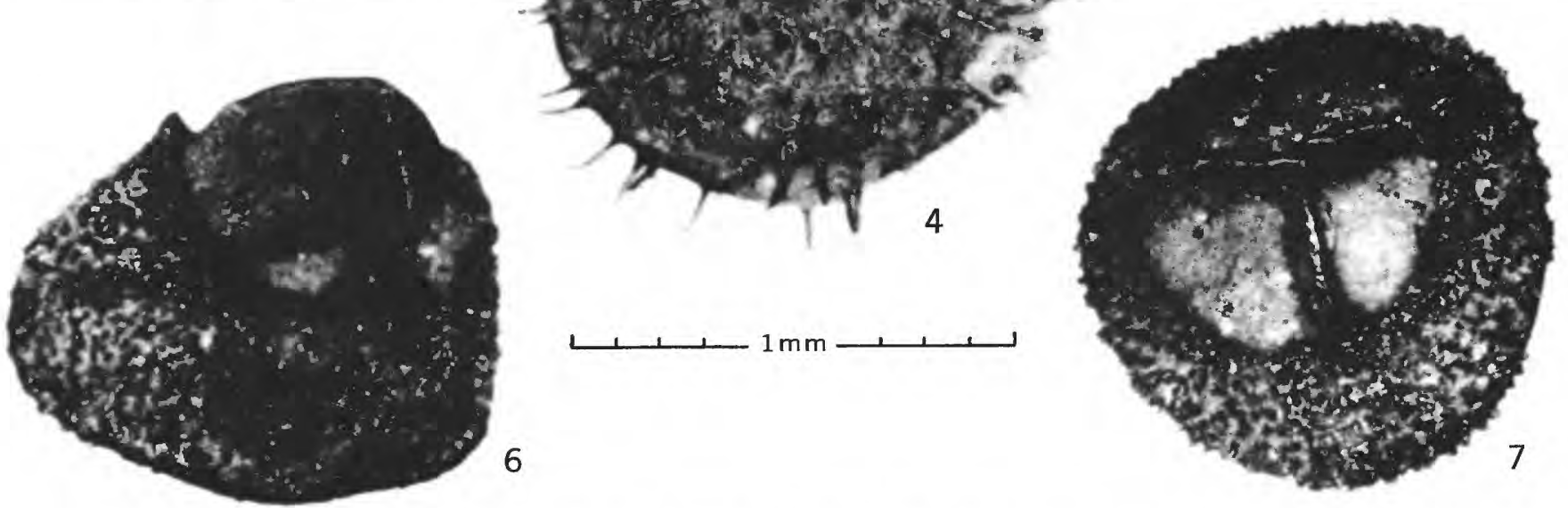

TRILETES? SP. B, T. CATENULATUS N. SP., T. VARIABILIS N. SP.,

T. ARIES N. SP., AND T. TRIQUETRUS N. SP. 


\section{PLATE 8}

Figures 1-7. Triletes globulus n. sp. (p. 36).

1. Lateral compression $500 \mu$ in axial length. The very light area is occasioned by the coincidence of two contact surfaces (thinner coat) on opposite sides of the specimen. Tubercles are extremely small ( $7 \mu-16 \mu$ in diameter). Photographed by strong transmitted light. Scale indicated. Bedford shale, loc. 1, maceration 40A, slide 1, colln. 4-11-1-52.

2. Lateral compression showing distribution and characteristic development of large tubercles and trilete structures, including apex, $570 \mu$ in axial length. Photographed by strong transmitted light. See fig. 1 for scale. Bedford shale, loc. 1 , maceration 38 , slide 1 , colln. 1-5-5-51.

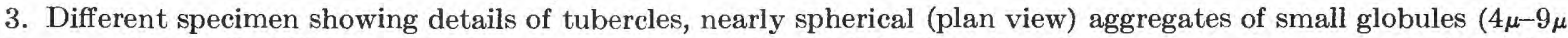
in diameter). Photographed by transmitted light. Scale indicated. Bedford shale, loc. 1, maceration 40A, slide 1, colln. 4-11-1-52.

4. Holotype. Slightly oblique lateral compression $680 \mu$ in axial length. Spore centered over strong beam of light. See fig. 1 for scale. Bedford shale, loc. 2, maceration 161, slide 2, colln. 8-12-6-53.

4a. Same specimen showing detail of tubercles. Basal constrictions may be preservational. Scale indicated.

4b. Same specimen showing detail of part of right contact face. Small tubercles $(10 \mu-20 \mu)$ and wrinkles are present on contact face; larger tubercles are present at arcuate ridge and distally. ar=arcuate ridge; ray=trilete ray. Scale indicated.

5. Proximal view of rare example of megaspore compressed in the proximodistal plane, $700 \mu$ in maximum diameter. Arcuate ridges are distinct. Spore centered over strong beam of light. See fig. 1 for scale. Bedford shale, loc. 1, maceration 40A, slide 7, colln. 4-11-1-52.

6. Lateral compression as photographed by reflected light. See fig. 1 for scale. Bedford shale, loc. 2, maceration 161, colln. 8-12-6-53.

7. Shrunken oblique compression as photographed by reflected light, $450 \mu$ in maximum diameter. See fig. 1 for scale. Bedford shale, loc. 2, maceration 161, colln. 8-12-6-53. 

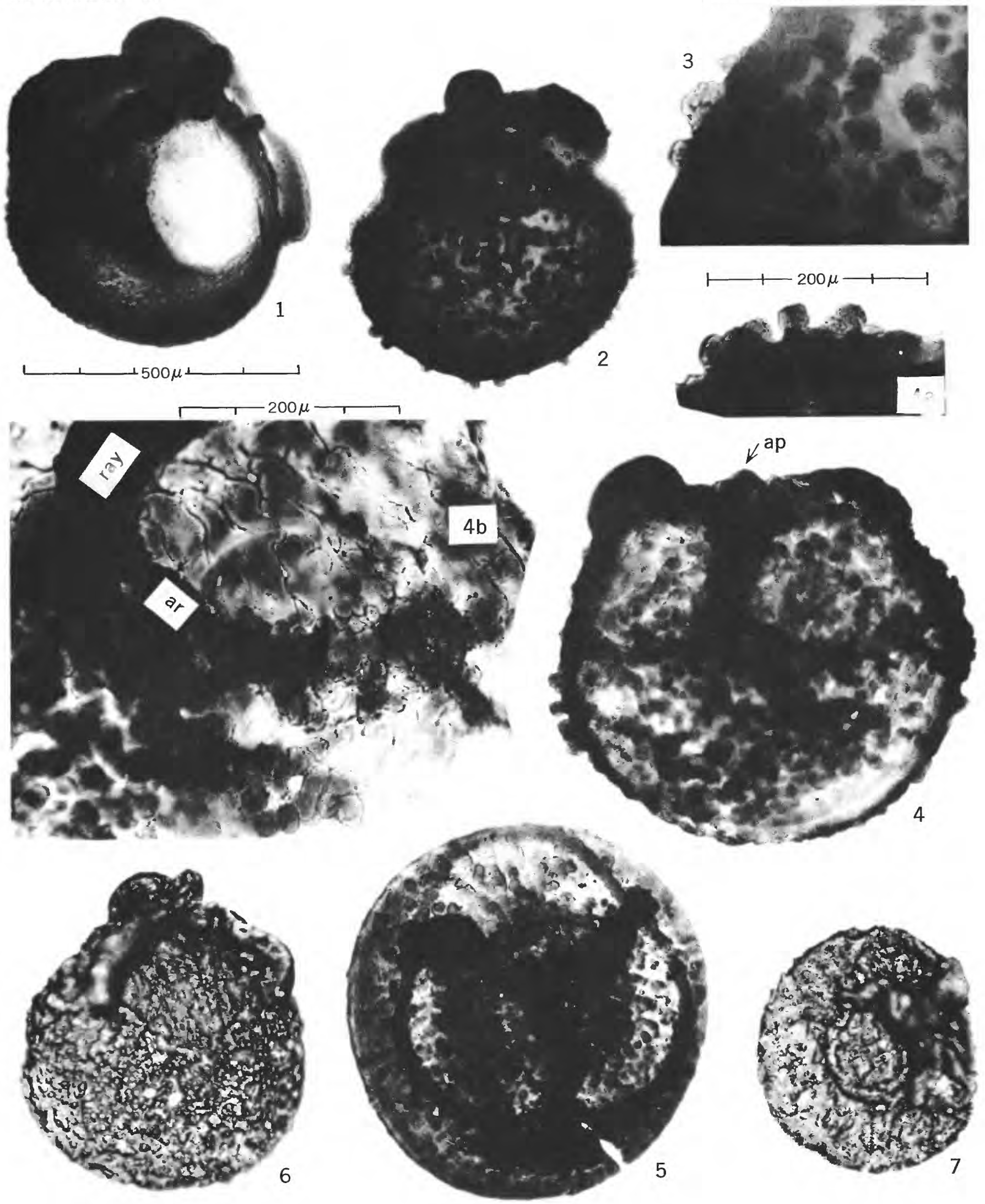

TRILETES GLOBULUS N. SP. 


\section{PLATE 9}

Figures 1, 1a. Triletes globulus n. sp. (p. 36).

Upper part of Bedford shale, loc. 3, maceration 278, slide 1, colln. 2-11-14-53.

1. Three spores of an original tetrad showing distal surfaces covered with hemispherical tubercles. Photographed by reflected light. See fig. 1a for scale.

1a. Same specimens showing proximal surfaces. Two rays on each spore and four contact faces are visible. Fourth spore which covered these features is now missing. Scale indicated.

2-3a. Triletes aries n. sp. (p. 37).

2. Oblique compression showing most of proximal side with high prominent apex (ap). Photographed by reflected light. See fig. 2a for scale. Bedford shale, loc. 2, maceration 161, slide 29, colln. 8-12-6-53.

2a. Same specimen showing distal side. Note large recurved spines interspersed with smaller ones. Scale indicated.

3. Holotype. Proximodistal compression, broken, showing proximal side and apex (ap) extending high above focal plane. Specimen is slightly overmacerated. Photographed by transmitted light. Scale indicated. Bedford shale, loc. 2, maceration 163, slide 1, colln. 9-12-6-53.

3a. Same specimen showing detail of recurved spines, some broken, on distal surface. Arrow indicates position of the same spine on figs. $3 a$ and 3 . Scale indicated. 

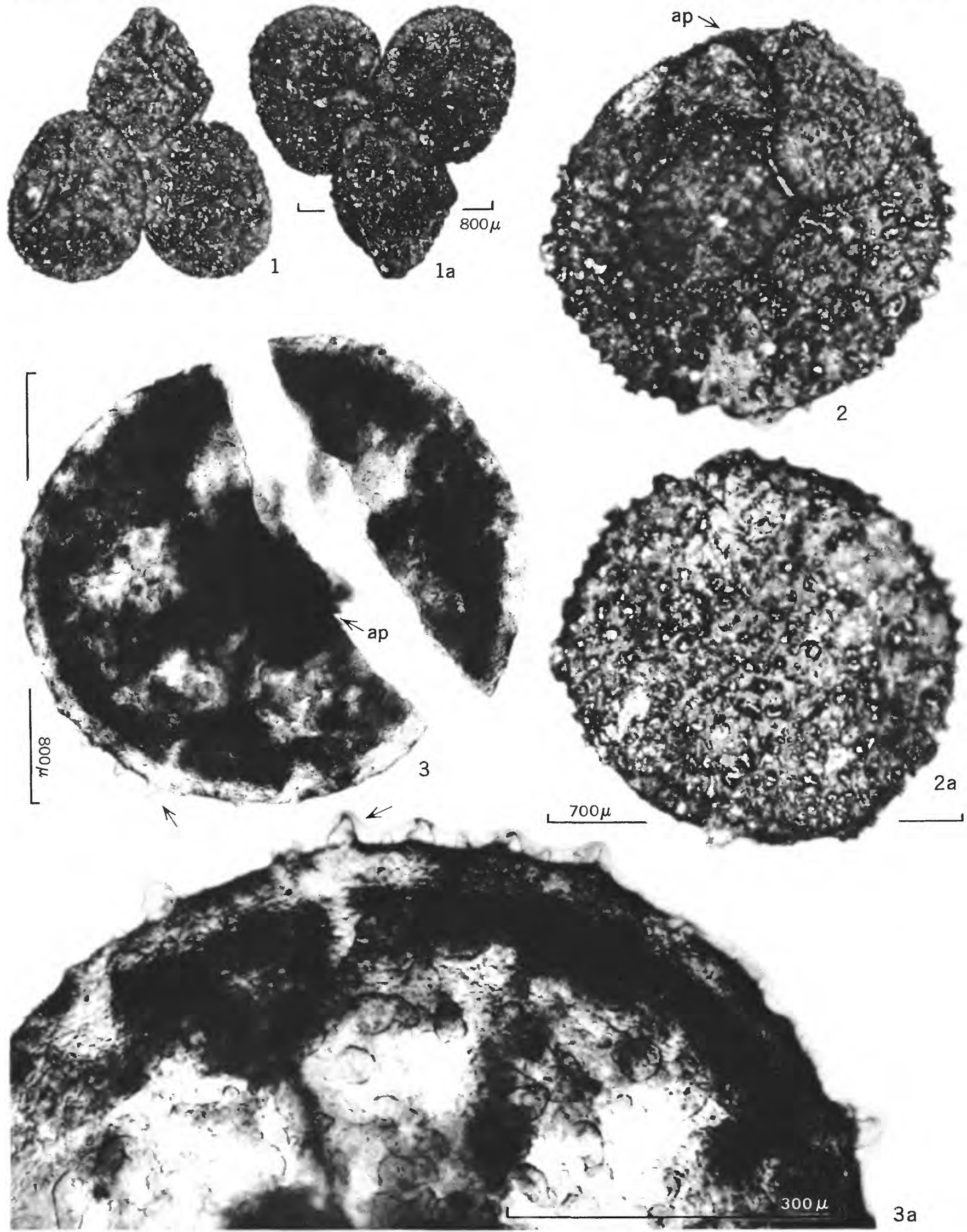

TRILETES GLOBULUS N. SP. AND T. ARIES N. SP. 


\section{PLATE 10}

Figures 1, 1a. Dicrospora sp. (p. 55).

[All photographs, except figure 3, by transmitted light]

Bedford shale, loc. 1, maceration 40B, slide 3, colln. 4-11-1-52.

1. Opaque specimen $265 \mu$ in maximum diameter, bearing long hollow spines. See fig. 4 for scale.

1a. Same specimen. Note abraded bifurcate tip on longest spine. See fig. 5e for scale.

2, 2a. Dicrospora bedfordi n. sp. (p. 53).

See fig. 4 for scale. Bedford shale, loc. 1, maceration 40A, slide 13, colln. 4-11-1-52.

2. Holotype. Proximodistal compression is $330 \mu$ in maximum diameter. Several spines show bifurcate tips.

2a. Same specimen, photographed at a higher focal plane to show high lips.

3-5d. Dicrospora amherstensis n. sp (p. 53).

3. Dry broken specimen as photographed by reflected light. See fig. 4 for scale. Bedford shale, loc. 2, maceration 161, colln. 8-12-6-53.

4. Proximodistal compression showing hollow spine stumps on the distal surface and long bifureate spines. Scale indicated. Bedford shale, loc. 2, maceration 161, slide 20, colln. 8-12-6-53.

5. Holotype. Specimen, only slightly compressed, shows thin lips slightly split apart and arcuate ridge, as photographed over strong beam of light. See fig. 4 for scale. Berea sandstone, loc. 5, maceration 153, slide 1, colln. 1-11-14-53.

5a. Same specimen showing detail of hollow spine shaft. Wall of spine is about $15 \mu-17 \mu$ thick. See fig. $5 \mathrm{~b}$ for scale.

5b. Same specimen. Tips on spine are solid, about $35 \mu-39 \mu$ long. Scale indicated.

5c. Same specimen showing detail of bulbous spine base. Scale indicated.

5d. Same specimen. Spine at top center is same as in fig. 5b. Spine at lower left shows transverse section where bent back upon itself. See fig. $5 \mathrm{c}$ for scale. 
GEOLOGICAL SURVEY
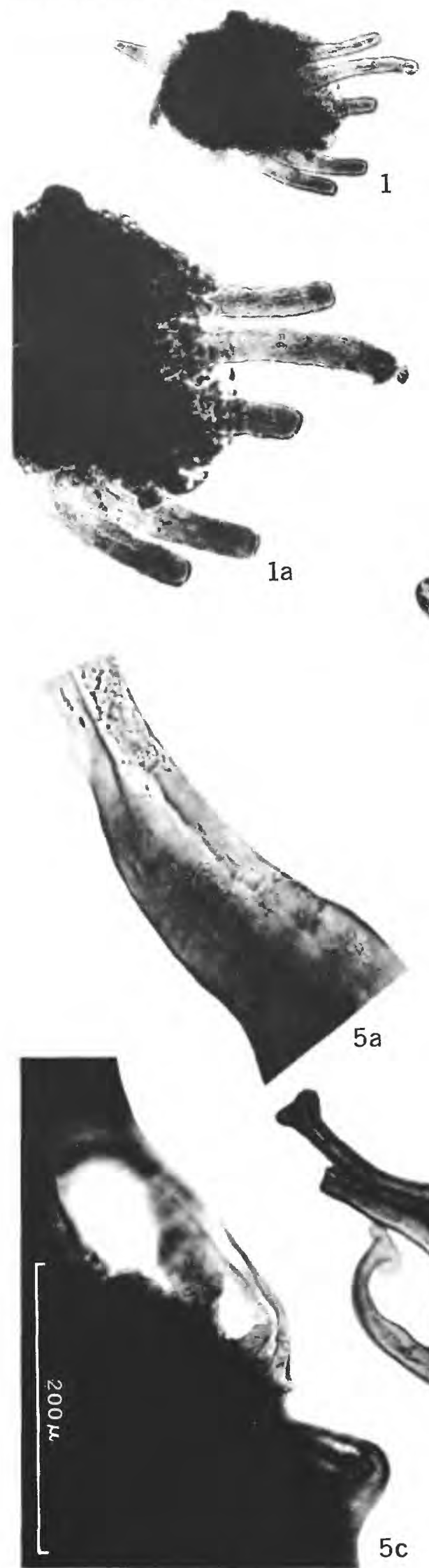
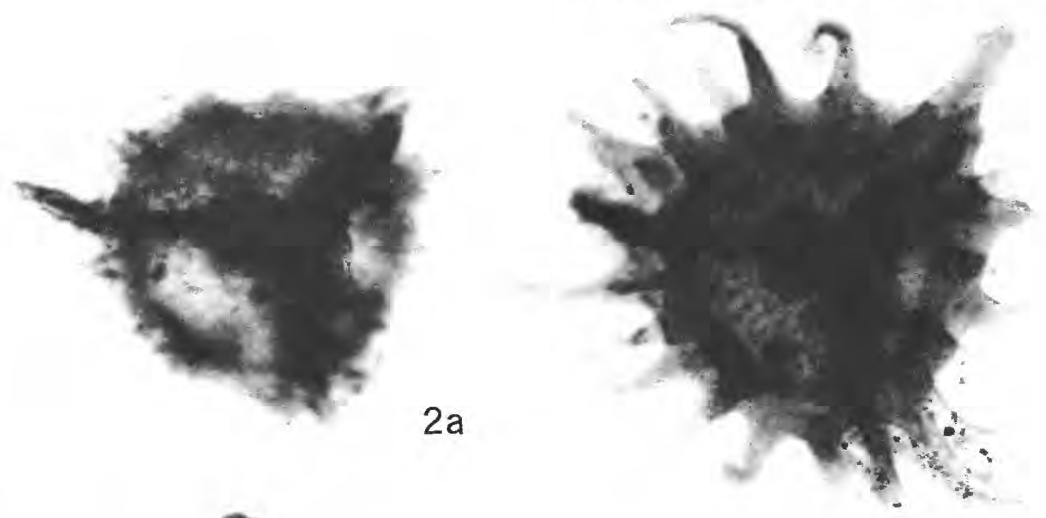

2

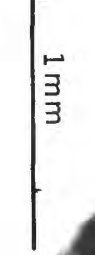

$2 a$
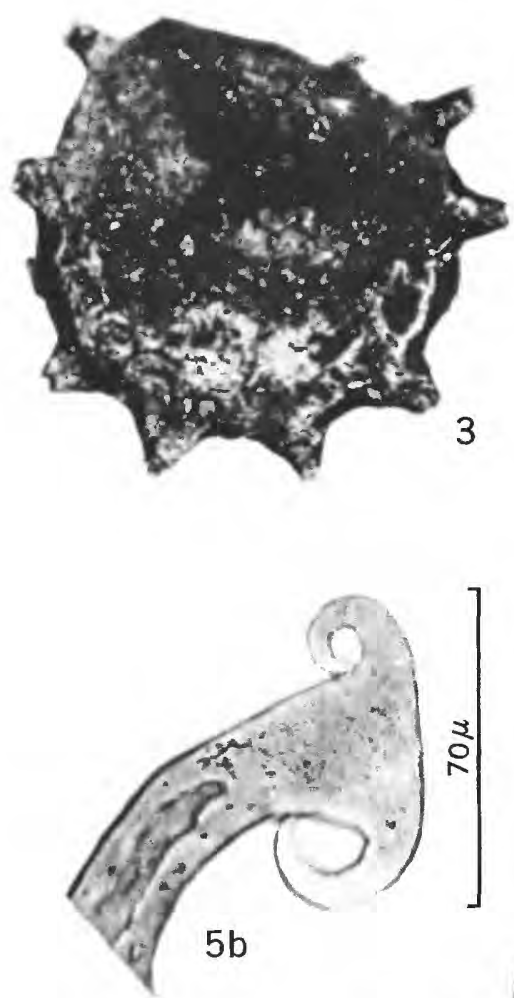

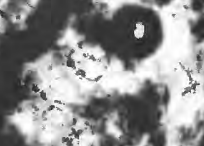

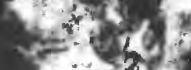
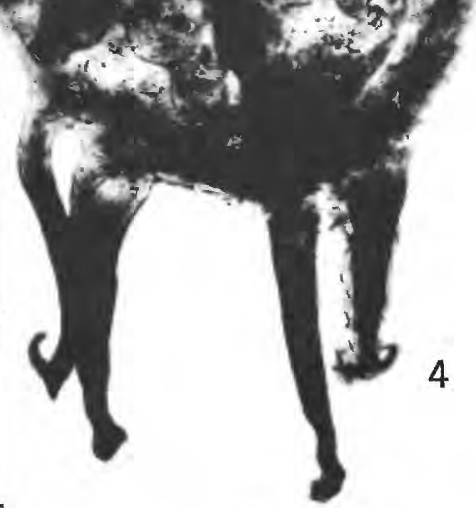


\title{
PLATE 11
}

\author{
[All photographs by transmitted light]
}

Figures 1, 1a. Dicrospora sp. (p. 55).

Bedford shale, loc. 1, maceration 40A, slide 13, colln. 4-11-1-52.

1. Oblique compression about $245 \mu$ in diameter; apex high $(120 \mu)$ and membranous; long hollow spines bifurcate tipped. Distal wall is about $8 \mu$ in thickness. Scale indicated.

1a. Same specimen showing detail of spore coat and spines. See figs. 2 and 5 for scale.

2-3a. Dicrospora sp. A (p. 54).

2. Lateral compression in association with two small spores, $175 \mu$ in axial length. Details of spore body are obscured by included mineral matter. Scale indicated. Chagrin shale, loc. 4, maceration 169, slide 2, colln. 1-1-1-54.

2a. Same specimen showing detail of bifurcate spine and associated resinous-appearing filaments about $1 \mu$ in diameter. Scale indicated.

3. Proximodistal compression $150 \mu$ in diameter. See figs. 2 and 5 for scale. Chagrin shale, loc. 6, maceration 44-1-B, slide 8, colln. 912-792-797.

3a. Same specimen showing detail of proximal surface and tubercles on contact faces. Scale indicated.

4-5a. Dicrospora porcata n. sp. (p. 52).

4. Proximodistal compression, slightly subtriangular, $165 \mu$ in diameter. Broad ridges on contact faces radiate from apex. See figs. 2 and 5 for scale. Chagrin shale, loc. 6, maceration 44-1-B, slide 8, colln. 912-792-797.

5. Two spores of a tetrad, each spore about $130 \mu$ in diameter. Scale indicated. Chagrin shale, loc. 6, maceration 44-1-B, slide 8, colln. 912-792-797.

5a. Same specimen showing ridges and grooves on contact face and two bifurcate tipped spines. Arcuate ridge $(14 \mu-16 \mu$ wide) is distinct. See fig. $3 a$ for scale. 

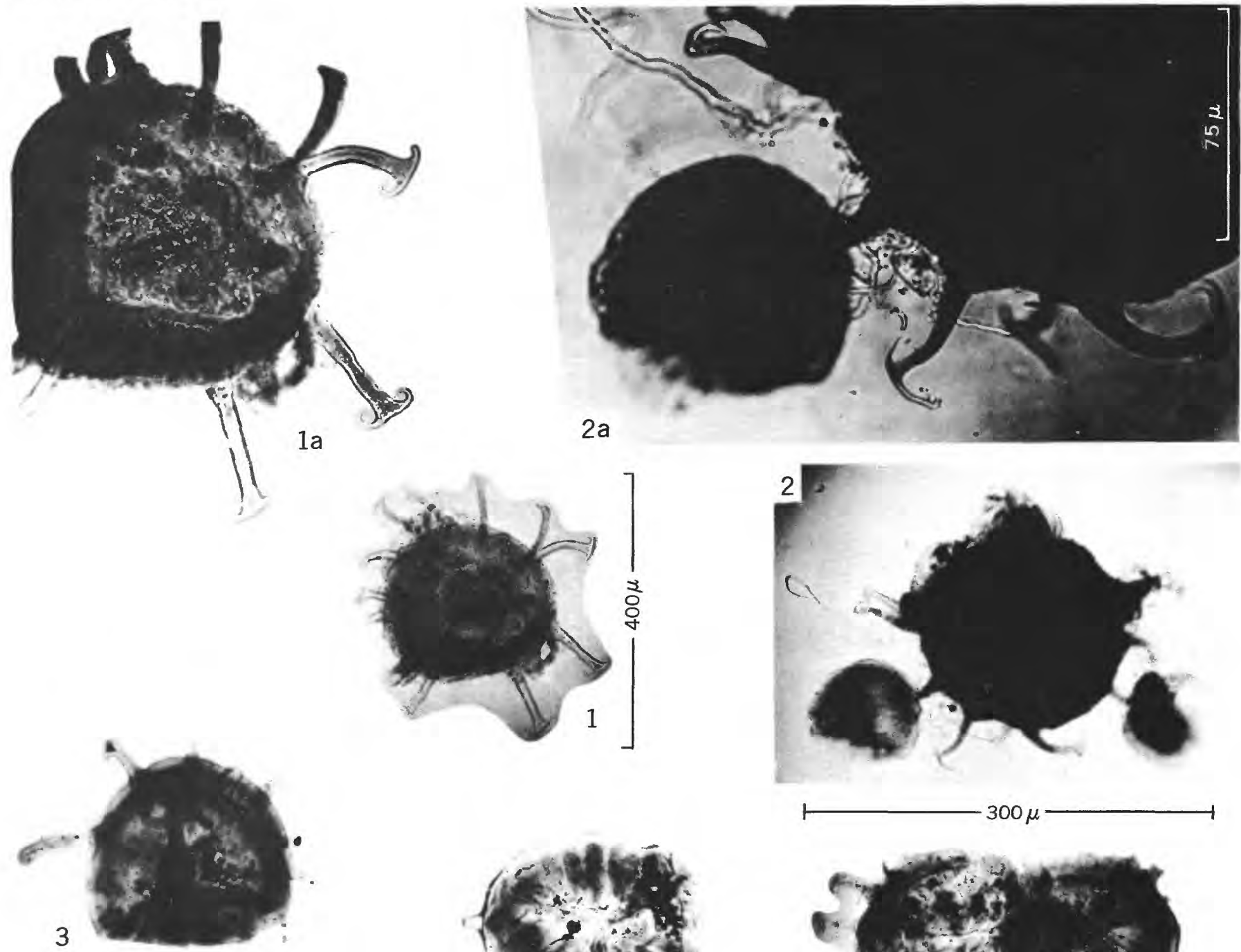

*
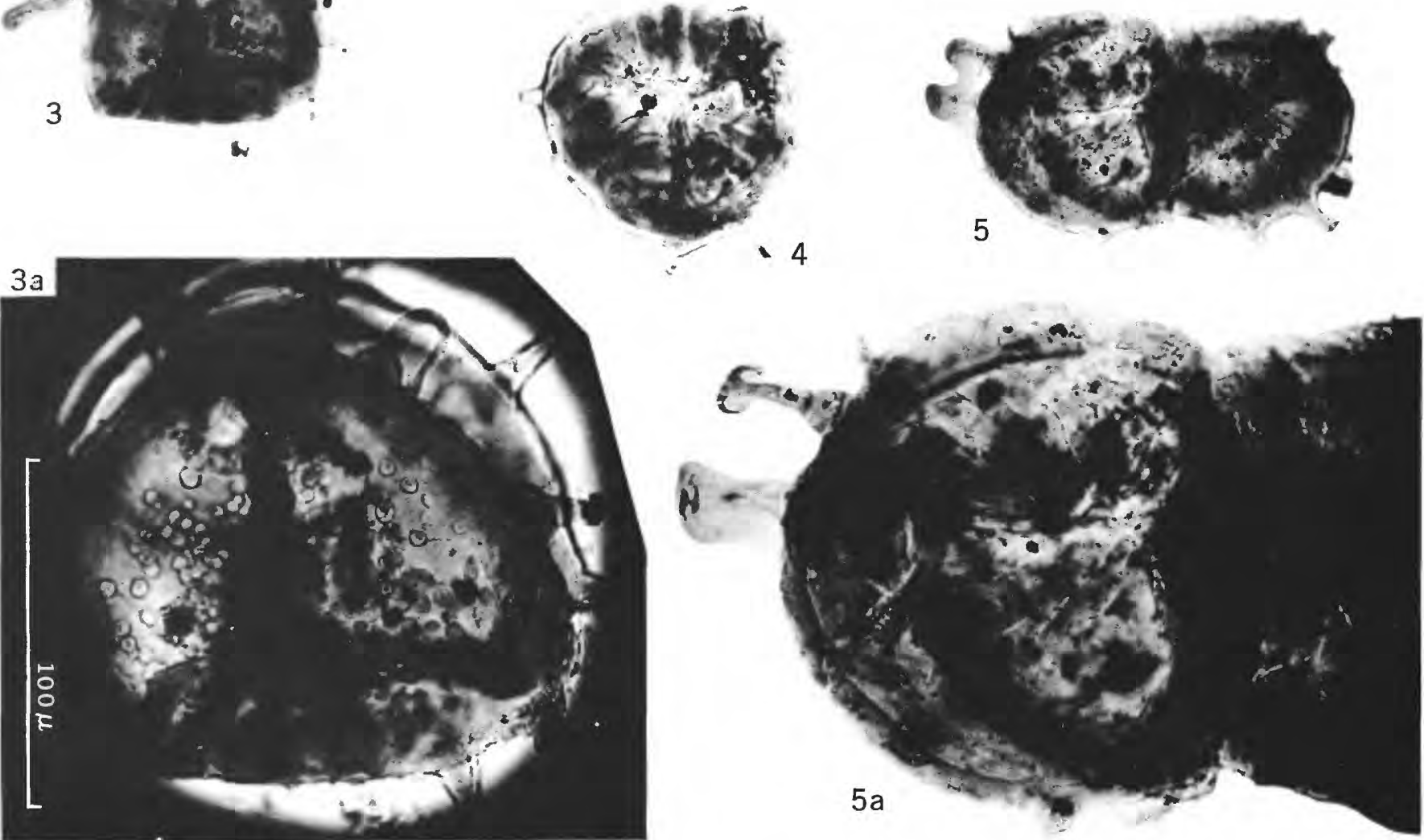

DICROSPORA SP., D. SP. A, AND D. PORCATA N. SP. 


\section{PLATE 12}

Figure 1. Dicrospora sp. (p. 55).

[All photographs by transmitted light]

Lateral compression about $280 \mu$ in axial length. Spines are short $(30 \mu-45 \mu)$, numerous, and with bifurcate tips. Spore coat is $12 \mu$ thick. See fig. 5 for scale. Bedford shale, loc. 2, maceration 163, slide 9, colln. 9-12-6-53.

2. Dicrospora sp. B (p. 55).

Oblique compression, distal view, showing short bifurcate spines. See fig. 5 for scale. Bedford shale, loc. 2 , maceration 163, slide 9, colln. 9-12-6-53.

3, 3a. Dicrospora sp. C (p. 55).

Bedford shale, loc. 1, maceration 40C, slide 2, colln. 4-11-1-52.

3. Lateral compression, $280 \mu$ in axial length, showing high apex. See fig. 5 for scale.

3a. Same specimen showing detail of spines. See fig. 8 a for scale.

4, 4a. Dicrospora sp. (p. 55).

Chagrin shale, loc. 4, maceration 169, slide 2, colln. 1-1-1-54.

4. Spore body filled with mineral matter about $122 \mu$ in maximum diameter. See fig. 5 for scale.

4a. Same specimen showing detail of well-preserved bifurcate spines, $60 \mu-70 \mu$ long. See fig. $8 \mathrm{a}$ for scale.

5. Dicrospora porcata n.sp. (p. 52).

Tetrad of immature(?) spores somewhat disorganized by compression, about $130 \mu$ in average diameter. Spines are thick, short, and bifurcate. Scale indicated. Bedford shale, loc. 2, maceration 163, slide 7, colln. 9-12-6-53.

6. Dicrospora sp. (p. 55).

Proximodistal compression with proximal area missing, showing sinuous tapering bifurcate spines about $110 \mu-150 \mu$ long. Specimen is unique in the medusalike appearance of the spines. See fig. 5 for scale. Bedford shale, loc. 1 , maceration 160, slide 1 colln. 15-12-6-53.

7, 7a. Dicrospora multifurcata var. impensa n. var. (p. 54).

Chagrin shale, loc. 4, maceration 169, slide 2, colln. 1-1-1-54.

7. Holotype, about $320 \mu$ in axial length. Spines are long $(130 \mu-200 \mu)$, collapsed, bifurcate and multipartite. Note thin resinous-appearing filaments entangled with spines. Scale indicated.

7a. Same specimen showing detail of three-pronged spine. Scale indicated.

8-8b. Dicrospora multifurcata n. sp. (p. 53).

Chagrin shale, loc. 4, maceration 169, slide 2, colln. 1-1-1-54.

8. Two nearly opaque spores, one at upper right probably abortive. See fig. 5 for scale.

8a. Same specimen showing three-pronged multipartite spine. Scale indicated.

8 b. Same specimen showing six-pronged multipartite spine. See fig. $8 \mathrm{a}$ for scale. 

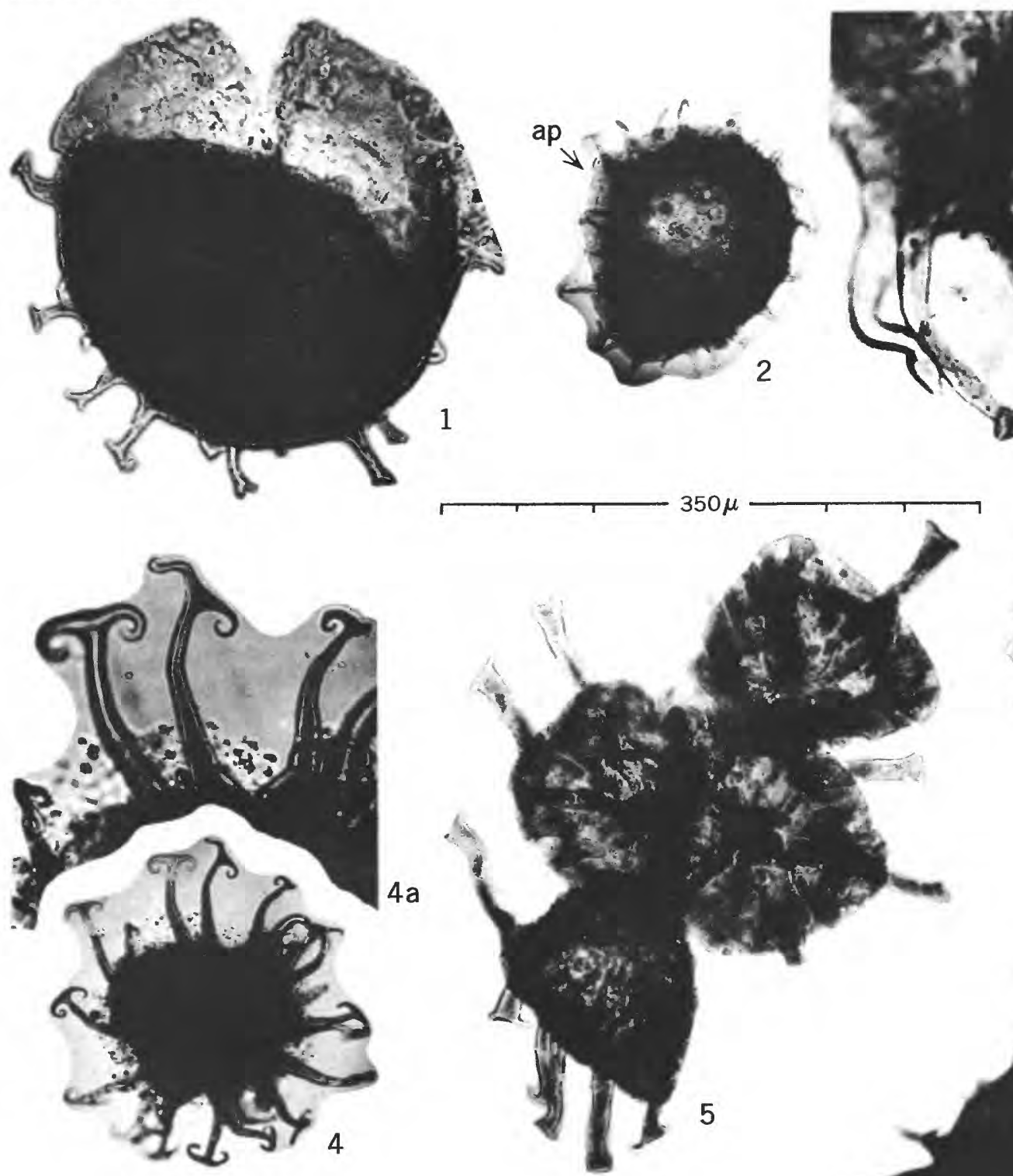

$350 \mu$
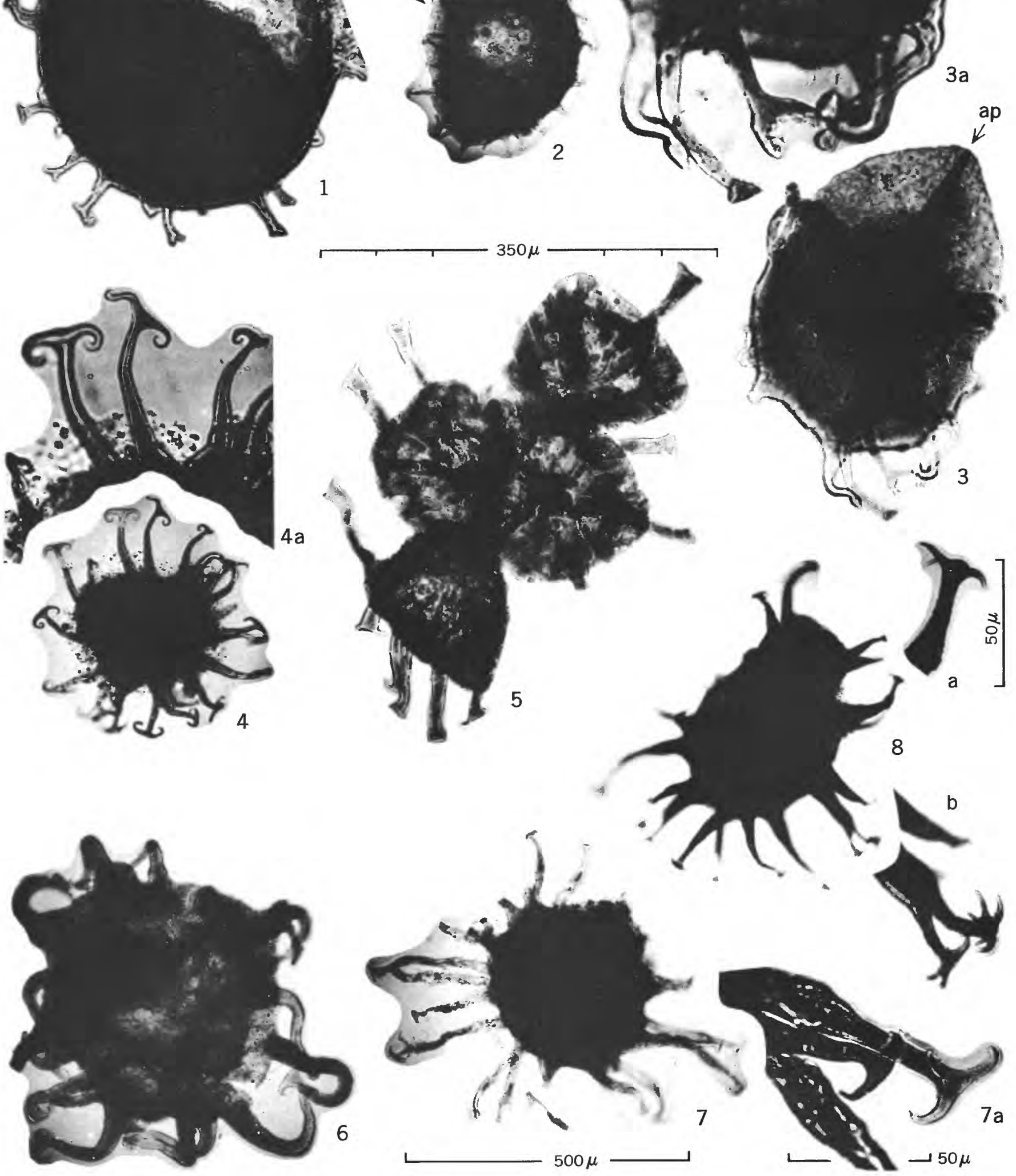

DICROSPORA N. GEN. 
PLATE 13

[All photographs by transmitted light]

Figures 1-6. Dicrospora multifurcata n. sp. (p. 53).

1. Lateral compression, $100 \mu$ in axial length, with apex (ap) broken. Tiny cubes of pyrite are present in the cavities of the hollow multipartite spines. See fig. 6 for scale. Photographed with a blue-green filter. Chagrin shale, loc. 6, maceration 44-1-B, slide 2, colln. 912-792-797.

2. Lateral compression, including apex, $220 \mu$ in axial length, showing stout multipartite spines. Scale indicated. Chagrin shale, loc. 6, maceration 44-1-B, slide 10, colln. 912-792-797.

3. Lateral compression, including apex, $120 \mu$ in axial length, showing spatulate shape of lips. See fig. 2 for scale. Photographed with a blue-green filter. Chagrin shale, loc. 6, maceration 44-1-B, slide 1, colln. 912-792-797.

4. Holotype. Lateral compression, including apex, $180 \mu$ in axial length. Spines are multipartite, about $85 \mu$ in length. See fig. 2 for scale. Chagrin shale, loc. 6, maceration 44-1-B, slide 3, colln. 912-792-797.

4a. Same specimen showing detail of body. Lips are about $60 \mu$ high, fused at edges and partly filled with pyrite, as photographed with an indigo filter. See fig. 2 for scale.

5. Oblique compression. Body and spines are filled with pyrite. See fig. 2 for scale. Chagrin shale, loc. 4, maceration 169 , slide 5 , colln. 1-1-1-54.

6. Oblique compression. Cubes of pyrite fill the hollow spines and spore body. Spine at extreme right has seven prongs. Scale indicated. Chagrin shale, loc. 4, maceration 169, slide 5, colln. 1-1-1-54.

7-9. Details of spines from spores of Dicrospora multifurcata n. sp. Scale indicated beside fig. 8 . Chagrin shale, loc. 4 . maceration 169, slide 3, colln. 1-1-1-54.

7. Six prongs of spinal termination clearly visible.

8. Six-pronged spine as photographed with a blue-green filter.

9. Six-pronged hollow spine, about $90 \mu$ long. 


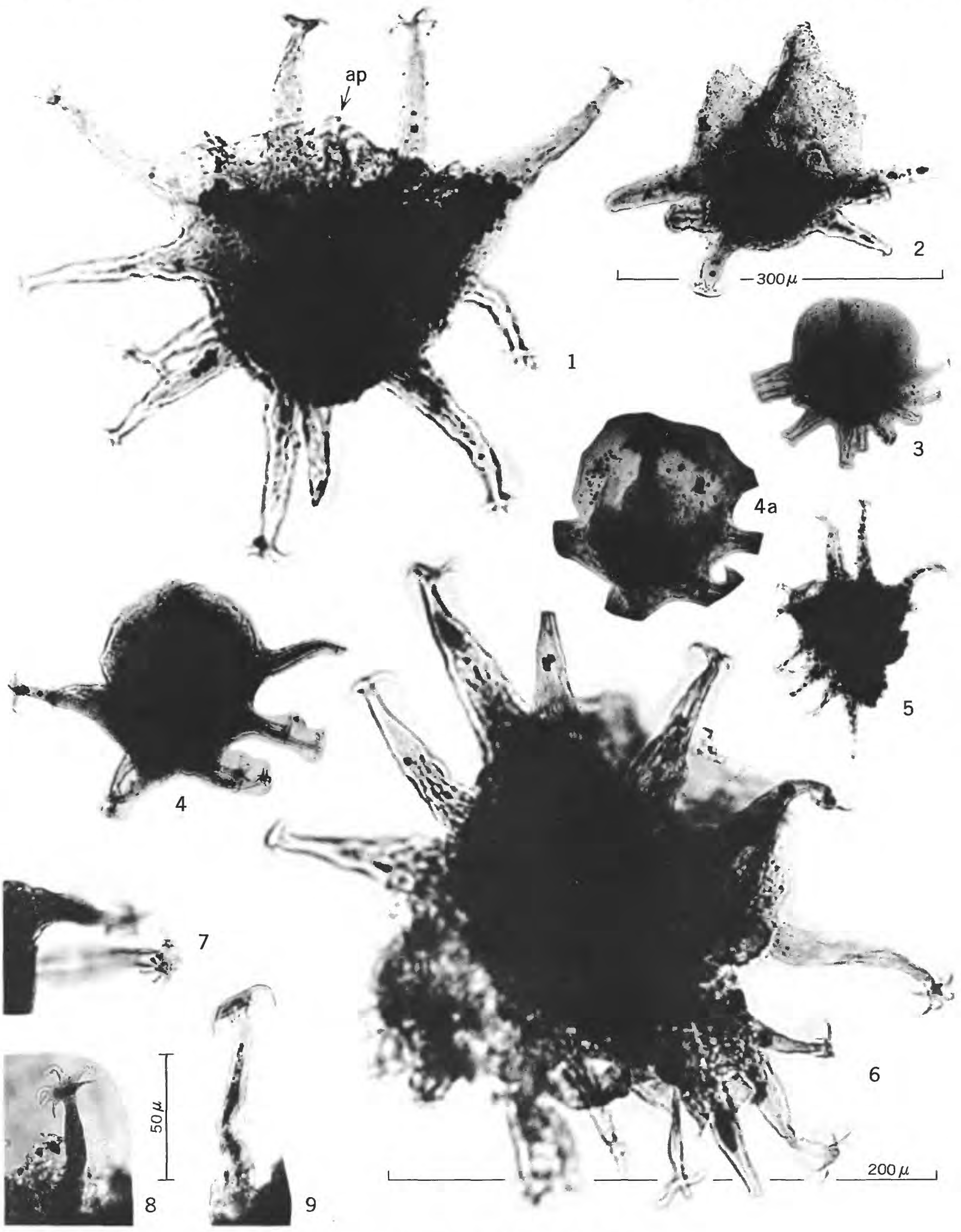

DICROSPORA MULTIFURCATA N. SP. 


\section{PLATE 14}

[All photographs by transmitted light]

Figures 1-3a. Reticulatisporites? fimbriatus n. sp. (p. 58).

1. Holotype $84 \mu$ in diameter including muri. Silhouette shows deeply fringed muri as photographed with a bluegreen filter. See fig. 5 for scale. Bedford shale, loc. 1, maceration 40B, slide 16, colln. 4-11-1-52.

1a. Same specimen showing details of distal surface. At least four lacunae are distinct. See fig. 5 for scale.

1b. Same specimen showing details of proximal surface. Part of trilete suture and fringed muri bordering suture are visible. See pl. 22 , fig. 21 , for drawing of specimen. See fig. 5 for scale.

2. Another specimen, lateral compression, $87 \mu \times 96 \mu$ including muri. Silhouette shows fringed muri as photographed with a blue-green filter. Scale indicated. Bedford shale, loc. 2, maceration 159, slide 2, colln. 7-12-6-53-b.

2a. Same specimen as fig. 2. Apex or proximal pole is located in upper central part of figure. Note mural rim, around the rather oblate spore, slightly proximal to the geometrical equator. Safranin stained. See fig. 2 for scale.

3. Large specimen $98 \mu$ in diameter including muri. Silhouette of muri as photographed with a blue-green filter. Scale indicated. Bedford shale, loc. 1, maceration 40B, slide 22, colln. 4-11-1-52.

3a. Same specimen as fig. 3. Spore body (excluding muri) is about $76 \mu$ in diameter. Muri are about $14 \mu$ high, not as deeply fringed as those on specimen shown in fig. 2 a. Trilete rays are distinct, $28 \mu$ long. Scale indicated.

4-5. Reticulatisporites? fimbriatus var. spathulatus n. var. (p. 59).

4. Holotype about $63 \mu$ in diameter excluding projections. Muri are deeply and coarsely fringed into rather spatulate processes, some of which are partite terminally. Photographed with a blue-green filter. See fig. 5 for scale. Bedford shale, loc. 1, maceration 40B, slide 15, colln. 4-11-1-52.

4a. Same specimen showing vague reticulate pattern. See pl. 22 , fig. 22 , for drawing of distal surface. See fig. 5 for scale.

5. Large specimen $77 \mu$ in diameter excluding processes which are as much as $16 \mu$ long. Muri are even more deeply dissected and projections stouter than on specimen shown in fig. 4 and $4 \mathrm{a}$. Trilete rays are $21 \mu$ long, bordered by muri at their terminations. Scale indicated. Bedford shale, loc. 1, maceration 160 , slide 10, colln. 1512-6-53.

6. Reticulatisporites? sp. (p. 60).

Maximum diameter, including mural rim, $130 \mu$. Three distinct muri radiate from the distal pole. Two of these muri branch before juncture with equatorial rim. Preservation is poor; most of proximal surface is missing.

See fig. 7 for scale. Bedford shale, loc. 1, maceration $40 \mathrm{C}$, slide 5, colln. 4-11-1-52.

7. Reticulatisporites? sp. (p. 60).

Maximum diameter, includng mural rim, $128 \mu$. Rays are about $35 \mu$ long, open; apical segments turned outward. Spore coat is about $3 \mu$ thick over contact areas; lips are about $4 \mu$ high at apex. Several muri branch from the equatorial rim toward the distal pole but are poorly developed. Scale indicated. Bedford shale, loc. 1, maceration 160 , slide 7 , colln. 15-12-6-53.

8-10a. Reticulatisporites crassus n. sp. (p. 58).

8. Holotype about $100 \mu$ in diameter including mural rim. Spore (distal surface up) has 7 lacunae, the most distal of which is almost bisected by 1 murus. Trilete suture is fairly distinct. See figs. 10 and 10 a for scale. Lower part of Cuyahoga formation, loc. 8, maceration 148, slide 9.

9. Proximodistal compression, proximal surface up, $117 \mu$ in maximum diameter. Suture is distinct and open. See pl. 22, fig. 23, for drawing of proximal surface. See figs. 10 and 10a for scale. Lower part of Cuyahoga formation, loc. 8, maceration 148, slide 13 .

10. Proximodistal compression, distal surface up, $120 \mu$ in maximum diameter. Termini of trilete suture are distinct; rays are about $36 \mu$ in length. Scale indicated. Lower part of Cuyahoga formation, loc. 8, maceration 148, slide 13.

10a. Same specimen photographed at a higher focal plane to show muri traversing distal surface. Seven lacunae are distal to the equatorial rim of muri. The most distal lacuna is almost bisected by one murus, but this feature is obscured in the photograph by cubes of pyrite inside the spore coat. Scale indicated. 

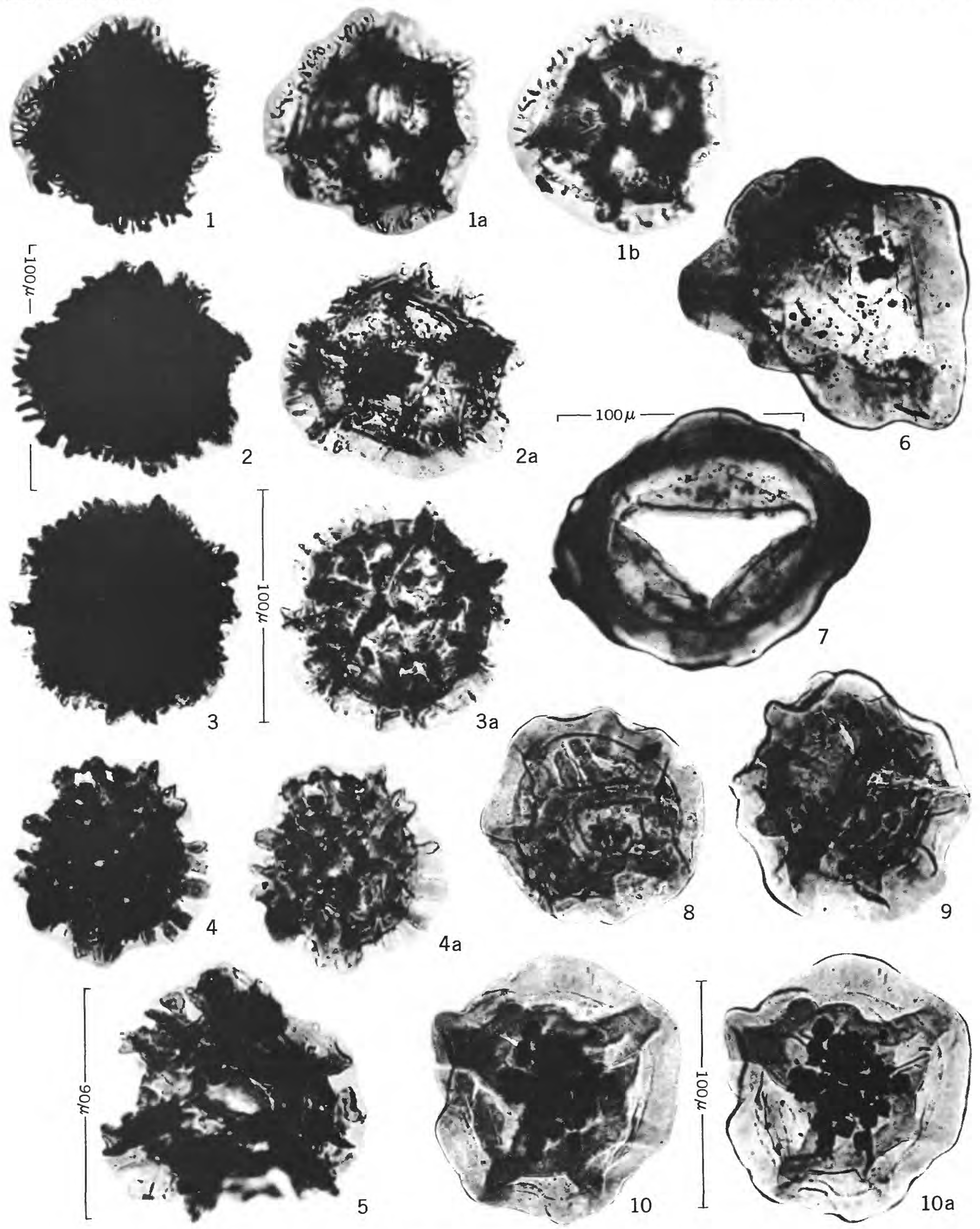

\section{$4 a$}
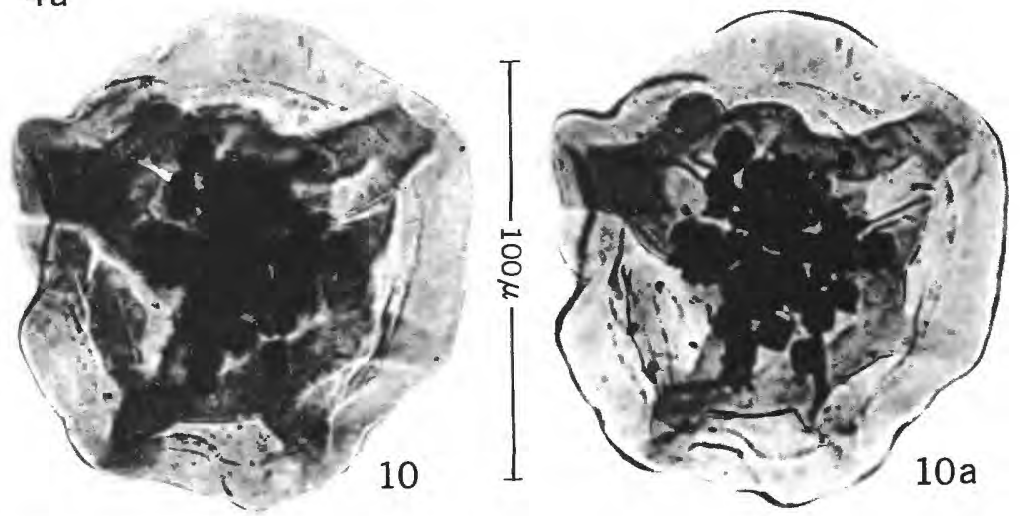

RETICULATISPORITES 


\section{PLATE 15}

Figure 1. Laevigatosporites sp. (p. 66).

[All photographs by transmitted light]

Specimen $60 \times 74 \mu$ with monolete suture $37 \mu$ long. Photographed with a blue-green filter. Scale indicated. Berea sandstone, loc. 5, maceration 153, slide 5, colln. 1-11-14-53.

2, 3. Canthospora cracens n. sp. (p. 69).

2. Typically folded proximodistal compression, about $136 \mu$ in diameter. Cingulum is $11 \mu-12 \mu$ wide in optical section, thinning rapidly toward proximal and distal poles. Scale indicated. Bedford shale, loc. 2, maceration 161, slide 28 , colln. 8-12-6-53.

3. Holotype about $119 \mu$ in diameter. Cingulum, where torn at left, shows in oblique cross section. Distal spore coat thickening shows in vague outline below part of suture. See fig. 6 for scale. Bedford shale, loc. 1, maceration 40B, slide 13, colln. 4-11-1-52.

4. Canthospora patula n. sp. (p. 68).

Spore, $149 \mu$ in diameter, showing thin broken and folded proximal and distal coat. Cingulum is rather regular in outline. Scale indicated. Bedford shale, loc. 1, maceration 40B, slide 19, colln. 4-11-1-52.

5. Canthospora sp. (p. 70).

Spore $100 \mu$ in diameter. Trilete suture is distinct. See fig. 6 for scale. Bedford shale, loc. 2, maceration 159, slide 9, colln. 7-12-6-53-b.

6. Canthospora patula n. sp. (p. 68).

Holotype $132 \mu$ in diameter. Spore shows typical development of outer irregular spore coat layer of cingulum. Lips apparent near proximal pole. Scale indicated. Bedford shale, loc. 1, maceration 40C, slide 27, colln. 4-11-1-52.

7-7b. Canthospora sp. (p. 70).

Scale indicated under fig. 7b. Bedford shale, loc. 1, maceration 40C, slide 7, colln. 4-11-1-52.

7. Proximodistal compression $135 \mu$ in diameter. Distal surface up. Focus at a high plane shows folded thin distal coat with distal thickening and tubercles adjacent to cingulum.

7a. Same specimen with focus at an intermediate plane corresponding to the margin of the cingulum.

$7 \mathrm{~b}$. Same specimen with focus at a lower plane corresponding to the level of the proximal side of spore, showing trilete suture; apex obscured by the shadow of the distal boss.

8-10. Laevigatosporites spp. (p. 66).

8. Specimen $92 \mu$ long, probably originally nearly spherical, with monolete suture $45 \mu$ long. Spore coat, $3 \mu$ thick, is ornamented with closely spaced sharply pointed protuberances. Photographed with a blue-green filter. See fig. $7 \mathrm{~b}$ for scale. Bedford shale, loc. 1, maceration 40C, slide 18, colln. 4-11-1-52.

8a. Same specimen showing ornamentation and optical section of spore coat. See fig. $7 \mathrm{~b}$ for scale.

9. Folded specimen about $70 \mu$ long with monolete suture $40 \mu$ long hidden under mineral matter. Spore coat is smooth and thick $(3.4 \mu)$. Safranin stained. See fig. 1 for scale. Berea sandstone, loc. 5, maceration 153, slide 24, colln. 1-11-14-53.

10. Specimen, folded along monolete suture, $58 \mu$ long. Spore coat is smooth, about $3.5 \mu$ thick. High, medium, and low focal planes superimposed on negative. Photographed with a blue-green filter. See fig. 6 for scale. Berea sandstone, loc. 5, maceration 153, slide 5, colln. 1-11-14-53. 

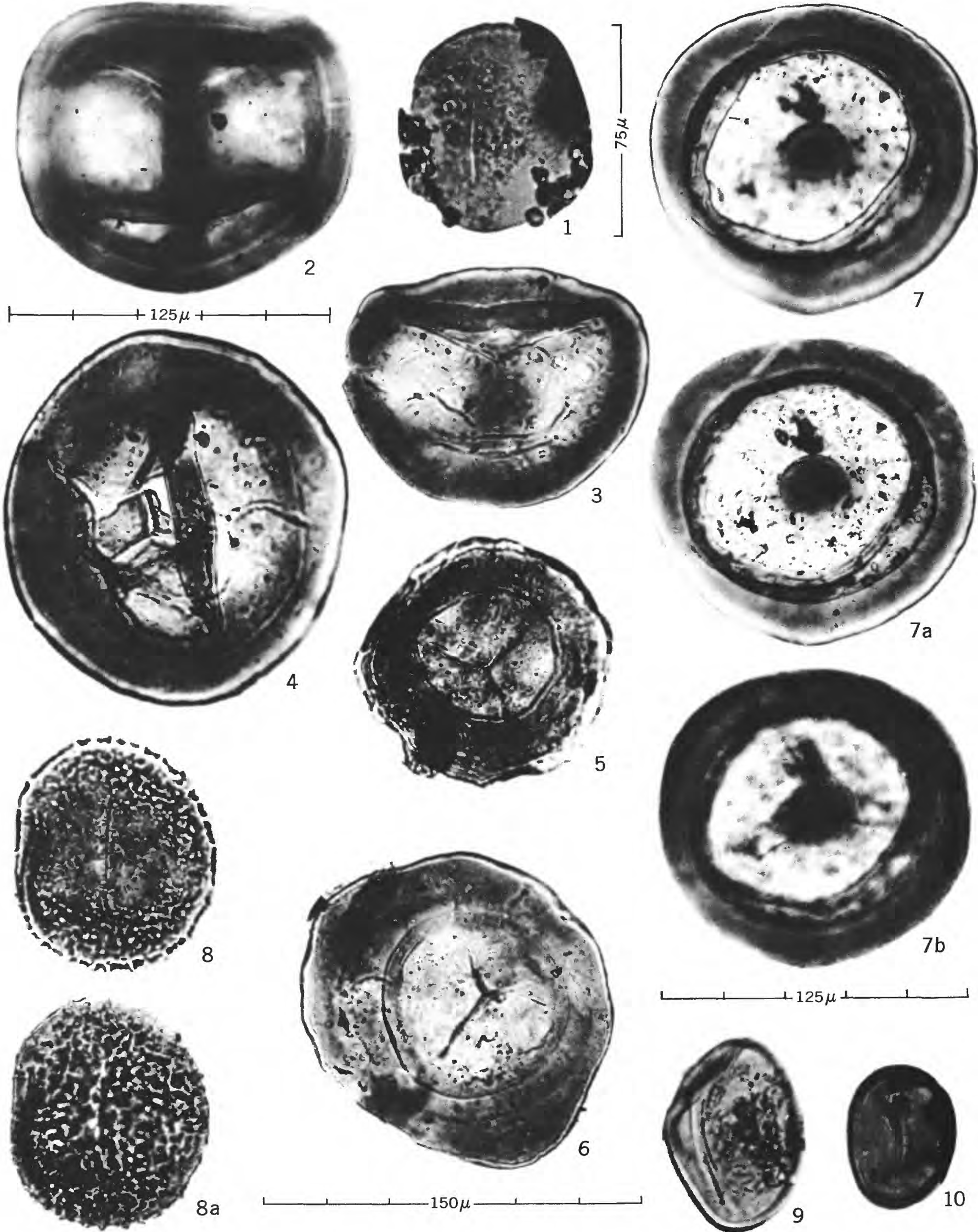

$\perp 125 \mu$
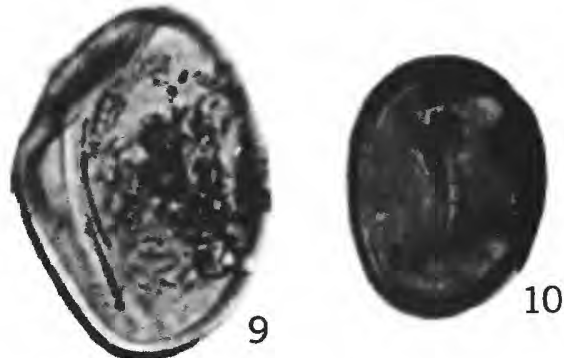

LAEVIGATOSPORITES AND CANTHOSPORA N. GEN. 


\title{
PLATE 16
}

\author{
[All photographs by transmitted light]
}

Figures 1-5. Endosporites lacunosus n. sp. (p. 44).

1. Specimen $86 \mu$ in diameter, showing distinct trilete rays extending to bladder margin. Pits on distal surface of bladder, as much as $4 \mu$ in diameter. Photographed with a blue-green filter. See figs. 11 and 15 for scale. Bedford shale, loc. 1, maceration 40B, slide 22, colln. 4-11-1-52.

2. Specimen $74 \mu$ in diameter, bladder rim folded up toward proximal pole; distal surface of bladder torn. Pits in bladder membrane are as much as $3 \mu$ in diameter. Safranin stained. See figs. 11 and 15 for scale. Berea sandstone, loc. 5, maceration 153, slide 21, colln. 1-11-14-53.

3. Small specimen $61 \mu$ in diameter, showing three dark apical papillae. Specimen is oriented distal side up, with distal bladder coat folded. Safranin stained, photographed with a blue-green filter. See figs. 11 and 15 for scale. Berea sandstone, loc. 5, maceration 153, slide 4, colln. 1-11-14-53.

4. Specimen $90 \mu$ in diameter, asymmetrically subtriangular in outline, showing distal bladder pits as li rht oval areas and indistinct apical papillae. Photographed with a blue-green filter. See fig. 12 for scale. Bedford shale, loc. 2, maceration 163, slide 12, colln. 9-12-6-53.

5. Holotype $76 \mu$ in total diameter; spore body $53 \mu$ in diameter. Trilete rays are distinct and $4 \mu$ high at proximal pole. Part of pitted distal bladder is torn away at lower margin showing unornamented proximal bladder coat. Bladder rim and tiny spinules are shown along upper margin. Fold is developed in distal bladder membrane. Safranin stained. See fig. 12 for scale. Berea sandstone, loc. 5, maceration 153, slide 23, colln. 1-11-14-53.

6-9. Endosporites? pseudoradiatus n. sp. (p. 45).

6. Specimen $243 \mu$ in diameter, badly abraded, showing bladder split open at lower margin. Scale indicated. Bedford shale, loc. 1, maceration 160, slide 1, colln. 15-12-6-53.

7. Holotype $283 \mu$ in diameter, showing long sinuous trilete rays and typical interradial bladder folds. See figs. 6 and 9 for scale. Bedford shale, loc. 1, maceration 40C, slide 10, colln. 4-11-1-52.

8. Specimen $316 \mu$ in diameter, with a more rounded outline. Rays divide at termini and recurve parallel to margin, simulating arcuate ridges. Note optical section showing thickness at margin of bladder. Extreme mottled appearance is a preservational feature. See figs. 6 and 9 for scale. Bedord shale, loc. 2, maceration 161, slide 6, colln. 8-12-6-53.

9. Specimen $305 \mu$ in diameter, with bladder and spore body folded concentrically, rather than radially. Note that the sinuous trilete rays are slightly offset from the corners of the spore body to suggest that the spore body and bladder are connected only near the apex. Scale indicated. Bedford shale, loc. 1, maceration $40 \mathrm{C}$, slide 10 , colln. 4-11-1-52.

10. Endosporites chagrinensis n. sp. (p. 43).

Holotype $123 \mu$ in diameter, proximodistally compressed. Bladder shows many small folds; suture is slightly parted. See fig. 12 for scale. Cleveland member of the Ohio shale, loc. 6, maceration 442, slide 5 .

11. Endosporites sp. A (p. 45).

Specimen $80 \mu$ in diameter. Body wall is $2.7 \mu$ thick; bladder is very thin. Trilete rays are restricted to spore body. Mineral matter is included within the spore causing dark speckling. Photographed with a blue-green filter. Scale indicated. Uppermost part of Chagrin shale, loc 1, maceration 154, slide 3, colln. 10-12-6-53.

12. Grandispora sp. (p. 66).

Specimen $88 \mu$ in diameter, distal side up. Scale indicated. Chagrin shale, loc. 6, maceration 421 , slide 4 .

13. Endosporites $\mathrm{sp}$. B (p. 45).

Specimen about $178 \mu$ in diameter, proximal side up. Trilete rays are as much as $4 \mu$ in height. Scale indicated. Berea sandstone, loc. 9, maceration 317 , slide 2, colln. 1-5-3-53.

14. Endosporites? sp. (p. 48).

Specimen $130 \mu$ in diameter. Lips are about $3 \mu$ high at proximal pole. See figs. 11 and 15 for scale. Uppermost part of Chagrin shale, loc. 1, maceration 154, slide 2, colln. 10-12-6-53.

15, 15a. Radforthia radiata $\mathrm{n}$. sp. (p. 72).

Basal part of Sunbury shale, loc. 9, maceration 151-3, slide 8, colln. 2-5-3-53.

15. Specimen $65 \mu$ in diameter, proximodistal compression, distal side up. Focus is on distal surface, showing granulose distal surface and spore coat thickness. Foreign particles cover lower right-hand part of spore. Safranin stained. Scale indicated.

15a. Same specimen photographed at lower focal plane than fig. 15 showing suture and proximal radial ridges. See figs. 11 and 15 for scale. 

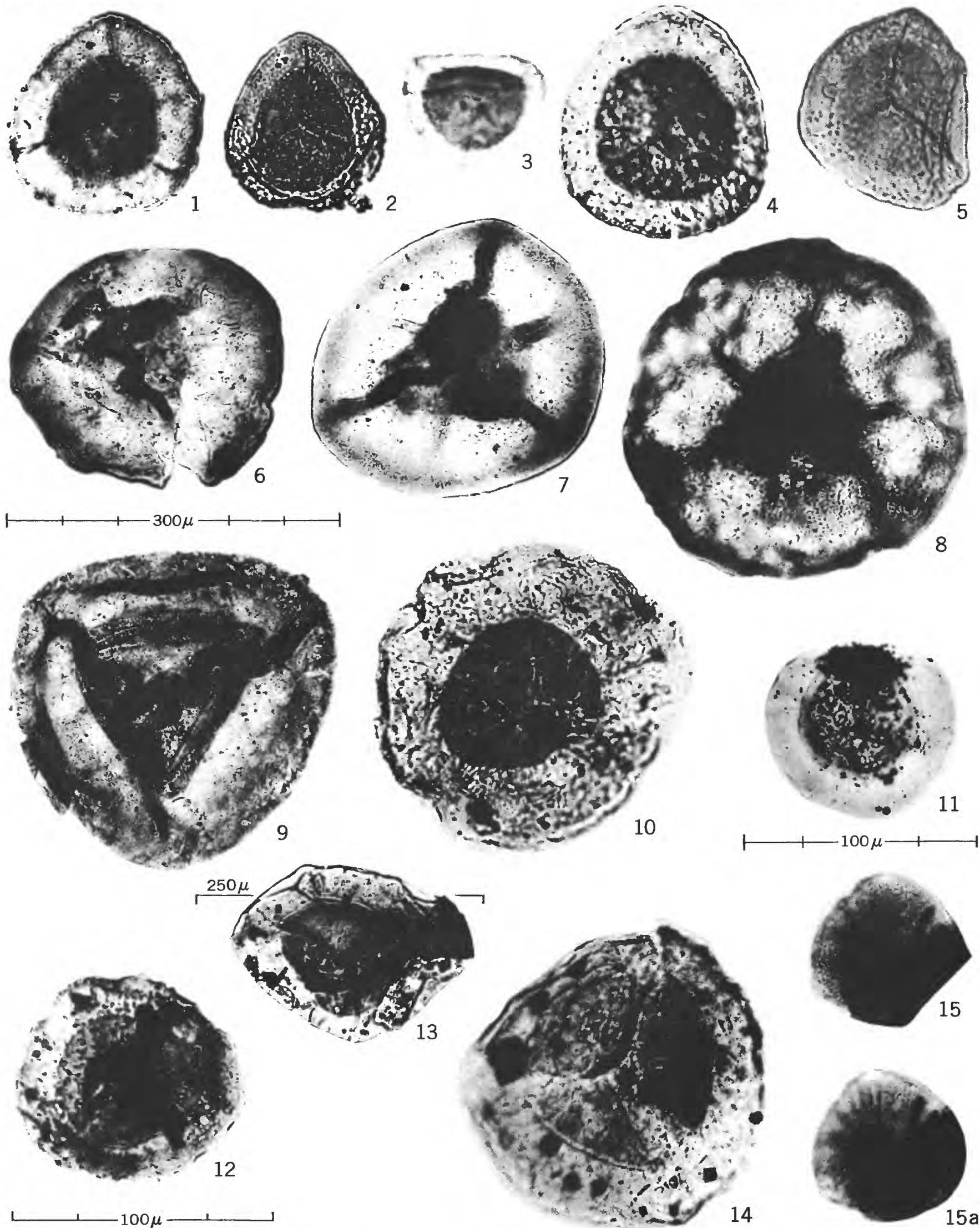

$593123 \mathrm{O}-62-12$

ENDOSPORITES, GRANDISPORA, AND RADFORTHIA N. GEN. 


\section{PLATE 17}

Figures 1-3. Calamospora obtecta? (p. 57).

[All photographs by transmitted light]

1. Specimen $52 \mu$ in maximum diameter, showing smooth coat, about $1 \mu$ thick, compressed into arcuate folds. Photographed with a blue-green filter. Scale indicated. Berea sandstone, loc. 5, maceration 153, slide 5, colln. 1-11-14-53.

2. Folded specimen $55 \mu$ in maximum diameter. See fig. 7 for scale. Berea sandstone, loc. 5 , maceration 153 , slide 23, colln. 1-11-14-53.

3. Specimen $61.3 \mu$ in maximum diameter, showing trilete rays $17 \mu$ long. Safranin stained. See fig. 1 for scale. Berea sandstone, loc. 5, maceration 153, slide 21, colln. 1-11-14-53.

4, 5. Calamospora obtecta n. sp. (p. 56).

4. Broken specimen about $66 \mu$ in minimum diameter, showing exosporal coat $1.7_{\mu}$ thick, enclosed in very thin (perisporal?) envelope. Outer membrane forms irregularly developed wrinkles or folds about $2.3 \mu$ high. See figs. 19 and 26 for scale. Berea sandstone, loc. 5, maceration 153, slide 21, colln. 1-11-14-53.

5. Holotype $66 \mu$ in maximum diameter including outer membrane. Trilete rays are about $20 \mu$ long. Outer membrane folds are up to $3.5 \mu$ in height. See fig. 7 for scale. Berea sandstone, loc. 5 , maceration 153 , slide 22 , colln. 1-11-14-53.

6. Calamospora obtecta? (p. 57).

Specimen $66 \mu$ in maximum diameter. Trilete rays are about $18 \mu$ long. Safranin stained. Photographed with a blue-green filter. See figs. 19 and 26 for scale. Bedford shale, loc. 2, maceration 161, slide 14, colln. 8-12-6-53.

7, 8. Calamospora obtecta n. sp. (p. 56).

7. Large specimen $75 \mu$ in maximum diameter, showing spore obliquely compressed, with outer membrane as much as $1.7 \mu$ in height. Scale indicated. Berea sandstone, loc. 5, maceration 153, slide 27, colln. 1-11-14-53.

8. Specimen $66.5 \mu$ in maximum diameter. Trilete rays are distinct, $19 \mu$ long. Scale indicated. Berea sandstone, loc. 5, maceration 153 , slide 25 , colln. 1-11-14-53.

9. Calamospora sp. A (p. 57).

Specimen $95.5 \mu$ in maximum diameter, showing spore coat $2.7 \mu$ thick, compressed into several lunate folds. See figs. 19 and 26 for scale. Bedford shale, loc. 2, maceration 161, slide 16, colln. 8-12-6-53.

10-12. Triletes spp. (p. 39).

10. Specimen about $320 \mu$ in maximum diameter, showing trilete rays, distinct for about $32 \mu$ and continuing as faintlines to about $140 \mu$. Spore coat about $4 \mu$ thick with a small darkened area at the apex. Scale indicated. Bedford shale, loc. 1, maceration 162, slide 3, colln. 17-12-6-53.

11. Specimen $470 \mu$ in maximum diameter. Spore coat is $4.4 \mu$ thick. Trilete rays are at least $129 \mu$ long with lips as much as $14 \mu$ in height. See fig. 10 for scale. Bedford shale, loc. 2, maceration 163, slide 8, colln. 9-12-6-53.

12. Specimen about $280 \mu$ in maximum diameter with spore coat $6.7 \mu$ thick, showing sutures slightly open and surrounded by darkened area. Rays are at least $99 \mu$ long. Scale indicated. Bedford shale, loc. 2, maceration 161 , slide 10 , colln. 8-12-6-53.

13. Punctatisporites sp. A (p. 60).

Specimen about $63 \mu$ in diameter, showing trilete rays about $25 \mu$ long. Spore coat is $4.6 \mu$ thick. See fig. 7 for scale. Bedford shale, loc. 2, maceration 161 , slide 12 , colln. 8-12-6-53.

14. Densosporites? sp. B (p. 49).

Specimen $61.5 \mu$ in diameter, with spore coat $5.8 \mu$ thick at margin. Rays are surrounded by a triangular apical dark area. Scale indicated. Lower part of Cuyahoga formation, loc. 8, maceration 148. slide 12.

15. Punctatisporites sp. A (p. 60).

Specimen $57.7 \mu$ in diameter. See fig. 1 for scale. Cleveland member of the Ohio shale, loc. 1, maceration 157-B, slide 5, colln. 3-12-6-53-b.

16. Densosporites? sp. B (p. 49).

Specimen $59.4 \mu$ in diameter. Spore coat is apparently about $9 \mu$ thick at margin. See figures 19 and 26 for scale. Bedford shale, loc. 1, maceration 162, slide 4, colln. 17-12-6-53.

17. Punctatisporites cf. $P$. nitidus Hoffmeister, Staplin, and Malloy (p. 60).

Specimen $32.7 \mu$ in diameter. Spore coat is $2 \mu$ thick. See figs. 19 and 26 for scale. Bedford shale, loc. 2 , maceration 159, slide 12, colln. 7-12-6-53-b.

18. Densosporites? sp. B (p. 49).

Specimen about $50 \mu$ in diameter (tilted in balsam mount). Spore coat at edge ranges from $5.4 \mu$ to $8.8 \mu$ in thickness and shows an apical triangular darkened area. Safranin stained. See figs. 19 and 26 for scale. Bedford shale, loc. 2 , maceration 159 , slide 13 , colln. 7-12-6-53-b. 


\section{PLATE 17-Continued}

Frgure 19. Punctatisporites sp. B (p. 61).

Specimen about $51 \mu$ in diameter with spore eoat $2 \mu$ thick. Trilete rays are $19_{\mu}$ long. Scale indicated. Logan formation, loc. 7, maceration 361 , slide 1 .

20-22. Convolutispora tuberosa n. sp. (p. 71).

20. Specimen badly abraded, $105 \mu$ in diameter including ornamentation. See fig. 14 for scale. Lower part of Cuyahoga formation, loc. 8 , maceration 148 , slide 9 .

21. Holotype $84 \mu$ in maximum diameter, showing irregular ridges as much as $11.3 \mu$ in height. The flattened tuberculate processes extend from $10 \mu$ to $16 \mu$ in width along the ridges. Scale indicated. Bedford shale, loc. 1 , maceration 162 , slide 8 , coll. 17-12-6-53.

22. Specimen obliquely compressed, $74 \mu$ in diameter, showing only 2 of the 3 trilete rays, each about $33 \mu$ long, at the margin of the spore at upper left. Partly anastomosing ridges are as much as $11 \mu$ in height. Scale indicated. Bedford shale, loc. 1, maceration 160, slide 6, colln. 15-12-6-53.

23. Verrucosisporites? sp. A (p. 63).

Specimen including ornamentation, $51 \mu$ in diameter. See figs. 19 and 26 for scale. Bedford shale, loc. 1 , maceration 162 , slide 8 , colln. 17-12-6-53.

24, 25. Convolutispora sp. A (p. 71).

24. Specimen $74 \mu$ in maximum diameter, showing convolute, partly anastomosing ridges as much as $4.8 \mu$ in height and $4 \mu$ in width. See fig. 22 for scale. Bedford shale, loc. 1, maceration 162 , slide 5 , colln. 17-12-6-53.

25. Specimen $90 \mu$ in maximum diameter with ridges as much as $6.7 \mu$ in height. See fig. 14 for scale. Lower part of Cuyahoga formation, loc. 8, maceration 148, slide 9.

26. Convolutispora sp. (p. 72).

Specimen about $120 \mu$ in maximum diameter. Scale indicated. Bedford shale, loc. 2, maceration 163, slide 7, colln. 9-12-6-53. 


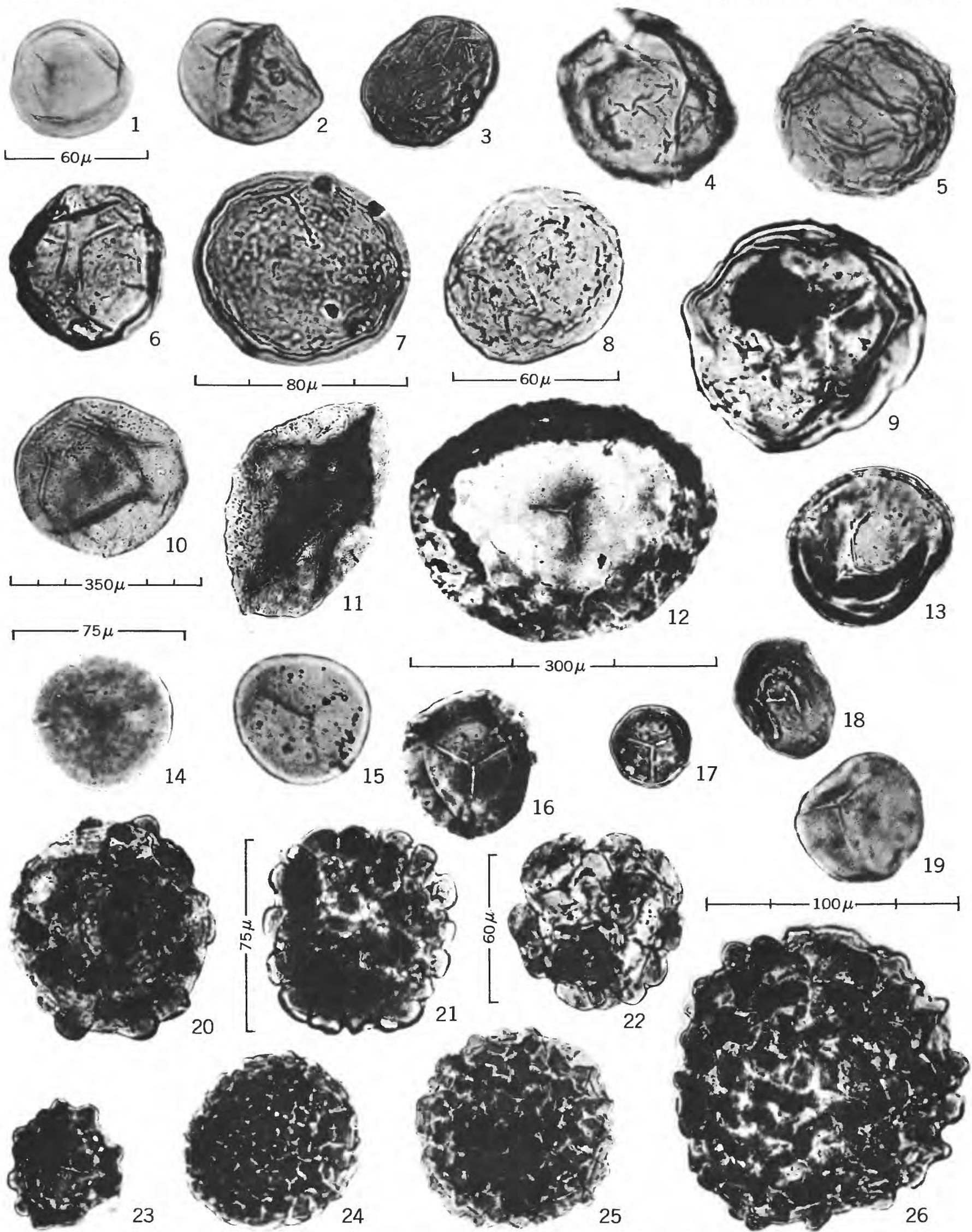

CALAMOSPORA, TRILETES, PUNCTATISPORITES, DENSOSPORITES?, CONVOLUTISPORA, AND VERRUCOSISPORITES? 


\section{PLATE 18}

Figures 1, 2. Cirratriradites sp. A (p. 42).

[All photographs by transmitted light]

1. Specimen $78 \mu$ in diameter, including obscurely demarcated flange, proximodistally compressed. See fig. 13 for scale. Bedford shale, loc. 1, maceration 40A, slide 12, colln. 4-11-1-52.

2. Specimen about $61 \mu$ in diameter, obliquely compressed with flange $12 \mu$ wide (see upper part of figure), showing distal spines up to $12 \mu$ in length and $6 \mu$ in diameter. See figs. 16 and 20 for scale. Uppermost part of Chagrin shale, loc. 1 , maceration 154 , slide 3 , colln. 10-12-6-53.

3-4a. Lycospora? sp. A (p. 40).

Safranin stained. Berea sandstone, loc. 5, maceration 153, slide 21, colln. 1-11-14-53.

3. Specimen about $45 \mu$ in diameter, distal side up. Focal plane is at distal surface. Distal spines appear as dark circles as much as $2.7 \mu$ in diameter. See fig. 13 for scale.

3a. Same specimen, focal plane lower at flange margin, showing trilete structures. Flange is about $4.5 \mu$ wide. See fig. 13 for scale.

4. Specimen about $42 \mu$ in diameter, distal side up, focal plane at level of flange. Flange is $4.2 \mu$ in width. Scale indicated.

4a. Same specimen, focal plane at distal surface, showing spine bases about $2.5 \mu$ in diameter. Scale indicated.

5. Cirratriradites hystricosus n. sp. (p. 41).

Holotype $61 \mu$ in diameter, showing dark robust distal spines as much as $4.8 \mu$ in length and $2.3 \mu$ in diameter. See fig. 7 for scale. Bedford shale, loc. 1, maceration 162, slide 10, colln. 17-12-6-53.

6. Cirratriradites sp. B (p. 42).

Specimen $75 \mu$ in diameter with flange $9 \mu-10 \mu$ wide and prominent ornamentation. See figs. 16 and 20 for scale. Bedford shale, loc. 2, maceration 159, slide 15, colln. 7-12-6-53-b.

7-11. Endosporites? crassaspinosus n. sp. (p. 47).

7. Specimen $122 \mu$ in diameter. Heavy rays extend nearly to bladder margin. Scale indicated. Bedford shale, loc. 2 , maceration 161 , slide 16 , colln. 8-12-6-53.

8. Specimen $186 \mu$ in diameter, showing rays becoming slightly sinuous toward apex and poorly preserved spines. See fig. 10 for scale. Bedford shale, loc. 2, maceration 163, slide.A, colln. 9-12-6-53.

9. Broken specimen originally about $220 \mu$ in diameter, with distal wall of bladder partly torn away, revealing inner surface of proximal coat. Broken spines average $8 \mu-9 \mu$ in diameter. Scale indicated. Bedford shale, loc. 1 , maceration $40 \mathrm{~B}$, slide 18 , colln. 4-11-1-52.

10. Holotype $194 \mu$ in diameter, distal surface up. Spore body is $107 \mu$ in diameter. Scale indicated. Bedford shale, loc. 2, maceration 163 , slide A, colln. 9-12-6-53.

11. Specimen $171 \mu$ in diameter. Trilete rays lack strong labial differentiation. See fig. 9 for scale. Bedford shale, loc. 1, maceration 40B, slide 5, colln. 4-11-1-52.

12. Cirratriradites sp. B (p. 42).

Specimen $82 \mu$ in diameter, distal surface up, showing irregular distal ridges as much as $5 \mu$ in length. Safranin stained. Scale indicated. Bedford shale, loc. 2, maceration 159, slide 14, colln. 7-12-6-53-b.

13. Spore type D (p. 73).

Specimen about $103 \mu$ in diameter, obliquely compressed, showing part of proximal surface at upper edge. Scale indicated. Bedford shale, loc. 1, maceration 40A, slide 12, colln. 4-11-1-52.

14. Verrucosisporites sp. (p. 63).

Specimen $51_{\mu}$ in diameter. See fig. 13 for scale. Bedford shale, loc. 2 , maceration 161, slide 1. colln. 8-12-6-53.

15. Anapiculatisporites? retusus n. sp. (p. 63).

Holotype $81 \mu$ in maximum diameter, proximodistally compressed, distal side up. Tubercles, $3.6 \mu$ long and $4.2 \mu$ wide, are most densely set at distal pole. Safranin stained. Scale indicated. Bedford shale, loc. 2, maceration 159, slide 12 , colln. 7-12-6-53-b.

16. Punctatisporites? sp. C (p. 61).

Specimen about $74 \mu$ in diameter, showing proximal surface set with small $(1.5 \times 2.1 \mu)$ apiculi. Safranin stained. Scale indicated. Berea sandstone, locality 5, maceration 153, slide 21, colln. 1-11-14-53.

17-19. Punctatisporites? logani n. sp. (p. 61).

See fig. 13 for scale. Logan formation, loc. 7, maceration 361, slide 2.

17. Specimen $55 \mu$ in diameter. Lips, about $3 \mu$ high, extend nearly to margin. Apiculi show on distal surfaces.

18. Specimen $75 \mu$ in diameter with rounded triangular outline.

19. Holotype $65 \mu$ in diameter with corners of spore turned typically upward toward proximal pole. Apiculi appear larger and more closely spaced towards distal pole.

20. Anapiculatisporites? retusus n. sp. (p. 63).

Specimen $76 \mu$ in diameter. Trilete rays are distinct, $31 \mu$ long. Blocky tubercles are slightly smaller than those shown in fig. 15. Safranin stained. Scale indicated. Berea sandstone, loc. 5, maceration 153, slide 22, colln. 1-11-14-53. 

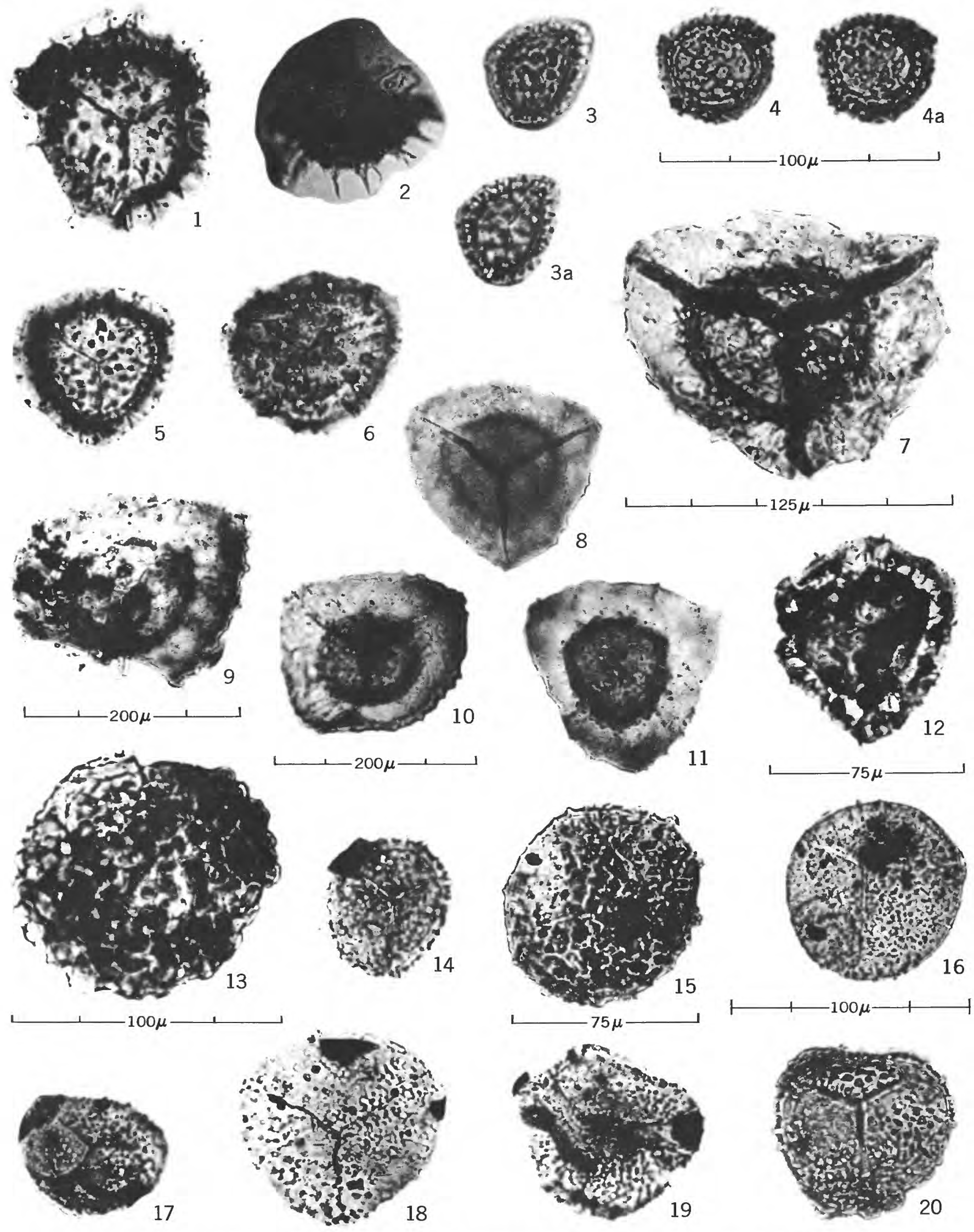

CIRRATRIRADITES, LYCOSPORA ?, ENDOSPORITES?, VERRUCOSISPORITES, ANAPICULATISPORITES?, AND PUNCTATISPORITES? 


\section{PLATE 19}

[All photographs by transmitted light]

FigURE 1. Hystrichosphaeridium ohioensis n. sp. (p. 77).

Specimen $69 \mu$ in diameter with no indication of any haptotypic structure. Spinose wall is $1.8 \mu$ thick and shows a few lunate folds. Scale indicated. Bedford shale, loc. 2, maceration 163, slide 11, colln. 9-12-6-53.

2. Canthospora? sp. (p. 70).

Specimen $100 \mu$ in diameter, showing irregular cingulum, $5 \mu-18.2 \mu$ wide, marked by several concentric lines. Trilete rays are bordered by low lips. See fig. 1 for scale. Bedford shale, loc. 2, maceration 163, slide 7, colln. 9-12-6-53. 3, 3a. Hystrichosphaeridium cf. H. longispinosum (Eisenack) Eisenack (p. 76).

Scale indicated. Uppermost part of Chagrin shale, loc. 1, maceration 154, slide 1, colln. 10-12-6-53.

3. Specimen, excluding spines, about $30 \mu$ in diameter. Plane of focus is near the center of microfossil.

3a. Same specimen photographed at lower plane of focus, showing smaller spines and circular fold in membranous wall. Black areas are mineral matter. Fourteen spines can be counted.

4. Endosporites? crassaspinosus? (p. 48).

Specimen $163 \mu$ in diameter, distal side up, showing prominent rays terminated by long spines. Distal spines are $17 \mu-35 \mu$ in length, $6.7 \mu-9.2 \mu$ in diameter. Spore possesses a continouus inner membrane about $1 \mu$ thick that is inconspicuous in photograph. Scale indicated. Bedford shale, loc. 1, maceration 40C, slide 28, colln. 4-11-1-52.

5. Spore type A (p. 73).

Specimen $95 \mu$ in diameter with broad irregular cingulum. See fig. 1 for scale. Bedford shale, loc. 1, maceration 40C, slide 26, colln. 4-11-1-52.

6. Spore type B (p 73).

Spore $44 \mu$ in diameter. Apical dark area is caused by highly developed lips. Scale indicated. Bedford shale, loc. 1, maceration 160, slide 6 , colln. 15-12-6-53.

7. Verrucosisporites depressus n. sp. (p. 63).

Holotype $65 \mu$ in greatest diameter, showing trilete rays about $18 \mu$ long and spore coat $1.3 \mu$ thick with closely set minute tubercles, $0.7 \mu$ high and $2 \mu-2.3 \mu$ in diameter. Note inverse reticulate pattern. Safranin stained. Scale indicated. Basal part of Sunbury shale, loc. 9, maceration 151-3, slide 6, colln. 2-5-3-53.

8. Spore type C (p. 73).

Tetrad of spores, each about $100 \mu$ in diameter. See figs. 4 and 9 for scale. Bedford shale, loc. 1, maceration $40 \mathrm{~B}$, slide 10, colln. 4-11-1-52.

9, 9a. Triletes sp. (p. 39).

Bedford shale, loc. 2, maceration 159, slide 10, colln. 7-12-6-53-b.

9. Unique specimen $290 \mu$ in diameter, proximal side up. Rays are about $8 \mu$ wide. Scale indicated.

9a. Sector from same specimen at higher magnification showing densely packed tubercles, about $10 \mu$ long and $4 \mu-12 \mu$ in diameter, producing an inverse reticulate appearance. The contact surfaces are thin and smooth. See figs. 3 and 3 a for scale.

10. Triletes sp. A (p. 38).

Specimen $340 \mu$ in diameter, proximodistally compressed, showing conspicuous contact areas and rugose spore coat. See figs. 4 and 9 for scale. Bedford shale, loc. 1, maceration 40C, slide 5, colln. 4-11-1-52.

11. Triletes sp. (p. 39).

Unique specimen $585 \mu$ in maximum diameter with smooth spore coat about $17 \mu$ thick. Scale indicated. Basal part of Bedford shale, loc. 1, maceration 61-1, slide 16, colln. 5-5-23-53.

12. Callixylon sp. (p. 64)

Specimen consisting of two secondary tracheids and a group of ray cells showing the groups of bordered pits. Scale indicated. Upper part of Bedford shale, loc. 3, maceration 306, slide 6, colln. 2-11-14-53.

13. Unidentified vascular tissue. (p. 65).

Specimen consisting of a few tracheids with more uniformly dispersed multiseriate bordered pitting. See figs. 4 and 9 for scale. Berea sandstone, loc. 5, maceration 153, slide 28, colln. 1-11-14-53. 

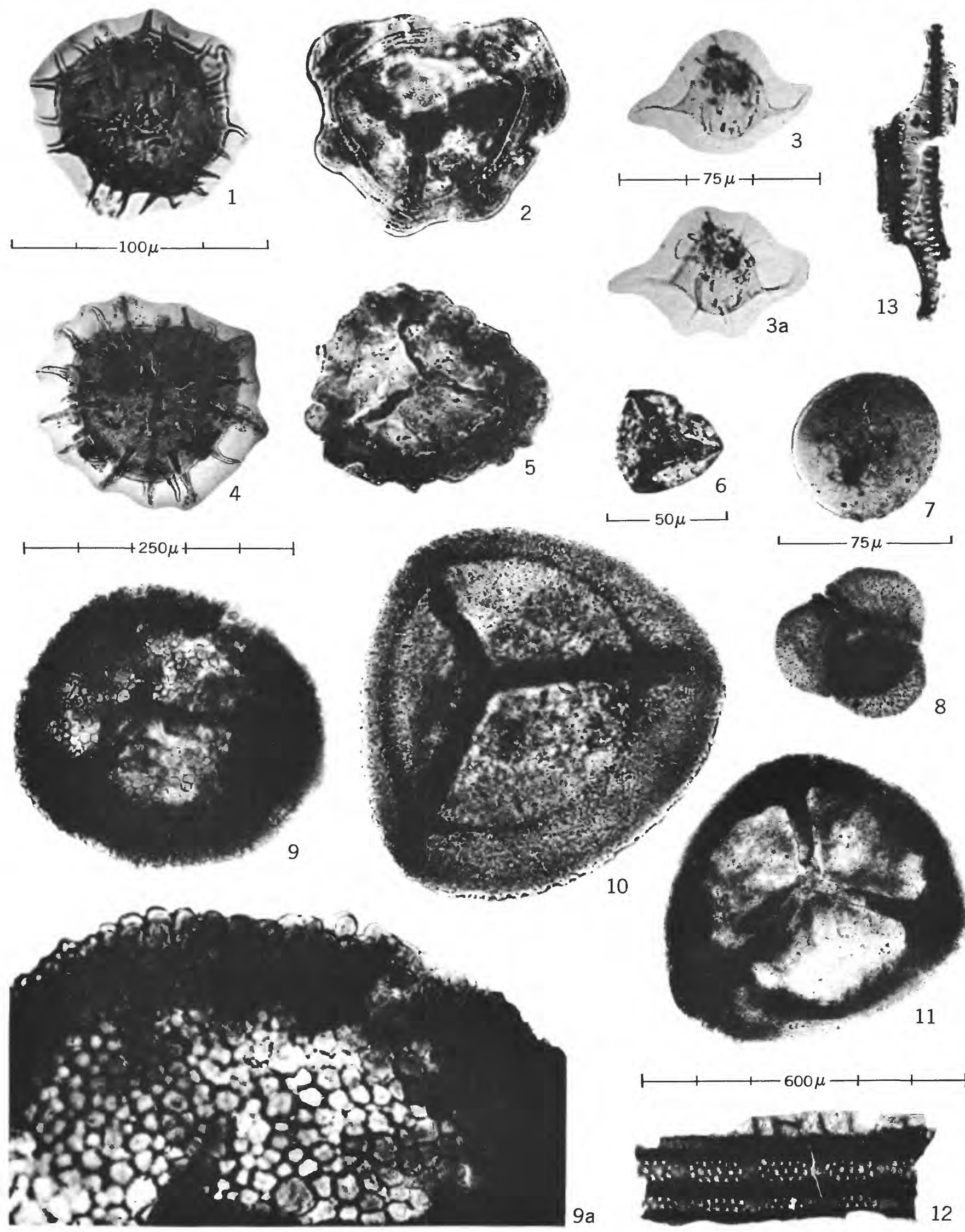

HYSTRICHOSPHAERIDIUM, CANTHOSPORA?, ENDOSPORITES?, VERRUCOSISPORITES, TRILETES, AND CALLIXYLON 


\section{PLATE 20}

[All photographs by transmitted light]

Figures 1-3. Tasmanites sinuosus n. sp. (p. 83).

1. Holotype $170 \mu$ in maximum diameter. Wall is about $5 \mu$ thick with numerous puncta (p), characteristically folded. Scale indicated. Basal part of Cleveland member of the Ohio shale, loc. 1, maceration 156, slide 1, colln. 1-12-6-53.

2. Specimen $134 \mu$ in diameter. Wall is $4 \mu-5 \mu$ thick. Scale indicated. Basal part of Cleveland member of the Ohio shale, loc. 2, maceration 155 , slide 2, coll. 4-12-6-53.

3. Specimen $128 \mu$ in diameter. Wall is $4 \mu$ thick. Specimen is filled with pyrite and still spherical. A few puncta (p) are visible. See figs. 1 and 2 for scale. Basal part of Cleveland member of the Ohio shale, loc. 1, maceration 156, slide 2, colln. 1-12-6-53.

4, 4a. Tasmanites sommeri n. sp. (p. 84).

See fig. 9 for scale. Lowermost part of Ohio shale, loc. 7, maceration 378, slide 3.

4. Sector of holotype specimen showing conspicuous puncta. Photographed with ordinary light.

4a. Same specimen, about $500 \mu$ in diameter. Wall thickness, concentric laminations of wall, and puncta more conspicuous as photographed with polarized light.

5, 6. Tasmanites sp. A (p. 85).

Photographed with a blue-green filter. See fig. 7 for scale. Olentangy shale, loc. 8, unmacerated black shale, colln. 606-1774-1784.

5. Specimen $173 \mu$ in diameter. Wall is about $25 \mu$ thick. Numerous puncta appear as black dots.

6. Specimen $180 \mu$ in diameter. Wall is $25 \mu$ thick. Central portion shows inner openings of puncta.

7. Tasmanites sp. A? (p. 85).

Specimen about $220 \mu$ in diameter. Wall is about $14 \mu$ thick. Photographed by polarized light. The appearance of some of the numerous puncta as bright points and darker areas is the result of the anisotropic effect. Black spots are pyrite crystals. Compare with pl. 20, fig. $4 \mathrm{a}$ and pl. 21, fig. 2. Scale indicated. Bedford shale, loc. 1 , maceration 40C, slide 3, colln. 4-11-1-52.

8, 8a. Tasmanites sp. (p. 85)

See figure 9 for scale. Basal part of Bedford shale, loc. 1, maceration 61-1, slide 8, colln. 5-5-23-53.

8. Extremely large specimen $810 \mu$ in diameter. Wall is $68 \mu$ thick with numerous puncta appearing as black dots. Focal plane at upper surface of wall. Specimen photographed centered over strong beam of light.

8a. Sector of same specimen, showing wall in optical section.

9. Tasmanites sommeri? (p. 84).

Specimen $370 \mu$ in diameter. Wall is $40 \mu$ thick. A few puncta appear as minute black dots. Scale indicated. Bedford shale, loc. 2, maceration 159, slide 1, colln. 7-12-6-53-b. 


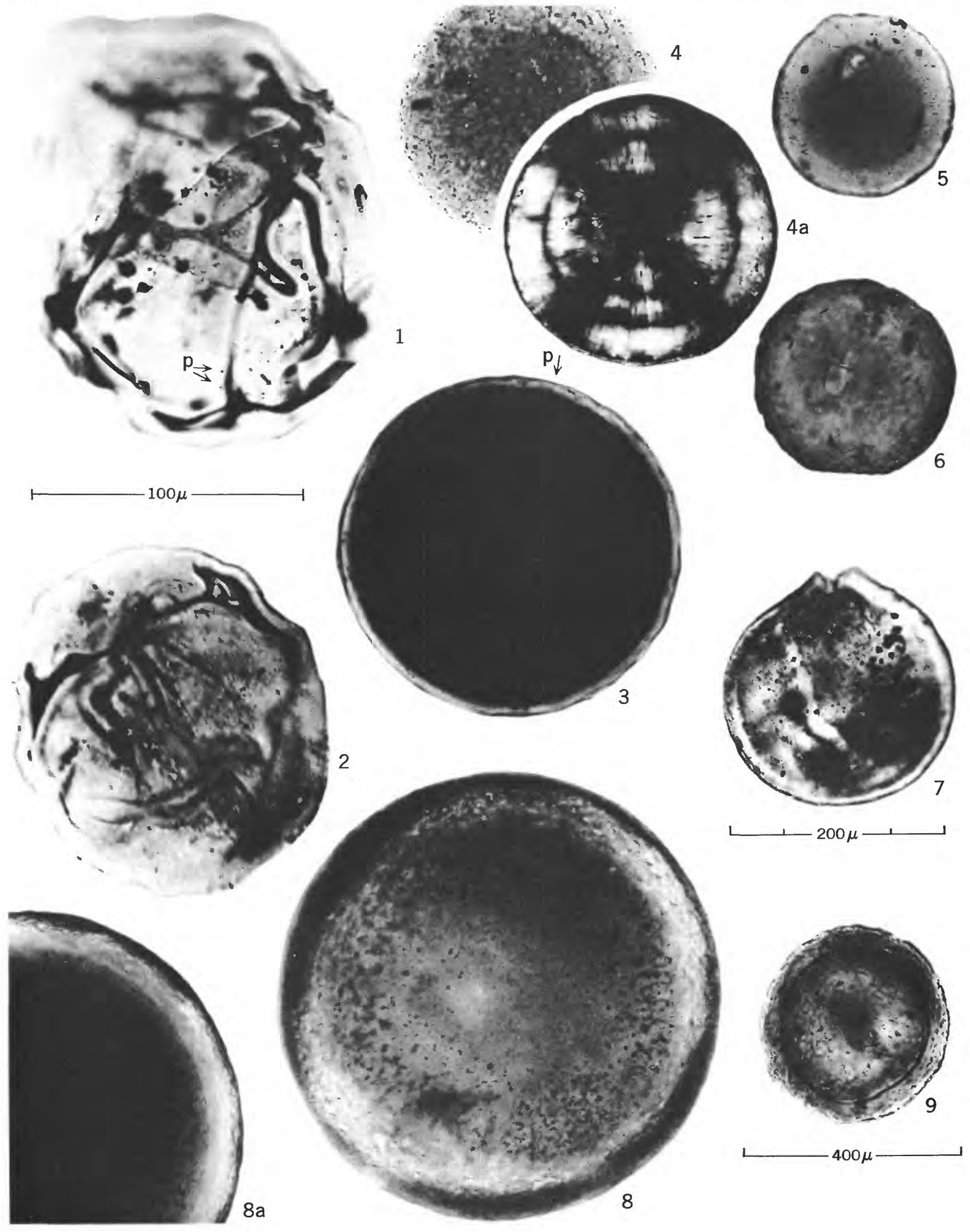




\section{PLATE 21}

\section{[All photographs by transmitted light]}

Figures 1, 1a. Tasmanites huronensis (Dawson) S. W. \& B., emend. Winslow (p. 81).

Pleistocene till, Iroquois County, Ill., slide CL-1.

1. Specimen $250 \mu$ in diameter. Wall is $21 \mu$ thick. Puncta conspicuous, spaced $15 \mu-18 \mu$ apart. The coat is split open and edges turned outward, thus permitting a much closer study of punctum configuration than is possible in unbroken specimens. Scale indicated.

1a. Same specimen photographed at high magnification, showing detail of funnel-shaped internal openings of puncta. The apparent widening toward the external opening is only an optical effect. Scale indicated.

2. Tasmanites sommeri n. sp. (p. 84.)

Specimen $400 \mu$ in diameter, photographed by polarized light, showing numerous puncta and undulatory extinction. Wall is $40 \mu$ thick. See fig. 1 for scale. Lowermost part of Ohio shale, loc. 6, maceration 451, slide 1.

3. Spermatites sp. (p. 65).

Specimen $2.2 \mathrm{~mm}$ long, probably representing a gymnospermous megaspore membrane. Surfaces are abraded and not well preserved. Scale indicated. Bedford shale, loc. 2, unmacerated siltstone and shale (same sample as maceration 163), colln. 9-12-6-53.

4-5a. Sclerenchymatous "nests" (p. 73).

4. Specimen about $630 \mu$ in diameter. Cell lumens are $38 \mu-58 \mu$ in diameter. See fig. 5 for scale. Berea sandstone, loc. 5, maceration 153, slide 18, colln. 1-11-14-53.

5. Sclerenchymatous "nest" with attached cuticular membrane and central area about $300 \mu$ in diameter. Scale indicated. Upper part of Bedford shale, loc. 3, Maceration 306, slide 5, colln. 2-11-14-53.

5a. Same specimen photographed at higher magnification, showing central sclerenchymatous tissue. Cell lumens are $20 \mu-36 \mu$ in diameter; walls are $6 \mu-8 \mu$ thick. Scale indicated. 


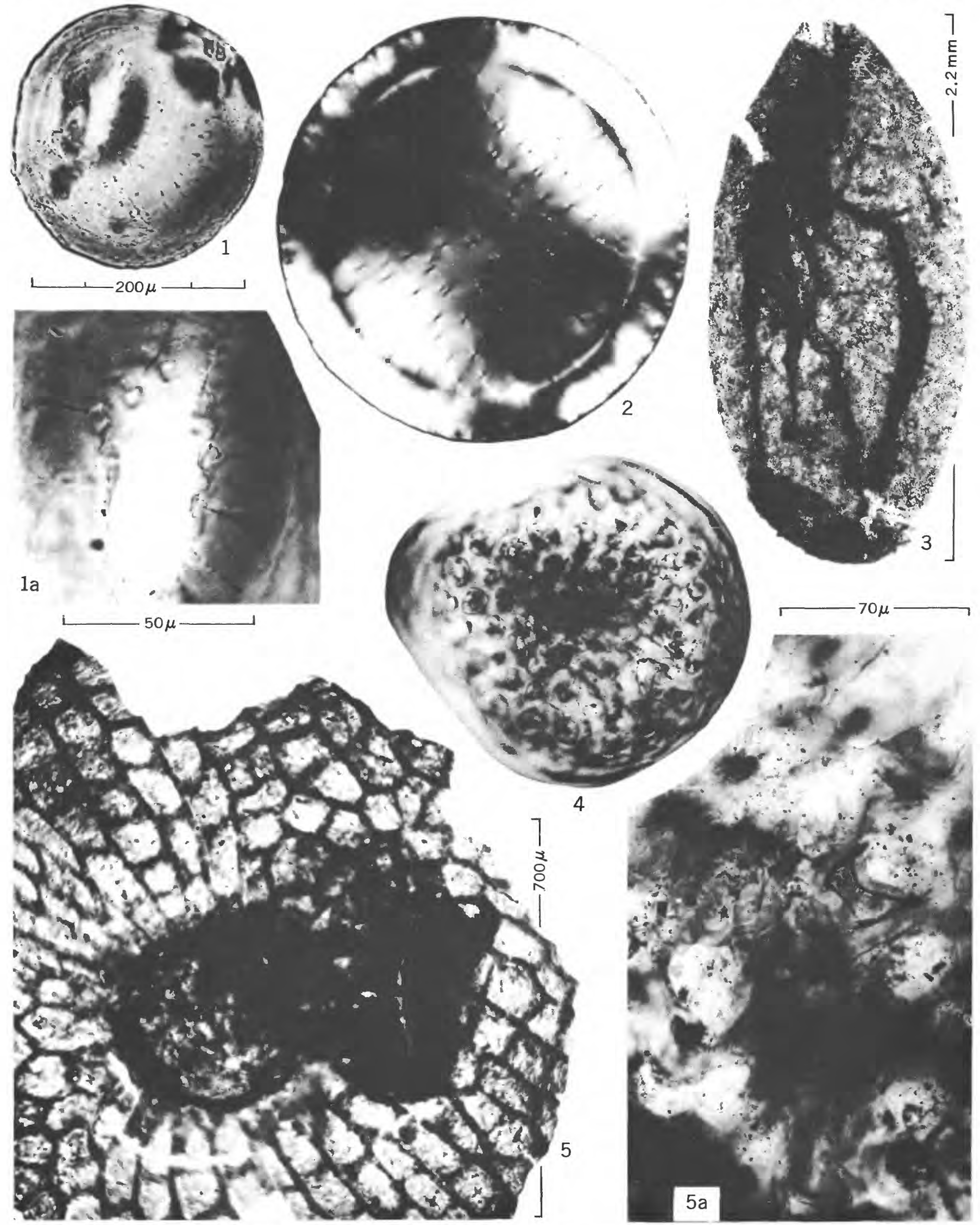

$5931230-62-13$ 


\section{PLATE 22}

[Camera lucida drawings by transmitted light]

Figures 1-4. Hystrichosphaeridium trispinosum Eisenack (p. 75).

See figs. 5,6 , and 11 for scale.

1. Rather large specimen; body $25 \mu$ in diameter, filled with pyrite. Hollow spines are about $35 \mu$ long. Upper part of Cleveland member of the Ohio shale, loc. 6 , maceration 440 , slide 3 .

2. Specimen obliquely tilted in balsam mount showing flattened profile. Lowermost part of Chagrin shale, loc. 8 , maceration 394 , slide 6 .

3. Specimen slightly tilted in balsam mount so that spine at upper left appears foreshortened. All spines are about $20 \mu$ long. Dark central spot is pyrite. Upper part of Huron member of the Ohio shale, loc. 6, maceration 448 , slide 12 .

4. Smallest specimen observed; body $13 \mu-14 \mu$ in diameter, filled with pyrite. Spines are about $8 \mu$ long. Lowermost part of Chagrin shale, loc. 8 , maceration 394 , slide 6 .

5-7. Hystrichosphaeridium cf. H. longispinosum (Eisenack) Eisenack (p. 76).

Scale indicated below figs. 5 and 6 . Major spines indicated by arrows.

5. Well-preserved specimen, $32 \mu$ in diameter (excluding spines). Chagrin shale, loc. 6 , maceration 446 , slide 3.

6. Specimen about $32 \mu$ in maximum diameter with 18 spines. Lowermost part of Chagrin shale, loc. 8 , maceration 394 , slide 6 .

7. Specimen about $33 \mu$ in diameter with 26 spines, $22 \mu-26 \mu$ long. Chagrin shale, loc. 6 , maceration 446 , slide 8 .

8. Micrhystridium sp. A (p. 77).

Specimen about $19 \mu$ in diameter with about 30 spines, $4 \mu-5 \mu$ long. The membranous wall appears brilliant yellow by transmitted light and is less than $0.5 \mu$ thick. See figs. 5, 6, and 11 for scale. Upper part of Huron member of the Ohio shale, loc. 6 , maceration 448 , slide 7 .

9. Hystrichosphaeridium ohioensis n. sp. (p. 77).

Holotype about $53 \mu$ in diameter, similar to that shown in fig. 8 , but larger. Note circular folds of membranous wall. Spines are $12 \mu-17 \mu$ long. See fgs. 5,6 , and 11 for scale. Chagrin shale, loc. 6 , maceration 419 , slide 5 .

10, 11. Cranulatisporites logani n. sp. (p. 62).

10. Specimen $57 \mu$ in axial length, laterally compressed, showing variation in spore coat thickness. Dashed lines indicate trilete suture on underside of specimen. See figs. 5, 6, and 11 for scale. Logan formation, loc. 7, maceration 361 , slide 2 .

11. Holotype $73 \mu$ in diameter, compressed proximodistally, proximal side up. Coat thickness and distal ornamentation indicated. Note darker area around proximal pole. Suture is indistinct at its extremities. Scale indicated. Upper part of Cuyahoga and Black Hand formations undifferentiated, loc. 7, maceration 363a, slide 4.

12. Anapiculatisporites? retusus n. sp. (p. 63).

Specimen $57 \mu \times 46 \mu$. Note irregularly blunt to pointed distal ornamentation, smooth proximal areas. See figs. 5,6 , and 11 for scale. Bedford shale, loc. 6, maceration 439 , slide 4 .

13. Densosporites sp. A (p. 49).

Specimen $36 \mu$ in diameter, distal side up. The dark margin appears $6 \mu-8 \mu$ wide and girdles the spore slightly distal to the true equator. See figs. 5, 6, and 11 for scale. Logan formation, loc. 7, maceration 361, slide 1.

14. Punctatisporites sp. B (p. 61).

Specimen about $49 \mu$ in diameter with smooth coat about $3 \mu$ thick. See figs. 5, 6, and 11 for scale. Bedford shale, loc. 6 , maceration 439 , slide 7 .

15. Dicrospora porcata n. sp. (p. 52).

Holotype $250 \mu$ in total axial length, showing body form and trilete elaboration. Scale indicated. Upper part of Bedford shale, loc. 9, maceration 319a, slide 1, colln. 2-4-23-53.

16. Dicrospora multifurcata n. sp. (p. 53).

Specimen $203 \mu$ in total axial length, compressed laterally, showing typical development of lips and hollow spines with multipartite tips. See fig. 15 for scale. Chagrin shale, loc. 8 , maceration 392 , slide 6 .

17. Radforthia radiata $\mathrm{n}$. sp. (p. 72).

Holotype $67 \mu$ in diameter, compressed proximodistally, proximal side up, showing open commissure and radiating proximal ridges. See figs. 5, 6, and 11 for scale. Upper part of Bedford shale, loc. 6, maceration 438, slide 5 . 
PLATE 22-Continued

Figures 18-20. Cyrtospora clavigera n. sp. (p. 67).

See figs. 5, 6, and 11 for scale. Cuyahoga and Black Hand formations undifferentiated, loc. 7, maceration 366, slide 3 .

18. Specimen $45 \mu$ in diameter, compressed proximodistally, smooth proximal side up. Coat thickness and extent of distal ornamentation is shown by dotted lines.

19. Holotype about $50 \mu$ in diameter. Suture is shown by dashed lines. Distal ornamentation is usually more extensive than on this specimen.

20. Specimen $53 \mu$ in axial length, compressed laterally, partially filled with mineral matter, showing typical form of internal spore cavity and thick massive distal ornamentation, somewhat abraded on this specimen.

21. Reticulatisporites? fimbriatus n. sp. (p. 58).

Holotype. Same specimen shown by photographs in figs. 1, 1a, and $1 \mathrm{~b}$ on pl. 14. Drawing shows details of the fringed narrow muri on the distal surface. Muri appear wide when flattened against spore coat. Dashed lines show position of trilete suture. See figs. 5, 6, and 11 for scale. Bedford shale, loc. 1, maceration 40B, slide 16, colln. 4-11-1-52.

22. Reticulatisporites? fimbriatus var. spathulatus n. var. (p. 59)

Holotype, distal surface up. Same specimen is shown in slightly different position by photographs in figs. 4 and $4 \mathrm{a}$ on pl. 14. Murus bordering margin of spore at left shows some fringing typical of the species and some of the spatulate processes. Part of trilete suture is indicated by dashed lines. See figures 5, 6, and 11 for scale. Bedford shale, loc. J, maceration 40B, slide 15, colln. 4-11-1-52.

23. Reticulatisporites crassus n. sp. (p. 58).

Photograph of same specimen is shown in fig. 9 on pl. 14. Specimen is oriented proximal side up with open suture. Proximal muri are present on the interradial areas and also partially border the trilete suture. See figs. 5, 6, and 11 for scale. Lower part of Cuyahoga formation, loc. 8, maceration 148, slide 13. 

GEOLOGICAL SURVEY

PROFESSIONAL PAPER 364 PLATE 22

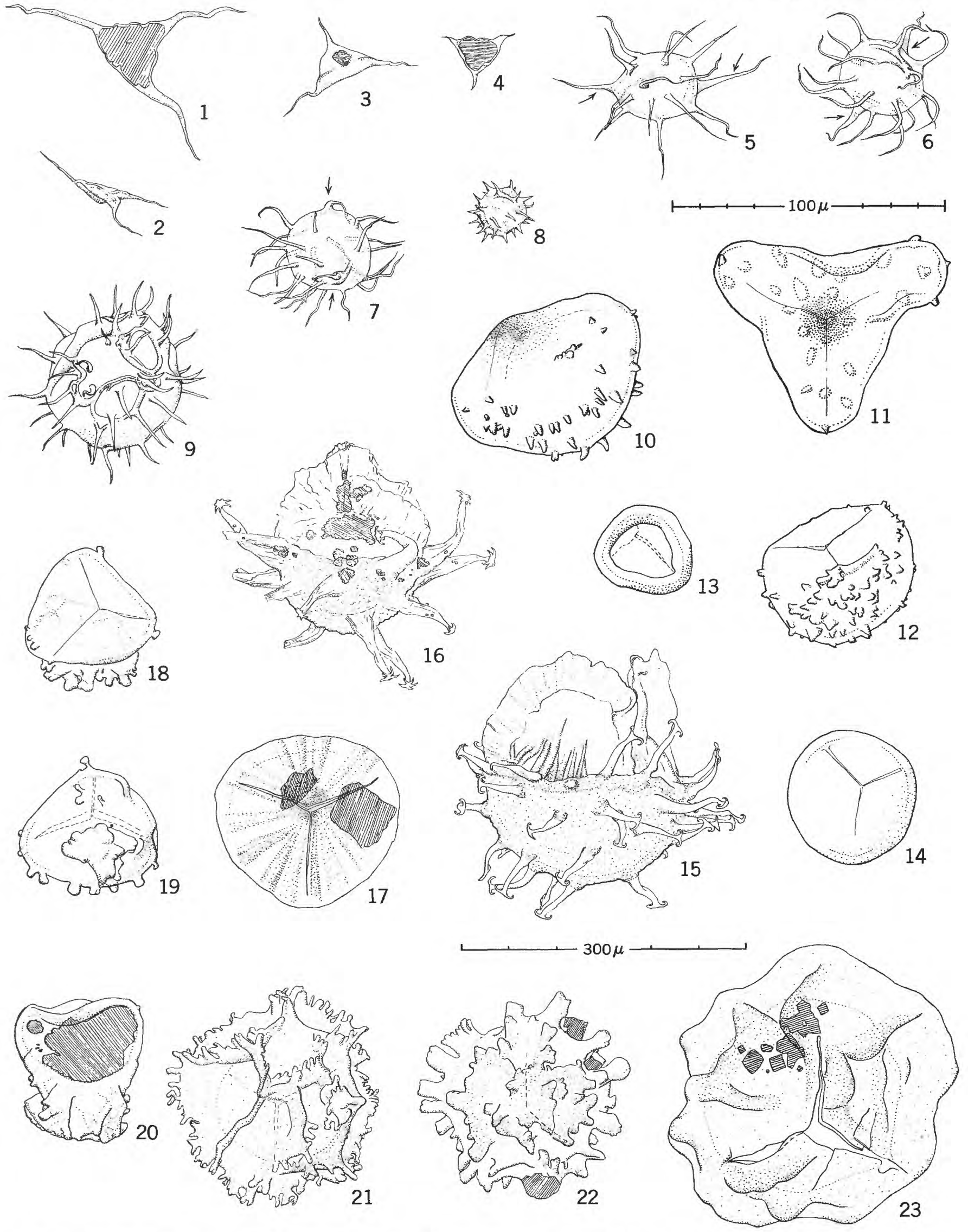

HYSTRICHOSPHAERIDIUM, MICRHYSTRIDIUM, GRANULATISPORITES, ANAPICULATISPORITES?, DENSOSPORITES, PUNCTATISPORITES, DICROSPORA, RADFORTHIA, CYRTOSPORA, AND RETICULATISPORITES 


